\title{
NEOPROTEROZOIC CARBONATE RAMP DEVELOPMENT IN THE CANADIAN ARCTIC (SHALER SUPERGROUP): SEDIMENTOLOGY, SEQUENCE STRATIGRAPHY, AND CHEMOSTRATIGRAPHY
}

\section{Danielle Thomson}

A thesis submitted to the Faculty of Graduate and Postdoctoral Affairs in partial fulfillment of the requirements for the degree of

Doctor of Philosophy

Department of Earth Sciences

Carleton University

Ottawa-Carleton Geoscience Centre

Ottawa, Ontario

February 2014

CCopyright 2014, Danielle Thomson 


\section{FRONTISPIECE}

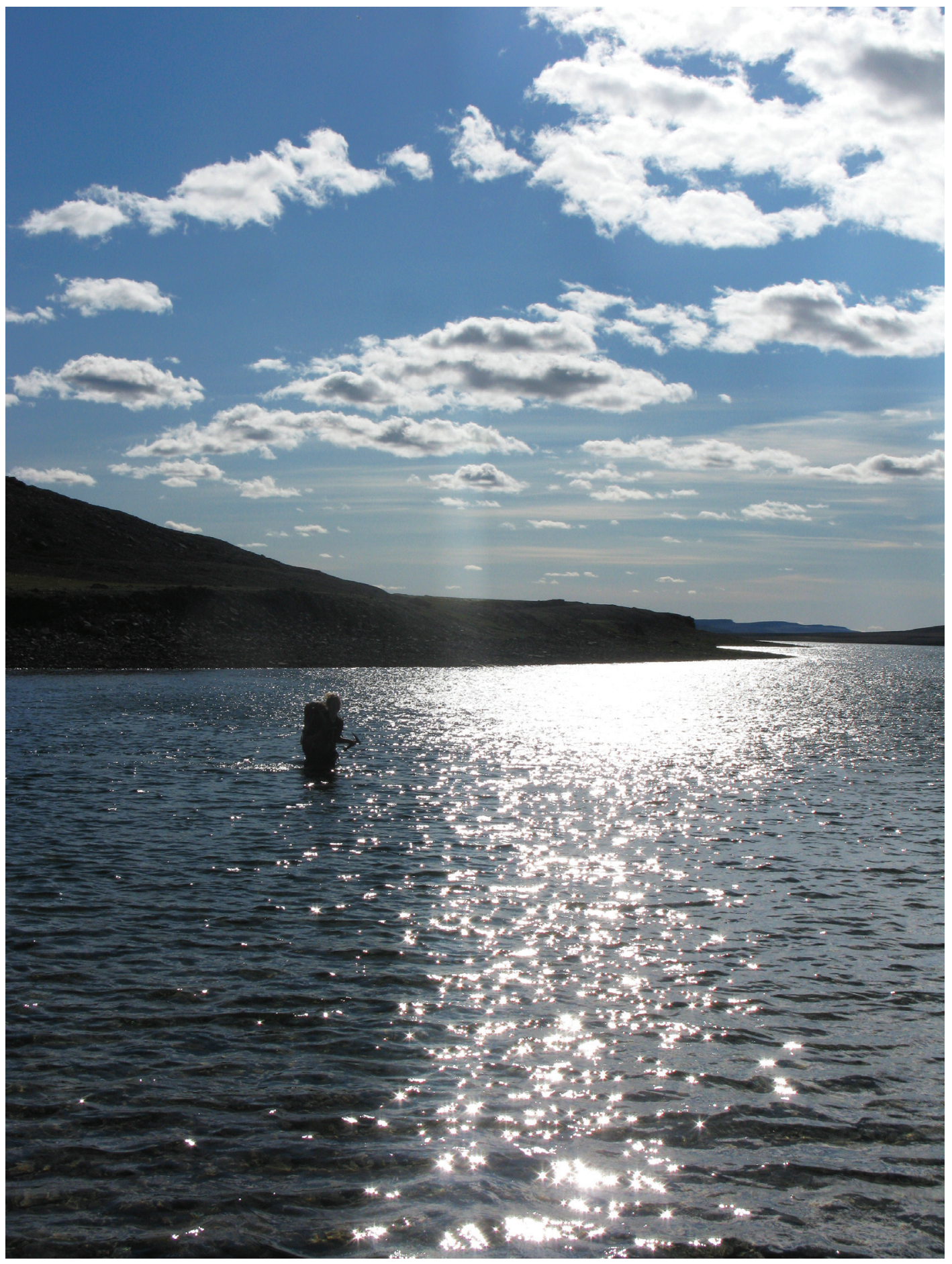

$\sim$ Evening river crossing, NW Minto Inlier 


\begin{abstract}
This study describes Tonian-Cryogenian pre-rift strata of the upper Shaler Supergroup, deposited in the Amundsen Basin (Victoria Island, Canada). The Wynniatt Formation, part of the upper Shaler Supergroup, consists of three carbonate ramp successions separated by regional unconformities. Each cycle represents part of a distally steepened, storm-dominated carbonate ramp. Temporal changes in carbonate facies record depositional environments spanning from supratidal to outer ramp settings. Interpretation of an intertidal mudflat depositional environment for the Tawuia-Chuaria assemblage zone provides depositional context for interbasinal biostratigraphic correlation. Correlation between the Amundsen and Fifteenmile (Yukon) basins is complicated by differing rates and regimes of subsidence, with the exception of a regional basin-deepening event. Contrary to previous correlations, it is proposed that the upper Shaler Supergroup and Little Dal Group of the Mackenzie Mountains Supergroup (Mackenzie Basin) are equivalent to the entire Fifteenmile Group.

Five transgressive-regressive (T-R) cycles were identified in the Jago Bay, Minto Inlet, and Wynniatt formations. Three tectonostratigraphic units for the upper Shaler Supergroup record an initial sag basin, followed by early extension and thermal doming, and finally rifting of the Amundsen Basin. Neoproterozoic successions of northwest Laurentia are an example where rift and intracontinental basins are spatially and temporally related. Subsidence possibly was related to multiple cycles of intra-plate extension that complemented coeval fault-controlled subsidence.

An improved $\delta^{13} \mathrm{C}_{\text {carb }}$ curve paired with $\delta^{13} \mathrm{C}_{\text {org }}$ values provides support for correlation of a significant negative $\delta^{13} \mathrm{C}$ excursion that has been linked to the Bitter Springs stage. In the Amundsen Basin, $\delta^{13} \mathrm{C}_{\text {carb }}$ values drop to markedly negative values $(>-14 \%$ o), which is attributed to local overprints whereby isotopically light carbon in pore waters was precipitated as authigenic carbonate cement fuelled by oxidation of methane or organic matter during sulphate and iron reduction. Redox proxies indicate local basin euxinia and anoxia. Pronounced Mo, V, and U enrichments in euxinic black shales suggest that the Bitter Springs stage was a transitional time, where the global oceans became more oxygenated relative to preceding portions of the mid-Proterozoic, but remained more reducing compared to the Phanerozoic.
\end{abstract}




\section{ACKNOWLEDGEMENTS}

This whole adventure started over beers with Rob at the Black Knight in Yellowknife, an auspicious start to a project in Canada's north, and not to mention a good way to get to know your future supervisor! I would like to thank Rob for his guidance through the past four years; he has been a constant source of wisdom, and is always present to offer his help. One could not ask for a better mentor.

Thank you to George Dix for never seeming to mind when I would pop into his office with a question, and for incredibly fast reviews of drafts. Thank you to Beth and Sheila for all your help over the years. And of course thank you to all the other students at Carleton University that I have met over the years for their help, laughter, and enthusiasm.

Thank you to all the people I had the pleasure of spending my summers with in the field, especially those who spent time helping to measure sections with me: Nicole, John, Guillaume, Trent, Matt, Durbano, Ben, Dylan, Jordan, Jean, Etienne, and Nicole R. Thank you to the cooks and pilots for keeping us safe and well fed. To Bryan Krapez and Elizabeth Turner for many helpful discussions over the rocks. Thank you to Galen Halverson for inviting Rob and I to come check out the rocks in the Yukon, truly an amazing experience, and thank you to Pierre, Marcus, and Justin for helpful discussions while up there.

To Andrey and Noah, who may not agree on everything but definitely opened my eyes to the complexities of geochemical interpretations. Thank you to Wendy Abdi and everyone in the G. G. Hatch Lab at Ottawa $U$ for their help with carbon isotope analysis.

Financial support was provided through the GSC's GEM Victoria Island program, an NSERC PGS-D award, NSTP grant, Ontario Graduate Scholarship, Mary-Claire Ward Geoscience Award, IUGS Young Scientist Foundation Award, and Carleton University departmental scholarships.

Finally, thank you to my family for all their support throughout the past few years. Lorraine and Mario thank you so much for the delicious home-cooked meals and being there when I needed your help. Mom and Dad - I could not have made the home stretch without you. Much love. 


\section{PREFACE}

\section{Method of Presentation}

This thesis is presented as five chapters: an introduction, conclusion, and three stand-alone manuscripts addressing specific geological problems. While there may be some overlap given the focused nature of this project, redundancies are generally restricted to the introductory portions of the chapters. The order of the manuscripts follows the order of publication given that later manuscripts build upon the framework provided by earlier manuscripts. At the time of this submission, chapter two is published in Sedimentary Geology (Thomson, D., Rainbird, R.H., Dix, G., 2014. Architecture of a Neoproterozoic intracratonic carbonate ramp succession: Wynniatt Formation, Amundsen Basin, Arctic Canada. Sedimentary Geology, 299: 119-138.), chapter three is re-submitted to GSA Bulletin (Thomson, D. Rainbird, R. H., Krapez, B., submitted. T-R cycles and tectonostratigraphy of the Neoproterozoic (Tonian-Cryogenian) Amundsen Basin prior to supercontinent (Rodinia) breakup), and chapter four is submitted to Precambrian Research (Thomson, D., Rainbird, R. H., Planavsky, N., Lyons, T., Bekker, A. Chemostratigraphy of the Shaler Supergroup, Victoria Island, NW Canada: a record of ocean composition prior to the Cryogenian glaciations). I am the primary author on all three contributions.

\section{Original Contribution}

The aims of this research were to formally describe the members of the Wynniatt Formation, including the nature of their bounding surfaces, lithostratigraphy, lithofacies, and depositional environments. Sequence (T-R) stratigraphic, chemostratigraphic, and geochemical studies were also undertaken for the upper Shaler Supergroup (including the Wynniatt Formation) to better understand cyclicity within the basin, mechanisms for basin subsidence, improve stratigraphic correlations, and understand seawater chemistry (C, O, S, redox proxies). This required integrating previously published data with newly acquired stratigraphic, sedimentological, and geochemical data. The choice of study areas and research objectives were my own. Fieldwork was carried out over two summers (2010 and 2011), and measurement of stratigraphic sections and sampling was done by myself, with the aid of a field assistant.

Samples collected during the summer were selected by myself for petrography and geochemical analyses. Cut samples were sent to Vancouver Petrographics and made into thin sections. I preformed the petrography at Carleton University. Rock powders for $\mathrm{C}$ and $\mathrm{O}$ isotope analyses were drilled by myself, or drilling locations were selected by myself and drilled by an assistant at Carleton University using a dental drill. Samples for $\mathrm{C}$ and $\mathrm{O}$ isotope analysis were analyzed at the G. G. Hatch Laboratory of the University 
of Ottawa, where I weighed and prepared the samples under the supervision of Wendy Abdi. I preformed SEM analyses at Carleton University under the supervision of George Dix. I prepared and ran XRF analyses for major and trace elements at the University of Ottawa under the supervision of Ron Hartree. Samples were sent to the University of Manitoba for organic C and S isotope analysis, preformed by Andrey Bekker and Misuk Yun. A subset of these samples was sent to Noah Planavsky for Fe speciation analysis, preformed in Tim Lyon's lab at the University of California, Riverside. Samples were sent to ACME Laboratories, Vancouver, for major and trace element analysis.

I drafted all figures and prepared all tables in this thesis. This thesis presents a wealth of new stratigraphic, sedimentological, and geochemical data. The models presented in this thesis represent my interpretation of these data. I prepared initial drafts of all papers, with editorial modifications suggested by co-authors. Specifically, B. Krapez provided technical expertise on intracontinental basins and sequence stratigraphy; N. Planavsky and A. Bekker provided geochemical expertise on stable isotopes and redox proxies (methods, analysis, and interpretation). Finally, I am wholly responsible for any omissions or inaccuracies in this document. 


\section{Table of Contents}

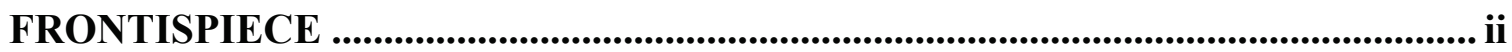

ABSTRACT .........................................................................................................................

ACKNOWLEDGEMENTS ......................................................................................... iv

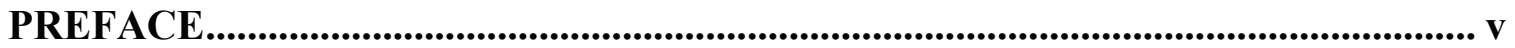

LIST OF FIGURES ................................................................................................................. $\mathrm{x}$

LIST OF TABLES ................................................................................................................ Xv

APPENDIXES ..................................................................................................................... Xvi

CHAPTER 1: INTRODUCTION............................................................................... 1

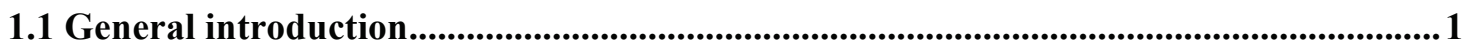

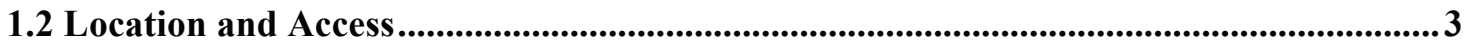

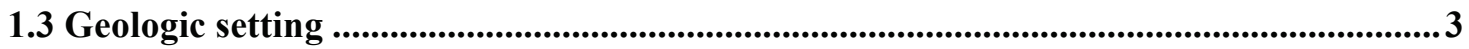

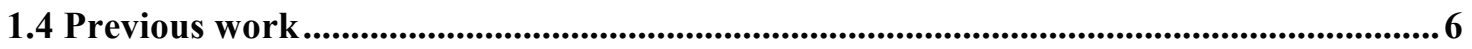

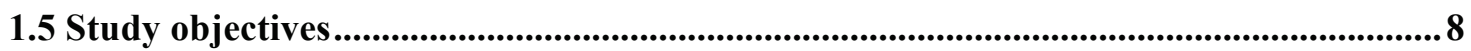

1.6 Methodology …......................................................................................................................... 10

\section{CHAPTER 2: SEDIMENTARY ARCHITECTURE OF THE WYNNIATT}

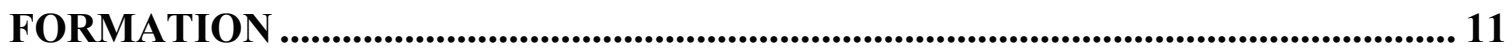

2.1 Introduction .................................................................................................................................... 11

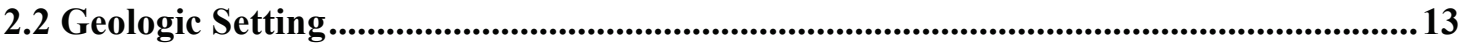

2.3 Previous Work .......................................................................................................................................... 14

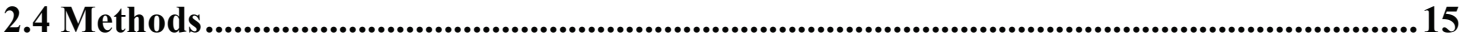

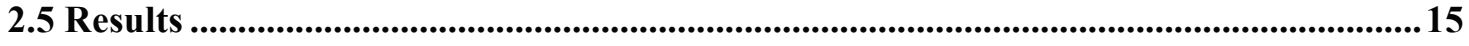

2.5.1 Stratigraphic Members, Wynniatt Formation.......................................................... 15

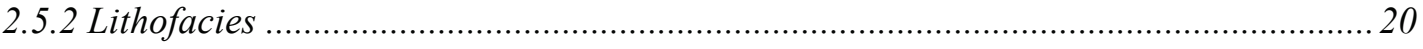

2.6.1 Depositional Framework Interpretation................................................................. 44

2.6.2 Ramp Evolution of the Wynniatt Formation ............................................................. 47

2.6.3 Ramp Architecture and Basin Subsidence ............................................................ 49

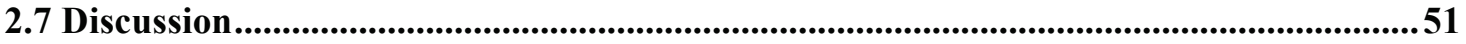


2.7.1 Subsidence patterns during deposition of Wynniatt Formation ..................................51

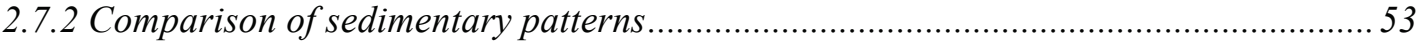

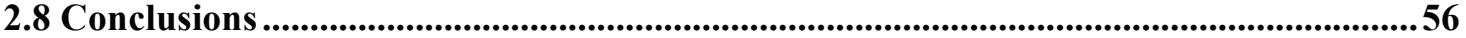

\section{CHAPTER 3: TRANSGRESSIVE-REGRESSIVE CYCLES AND} TECTONOSTRATIGRAPHY OF THE UPPER SHALER SUPERGROUP ......... 57

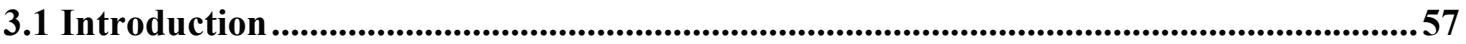

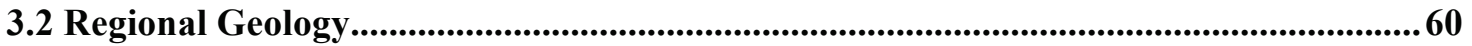

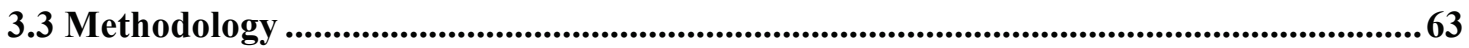

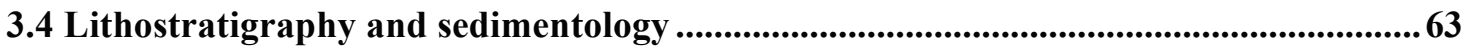

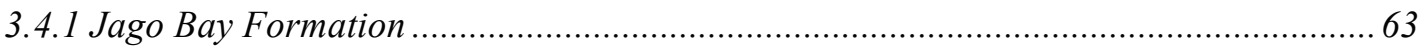

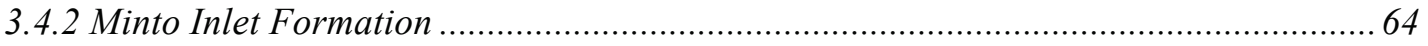

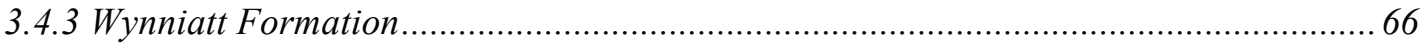

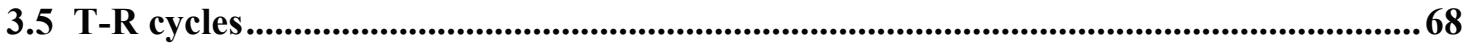

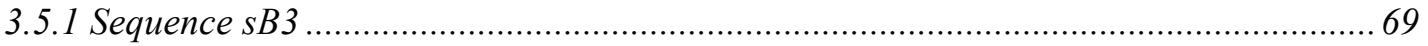

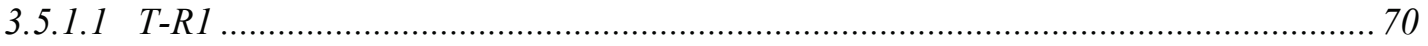

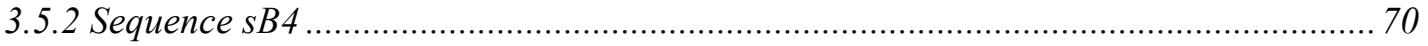

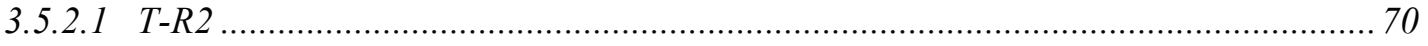

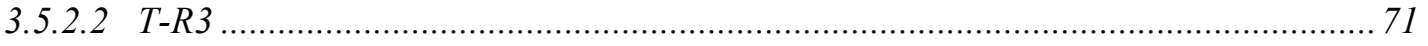

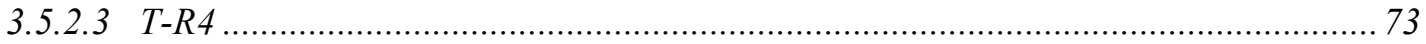

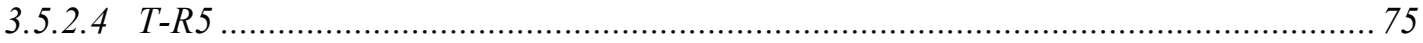

3.6 Correlation with adjacent basins............................................................................................. 76

3.7 Cause of cyclicity ........................................................................................................................... 79

3.8 Basin duration, subsidence patterns and tectonostratigraphy .....................................80

3.9 Inferences for the break-up of Rodinia along the northwest margin of Laurentia .....85

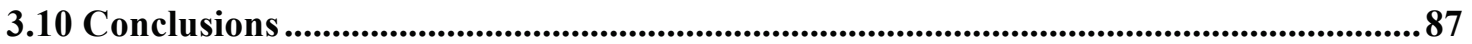

CHAPTER 4: CHEMOSTRATIGRAPHY AND GEOCHEMISTRY ...................... 89

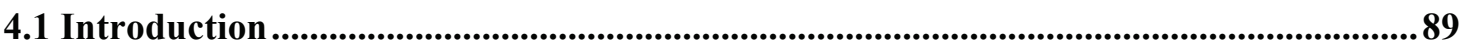

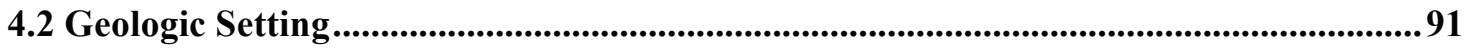

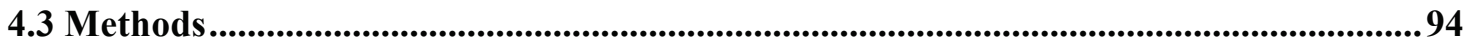

4.3.1 Geochemical approach to paleoredox interpretation................................................ 94

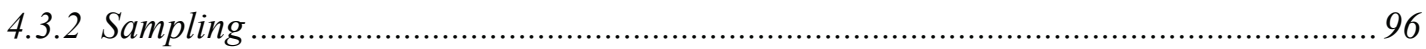

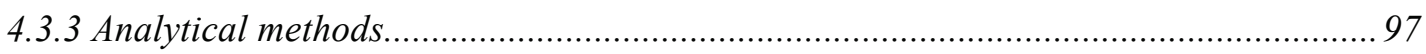


4.4 Results and Basic Data Interpretations ..................................................................100

4.4.1 Carbon isotopes and carbonate sedimentology ................................................... 100

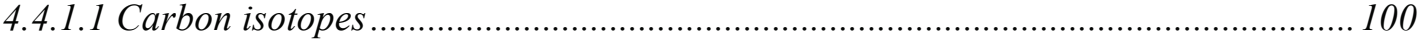

4.4.1.2 Sedimentology and stratigraphy of the negative excursion stratigraphic interval.. 102

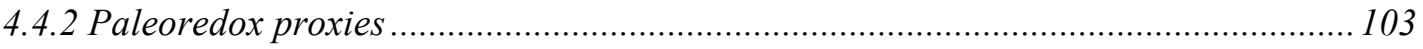

4.5 Discussion ....................................................................................................................................... 107

4.5.1 Testing existing correlations with new chemostratigraphic data ............................ 107

4.5.2 Negative carbon isotope anomalies: Evaluation of the different mechanisms and an interpretation for the Amundsen Basin .......................................................................... 113

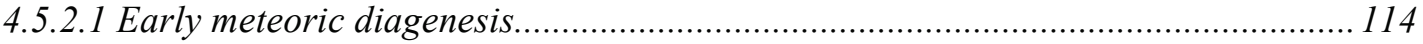

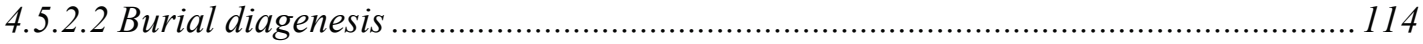

4.5.2.3 a Change in primary seawater chemistry by oxidation of organic matter ............... 115

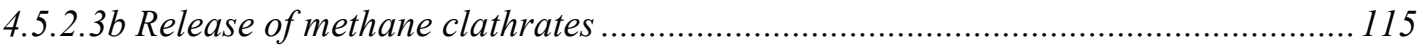

4.5.2.4 Precipitation of authigenic carbonate ……..................................................... 116

4.5.2.5 Synthesis: Interpretation for the Amundsen Basin ........................................... 117

4.5.3 Euxinia and redox-sensitive trace metal enrichments in the Amundsen Basin ......... 120

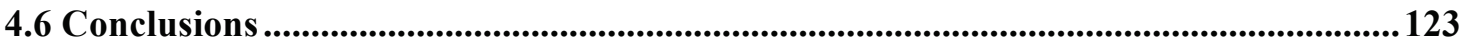

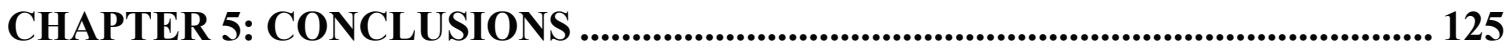

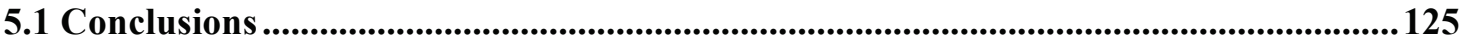

5.2 Future Research .................................................................................................................... 127

REFERENCES........................................................................................................ 129

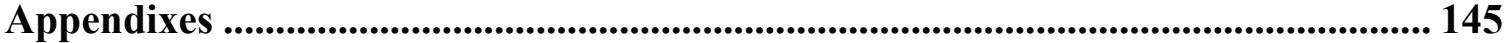




\section{LIST OF FIGURES}

Figure 1. Geology of the Minto Inlier (after Thorsteinsson and Tozer, 1962) and stratigraphy of the Shaler Supergroup, with study locations highlighted by stippled ovals. The NE study area also corresponds to the study area of Jones et al. (2010). Note the black star is the location of drill core GNME 07-04. Inset in top left corner shows Victoria Island in grey, the bounding box is the extent of the map. Re-Os ages from van Acken et al. (2013), U-Pb detrital zircon ages from Rayner and Rainbird (2013), and U-Pb lead ages from Heaman et al. (1992) and Macdonald et al. (2010).

Figure 2. Paleogeographic reconstuction of Rodinia, modified from Evans, 2009.

Location of Amundsen Basin indicated and epeiric sea with interconnecting seaways overlain. There are several different reconstructions of Rodinia that have been proposed, the paleogeographic fit of the continents is still being debated. I chose to present this version as an example because it highlights the interior sea, where the Amundsen Basin is located. Most workers now agree however that Laurentia was situated at the core of Rodinia, likely with Siberia to the north and Australia to the west.

Figure 3. Selected measured section localities, Wynniatt Formation. Dashed red lines show approximate lines of where the sections were measured. 1) Sections 10DTS3 and 10DTS4 from the SW part of the inlier (see Table 1 for locations). View to the north-northeast across Minto Inlet. Mi (Minto Inlet Formation) overlain by LCM (Lower Carbonate Member), BSM (Black Shale Member), and SCM (Stromatolitic Carbonate Member). 2) Section 10DTS8, showing the contact of the SCM and UCM (Upper Carbonate Member). View to the north, SW Minto Inlier. 3) Section 11DTS9 measured in the NE part of the inlier, where the LCM, BSM, and part of the SCM are exposed. View to the southwest.

Figure 4. Sections through the members of the Wynniatt Formation. Coordinates for sections are provided in Table 1. The Black Shale member and Upper Carbonate member sections are composite sections. Note: stratigraphic location of TawuiaChuaria assemblage shown at the Black Shale and Stromatolitic Carbonate member contact, correlated from Hofmann and Rainbird (1995). Sh - shale, m - mudstone, w - wackestone, $\mathrm{p}$ - packstone, $\mathrm{g}$ - grainstone, stm - stromatolitic lime/dolostone, $\mathrm{r}$ rudstone.

Figure 5. Legend for stratigraphic sections and paleoenvironmental reconstruction. ...... 17

Figure 6. Examples of outer- and mid-ramp facies. Hammer is $30 \mathrm{~cm}$ long. A) Carbonaceous calcareous black shale and calcarenite facies (F1), photo from drill core GNME 07-04. B) Lithoclastic float/rudstone with dololutite matrix facies (F2). C) Thin-bedded calcarenite facies (F3). D) Conoform stromatolitic dolostone facies 
(F7). E) Dark grey siltstone and silty shale facies (F5). F) Molar-tooth mudstone facies (F8).

Figure 7. Photographs of $M g$-silicate and evaporite facies (F4). Hammer is $30 \mathrm{~cm}$ long. A) Nodular bedded calcareous shale and Mg-silicate. B) Bottom-grown crusts of gypsum replaced by dolomite in a ferroan calcite matrix. Thin section has been died using Alizarin Red. C) Mg-silicate clast debrite in a calcareous shale matrix. D) Enigmatic diagenetic texture resembling leisegang banding. E) Doubly-fibrous Mgsilicate (Mg-Si) crystals within a calcium carbonate (CC) matrix. F) Slump folds within lime mudstone.

Figure 8. Examples of mid- to inner ramp facies. Hammer is $30 \mathrm{~cm}$ long. A) Crossbedded intraclast grainstone facies (F10). B) Molar-tooth clast packstone facies (F9). C) Lithoclast floatstone with grainstone matrix facies (F11). D) Polished slab of oncoid-digitate stromatolite facies (F12). Note the yellow arrow points to a broken piece of stromatolite that the oncoid is nucleated on, and that digitate stromatolites grew upward (toward top of photo) from the top of the oncoid. E) Cross-bedded peloid grainstone facies (F14). Note the apparent bi-directionality of the cross-beds shown in this photo (arrows). F) Dolomitic siltstone with desiccation cracks facies (F15).

Figure 9. Examples of variation in columnar stromatolite facies (F13). A) Columnar stromatolites with coarse intercolumnar sediment. B) Aerial view of an outcrop of exhumed stromatolite mounds in the Upper Carbonate member. Field of view is approximately $250 \mathrm{~m}$; object in lower right is a helicopter skid. C) Small, domal bioherm of honeycomb-shaped, digitate, unbranching columnar stromatolites. Growth directions range from horizontal at the base to vertical at the top. D) Elongate stromatolitic reef (unbedded area on right side) in the upper carbonate member with flanking, tabular-bedded grainstones. Person circled for scale is approximately $1.5 \mathrm{~m}$ tall. E) Columnar stromatolites in the upper carbonate member, identified as form genus Tungussia? F) Columnar stromatolites in the stromatolitic carbonate member.

Figure 10. Examples of inner ramp facies. A) Domal stromatolite facies (F16). Bedding surface of laterally linked hemispheroid stromatolites. B) Cross-bedded quartzarenite facies (F17). C) Flaser-lenticular bedded, quartzose dolosiltite and dolarenite facies (F18). D) Laminated lime/dolomudstone facies (F19). Scale card in $\mathrm{B}$ and $\mathrm{D}$ is $8 \mathrm{~cm}$ wide.

Figure 11. Block diagram showing the generalised distribution of facies assemblages from inner to outer ramp. There is considerable heterogeneity in the inner ramp, with lagoon, supra- and intertidal mudflats, tidal creeks, and sand shoal depositional environments. Mid-ramp deposits include stromatolite buildups. The ramp is distally steepened, as indicated by the slope break on the outer ramp. The inset shows DE2, when the development of a delta drowned the carbonate factory with an influx of siliciclastic sediments. 
Figure 12. Isopach maps of sediment thickness. Top map shows the paleogeography of northwest Laurentia during deposition of the Wynniatt Formation, modified from Rainbird et al. (1996). The grey area represents land, the blue is water. The estimated zero edge of deposition is shown along the approximate location of the Great Bear Arch; the thickest accumulation of sediment is in the southwest of the Minto Inlier, which thins towards the northeast, forming an interpreted concentric pattern. The bottom three inset maps show migration of the depocentre location during the three different ramp successions of the Wynniatt Formation, where accumulation was thickest in the southwest during deposition of the Lower Carbonate member (LCM) and Black Shale member (BSM) and Upper Carbonate member (UCM), and thickest in the northeast of Minto Inlier during deposition of the Stromatolitic Carbonate member (SCM). All of the dashed lines shown are interpretive, there is no direct field evidence to draw isolines as they are shown, however they are best-guess estimates given the geology and known thicknesses.. 50

Figure 13. Correlation chart of the Shaler Supergroup (after Rainbird et al., 1994 and references therein), Mackenzie Mountains Supergroup (after Turner and Long, 2012 and references therein), and Fifteenmile Group (after Macdonald et al., 2012 and references therein), and map showing the localities of Proterozoic outcrops (shown in black) in northern Canada and Alaska and the estimated paleomargin of Laurentia (modified from Young et al., 1981)......

Figure 14. Correlation of Fifteenmile Group, Mackenzie Mountains Supergroup, and Shaler Supergroup stratigraphy, with sequences indicated. References for stratigraphy and $\mathrm{U}-\mathrm{Pb}$ dates provided on the figure underneath stratigraphic columns. Tripartite Sequence A, B, and C division modified from Young (1981). Sub-sequences sB1-5 after Long et al. (2008). Higher order sequences for Fifteenmile Group after Macdonald et al. (2012); Kilian and Kuujjuua formations after Rainbird (1993). The grey area represents stratigraphy that we consider correlative, with black dashed lines showing approximate correlations of cycles... 62

Figure 15. Measured stratigraphic sections of the Jago Bay and Minto Inlet formations. Interpretations of T-R cycles are shown. Inset map shows locations of stratigraphic sections.

Figure 16. Measured stratigraphic sections of the Wynniatt Formation and members, with T-R cycles, parasequences, and important stratigraphic surfaces indicated. Refer to Figure 16 for a map of stratigraphic section locations.

Figure 17. (previous page) Southwest to northeast cross-section of the Wynniatt Formation, showing regional T-R cycle correlations. LCM - Lower Carbonate member, BSM - Black Shale member, SCM - Stromatolitic Carbonate member, UCM - Upper Carbonate member.

Figure 18. Photographs of sequence boundaries and T-R cycles in outcrop. (A) Shoreline ravinement (SR) and boundary surface between T-R2 and T-R3 in the Lower Carbonate member. (B) Subaerial unconformity (SU) and boundary between T-R3 and T-R4 in Stromatolitic Carbonate member. (C) Maximum surface of regression 
(MRS) and boundary between T-R4 and T-R5 at the contact between the Stromatolitic Carbonate member and Upper Carbonate member. (D) Cycles composed of sharp-based, orange weathering, thin-bedded dolostone grading upward into laminated black shale interpreted as upward-deepening parasequences (green arrows) near the top of Lower Carbonate member. (E) Maximum flooding surface (MFS) above the T-R4 and T-R5 contact. The boundary between the two is marked by a maximum surface of regression (MRS) that coincides with the Stromatolitic Carbonate member and Upper Carbonate member contact. (F) Excavated contact between the Wynniatt Formation and overlying Kilian Formation, which forms the sB4 - sB5 (cf. Long et al., 2008) boundary

Figure 19. Composite lithostratigraphy, T-R stratigraphy, sequence stratigraphy, and tectonostratigraphy of the Jago Bay, Minto Inlet, Wynniatt, Kilian, Kuujjua, and Natkusiak formations. Lithostratigraphy and T-R stratigraphy of the Kilian Formation after Rainbird (1993). Supersequence boundaries after Young et al. (1981) and sub-sequence boundaries after Long et al. (2008). MDA - maximum depositional age.

Figure 20. Photos of rocks that record the negative carbon isotope excursion in the Upper Carbonate member. A) Outcrop photo of black shale and limestone nodules enveloped by shales showing differential compaction. B) Photo from drill core GNME 07-04. Meter 305 is marked on the core, stratigraphic up is to the right. C) Thin section photo of carbonaceous, calcareous black shale, plane polarized light (PPL). D) Measured section with $\delta^{13} \mathrm{C}_{\text {carb }}$ values overlain. Note that the values suddenly drop over the sharp boundary of the limestone to shale. E) Thin section photo of a calcarenite (turbidite). The bright white is the calcite cement that has infilled pore space surrounding the carbonate sand allochems. PPL

Figure 21. Composite section of the upper Shaler Supergroup. A) $\delta^{13} \mathrm{C}_{\text {carb }}, \delta^{13} \mathrm{C}_{\mathrm{org}}$, and $\delta^{18} \mathrm{O}$ values are shown. Open black circles are data from Jones et al. (2010). B) Mo, $\mathrm{V}, \mathrm{U}$ (in ppm), Mo, V, and U (normalized to TOC), TOC, and $\delta^{34} \mathrm{~S}_{\mathrm{py}}$ data. C) Cross-

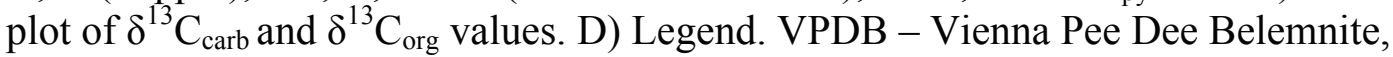
VCDT - Vienna Canyon Diablo Troilite, TOC - total organic carbon. 101

Figure 22. Geochemical data from drill core GNME 07-04 spanning the Bitter Springs stage. Interpretation of paleoredox conditions is shown beside the stratigraphic section. The typical continental margin baseline for Fe speciation parameters is indicated by the vertical red lines. Note: the location of this core is indicated on Fig. 1 by a black star, and the $\mathrm{V}$ data is presented using a log scale. Re-Os age is from van Acken et al. (2013). EOH - end of hole, sh - shale, are - arenite, rud - rudstone, VPDB - Vienna Pee Dee Belemnite, VCDT - Vienna Canyon Diablo Troilite, PPM - parts per million. 105

Figure 23. Potential correlation of the Shaler Supergroup with the Fifteenmile Group and Mackenzie Mountains Supergroup based on lithostratigraphy and $\delta^{13} \mathrm{C}_{\text {carb }}$ data. Data from the Ogilvie Mountains is after Macdonald et al. (2012), data from the Mackenzie Mountains is after Halverson et al. (2006). Inset map shows location of the Amundsen Basin with respect to the Ogilvie and Mackenzie mountains. Two red 
arrows point to the "double positive peak" that occurs below the Bitter Springs stage, which is highlighted in orange. The green bar highlights the correlation of the Boot Inlet Formation with the Stone Knife, Silverberry and Gibben formations. The grey bar highlights the negative $\mathrm{C}$ isotope values of the siliciclastic-dominated Fort Collinson Formation that may reflect early diagenetic alteration. DCF - Dodo Creek Formation, $1 \mathrm{~cm}$ - Lower Carbonate member, bsm - Black Shale member, scm -

Stromatolitic Carbonate member, ucm - Upper Carbonate member.

Figure 24. Schematic diagram representing our interpretation of events that led to the negative carbon isotope excursion in the Wynniatt Formation, and how they relate to global tectonics, sea-level changes, and basin-scale to global seawater composition. Before the Bitter Springs stage waters were oxygenated, there was a large seawater sulphate reservoir, and high relative rates of organic carbon burial resulted in a positive $\delta^{13} \mathrm{C}_{\text {carb }}$ excursion and buildup of methane clathrates in the sediments. During the Bitter Springs stage, a transgression occurred in the Amundsen Basin as Laurentia rotated, positioning the basin at equatorital latitudes and increasing local productivity. At the same time, basin restriction resulted in local anoxic to euxinic conditions. Methane clathrates reacted with the seawater oxidants, and contributed light carbon to DIC pool. This signal was further amplified in pore waters, where methane and organic matter were oxidized driving precipitation of authigenic carbonate cement with highly negative carbon isotope values. After the Bitter Springs stage, settings returned to previous conditions. TWP - true polar wander, py - pyrite, VPDB - Vienna Pee Dee Belemnite. ....................................................... 118 


\section{LIST OF TABLES}

Table 1. Descriptions of members of the Wynniatt Formation. MMSG - Mackenzie Mountains Supergroup, FMG - Fifteenmile Group. …………………………...... 19

Table 2. Depositional environments and facies of the Wynniatt Formation. .................... 41 


\section{APPENDIXES}

Appendix 1. Locations and descriptions of measured outcrop sections and drill core... 146

Appendix 2. Stable isotope data ……………………............................................... 147

Appendix 3. Trace element data. MDL - maximum detection limit.............................. 160

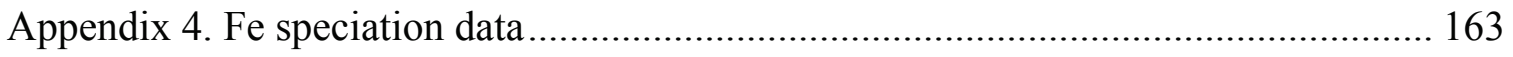

Appendix 5 Legend for measured stratigraphic sections.............................................. 166

Appendix 6 10DTS1, Minto Inlet Formation .............................................................. 167

Appendix 7 10DTS2, Minto Inlet Formation ………………….................................... 168

Appendix 8 10DTS3, Lower Carbonate member ............................................................ 169

Appendix 9 10DTS4a, Black Shale member ............................................................... 170

Appendix 10 10DTS4b, Black Shale member................................................................ 171

Appendix 11 10DTS5, Black Shale and Stromatolitic Carbonate members .................. 172

Appendix 12 10DTS6 and 10DTS12, Upper Carbonate member ................................. 173

Appendix 13 10DTS7, Stromatolitic Carbonate member................................................ 174

Appendix 14 10DTS8, Stromatolitic Carbonate and Upper Carbonate members ......... 175

Appendix 15 10DTS9, Upper Carbonate member..................................................... 176

Appendix 16 10DTS10, Stromatolitic Carbonate member............................................... 177

Appendix 17 10DTS11, Lower Carbonate and Black Shale members.......................... 178

Appendix 18 11DTS2, Upper Carbonate member........................................................ 179

Appendix 19 10DTS3, Upper Carbonate member....................................................... 180

Appendix 20 11DTS4, Upper Carbonate member......................................................... 181

Appendix 21 11DTS5, Upper Carbonate member........................................................ 182

Appendix 22 11DTS6, Fort Collinson Formation .......................................................... 183

Appendix 23 11DTS7, Upper Carbonate member.......................................................... 184

Appendix 24 11DTS8, Jago Bay Formation............................................................... 185

Appendix 25 11DTS9; Lower Carbonate, Black Shale, and Stromatolitic Carbonate

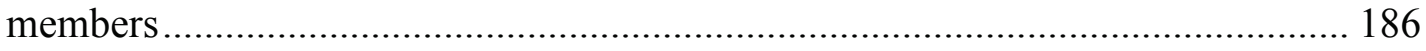


Appendix 26 GNME drill core 06-03, Jago Bay and Minto Inlet formations .............. 187

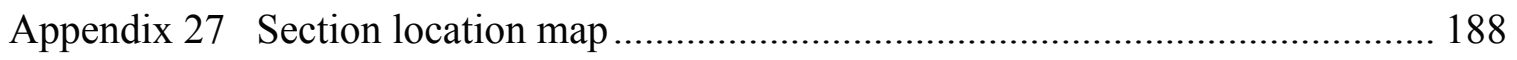




\section{CHAPTER 1: INTRODUCTION}

\subsection{General introduction}

The Neoproterozoic Era is a critical period for understanding Earth history, and currently garners much attention from researchers. The changes that occurred during the Neoproterozoic set the stage for the explosion of metazoan life and the evolution of earth systems to Phanerozoic conditions. During the Neoproterozoic the supercontinent Rodinia was formed and broke apart (e.g., Hoffman, 1991), there were several extensive, low-latitude ice ages (e.g. Kirschivink, 1992), dramatic fluctuations in seawater chemistry that lead to further oxygenation of the atmosphere (e.g. Des Marais et al., 1992), and unique sedimentary textures, such as molar tooth structure, were preserved in rocks (e.g. James et al., 1998).

Situated in the Canadian Arctic, the Tonian-Cryogenian Shaler Supergroup is a thick succession of sedimentary rocks that were deposited in the Amundsen Basin, a shallow intracratonic basin within an epeiric sea that formed at the core of Rodinia. The rocks are well preserved, and are relatively well exposed on Victoria Island, NWT. The Minto Inlier is a northeast trending belt of Neoproterozoic rock exposed on Victoria Island, and is an ideal field locality to study sedimentary rocks of Neoproterozoic affinity (Fig. 1). 
This is a thematic study that was supported by the Geological Survey of Canada's (GSC) Geomapping for Energy and Minerals (GEM) Victoria Island project. Fieldwork was carried out during the summers of 2010 and 2011 on Victoria Island, NWT. The purpose of the GSC's GEM Victoria Island project was to map the southwest portion of

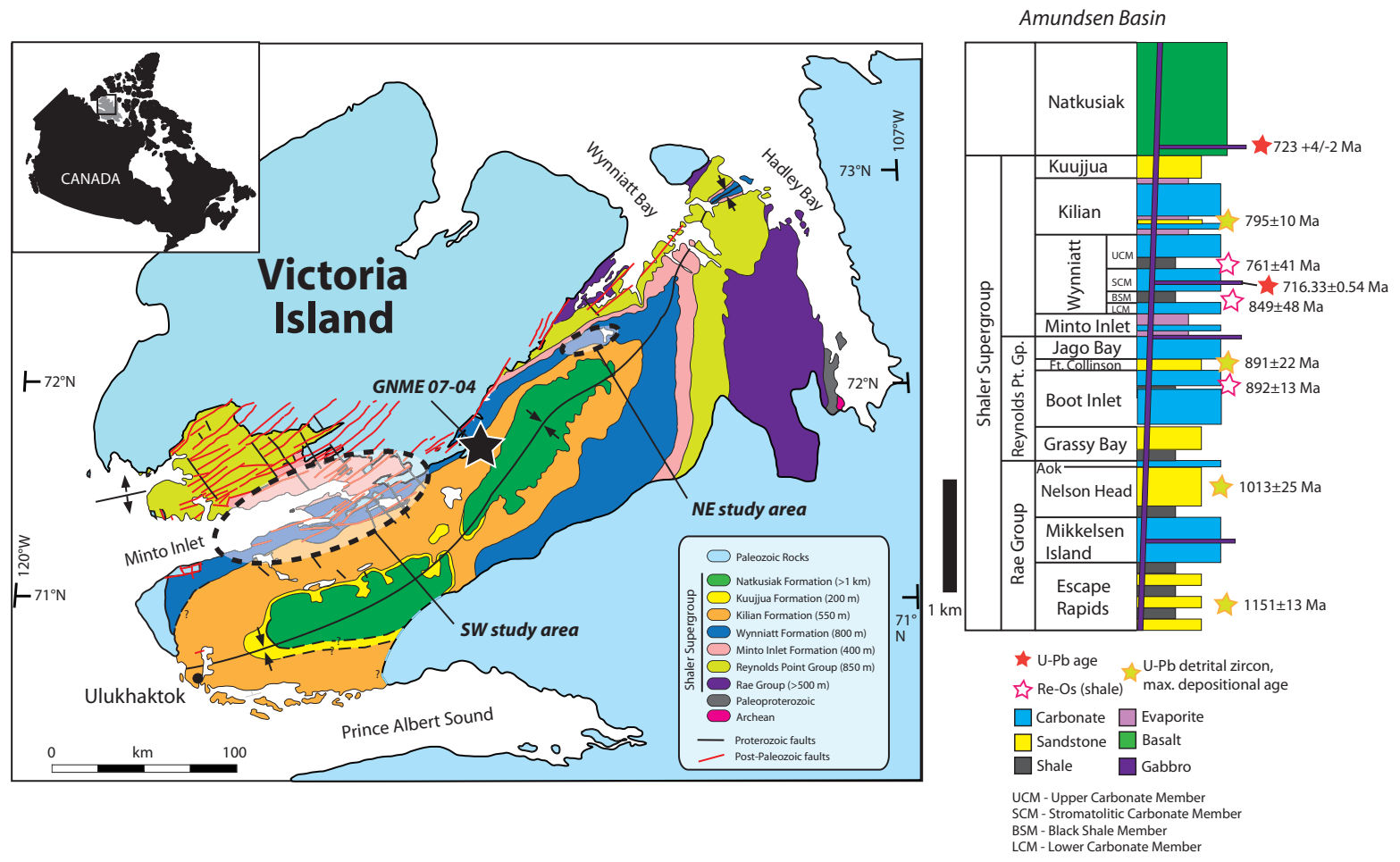

Figure 1. Geology of the Minto Inlier (after Thorsteinsson and Tozer, 1962) and stratigraphy of the Shaler Supergroup, with study locations highlighted by stippled ovals. The NE study area also corresponds to the study area of Jones et al. (2010). Note the black star is the location of drill core GNME 07-04. Inset in top left corner shows Victoria Island in grey, the bounding box is the extent of the map. Re-Os ages from van Acken et al. (2013), U-Pb detrital zircon ages from Rayner and Rainbird (2013), and U-Pb lead ages from Heaman et al. (1992) and Macdonald et al. (2010).

Minto Inlier (Fig. 1), and evaluate the possible economic potential of those rocks. There were several $\mathrm{PhD}, \mathrm{M} . \mathrm{Sc}$, and B.Sc. honours projects associated with the GSC mapping 
project. This project focused on the stratigraphy, sedimentology, and geochemistry of the upper Shaler Supergroup.

Along with detailed outcrop analysis, there is also stratigraphic information preserved in diamond drill cores left in the field by Great Northern Mining Exploration (GNME), who explored for base metals in the Minto Inlier from 2005-2007. Although drilling targeted the Franklin diabase sills, it recovered several hundred meters of sedimentary strata, including almost complete sections of the Jago Bay and Boot Inlet formations, and core through the part of the upper Wynniatt Formation.

\subsection{Location and Access}

The study area is located in the Minto Inlier, on Victoria Island, NWT, Canada. There were two main areas of study, one located in the southwest that centered around Minto Inlet, the other in the northeast, in the vicinity of Kilian Lake (Fig. 1). A list of coordinates for all stratigraphic sections measured is provided in Appendix 1.

The field area is remote and accessed via helicopter or bush plane equipped with tundra tires. One can get a flight to the hamlet of Ulukhaktok from Yellowknife, and from there a helicopter must be taken to access section localities. The sections in the northeast around Kilian Lake are a long flight from Ulukhaktok and require a mid-way fuel cache for a helicopter.

\subsection{Geologic setting}


The Tonian-Cryogenian ( 1000 - 723 Ma) Shaler Supergroup is exposed in several inliers on the mainland and adjacent islands of Arctic Canada (Minto, Cape Lambton, Duke of York, Brock, and Coppermine inliers) (Rainbird et al. 1994; Rainbird et al. 1996; Thorsteinsson and Tozer 1962; Young 1981). On Victoria Island, the Shaler Supergroup is exposed in the Minto Inlier, which preserves a broad NE-SW trending, shallowly dipping, anticline-syncline pair; the Holman Island Syncline-Walker Bay Anticline. The folded Neoproterozoic strata are unconformably overlain by early Cambrian sandstones to late Ordovician carbonates (Thorsteinsson and Tozer, 1962).

The Shaler Supergroup is more than four kilometers thick and composed of fluvio-deltaic sedimentary rocks, platform carbonate rocks and sulphate evaporite rocks interpreted to have been deposited in the Amundsen Basin, a shallow embayment of a larger epeiric sea, situated in the interior of supercontinent Rodinia (Fig. 2; Evans 2009; Li et al. 2008; Rainbird et al. 1996; Rainbird et al. 1998; Young 1981). This epeiric sea would have been periodically connected to the open ocean via seaways, analogous to the Western Interior Sea of North America during the Cretaceous (Williams and Stelck 1975). Rainbird et al., (1996) interpreted the Amundsen Basin as an intracratonic sag basin, based on the lack of synsedimentary faulting, particularly in the lower Shaler Supergroup; as well as the lateral continuity of stratigraphic units, some for over 1000 kilometers (see also Long et al., 2008).

The maximum age of the Shaler Supergroup is constrained by detrital zircon geochronology at $<1151 \mathrm{Ma}$ (Rayner and Rainbird, 2013) and the minimum age at 723 $+4 /-2$ Ma by U-Pb geochronology of diabase sills that feed overlying flood basalts, part 
of the Franklin Large Igneous Province (Heaman et al., 1992). Three depositional ages of

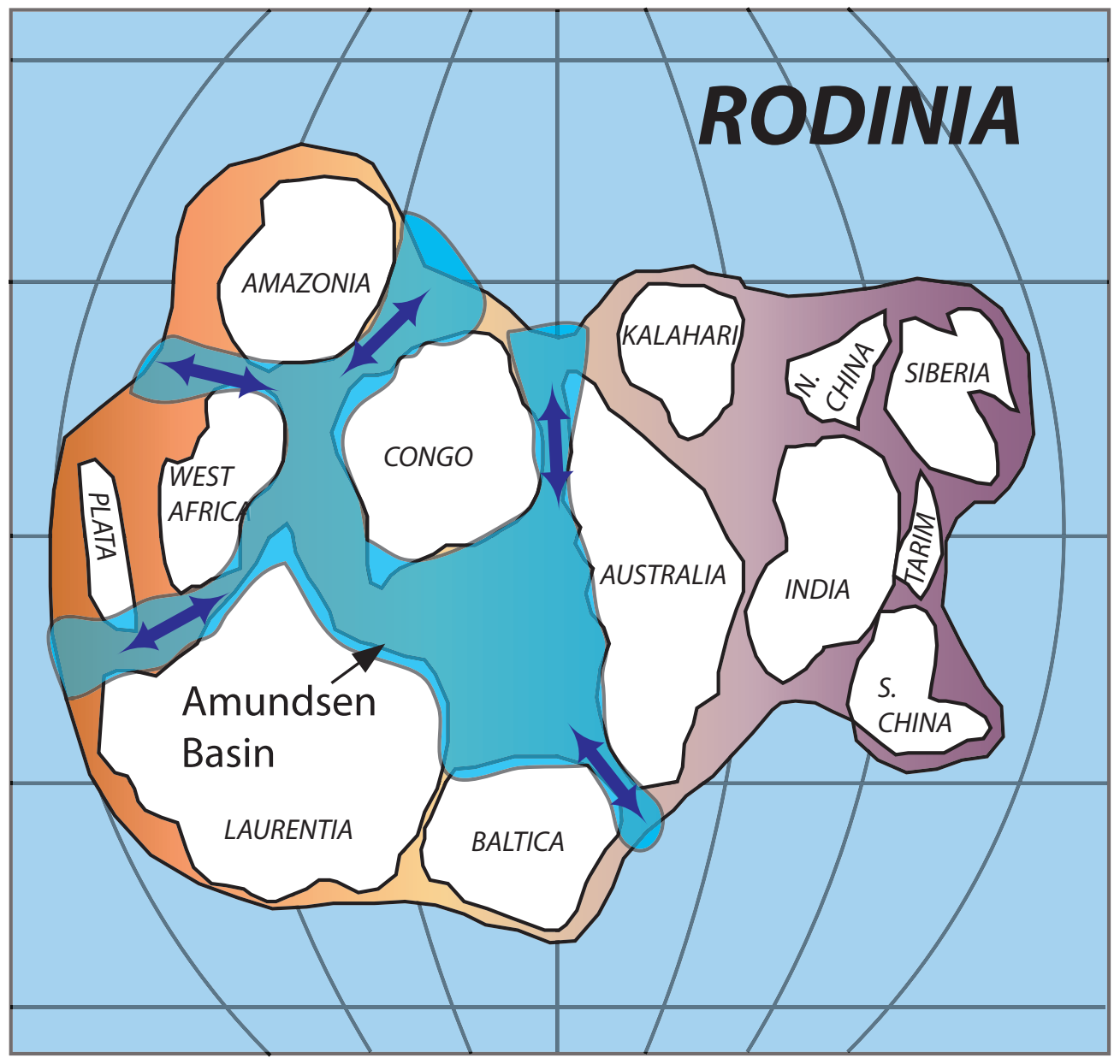

ca. 780 Ma; modified from Evans 2009

Figure 2. Paleogeographic reconstuction of Rodinia, modified from Evans, 2009. Location of Amundsen Basin indicated and epeiric sea with interconnecting seaways overlain. There are several different reconstructions of Rodinia that have been proposed, the paleogeographic fit of the continents is still being debated. I chose to present this version as an example because it highlights the interior sea, where the Amundsen Basin is located. Most workers now agree however that Laurentia was situated at the core of Rodinia, likely with Siberia to the north and Australia to the west.

$892 \pm 13 \mathrm{Ma}$ (Boot Inlet Formation), $849 \pm 48 \mathrm{Ma}$ (Black Shale Member, of the Wynniatt Formation), and $761 \pm 41 \mathrm{Ma}$ (Upper Carbonate Member of the Wynniatt Formation), 
dated using Re-Os black shale geochronology add time resolution to the stratigraphy (Fig. 1; van Acken et al., 2013).

The Shaler Supergroup is composed of, in ascending stratigraphic order, the Rae Group, comprising the Escape Rapids, Mikkelsen Islands, Nelson Head, and Aok formations, the Reynolds Point Group, comprising the Grassy Bay, Boot Inlet, Fort Collinson, and Jago Bay formations, and the ungrouped Minto Inlet, Wynniatt, Kilian, and Kuujjua formations (Fig. 1). The sedimentary rock units are overlain by the Natkusiak Formation, which is composed of continental flood basalts that are fed by the Franklin gabbro sills and dykes, which intrude the sedimentary succession.

The Minto Inlier is an excellent locality for stratigraphic study because: (1) it hosts the most complete and regionally extensive exposure of Shaler Supergroup strata; (2) strata are relatively undeformed with dips typically less than 10 degrees; and (3) rocks have experienced only low-grade contact metamorphism by diabase sills.

\subsection{Previous work}

The first descriptions of the geology of Victoria Island come from the arctic expeditions of O’Neill (1924) and Washburn (1947). Thorsteinsson and Tozer (1962) published a geologic map of Victoria Island, and proposed the Shaler Group and descriptions of the original formations within. Detailed descriptions and stratigraphic logs of sedimentary units are given in Young (1981), which incorporate previous studies on the sedimentology and stratigraphy of the Shaler Supergroup by Young and Long (1976, 1977a, 1977b). Updated descriptions and subdivisions of Minto Inlier stratigraphy is 
provided in Rainbird et al. (1994), where several new formations were introduced, elevating the Rae and Reynolds Point formations to Group status, and the Shaler Group to Supergroup status.

Young (1979) subdivided the Proterozoic stratigraphy of northern Canada into three, unconformity-bound, supersequences. In that framework, the Shaler Supergroup belongs to Sequence B. Long et al. (2008), further subdivided sequence B into five subsequences that correlate across northern Canada. Sequence stratigraphic analysis and sedimentological descriptions of the reefs in the Boot Inlet Formation was preformed by Narbonne and James (2000). Rainbird (1993) interpreted four T-R cycles for the Kilian and Kuujjua formations.

Field observations of the Shaler Supergroup indicate a northwesterly sediment transport direction, and detrital zircon geochronology includes a large proportion of Grenville-age zircons, which led to the interpretation of continental-scale river systems that transported sediments of Grenville affinity across Laurentia, where they were deposited in the Amundsen Basin (Rainbird et al., 1992 \& 1997; see also Rayner and Rainbird, 2013).

Previous geochemical studies on the sedimentary rocks of the Shaler Supergroup include Asmeron et al., (1991), who presented Sr isotope data on all the main carbonate units, and Jones et al., (2010), who presented a C and O isotope chemostratigraphic curve for the Shaler Supergroup, and used this to propose a new stratigraphic correlation scheme with the Mackenzie Mountains Supergroup, located in the Mackenzie Mountains of the northern Cordillera. 
The Tawuia-Chuaria macrofossil assemblage zone was discovered in the Wynniatt Formation by Hofmann and Rainbird (1995), and it was correlated with the upper Little Dal Group, of the Mackenzie Mountains Supergroup. The organic-walled macrofossils are described as carbonaceous compressions, and are unicellular forms of indeterminate affinity. Several different acritarchs, filamentous cyanobacteria, and other microfossils have been described from the Wynniatt Formation (Butterfield and Rainbird, 1998; Butterfield 2005).

\subsection{Study objectives}

The goals of this research project are:

1) To further refine the stratigraphic members of the Wynniatt Formation, Shaler Supergroup. There is presently much global interest in Neoproterozoic successions, and detailed description of this remote succession adds to the greater body of knowledge of carbonate successions from this time period. Further, the Wynniatt Formation was mapped at the member scale (Rainbird et al., 2013), and therefore these members must be properly characterized and defined.

2) Interpret the depositional environments of the Wynniatt Formation. This involves detailed sedimentological descriptions of units, interpretations of different facies, and a working model of the different depositional environments and how they changed through time.

3) To characterize the evolution of the carbonate ramp during deposition of the Wynniatt Formation. If this formation was deposited in $\sim 100$ million years, can one 
recognize discrete stages of ramp development? Are there changes in the depocentre location?

4) To provide a sequence stratigraphic framework for the upper Shaler Supergroup. What is driving subsidence patterns that control cyclicity within the basin? Further, recent studies have documented sudsidence patterns and tectonostratigraphy of strata deposited elsewhere along the margin of Laurentia. How do these patterns compare to those observed in the intracontinental Amundsen Basin?

5) To document $\mathrm{C}$ isotope stratigraphy through the upper Shaler Supergroup, and compare variations observed both locally (NE vs. SW Minto Inlier) and with similar data from the Mackenzie and Ogilvie mountains. Jones et al. (2010) addressed the chemostratigraphy of the Shaler Supergroup in the NE part of the Minto Inlier and recognized a significant negative excursion in the $\delta^{13} \mathrm{C}$ values within the Wynniatt Formation. This anomaly was correlated with the global Bitter Springs Stage, however the samples were collected directly below a $\sim 50 \mathrm{~m}$ thick diabase sill, heat from which could have altered the primary isotope values. Detailed sampling through this interval in the SW portion of the inlier, where no diabase is present in the section, tests the validity of this excursion. New data from both outcrop and drill core is obtained to fill in data gaps.

6) To interpret the cause of the large negative excursion in the Wynniatt Formation and investigate why the negative values are amplified in the Amundsen Basin.

7) To interpret the basin redox history using a multi-proxy approach. Redoxsensitive trace metals, pyrite sulfur isotopes, carbonate carbon and organic carbon 
isotopes, and Fe speciation data is incorporated to interpret the redox history of the Amundsen Basin and how this relates to contemporaneous global seawater patterns.

\subsection{Methodology}

A methods section for each chapter is provided that gives the methodology of specific analytical techniques relating to the analyses done for that specific study. See sections 2.4, 3.3, and 4.3 for specific descriptions of methods used. Stratigraphic analysis was preformed at the outcrop scale for sections measured throughout Minto Inlier. Available outcrop locations imposed restrictions on stratigraphic analysis as they were predominantly limited to a transect that coincided with depositional strike, limiting the construction of cross-sections perpindicular to the regional strike and dip of Amundsen Basin. 


\section{CHAPTER 2: SEDIMENTARY ARCHITECTURE OF THE WYNNIATT FORMATION}

Thomson, D., Rainbird, R.H., Dix, G., 2014. Architecture of a Neoproterozoic intracratonic carbonate ramp succession: Wynniatt Formation, Amundsen Basin, Arctic Canada. Sedimentary Geology, 299: 119-138

\subsection{Introduction}

The geologic record of Neoproterozoic intracratonic basins are now widely distributed on various continents following the breakup of the supercontinent Rodinia (e.g., Li et al., 2008). These types of basins are characterized by: long-lived (>200 m.y.) depocentres with slow subsidence rates that may be coupled with shifting depocentres

(e.g. Howell and van der Pluijm, 1990), lack of major syn-sedimentary faulting, a general paucity of deep-water facies, and basin-fill patterns that are dominated by shallow-marine carbonate strata, basin-central evaporite facies, and terrestrial siliciclastic rocks that may form peripheral coastal facies belts (Allen and Allen, 2005).

These attributes characterize a long-lived (50+ m.y.) carbonate succession constituting the Neoproterozoic Wynniatt Formation, Shaler Supergroup, in the Amundsen Basin of the Canadian Arctic (Fig. 1). The formation is exposed in the Minto Inlier (Fig. 1), in which strata are relatively undeformed and the sedimentary rocks have experienced, at most, only low-grade contact metamorphism associated with intrusion of diabase sills (Fig. 3). We present a sedimentological framework illustrating stages of 
carbonate ramp development allied with changing subsidence depocentres. These
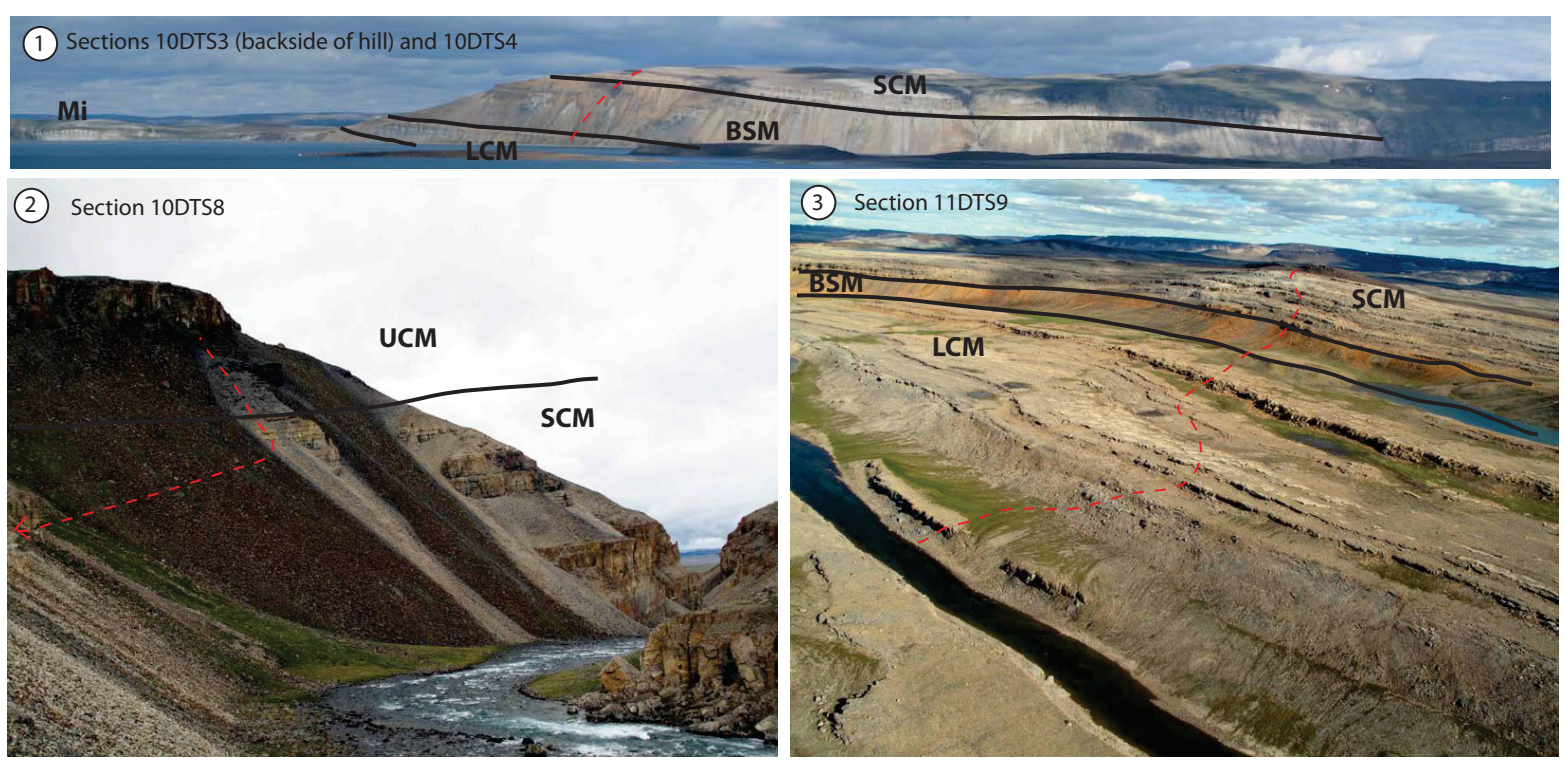

Figure 3. Selected measured section localities, Wynniatt Formation. Dashed red lines show approximate lines of where the sections were measured. 1) Sections 10DTS3 and 10DTS4 from the SW part of the inlier (see Table 1 for locations). View to the north-northeast across Minto Inlet. Mi (Minto Inlet Formation) overlain by LCM (Lower Carbonate Member), BSM (Black Shale Member), and SCM (Stromatolitic Carbonate Member). 2) Section 10DTS8, showing the contact of the SCM and UCM (Upper Carbonate Member). View to the north, SW Minto Inlier. 3) Section 11DTS9 measured in the NE part of the inlier, where the LCM, BSM, and part of the SCM are exposed. View to the southwest.

improve the understanding of basin and carbonate ramp development for a period likely overlapping with initiation ( $\sim 830 \mathrm{Ma}$ ) of supercontinent (Rodinia) breakup and suggest a mechanism to explain local sedimentation patterns, which has implications for interpretations of regional paleogeography and tectonic evolution of Amundsen Basin. Our work provides sedimentary context for sequence and chemical stratigraphy (Jones et al., 2010) and biostratigraphy (Hofmann and Rainbird, 1995) within the Amundsen Basin, and for improved correlation among coeval Neoproterozoic basins. 


\subsection{Geologic Setting}

The Amundsen Basin is interpreted as an intracratonic sag (Rainbird et al., 1996) based on the lack of synsedimentary faulting, particularly in the lower Shaler Supergroup, as well as the lateral continuity of stratigraphic units, some for over 1000 kilometres (see also Long et al., 2008). The basin split apart during break-up of Rodinia but the location of the conjugate margin is unknown (Young, 1981). The Amundsen Basin is interpreted to represent an embayment along a larger epeiric basin within the supercontinent Rodinia (Young, 1981; Rainbird et al., 1996; Rainbird et al., 1998; Li et al., 2008; Evans, 2009). The epeiric sea was episodically connected to the open ocean via seaways, analogous to the Western Interior Seaway of North America during the Cretaceous (Williams and Stelck, 1975).

The Shaler Supergroup is exposed in several inliers on the mainland and adjacent islands of Arctic Canada (Thorsteinsson and Tozer, 1962; Young, 1981; Rainbird et al., 1994; Rainbird et al., 1996) and is represented by more than four kilometres of sedimentary rocks along with intrusive (diabase sills) and extrusive (continental flood basalts) igneous rocks (Fig. 1). The Wynniatt Formation occurs in the upper Shaler Supergroup (Fig. 1), exposed only in the Minto Inlier of Victoria Island (Fig. 1). It conformably overlies basin-central sulphate evaporite and marine carbonate rocks of the Minto Inlet Formation and is unconformably overlain by sabkha-style evaporite rocks and marine carbonate strata of the Kilian Formation (Fig. 1).

A broadly defined geochronological framework for the Shaler Supergroup includes maximum depositional ages based on $\mathrm{U}-\mathrm{Pb}$ detrital zircon geochronology (Fig. 
1), the Escape Rapids Formation gives a lower age of $1115 \pm 13$ Ma (Rainbird et al., 1992;

Rainbird et al., 1997; Rayner and Rainbird, 2013). Shaler Supergroup strata were intruded by diabase sills dated at $723+4 /-2 \mathrm{Ma}$ (Heaman et al., 1992) and $716.33 \pm 0.54$ Ma (Fig. 3; Macdonald et al., 2010). Re-Os geochronology of black shale units representing the lower to middle parts of the Wynniatt Formation identify a depositional age range from $849 \pm 48$ Ma to $761 \pm 41$ Ma, respectively (Fig. 3; van Acken et al., 2013). A negative carbon isotope excursion reported from the Wynniatt Formation is correlated to the global Bitter Springs stage carbon isotope anomaly (Halverson et al., 2005; Jones et al., 2010; Thomson et al., 2012), which has been dated at 811.5 Ma (Macdonald et al., 2010).

\subsection{Previous Work}

The Wynniatt Formation was proposed and first described during reconnaissance geological mapping of Victoria Island by Thorsteinsson and Tozer (1962). There is no type section; a composite section from the northeastern Minto Inlier (Young, 1981) located near the east side of Kilian Lake (Fig. 1) represents the only detailed lithological analysis of the Wynniatt Formation. The Wynniatt Formation contains a diverse assemblage of acritarchs and other organic-walled and filamentous microfossils, and the macrofossils Chuaria and Tawuia (Hofmann and Rainbird, 1995; Butterfield and Rainbird, 1998; Butterfield, 2005). 


\subsection{Methods}

The Wynniatt Formation is divided here into four, informal, regional members, correlated across the Minto Inlier. A total of $20.8 \mathrm{~km}$ of stratigraphic section, including 16 outcrop sections and three drill cores, was measured (Fig. 4; Appendix 1). Owing to the constraints of exposure, some member descriptions rely on composite sections (Fig. 4).

Lithofacies are defined by lithology, texture, and sedimentary structures (Fig. 5). Stromatolites are informally subdivided according to general morphology; in some cases tentative identifications of form-genera are included.

\subsection{Results}

\subsubsection{Stratigraphic Members, Wynniatt Formation}

The basal contact of the Wynniatt Formation with the underlying Minto Inlet Formation is inferred to be gradational based on facies stacking patterns (see below). The Lower Carbonate member (Figs. 4 - 6; Table 1) is characterized by lime mudstone with parallel laminae, desiccation cracks, teepee structures, chert nodules and intraclast breccias in the lower part, wavy to nodular bedded, hummocky cross-stratified grainstone interbedded with molartooth lime mudstone and minor shale in the middle part, and interbedded stromatolitic dolostone, dolograinstone, and black silty shale in the upper part. A regionally extensive marker bed of distinctive orange-weathering stromatolitic dolostone forms the upper 10 metres of the member. The Lower Carbonate and Black 
Shale member contact is gradational. The Black Shale member is a recessive interval of
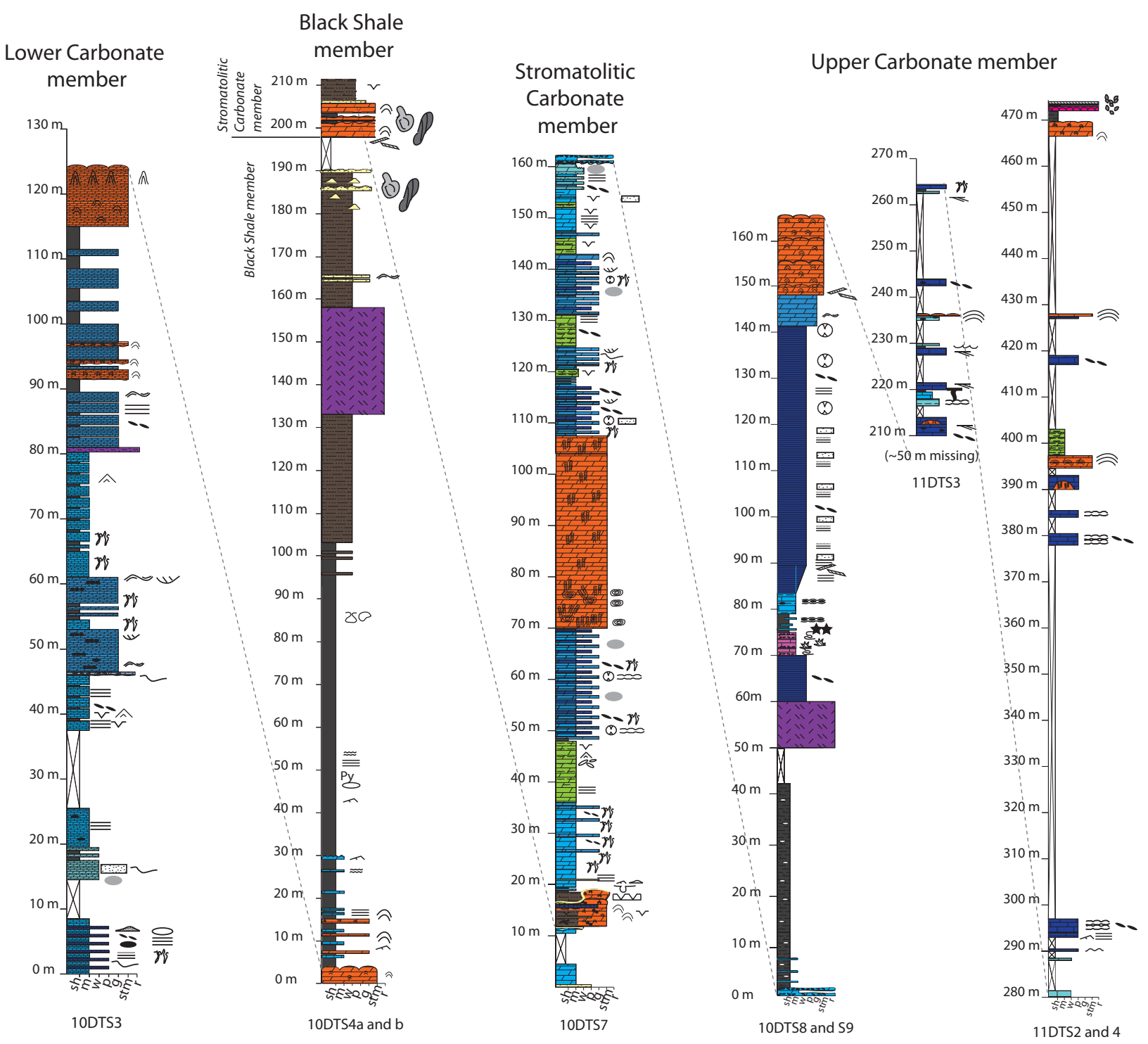

Figure 4. Sections through the members of the Wynniatt Formation. Coordinates for sections are provided in Table 1. The Black Shale member and Upper Carbonate member sections are composite sections. Note: stratigraphic location of Tawuia-Chuaria assemblage shown at the Black Shale and Stromatolitic Carbonate member contact, correlated from Hofmann and Rainbird (1995). Sh - shale, m - mudstone, w wackestone, $\mathrm{p}$ - packstone, $\mathrm{g}$ - grainstone, stm - stromatolitic lime/dolostone, $\mathrm{r}$ - rudstone. 
dark-grey siltstone and silty shale with flute and gutter casts, ball and pillow structures, channel and fill structures, and climbing ripple marks in siltstone. Thin- to medium-thick, discontinuous-to-continuous beds of ripple-topped quartz arenite are dispersed

\section{Legend}

Composition
stromatolitic
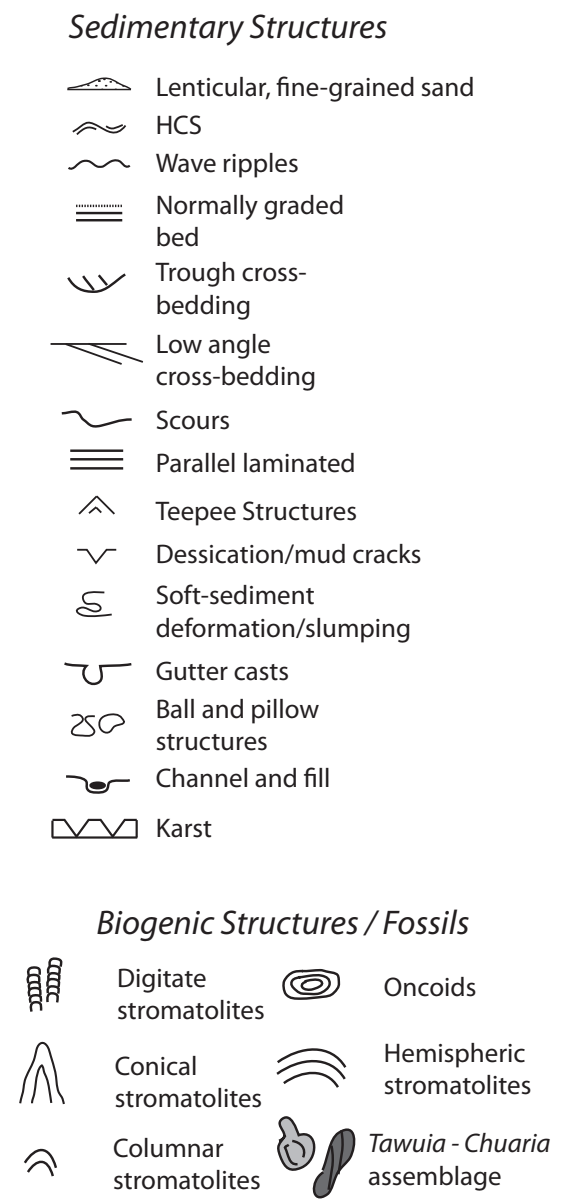

Figure 5. Legend for stratigraphic sections and paleoenvironmental reconstruction. 
throughout the member but are more commonly preserved near its top. The TawuiaChuaria zone described by Hofmann and Rainbird (1995) was documented from the upper $\sim 5 \mathrm{~m}$ of this member, as well as a diverse suite of acritarchs and other organicwalled and filamentous microfossils (Butterfield and Rainbird, 1998; Butterfield, 2005), from within an interval of wavy-lenticular sandstones interbedded with siltstone and shale. The Black Shale and Stromatolitic Carbonate member contact is gradational. The Stromatolitic Carbonate member contains four main lithologies: stromatolitic dolostone, intraclast grainstone, molartooth mudstone, and mud-cracked dololutite. A regionally extensive interval of stromatolitic dolostone contains oncolites up to $20 \mathrm{~cm}$ in diametre (see Fig. 8). The Stromatolitic Carbonate and Upper Carbonate member contact is sharp. The lower Upper Carbonate member is composed of nodular, black, calcareous shale, succeeded by a thick middle interval of thinly bedded, quartz-sandy, normally graded calcarenite, overlain by a rhythmic successions of metre- to decimeter-thick interbedded stromatolitic dolostone and crossbedded intraclast grainstone. The contact with the overlying Kilian Formation is unconformable. 


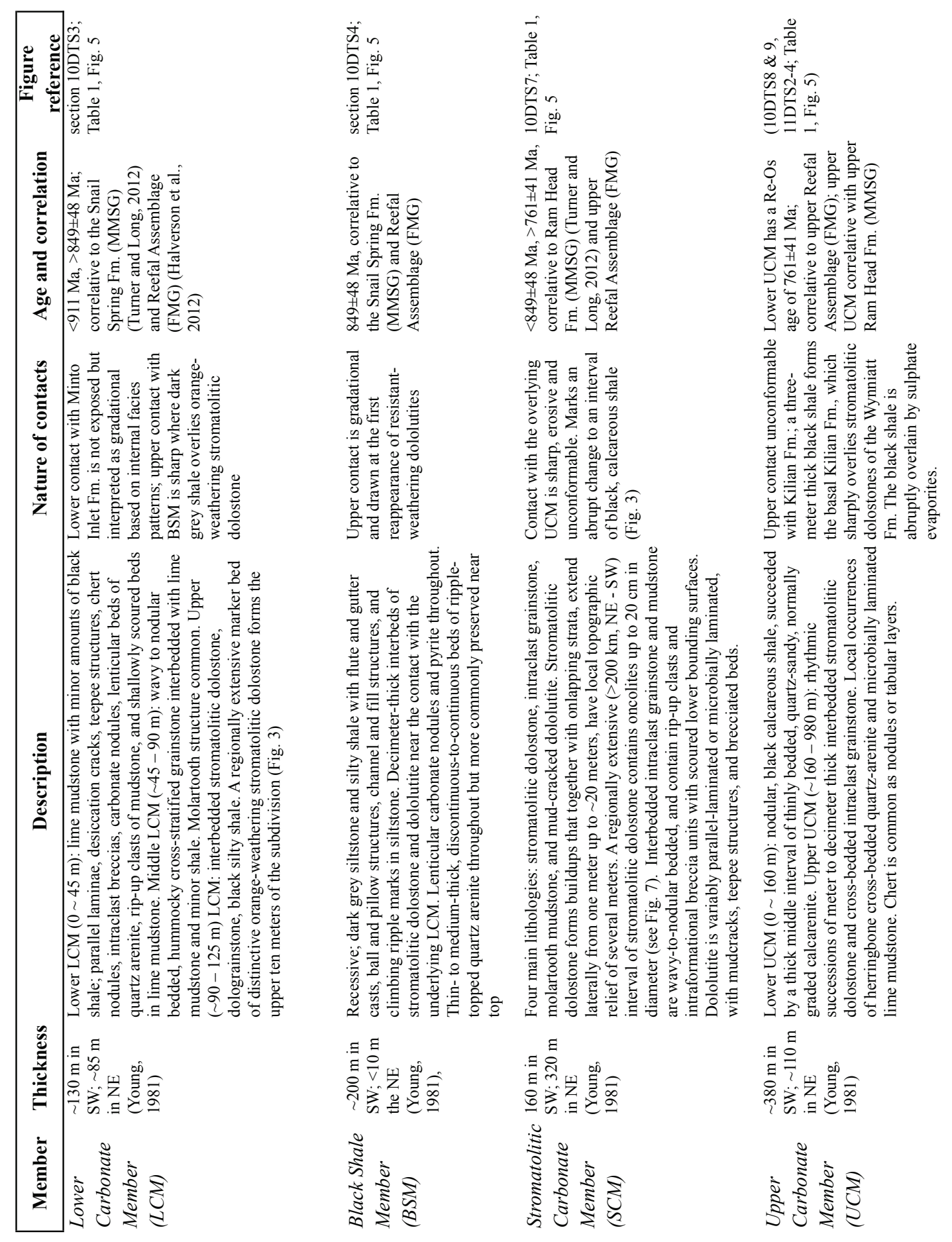

Table 1. Descriptions of members of the Wynniatt Formation. MMSG - Mackenzie Mountains Supergroup, FMG - Fifteenmile Group. 


\subsubsection{Lithofacies}

\subsubsection{Carbonaceous calcareous black shale and calcarenite facies (F1; Table 2)}

Description.--- This facies consists predominantly of laminated carbonaceous calcareous black shale. It is interstratified with laminae of green calcisiltite, thin beds of grey calcareous claystone, and massive to nodular beds ( $>20 \mathrm{~cm}$ thick) of calcarenite composed of rounded lithoclasts of fine to medium sand with erosive or sharp bases, and flattened discoidal lenses ( $<50 \mathrm{~cm}$ in diameter) of similar calcarenite (Fig. 4). Loading and dewatering structures (flame structures) are present in the shale. Disseminated crystalline pyrite occurs throughout. Early seafloor dissolution and cementation is visible along bedding contacts as irregular contacts that are buckled or micro-fractured, and are draped by overlying shale. Beds typically are cemented early by micritic calcite cement. Paleoporosity is filled by blocky, subhedral, cloudy, non-equidimensional calcite cement.

Interpretation.--- This facies is interpreted to represent predominantly suspension sedimentation below storm wave base (SWB) on the outer slope. Calcarenite beds are interpreted as turbidites, and correspond to Bouma Ta subdivisions. Nodules of calcarenite, the same composition as Ta turbidites, were formed in situ during early diagenesis, as uneven sediment loading and compaction resulted in differential compaction of shale around the nodules. Early-cemented beds reflect condensed intervals or periods of non-deposition where sedimentation rates were low enough to allow the seafloor to become at least partially lithified. Pyrite is diagenetic. 

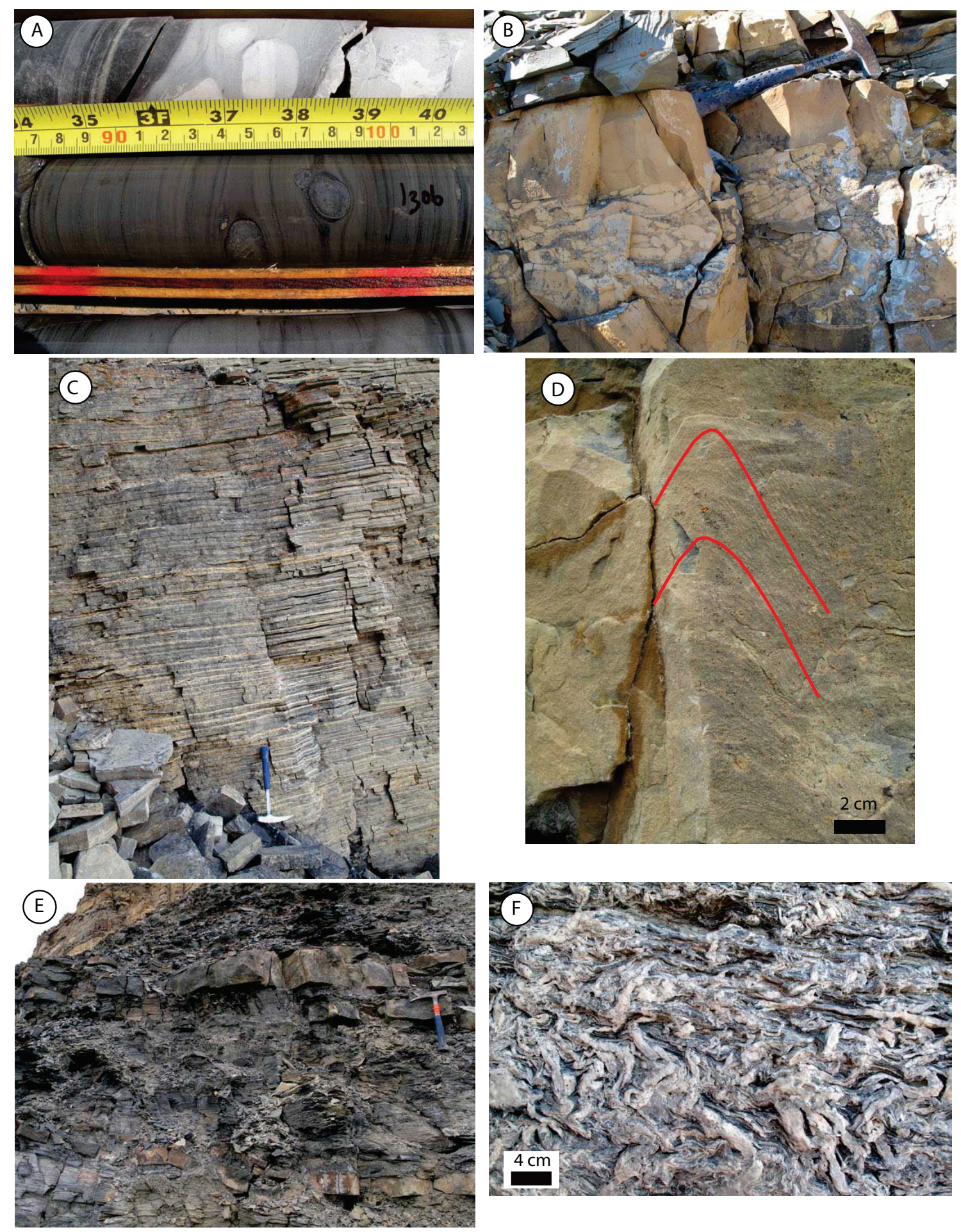

Figure 6. Examples of outer- and mid-ramp facies. Hammer is $30 \mathrm{~cm}$ long. A) Carbonaceous calcareous black shale and calcarenite facies (F1), photo from drill core GNME 07-04. B) Lithoclastic float/rudstone with dololutite matrix facies (F2). C) Thin-bedded calcarenite facies (F3). D) Conoform stromatolitic dolostone facies (F7). E) Dark grey siltstone and silty shale facies (F5). F) Molar-tooth mudstone facies (F8). 


\subsubsection{Lithoclastic float/rudstone with dololutite matrix facies (F2)}

Description.--- This facies is characterized by beds, up to $75 \mathrm{~cm}$ thick, of carbonate rudstone and/or floatstone containing clasts of dololutite that are up to cobblesize, sub-rounded, and tabular (Fig. 6). Lithoclasts may be aligned randomly or imbricated along the bases of beds, which are typically erosional. Clasts are supported in a dololutite matrix. Float/rudstone beds are interbedded with dololutite beds, $5-30 \mathrm{~cm}$ thick. Thin shale interbeds are also associated with this facies.

Interpretation.--- This facies is interpreted as debris flows deposited along the outer slope. Debrites can be transported for long distances along low-angle slopes (Cook and Mullins 1983), but these flows were probably at least initiated at some break-inslope, where the angle of repose steepened to generate debris flows. The similar composition of clasts to underlying beds suggests that float/rudstone beds were cannibalized from underlying strata. This facies is interpreted as slope-derived debrites interbedded with dololutites deposited from suspension, below SWB.

\subsubsection{Thin-bedded calcarenite facies (F3)}

Description.--- This facies comprises thin, regularly layered and well-defined (2 $\mathrm{cm}-10 \mathrm{~cm}$ ) beds of fine-grained calcarenite that are normally graded to parallel laminated (Fig. 6). Thicker beds contain up to $\sim 25 \%$ well-rounded quartz sand grains. Beds have consistent thickness and thin, intervening mud laminae are recessive such that 
the sand beds stick out as ribbons; similar rocks have been referred to as ribbon limestones (i.e. Sherman, et al. 2000). Generally, beds of calcarenite have sharp nonerosive to erosive lower contacts that may preserve thin, coarse-grained lags of randomly oriented tabular clasts of dololutite.

Interpretation.--- Beds of calcarenite correspond to Bouma $\mathrm{Ta}$ and $\mathrm{Tb}$ subdivisions and are interpreted to reflect turbidite deposition. Carbonate sand was derived from higher energy environments that also contained well-rounded quartz sand (e.g. sand shoals), possibly introduced from a nearby coastal setting (e.g. Balazs and Klein 1972), and then redeposited down-slope via turbidity currents possibly triggered by storms. The presence of the Bouma $\mathrm{Tb}$ subdivision supports a more distal position for initiation of turbidity flows.

\subsubsection{Mg-silicate and evaporite facies (F4)}

Description.--- This facies is restricted to the Upper Carbonate member. It occurs only at one locality, stratigraphically positioned within sedimentary rocks of F2, a few metres above sedimentary rocks of $\mathrm{F} 1$. The lower contact of this facies is erosional, and the upper contact is gradational. It consists of approximately 15 metres of interbedded black, poorly indurated calcareous claystone, shale, nodular lime mudstone, and calcisiltite. Sedimentary structures include slump folds, rip-up clasts, chaotic bedding, flat-chip and edgewise breccias, and wavy-nodular compactional bedding (Fig. 7). Enigmatic textures that resemble liesegang bands or some diagenetic front occur in lime 
mudstone (Fig. 7). Petrography reveals bottom-grown crusts $(<1 \mathrm{~mm}$ thick) composed of
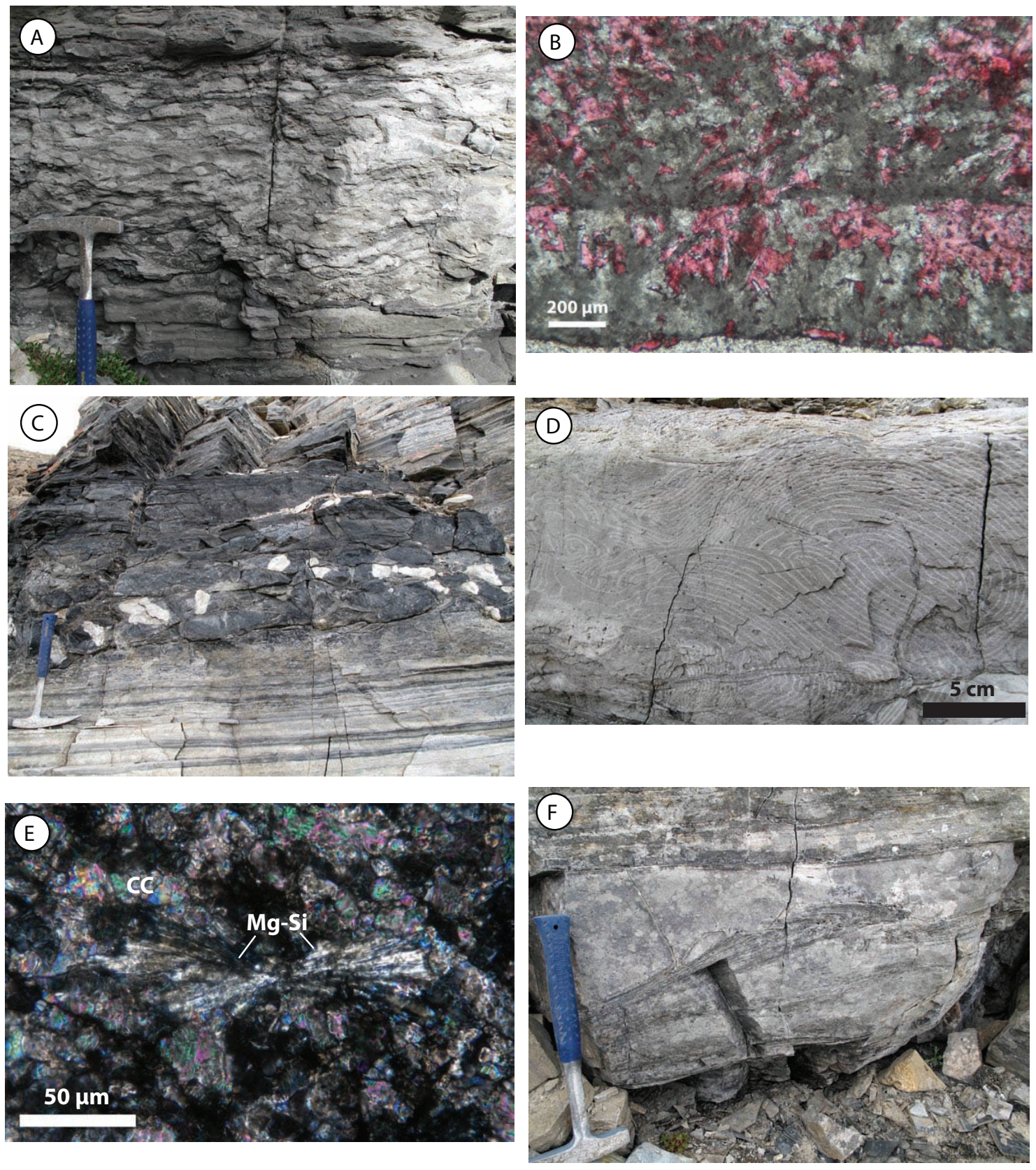

Figure 7. Photographs of Mg-silicate and evaporite facies (F4). Hammer is $30 \mathrm{~cm}$ long. A) Nodular bedded calcareous shale and Mg-silicate. B) Bottom-grown crusts of gypsum replaced by dolomite in a ferroan calcite matrix. Thin section has been died using Alizarin Red. C) Mg-silicate clast debrite in a calcareous shale matrix. D) Enigmatic diagenetic texture resembling leisegang banding. E) Doubly-fibrous Mg-silicate ( $\mathrm{Mg}-\mathrm{Si}$ ) crystals within a calcium carbonate (CC) matrix. F) Slump folds within lime mudstone. 
gypsum bushes that are replaced by dolomite and interlaminated within a ferroan calcite matrix (Fig. 7). Blue-purple, fibrous, doubly radial crystals within a lime mudstone matrix have medium birefringence, yellow-orange interference colours and through SEM analysis are interpreted as a $\mathrm{Mg}$-silicate mineral, most likely talc $\left(\mathrm{Mg}_{3} \mathrm{Si}_{4} \mathrm{O}_{10}(\mathrm{OH})_{2}\right)$.

Interpretation.--- This facies is interpreted to have been deposited below SWB due to its association with other deep-water facies, lack of wave-generated sedimentary structures, and fine-grained nature. Sedimentation was gravity-driven, with preserved debris flows, slumping, and suspension-settled shale. Slump folds allude to the possibility of at least some over-steepening of the slope to allow downward creep of sediments. However, this facies also represents a period of basin restriction allowing precipitation of both sulphate evaporites and sedimentary talc (cf. Tosca et al., 2011). The growth of the talc occurred very early because it does not replace the carbonate, but appears to be intergrown. Bottom-grown crusts of an evaporite mineral suggest that seawater was supersaturated with respect to sulphate, and that the depositional environment was low energy allowing for the growth of this delicate fabric. This quiet-water environment, however, was interrupted by debris flows. Sedimentary talc has also been described from the Callison Lake Dolostone in the Ogilvie Mountains, and Akademikerbreen Group of Svalbard (Tosca et al., 2011), where it is interpreted to have precipitated in shallow water.

\subsubsection{Dark grey siltstone and silty shale facies (F5)}


Description.--- The overall grain size varies from silt- to mud-dominated, with minor amounts of fine-grained sand (Fig. 6). Sedimentary structures include flute and gutter casts, ball-and-pillow, channel-and-fill, tool marks, and ripple crosslamination in siltstone. Siltstone and shale layers are laminated to thinly bedded. Rare beds of thin to thickly bedded, fine- to medium-grained, well-rounded, well-sorted quartz arenite are preserved within the siltstone and shale. Quartz arenite beds are sharp-based and laterally discontinuous preserving hummocky cross-stratification (HCS) and asymmetrical ripple marks. Carbonate nodules and pyrite are present throughout. In thin section, imbricated rip-up clasts of siltstone are present as well as carbonate microconcretions whose cores are commonly partially to completely replaced by pyrite.

Interpretation.--- This facies is interpreted to represent influx of siliciclastic detritus to the basin possible on a pro-delta slope between fair-weather and storm-weather wave base. Sandstone beds represent storm events that reworking delta-front sands and re-deposited them on the slope. HCS is widely accepted as deposited by storm-generated flows (e.g., Walker and Plint 1992; Dumas, et al. 2005). Asymmetric ripples are the result of waning flow during deposition of storm-suspended sands.

\subsubsection{Black shale facies (F6)}

Description.--- Thin beds of black to grey shale are distributed throughout the Wynniatt Formation, either at the tops of upward-deepening successions or at the bases of upward-shallowing successions. Units range in thickness from paper-thin partings between beds, to beds of medium thickness, but most commonly they occur as thin 
interbeds within carbonate rocks. This facies differs from F1 in its lack of carbonate, and from F5 in its lack of sedimentary structures or sandstone interbeds. Also, this facies does not occur in thick successions like those described above.

Interpretation.--- This facies is interpreted as suspension-settled sediment deposited below fair-weather wave base (FWWB), during slack water intervals between storms.

\subsubsection{Conoform stromatolitic dolostone facies (F7)}

Description.--- This facies is composed of conical, columnar stromatolites encased in dolomudstone (Fig. 6) in the Lower Carbonate member. Solitary conical stromatolites attain a maximum observed height of $\sim 20 \mathrm{~cm}$ and width of $\sim 10 \mathrm{~cm}$, with several centimetres of synoptic relief. Wall-parallel laminae are steeply dipping $\left(>70^{\circ}\right)$ with narrow, acute apexes. Inter- and intrastromatolite sediment consists predominantly of dolomudstone.

Interpretation.--- Stromatolites fit the form of Conophyton sp. that are indicative of relatively deep water (e.g. Hoffman 1976), and are typically associated with transgressions (Kah, et al. 2009). Similar facies have been described from the Mesoproterozoic Atar Group in Mauritania (e.g. Bertrand-Sarfati and MoussinePouchkine 1985). There, the lack of coarse-grained interstromatolite sediment and high synoptic relief were interpreted to indicate deposition in quiet water, below FWWB. 


\subsubsection{Molar-tooth mudstone facies (F8)}

Description.--- Light- to dark-grey limestone and dolostone characterize this facies. Beds are thin- to thick-bedded and generally massive. Strata are commonly organic rich and silty, with molar-tooth structure that is sparsely distributed to completely pervasive (Fig. 6). Ptygmatically folded, sub-vertical cracks are the most common form, but horizontal sheet cracks, simple vertical spindle, and tadpole forms are also preserved. Molar-tooth mudstone facies occurs as a monotonous stacking of beds, interbedded with F10 (see below), or at the tops of graded floatstone or packstone beds. Shale is commonly interbedded with beds of molartooth mudstone.

Interpretation.--- Molar-tooth structure is ubiquitous in Proterozoic carbonate rocks and is widely regarded as paleoenvironmentally equivalent to bioturbated, fossiliferous subtidal limestones of the Phanerozoic (James, et al. 1998). There is controversy over the origin of molar-tooth structure, whether it is created through microbially induced gas bubble and expansion cracks (Furniss, et al. 1998), synsedimentary earthquake activity (Pratt 1998), or clathrate destabilization (Marshall and Anglin 2004). Despite the debate on its origin, it is generally agreed that molar-tooth forms within the subtidal depositional regime.

\subsubsection{Molar-tooth clast packstone facies (F9)}

Description.--- Molar-tooth clast packstone facies is most commonly is preserved sharply overlying beds of molar-tooth mudstone (Fig. 8), and is also interbedded with 
F10 (see below). The lower contact between beds is erosive, and the upper contacts may
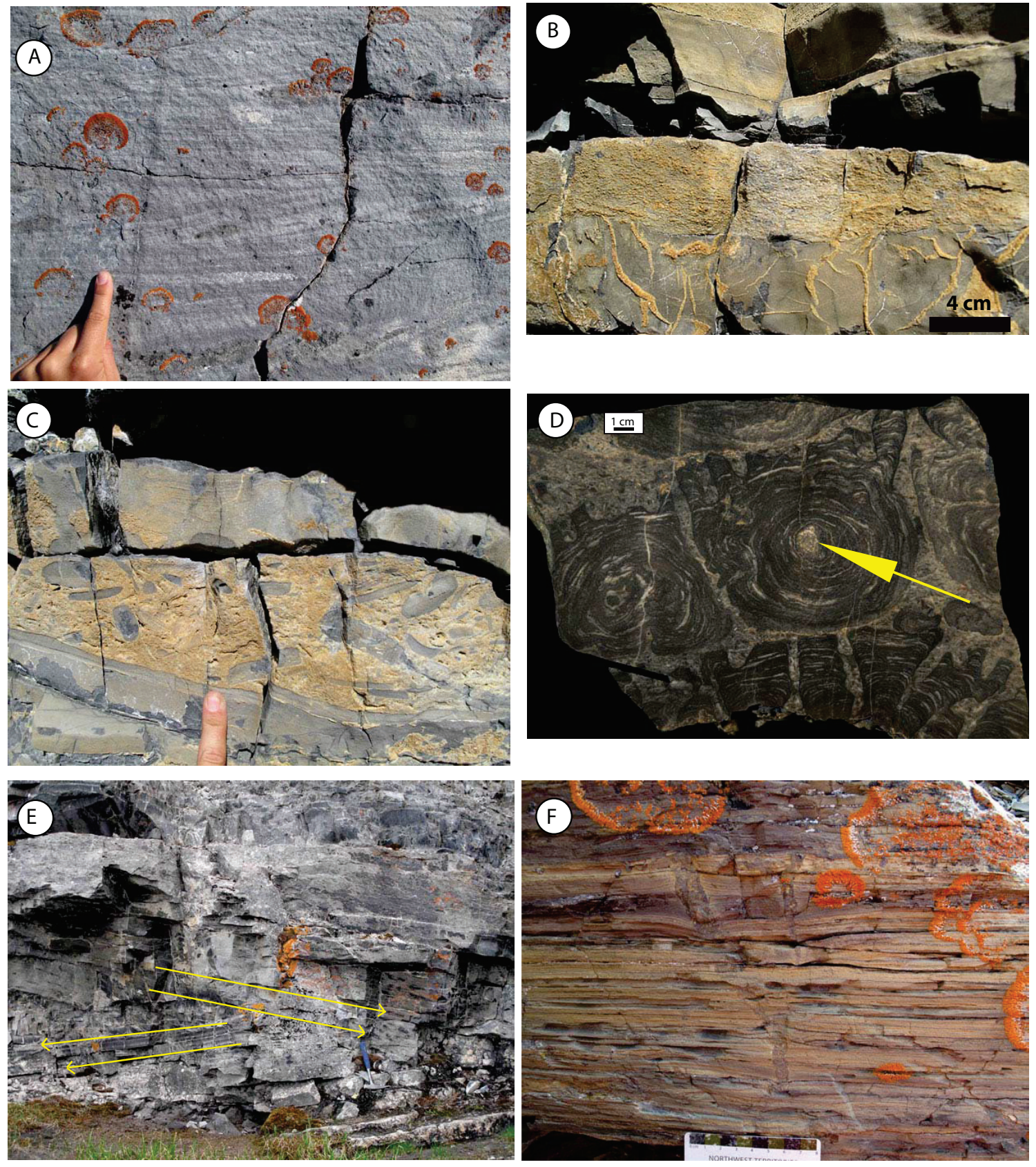

Figure 8. Examples of mid- to inner ramp facies. Hammer is $30 \mathrm{~cm}$ long. A) Cross-bedded intraclast grainstone facies (F10). B) Molar-tooth clast packstone facies (F9). C) Lithoclast floatstone with grainstone matrix facies (F11). D) Polished slab of oncoid-digitate stromatolite facies (F12). Note the yellow arrow points to a broken piece of stromatolite that the oncoid is nucleated on, and that digitate stromatolites grew upward (toward top of photo) from the top of the oncoid. E) Cross-bedded peloid grainstone facies (F14). Note the apparent bi-directionality of the cross-beds shown in this photo (arrows). F) Dolomitic siltstone with desiccation cracks facies (F15). 
be gradational or sharp. Beds of molar-tooth clast packstone typically are graded and clasts are imbricated. The matrix consists of fine-grained detrital carbonate and microspar cement.

Interpretation.--- The spatial and repetitive stratigraphic association with molartooth mudstone, and the presence of graded texture and imbricated clasts, are taken to identify this facies as subtidal tempestites arising from the erosion and re-working of molar-tooth mudstone. This supports molar-tooth structure as a product of early diagenesis and a process-generated, as opposed to an event-generated, structure (Furniss et al., 1998).

\subsubsection{Cross-bedded intraclast grainstone facies (F10)}

Description.--- Medium-thick beds of HCS, low-angle cross-bedded, trough cross-bedded, and rare swaley cross-stratified (SCS) intraclast grainstone characterize this facies (Fig. 8). Bases of beds commonly are scalloped erosional surfaces. Allochems consist of reworked clasts of molar-tooth microspar, coated grains, peloids, stromatolitic fragments, and rounded lithoclasts of lime mudstone. Grainstones form thick ( $>1$ metre) amalgamated bodies, or thin sheets interbedded with other facies (e.g., facies F8, F9, and F13).

Interpretation.--- Grainstones require constant wave motion for winnowing of mud and reworking of intraclasts. The close association of this facies with molar-tooth mudstones (F8) and tempestites (F9), as well as the preservation of HCS, positions this facies along a hydrodynamic transition from below to above FWWB. This facies is 
interpreted as storm-transported, subtidal sediment, deposited above FWWB. Allochem composition varies depending on adjacent and underlying sediment composition.

\subsubsection{Lithoclast floatstone with grainstone matrix facies (F11)}

Description.--- Lithoclast floatstone with grainstone matrix facies is not abundant in the Wynniatt Formation. Beds are medium-thick and laterally continuous with erosive bases (Fig. 8). Lithoclasts are usually tabular, gravel sized, and subrounded with variable lithologies, including calcilutite, calcisiltite and ooid grainstone. Grainstone allochems variously include peloids, pisoids and rare ooids. Lithoclasts may be imbricated or randomly oriented and grading is faintly distinguishable in some beds. Rounded quartz sand grains are present locally.

Interpretation.--- Beds of lithoclast floatstone with grainstone matrix facies are interpreted as storm lags. Increased wave action during storms eroded proximal shallow water sediments, scouring into beds and re-depositing lithoclasts. Ooids are rare throughout the Wynniatt Formation; conditions must not have been conducive to their growth. This facies is interpreted as a shallow, grain-rich, subtidal flat that episodically experienced large storms. This facies is similar to intraclast flat-pebble conglomerate subfacies described by Clough and Goldhammer (2000), from the Neoproterozoic Katakturuk Dolomite in Alaska.

\subsubsection{Oncoid-digitate stromatolitic dolostone facies (F12)}


Description.--- This facies is unique to the Stromatolitic Carbonate member. It forms an up to $40 \mathrm{~m}$-thick buildup and can be traced along strike for hundreds of kilometres. There is a consistent vertical succession within the buildup from an assemblage of giant oncoids and branching columnar stromatolites at the base, to narrower, rarely branching, digitate stromatolites at the top. Oncoids are up to $20 \mathrm{~cm}$ in diametre, and are cored by broken pieces of stromatolite (stromaclasts). Some oncoids have digitate stromatolites branching from them (Fig. 8). Intercolumnar space is grainstone composed of stromaclasts, composite pisoids, and ooids.

Interpretation.--- This facies was deposited in a high-energy environment dominated by wave action that liberated coin-sized pieces of stromatolite that became nucleii for the growth of oncoids. Hydrodynamic conditions were energetic enough to keep large oncoids in motion. When oncoids became lodged, they served as a substrate for new stromatolite growth. That stromatolite laminations can be traced around oncoids leads to the inference that the microbial community that composed the oncoids was the same as that of the stromatolites. Comparable facies have yet to be described from the Shaler Supergroup, or from correlative rocks in the northern Cordillera. The depositional facies is interpreted as shallow subtidal, possibly in the wave-break zone.

\subsubsection{Columnar stromatolite facies (F13)}

Description.--- This facies occurs at scales varying from decimetre-thick biostromes to buildups over 10 metres thick. Stromatolite columns generally are $3-10 \mathrm{~cm}$ 
wide and may be solitary or branching (Fig. 9). Stromatolites typically grow as vertical
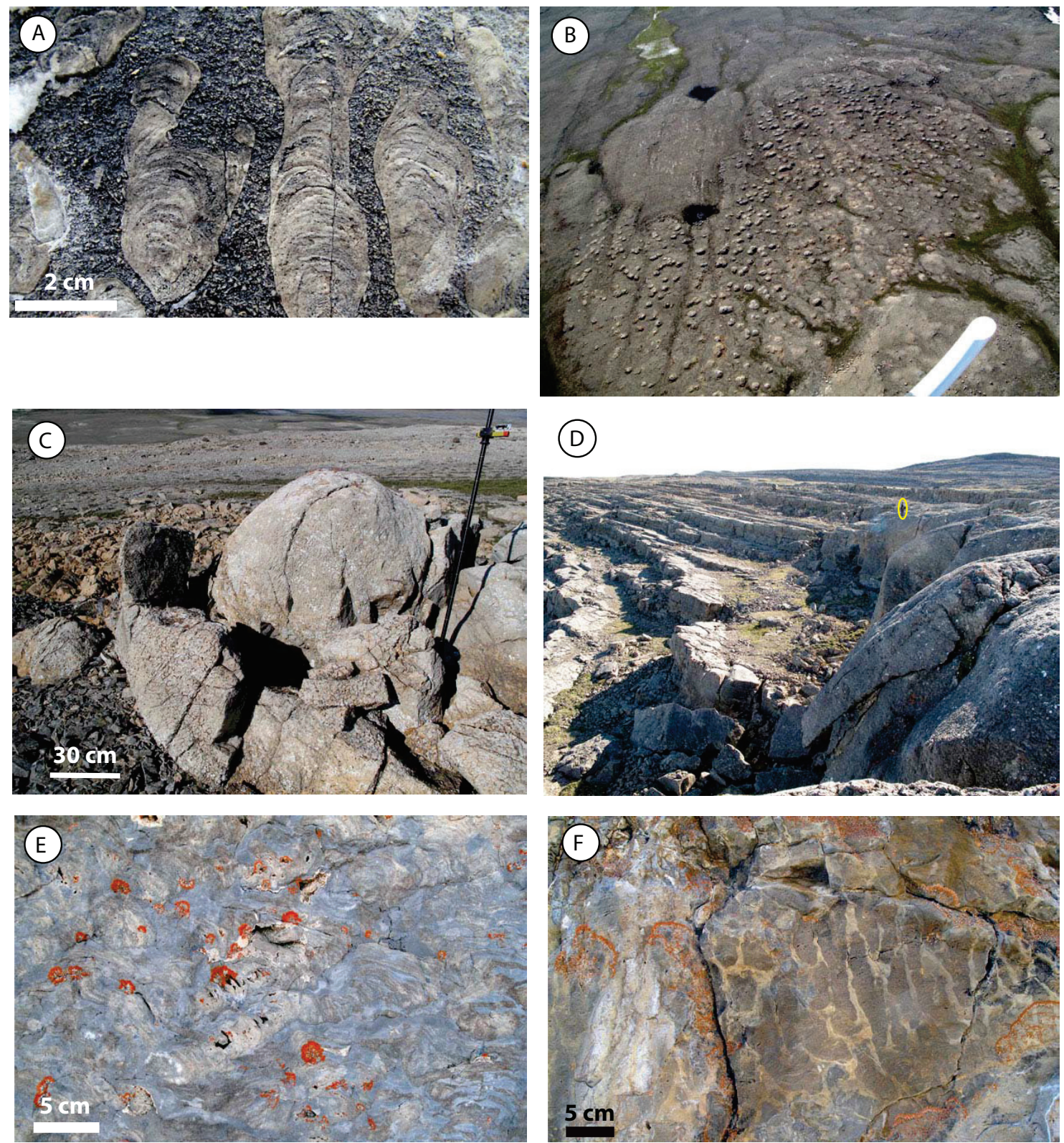

Figure 9. Examples of variation in columnar stromatolite facies (F13). A) Columnar stromatolites with coarse intercolumnar sediment. B) Aerial view of an outcrop of exhumed stromatolite mounds in the Upper Carbonate member. Field of view is approximately $250 \mathrm{~m}$; object in lower right is a helicopter skid. C) Small, domal bioherm of honeycomb-shaped, digitate, unbranching columnar stromatolites. Growth directions range from horizontal at the base to vertical at the top. D) Elongate stromatolitic reef (unbedded area on right side) in the upper carbonate member with flanking, tabular-bedded grainstones. Person circled for scale is approximately $1.5 \mathrm{~m}$ tall. E) Columnar stromatolites in the upper carbonate member, identified as form genus Tungussia? F) Columnar stromatolites in the stromatolitic carbonate member. 
columns, although columns also grew laterally to sub-horizontally. Synoptic relief of individual layers is commonly a few millimetres up to approximately $1 \mathrm{~cm}$, but stromatolite columns grew up to tens of centimeters high. Stromatolites most closely resemble the form genus Tungussia, Acaciella, Baicalia, Jurusania and Tilemsina (Walter 1972; Narbonne, et al. 2000; Kah, et al. 2009). Branching stromatolite forms are variably divergent, both vertically and horizontally. Stromatolites exhibit high morphological variability within this facies (Fig. 9). Bioherms range from tight geometric "honey-comb" shaped mounds with unbranching stromatolites that radiate out from a central core, to irregular petaloid branching forms. Buildups occur as metre-scale isolated mounds, patch reefs, and table reefs. Reefs can be very steep sided $\left(>45^{\circ}\right)$. Reefs may have internal variation or be remarkably homogenous throughout. The lateral extent varies from local to regional, biostromes form resistant benches and thick (decametre) buildups that can be traced across the inlier for hundreds of kilometres. The intercolumnar material may be composed of calcilutite, but more commonly comprises intraclasts, stromaclasts, coated grains, oncoids and lithoclasts, with micritic to blocky calcite cement (Fig. 9).

Interpretation.--- This facies is interpreted to represent a shallow-water, subtidal, inner ramp environment containing stromatolite buildups. Localities with an upward succession of morphotypes from unbranching to branching columnar stromatolites are interpreted to identify a gradational change from a deeper to shallower water environment.

This facies is spatially associated with crossbedded intraclast grainstone facies (F10), and the coarse interstromatolite sediment suggests constant agitation, indicating 
deposition above FWWB. Some buildups were successful in forming hydrodynamic barriers resulting in back-barrier lagoons, but most are encased in grainstones. Similar facies and stromatolite morphotypes have been described from the underlying Boot Inlet Formation (Narbonne et al., 2000) and from the correlative Little Dal Group in the northern Cordillera (Batten, et al. 2004).

\subsubsection{Cross-bedded peloid grainstone facies (F14)}

Description.--- This facies is associated with the domal stromatolite facies (F16 see below) and is characterized by medium to thick, wedge-planar to tabular-planar cross-bedded peloidal intraclast grainstone. Low-angle crossbedding and planar stratification also are preserved. Adjacent sets of cross-beds have foresets with apparent opposed (bidirectional) transport (Fig. 8). Allochems are predominantly peloids, with subordinate micritic lithoclasts and rare fine-grained quartz sand grains.

Interpretation.--- Transverse sand waves superimposed on tidal bars resulted in wedge-shaped, dune cross-bedded grainstones. Planar stratification as a result of upperflow-regime storm currents planed the tops of tidal cross-beds. Clough and Goldhammer (2000) described a similar facies from Neoproterozoic carbonate rocks in Alaska. They interpreted their facies as linear tidal sand bars. The wedge-shape geometry and bimodalbipolar crossbeds supports an interpretation that this facies defines an inner ramp, linear tidal sand bar. 


\subsubsection{Dolomitic siltstone with desiccation cracks facies (F15)}

Description.--- This facies occurs exclusively in the Stromatolitic Carbonate member and is located stratigraphically above and adjacent to facies F13. It consists of red, plane-laminated to thin-bedded siltstone. Green redox alteration occurs along fractures. Desiccation cracks are common and are filled with fine-grained, well-sorted, sub- to well-rounded quartz sand (Fig. 8). Thin interbeds of massive quartz arenite are preserved, along with thin mud-clast breccias.

Interpretation.--- The lack of tractional sedimentary structures and presence of regular laminations with desiccation cracks imply a quiet-water, protected environment that was subject to periodic subaerial exposure. Terrigenous sedimentation contributed red mud and silt to the lagoon. Desiccation cracks are filled with sand that was periodically blown in to the lagoon. Eolian sand is also preserved as thin interbeds in siltstone. This facies is interpreted to have been deposited in a protected setting, such as a shallow lagoon that developed behind a stromatolite reef (F12). This back-barrier system can be traced for more than $200 \mathrm{~km}$ along Minto Inlier.

\subsubsection{Domal stromatolite facies (F16)}

Description.--- Domal stromatolites occur mainly in the Upper Carbonate member forming laterally linked (Logan, 1964) or isolated mounds with generally low relief $(<1$ metre) (Fig. 10). Forms are elongate, bun shaped, or undulatory. Isolated domal stromatolites are encased in crossbedded carbonate sand and parallel-laminated 
lime mudstone. Isolated mounds have channels between them.
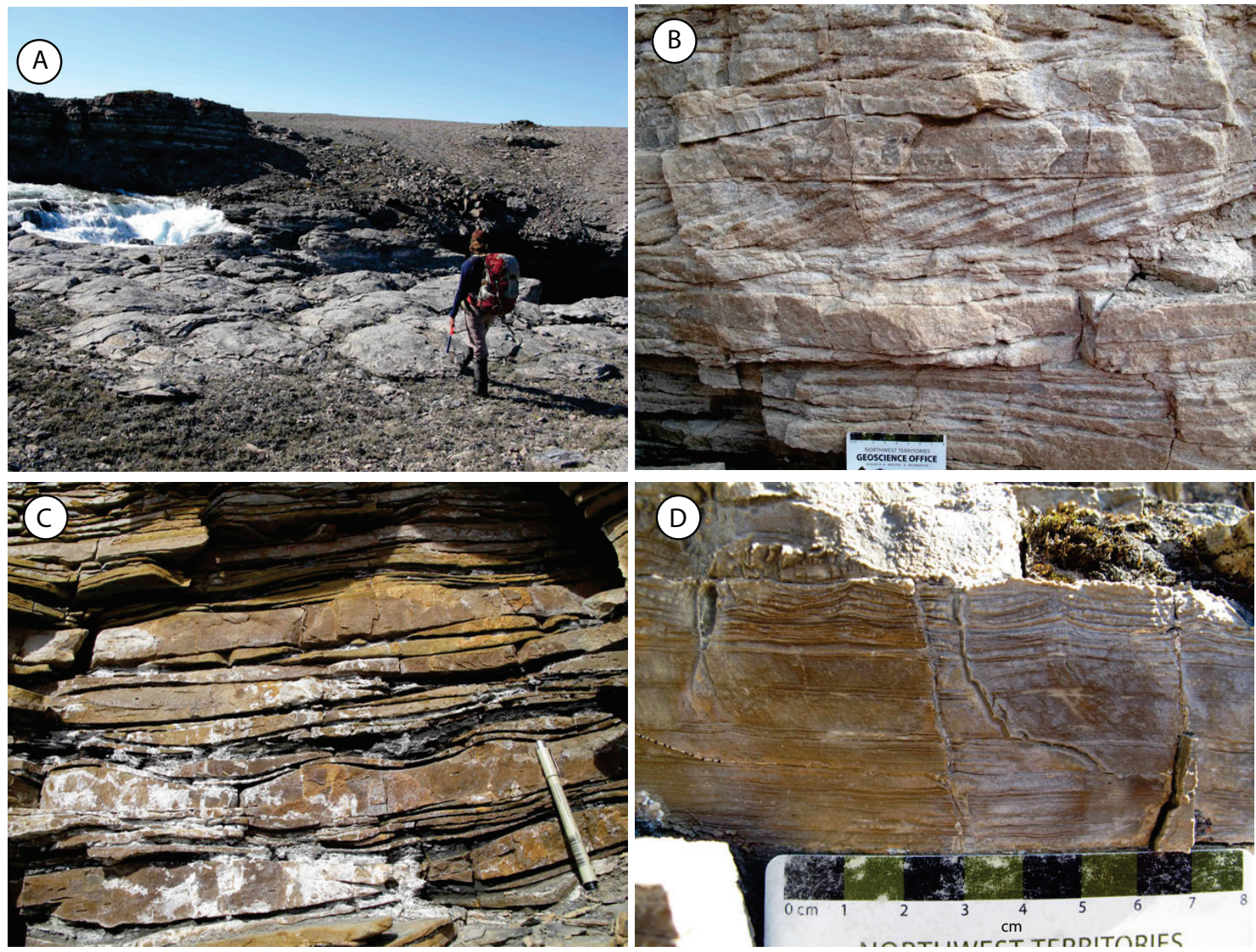

Figure 10. Examples of inner ramp facies. A) Domal stromatolite facies (F16). Bedding surface of laterally linked hemispheroid stromatolites. B) Cross-bedded quartz-arenite facies (F17). C) Flaser-lenticular bedded, quartzose dolosiltite and dolarenite facies (F18). D) Laminated lime/dolomudstone facies (F19). Scale card in B and D is $8 \mathrm{~cm}$ wide.

Interpretation.--- Elongation of domal stromatolites in some localities may identify influence from tidal currents and/or prevailing wave directions (Logan, et al. 1974). Domal stromatolites are interpreted as intertidal (Logan et al. 1964).

\subsubsection{Cross-bedded quartz-arenite facies (F17)}


Description.--- This facies consists of beige, fine- to medium-grained, wellrounded, well-sorted, quartz arenite. In thin section, grains are cemented by syntaxial quartz overgrowths. Strata are commonly thin- to medium-thick bedded with herringbone crossbedding. Crossbedding is predominantly planar-tabular but trough crossbeds are also preserved (Fig. 10). At one location, five paleocurrents measurements define a bimodal distribution of approximately $354^{\circ}(\mathrm{n}=2)$ and $102^{\circ}(\mathrm{n}=3)$.

Interpretation.--- Orthogonal paleocurrent directions are likely the result of competing wave and bottom currents. This facies may represent an interval where sedimentation rates were low and sand could be continually washed back and forth, rounding sand grains and winnowing mud. High textural and compositional maturity suggests either lengthy reworking, or derivation from eolian beach dunes. Herringbone crossbedding identifies reworking by tidal currents. Cross-bedded quartz-arenite facies is interpreted as intertidal to subtidal sand bars.

\subsubsection{Flaser-lenticular bedded, quartzose dolosiltite and dolarenite (F18)}

Description.--- Quartz-sandy dolarenite and dolosiltite are interbedded with dark grey silty shale and preserve flaser-lenticular bedding (Fig. 10). Sandstone beds commonly are topped by symmetric wave-ripple marks. Dolarenite is preserved in shallow $(<1 \mathrm{~m})$, flat-topped, concave-based, channels that are up to $10 \mathrm{~m}$ in lateral extent. Gutter casts, ripple crosslamination, and trough crossbedding are also preserved in this facies. Paleocurrents measured from crossbedding average $025^{\circ}(\mathrm{n}=2)$ and $230^{\circ}(\mathrm{n}=3)$, suggesting a bimodal-bipolar distribution. 
Interpretation.--- Flaser-lenticular bedding has long been interpreted as tidal in origin (Reineck and Wunderlich 1968). Sand transported from tidally generated currents is ripple crosslaminated with opposing paleocurrents, and is coupled with mud flasers that settled out in ripple troughs during slack periods between tides. Channel sandstones represent storm deposits re-worked by tidal currents. Bimodal-bipolar paleocurrents and flaser-lenticular bedding support high-energy deposition on an intertidal flat.

\subsubsection{Laminated lime/dolomudstone facies (F19)}

Description.--- This facies consists predominantly of microbially, and less commonly traction-laminated dololutite and calcilutite. Sedimentary features include desiccation cracks, teepee structures, and intraclast breccia (Fig. 10). Desiccation cracks are filled with quartz sandstone, microbially laminated dolostone or mud intraclasts, and microspar cement. Some intervals of dololutite preserve randomly oriented, approximately $2-5 \mathrm{~mm}$ long, lathe-shaped molds that appear to be of similar shape to gypsum crystals. Black chert in the form of nodules or replacement along laminae is preserved in this facies. Well-rounded, frosted quartz sand grains occur in some beds. Microscopically, microbial mats have dissolution voids that are filled by dolomite cement and later replaced by ferroan calcite.

Interpretation.--- This facies represents deposition along a shallow intertidal to supratidal evaporative mudflat. Sediments were periodically flooded during storms and high tides to wet and maintain growth of microbial mats and transport carbonate mud. However, mud flats were also periodically exposed long enough to dry and form teepees 
and desiccation cracks. Intraclast breccias represent storm rip-up deposits. Gypsum formed displacive intrasediment crystals prior to lithification and dissolved during diagenesis. Frosted quartz sand grains were blown onto the tidal flat by wind. Early diagenetic chert is common in Proterozoic tidal flats (Pratt 2010); the chert in this facies is black because it preserves organic material present in the original sediment. 


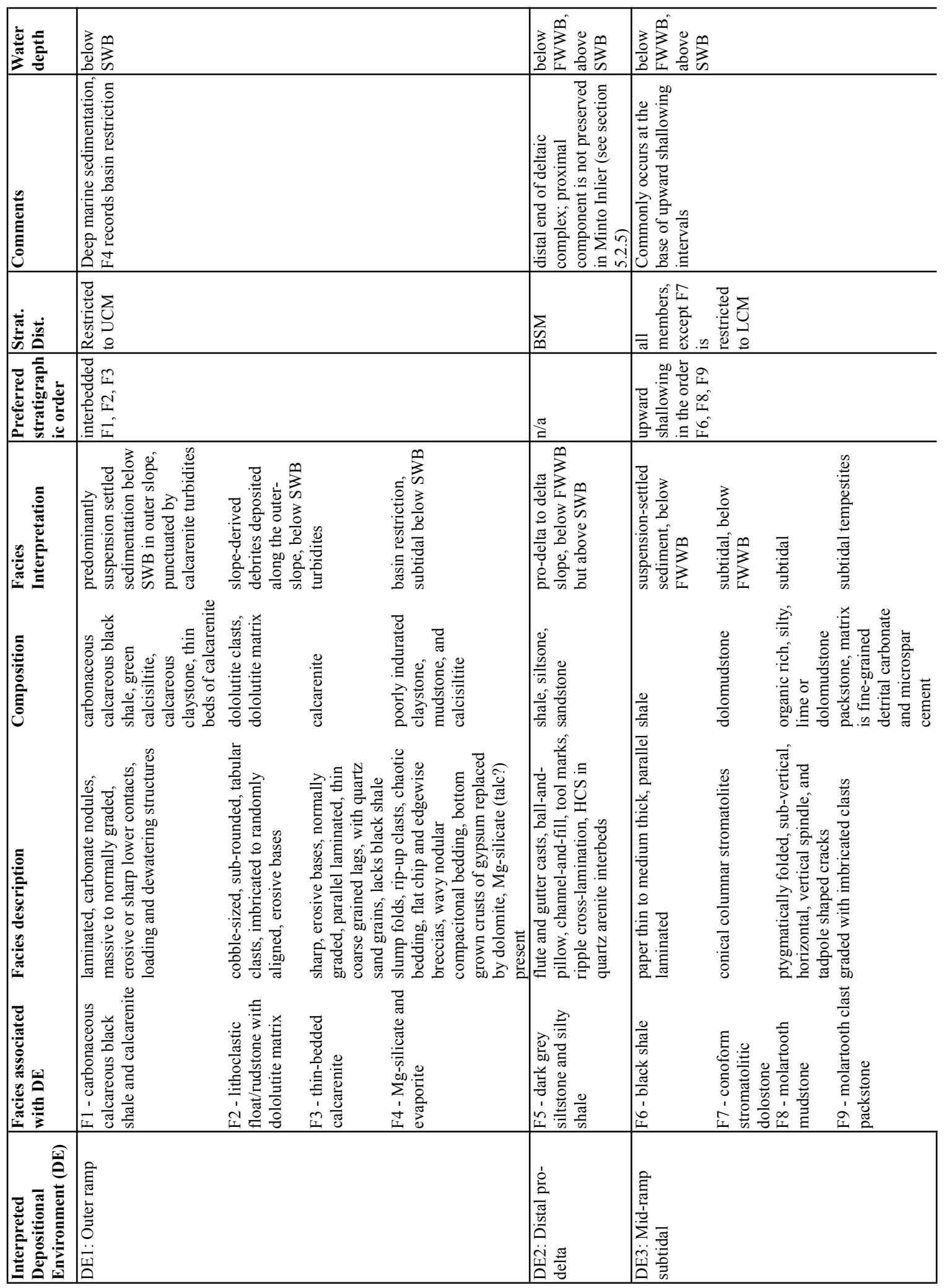

Table 2. Depositional environments and facies of the Wynniatt Formation. 


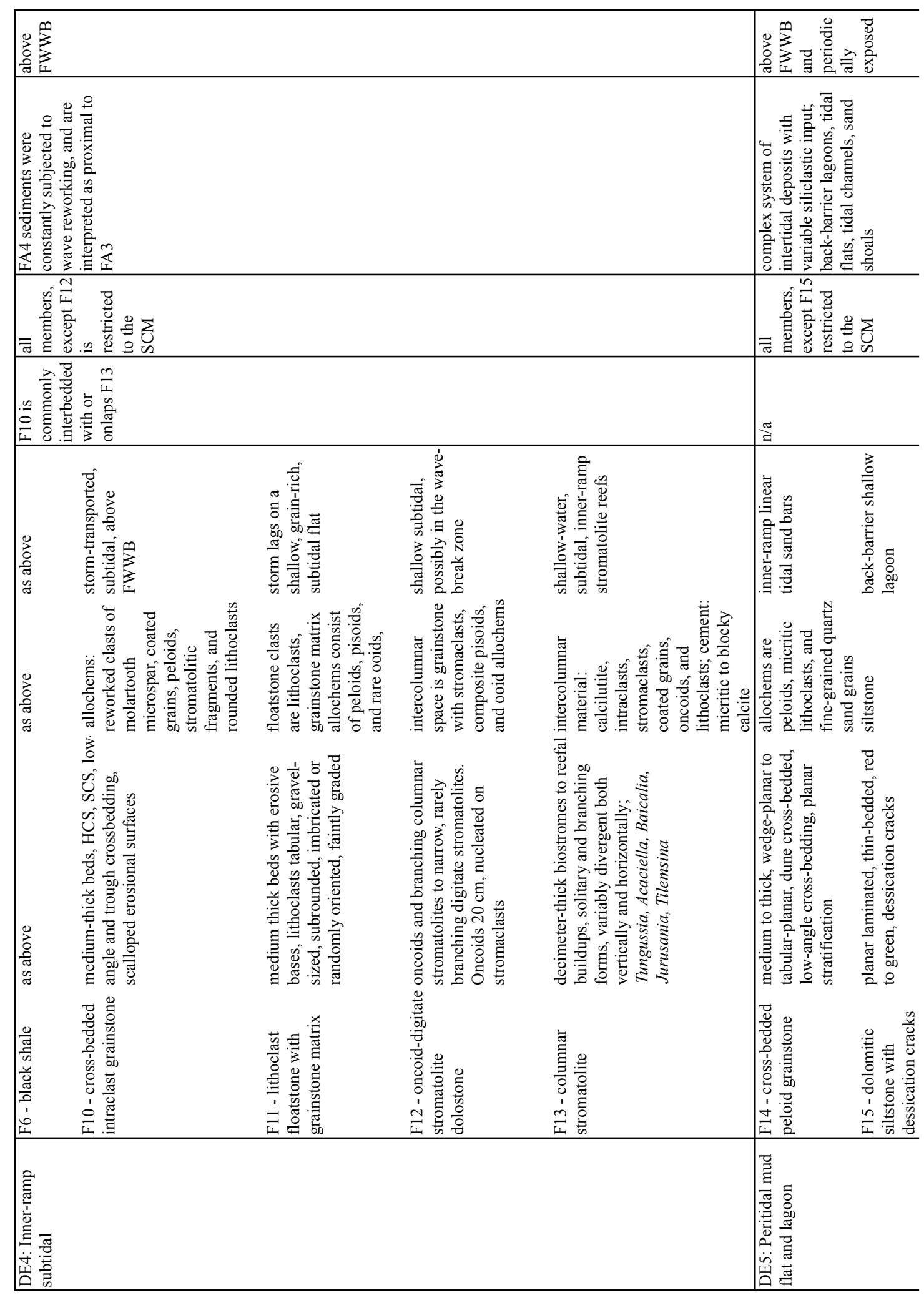

Table 2 cont'd. 


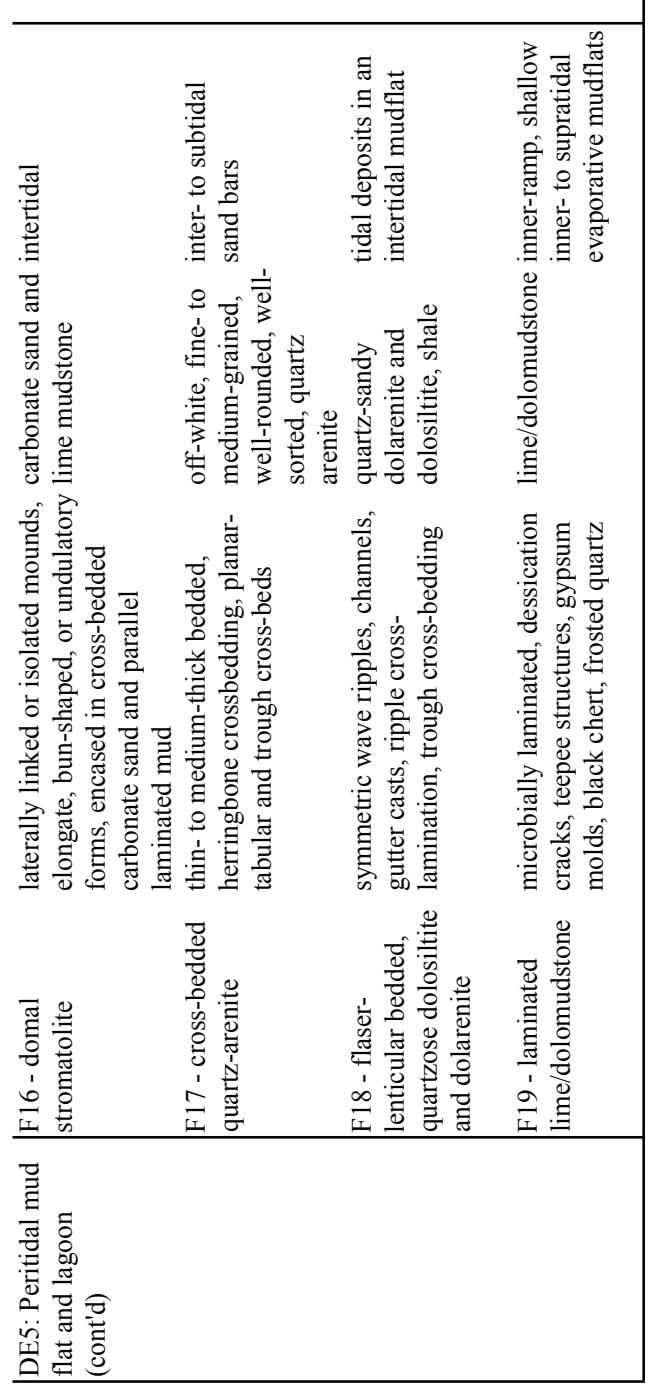

Table 2 cont'd. 


\subsection{Interpretation}

\subsubsection{Depositional Framework Interpretation}

The nineteen lithfacies described above collectively record deposition from five depositional environments (DE1 - DE5, Table 2, Fig. 11). These characterize deposition on a storm dominated, distally steepened ramp, which deepened to the northwest (present coordinates) (Rainbird et al., 1996). Ramp divisions discussed below are based on the classification of Burchette and Wright (1992), whereby the division between inner and mid-ramp is defined by fair-weather wave-base (FWWB), and between mid- and outer ramp by storm wave base (SWB) (Fig. 11). Defining criteria that led to the classification of a ramp depositional system for the Wynniatt Formation include the lateral continuity of facies for hundreds of kilometres and the absence of any facies that suggest build-up of an extensive, steep-sided, rimmed platform. In localized areas the columnar stromatolite facies (F13) formed buildups with relatively minor ( $<15 \mathrm{~m}$ ) paleotopography (Fig. 10D), however the buildups are neither large, nor extensive enough to have formed a rimmed platform. Despite being an embayment of an epeiric sea, there must have been significant fetch to produce strong, storm-generated currents. The shallow inner ramp was also subject to constant wave agitation, as recorded by sedimentary structures such as wavylenticular bedding and symmetrical ripples (e.g. F18).

An outer ramp setting (DE1, Fig. 11) is characterized by facies consisting of resedimented coarse- and fine-grained lithologies (Table 2), in the Upper Carbonate member. This is marked by carbonate sediment introduced to the basin via gravity flow 
deposits. The intraformational composition of clasts (Fig. 6) suggests that these deposits
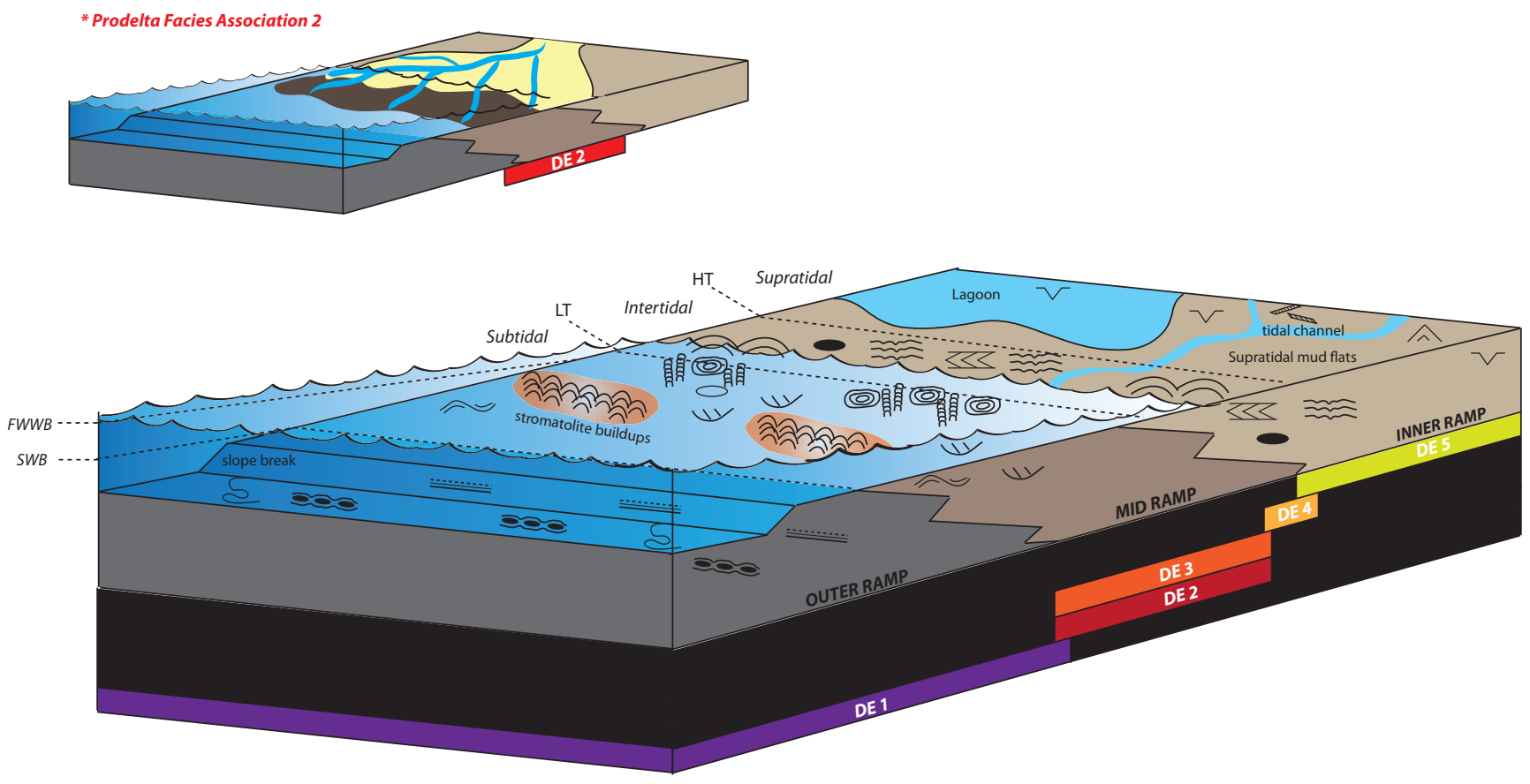

Figure 11. Block diagram showing the generalised distribution of facies assemblages from inner to outer ramp. There is considerable heterogeneity in the inner ramp, with lagoon, supra- and intertidal mudflats, tidal creeks, and sand shoal depositional environments. Mid-ramp deposits include stromatolite buildups. The ramp is distally steepened, as indicated by the slope break on the outer ramp. The inset shows DE2, when the development of a delta drowned the carbonate factory with an influx of siliciclastic sediments.

incorporated only slope-derived sediment, supporting not only the presence of an increased gradient in a seaward position, but the initiation of gravity flows below that oceanographic break. Calcarenite turbidites (F3) stratigraphically overlie strata of lithoclastic float/rudstone facies (F2) in an upward-shallowing succession in the Upper Carbonate member.

A pro-delta depositional environment (DE2, Fig. 11) is proposed for the Black Shale member, which is characterized by siliciclastic shale and siltstone facies (Table 2, 
F5). This might represent a carbonate ramp bypass system, or a period in which a siliciclastic system replaced the shelf carbonate factory (Fig. 11). During this time, the increased supply of siliciclastic sediment overwhelmed carbonate production. We interpret a river-fed delta environment as opposed to a muddy terrigenous shelf to provide a mechanism of transport of siliciclastic sediment. Sediment accumulated in a mid-ramp setting at water depths below FWWB but above SWB.

Mid-ramp deposits are preserved throughout the Wynniatt Formation in DE3 (Fig. 11), represented by lithofacies F6 to F9 (Table 2, Figs. 7 and 9). They are best preserved at the base of upward-shallowing intervals (Fig. 5) where they are overlain by inner ramp, crossbedded intraclast grainstones (F10). Grainstones require constant wave-motion for sediment winnowing and reworking, and therefore strata of facies F10 are interpreted to straddle the mid-to-inner ramp transition where sediments were consistently above FWWB but still closely associated with mid-ramp facies deposited below FWWB.

A regional inner ramp subtidal environment (DE4), represented by facies F6 and F10 to F13 (Table 2, Figs. 8 and 9) and a peritidal mudflat and lagoon environment (DE5), represented by facies F14 to F19 (Table 2, Figs. 8 and 10) constitute the principal inner ramp deposits of the Wynniatt Formation (Fig. 11). It is in the inner ramp where the regional development of columnar stromatolite buildups (F13) is best preserved (Figs. 9 and 11). The oncoid-bearing facies (F12) also forms a laterally extensive barrier system, and is a useful stratigraphic marker in the Stromatolitic Carbonate member. These facies represent a biophysical response to the offshore-nearshore oceanographic transition that characterizes a ramp because there is no seaward impediment to open ocean energy (James et al., 2010). The above intertidal and subtidal facies illustrate development of an 
inner ramp, mixed siliciclastic-carbonate system, with evidence of wave and tidal current influence. The variety of facies illustrates a mosaic of depositional systems including back-barrier lagoons and supratidal to intertidal flats with tidal channels and sand shoals (Fig. 11).

\subsubsection{Ramp Evolution of the Wynniatt Formation}

Spatial (vertical, lateral) arrangement of facies in each of the stratigraphic members of the Wynniatt Formation demonstrates a punctuated evolution of carbonate ramp development. The lower Lower Carbonate member preserves an upward-shallowing succession of peritidal mudflat and lagoon (DE5) deposits. The upper Lower Carbonate member is an upward-deepening succession of mid-ramp deposits consisting of mid- and inner ramp subtidal (DE3 and DE4) paleoenvironments. The top of the Lower Carbonate member is marked by a biostrome of conoform stromatolitic dolostone facies (F7), signaling drowning of the ramp. Carbonate production was then suppressed by deposition of shale and siltstone facies of the Black Shale member, interpreted to have been deposited on a pro-delta slope (DE2).

The Black Shale member shallows upward, with a return to carbonate-dominated sedimentation that marks the base of the Stromatolitic Carbonate member. A subaerial unconformity is preserved near the base of the Stromatolitic Carbonate member (Fig. 4). It caps an interval of orange-weathered stromatolitic dolostone and dololutite, the surface of which is irregular, undercut and irregularly pitted suggesting there was karstification. Overlying this, a thin bed of quartz arenite is locally distributed and contains a lag of 
pebbles and cobbles derived from the underlying stromatolitic dolostone and dololutite. This records a subsequent transgression leading to deposition of overlying inner ramp lagoonal deposits (facies F15, Table 2).

The initial inner ramp deposits are predominantly intertidal with evidence of desiccation (i.e., facies F15 and F18). The overlying and regionally distributed ( 30-mthick) oncoid-stromatolite facies (F12) records initial deepening. Above this marker bed are several cyclic intervals of upward-shallowing, subtidal to peritidal, mid- to inner ramp (DE3, DE4, and DE5) deposits (Figure 11; Table 2). The contact of the Stromatolitic Carbonate member and Upper Carbonate Member is a deeply $(\sim 75 \mathrm{~cm})$ scoured unconformity that defines a major shift from inner to outer ramp deposition (DE1).

The lower $\sim 50 \mathrm{~m}$ of the Upper Carbonate member consists of deep-water, black calcareous shale facies (F1), followed by an interval of Mg-silicate and evaporite facies (F4), which identifies a period of basin restriction. An overlying $\sim 60 \mathrm{~m}$ succession of calcarenite turbidites (F3) signals a return to open ramp circulation and downslope transport. The remaining upper half of the Upper Carbonate member contains cyclical deposits of mid- to inner ramp DE3, DE4, and DE5 (Table 2).

The duration of carbonate ramp development preserved by the Wynniatt Formation js poorly constrained, but represents at least 50 million years (van Acken et al., 2013; Fig. 1). As a result, the two prominent intraformational unconformities probably separate three different ramp successions, where each break represents a significant hiatus and re-arrangement of ramp architecture. The lower ramp succession comprises the Lower Carbonate and Black Shale members. It defines a gentle slope that 
preserves a transgression succeeding basin-central evaporites of the underlying Minto Inlet Formation, leading to development of pro-delta siltstone strata of the Black Shale member. The second ramp succession comprises most of the Stromatolitic Carbonate member, and preserves a series of upward-shallowing cycles of subtidal, mid- to inner ramp deposits (facies F8, F10, F13, and F19). The third ramp succession, represented by the Upper Carbonate member, preserves an outer distally steepened ramp that shallows upward to an inner ramp, and preserves the steepest and most variable slope gradient. While still technically a ramp, lithofacies in the outer ramp depositional environment (F2 and F3; Table 2) provide evidence that it is distally steepened. As well, there are steepsided stromatolitic patch reefs that formed in a subtidal inner ramp setting (Fig. 9), which may be recording the early stages of transition to a rimmed platform.

\subsubsection{Ramp Architecture and Basin Subsidence}

The Amundsen Basin is envisaged as an embayment separated from the Mackenzie Basin by a promontory, the Great Bear Arch (Fig. 12; Young, 1977; Young, 1981; Rainbird et al., 1996). Paleogeographic data from strata in the Mackenzie Mountains indicate a southwesterly deepening basin marginal to the north-northeasterly curvilinear Ogilvie-Mackenzie platform (Aitken and Long, 1978; Turner and Long, 2008). In contrast, the platform faces north-northwest in the Amundsen Basin (Young, 1977; Rainbird et al., 1992). A northwest-protruding promontory, dividing, but not separating the Ogilive-Mackenzie and Amundsen platforms, is supported by geophysical data (Aitken and Pugh, 1984; Aspler et al., 2003). This arch was the zero-edge of 
deposition along the south-southwest oriented margin of the Amundsen Basin. The

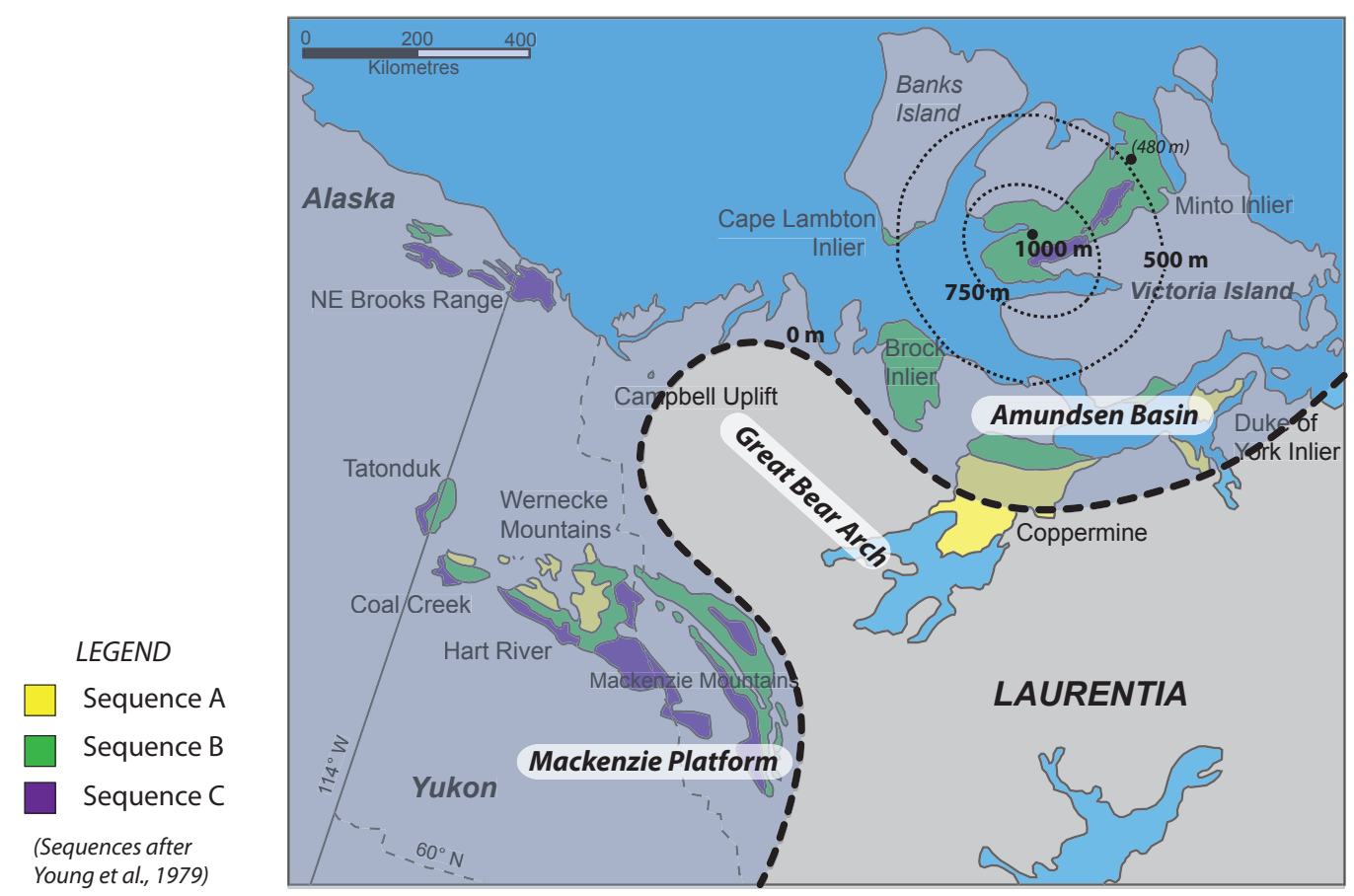

Wynniatt Formation

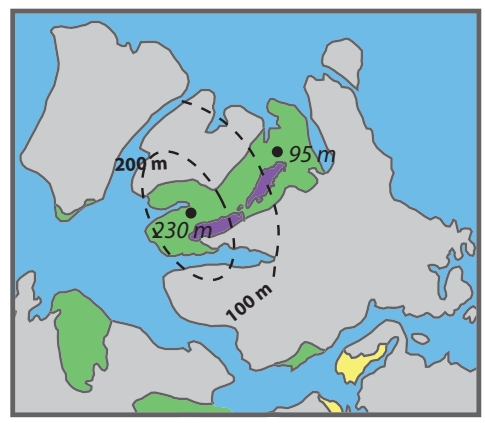

Ramp Time 1 (LCM + BSM)

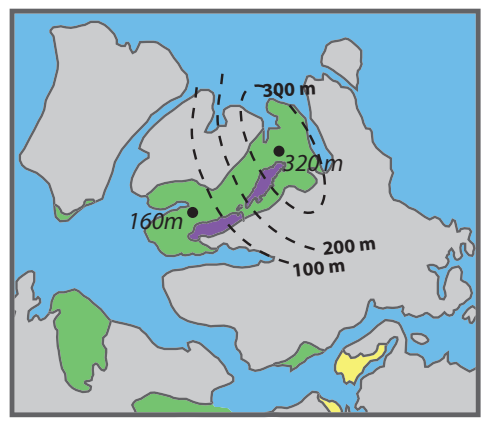

Ramp Time 2 (SCM)

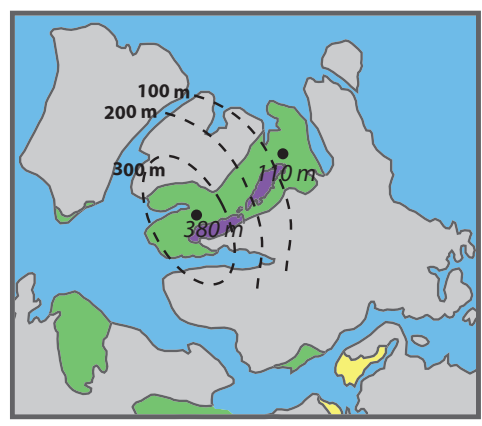

Ramp Time 3 (UCM)

Figure 12. Isopach maps of sediment thickness. Top map shows the paleogeography of northwest Laurentia during deposition of the Wynniatt Formation, modified from Rainbird et al. (1996). The grey area represents land, the blue is water. The estimated zero edge of deposition is shown along the approximate location of the Great Bear Arch; the thickest accumulation of sediment is in the southwest of the Minto Inlier, which thins towards the northeast, forming an interpreted concentric pattern. The bottom three inset maps show migration of the depocentre location during the three different ramp successions of the Wynniatt Formation, where accumulation was thickest in the southwest during deposition of the Lower Carbonate member (LCM) and Black Shale member (BSM) and Upper Carbonate member (UCM), and thickest in the northeast of Minto Inlier during deposition of the Stromatolitic Carbonate member (SCM). All of the dashed lines shown are interpretive, there is no direct field evidence to draw isolines as they are shown, however they are best-guess estimates given the geology and known thicknesses. 
greatest accumulation of Wynniatt Formation strata is preserved in southwestern Minto Inlier (Fig. 12), with thinning toward the northeast. Thus, the depositional pattern of the Wynniatt Formation in the Amundsen Basin is interpreted as concentric, based on isopachs of unit thicknesses (Fig. 12), analogous in size and shape to Paleozoic intracratonic basins (Howell and van der Pluijm, 1990).

However, regional variations in the thicknesses of stratigraphic units (Fig. 12) indicate that the depocentre of the basin switched from the southwest to northeast and then back to southwest (Fig. 12). The combined thickness of the Lower Carbonate member and Black Shale member (i.e. lower ramp) in the southwest is $230 \mathrm{~m}, 2.5$ times greater than its thickness in the northeast, where it is only $95 \mathrm{~m}$. Opposing this trend, the Stromatolitic Carbonate member (i.e. middle ramp) doubles in thickness from $160 \mathrm{~m}$ in the southwest to $320 \mathrm{~m}$ in the NE. A return to a southwestern depocentre is indicated by the $380 \mathrm{~m}$-thick section of Upper Carbonate member (i.e. upper ramp), which is 3.5 times greater than its thickness in the northeast (110 m; Fig. 12).

\subsection{Discussion}

\subsubsection{Subsidence patterns during deposition of Wynniatt Formation}

A comparison of subsidence history and ramp development in the Wynniatt Formation with the Paleozoic Michigan Basin (Howell and van der Pluijm, 1990) offers 
useful insights for analysis of the Amundsen Basin. There are four distinct episodes of basin subsidence documented for the Michigan Basin that occur on a similar time scale to changes in the Wynniatt Formation, where changes in subsidence are: 1) early extension, 2) basin-centred subsidence, 3) eastward tilting towards the Appalachian orogen, and 4) return to basin central subsidence. Howell and van der Pluijm (1990) propose that these episodic changes in subsidence and basin reactivation in the Michigan Basin are likely related to Appalachian events and the resultant intraplate stress variations.

A similar paleotectonic arrangement places the Amundsen Basin $\sim 3000 \mathrm{~km}$ northeast of the Grenville orogen of southeastern Laurentia. However, the youngest contractional activity in the Grenvillian Orogeny in Laurentia occurred at 1000 - 980 Ma (Hynes and Rivers, 2010), approximately 200 m.y. before deposition of the Wynniatt Formation. Thus, changes in Amundsen Basin subsidence patterns during deposition of the Wynniatt Formation may have been controlled by other far-field stresses that occurred along other contemporaneous, and possibly conjugate margins to Laurentia. For example, during initial rifting of Rodinia, signaled by the emplacement of the Gairdner dyke swarm in Australia at $\sim 827 \mathrm{Ma}$ (Wingate et al., 1998), and the Bikou basalts in South China between 820-810 Ma (Wang et al., 2008). Both events occur on cratons that, in many reconstructions, are adjacent to northwest Laurentia (e.g., Li et al., 2008; Li and Evans, 2011). There is evidence of contemporaneous extension in correlative strata of the Fifteenmile Group (Macdonald et al., 2012) and Mackenzie Mountains Supergroup (Turner and Long, 2008) in the northern cordillera, $>1000 \mathrm{~km}$ to the southwest (Fig. 12). Although basin subsidence in the Paleozoic Michigan Basin is related to collisional events as opposed to what were probably extensional tectonic events in the 
Neoproterozoic Amundsen Basin, there are similar patterns that are repeated in terms of episodic subsidence, migration of depocentres, and ramp dynamics between these different basins.

\subsubsection{Comparison of sedimentary patterns}

Our work provides the first detailed facies and stratigraphic analysis of the Wynniatt Formation, thereby allowing evaluation of intra- and interbasinal comparisons. In the lower Shaler Supergroup of the Minto Inlier, the Boot Inlet Formation (Fig. 1) is a $\sim 500 \mathrm{~m}$ thick carbonate unit, which is also interpreted to have accumulated on a stormdominated carbonate ramp (Young and Jefferson, 1975; Young and Long, 1977; Morin and Rainbird, 1993; Rainbird et al., 1994; Narbonne et al., 2000). There are, however, two prominent differences between the formations. First, unlike stromatolitic buildups within the Wynniatt Formation, which typically formed tabular (biostromal) bodies that can be correlated across Minto Inlier, the Boot Inlet Formation preserves a variety of more isolated (biohermal) reef morphotypes, which include: patch reefs, table reefs, and large concentric-sheet bioherms that are up to $60 \mathrm{~m}$ in diameter (Narbonne et al., 2000). Second, ooids are abundant in the Boot Inlet Formation compared to the scarcity of these allochems in the Wynniatt Formation. There was obviously some important difference in either the paleoclimate and/or seawater chemistry (Lloyd et al., 1987) that favoured ooid production during Boot Inlet time. 
Stromatolite types of the Boot Inlet and Wynniatt formations are similar, comprising Tungussia, Baicalia, and Jurusania; however Acaciella is present only in the Wynniatt Formation. Interestingly, Acaciella has been documented from the correlative Neoproterozoic Amadeus Basin of Australia (Bell and Jefferson, 1987; Rainbird et al., 1996; Hill et al., 2000; Planavsky and Grey, 2008). Specifically, the Acaciella australica stromatolite assemblage (Hill et al., 2000) occurs in the Loves Creek Member of the Bitter Springs Formation, coinciding with a negative carbon isotope excursion (Hill and Walter, 2000; Walter et al., 2000; Swanson-Hysell et al., 2010). This negative excursion has also been reported from the Wynniatt Formation (Jones et al., 2010; Thomson et al., 2012) and has been used for global stratigraphic correlation (Halverson et al., 2007a; Halverson et al., 2010). It is possible that the A. australica assemblage is temporally restricted in the Shaler Supergroup, although this needs to be substantiated.

The striking similarities documented between the Shaler and Mackenzie Mountains supergroups have made for robust, long-standing litho- and sequence stratigraphic correlations (Young et al., 1979; Rainbird et al., 1996; Long et al., 2008). Within that framework, the Wynniatt Formation is correlative to the Snail Spring and Ram Head formations (Turner and Long, 2012). The Snail Spring Formation is equivalent to the Lower Carbonate and Black Shale members, and like in those members, represents shallow-water deposition and shut-down of the carbonate factory, followed by transgression (Aitken, 1981; Turner and Long, 2008). The Ram Head Formation records upward-shallowing intervals of grainstone, molartooth mudstone, and cryptalgal laminite (Aitken, 1981), analogous to the upward-shallowing successions observed in the Stromatolitic Carbonate member. 
Samples containing Tawuia and Chuaria specimens were identified by Hofmann and Rainbird (1995) from northeastern Minto Inlier, near Kilian Lake (Fig. 1). The stratigraphic interval that contains these fossil occurrences is described as "just below and above the contact zone between a distinctive rusty black shale member and the overlying grey dolostone member of the Wynniatt Formation" (Hofmann and Rainbird, 1995, pg. 723). This is also the same stratigraphic interval from which a diverse suite of acritarchs and other organic-walled and filamentous microfossils was described (Butterfield and Rainbird, 1998; Butterfield, 2005). We correlate this stratigraphic interval to the contact between the Black Shale member and the Stromatolitic Carbonate member (Fig. 4). In the Wynniatt Formation, this occurrence of the Tawuia-Chuaria assemblage zone is preserved within a peritidal mudflat and lagoon depositional environment (DE5, Table 2). This supports the original interpretation of Hofmann and Rainbird (1995), that these fossils were preserved in intertidal sedimentary rocks that were periodically subaerially exposed and influenced by storms. The Black Shale member is correlative with the Snail Spring Formation (Rainbird et al., 1996; Turner and Long, 2012), where the TawuiaChuaria assemblage has also been recovered (Hofmann, 1985). Tawuia is also documented from lower in the Mackenzie Mountains Supergroup, in deep-water rhythmites of the Stone Knife Formation (Hofmann and Aitken, 1979; Turner and Long, 2012). Our work improves the depositional and stratigraphic context for this assemblage zone allowing for future greater interbasinal correlations, and improved understanding of paleogeographic distribution of depositional environments. 


\subsection{Conclusions}

This contribution presents new sedimentological descriptions and interpretations for a hitherto undescribed stratigraphic unit. Coupled with spatial organization of depositional environments and their component lithofacies, as well as two prominent, regional unconformities, the Wynniatt Formation represents a succession of three highenergy, distally steepened carbonate ramps. Sedimentation was predominantly controlled by storm-generated processes, with minor reworking by wave and tidal currents. Isopach maps based on sediment thicknesses provide support that the Wynniatt Formation accumulated in a circular basin. Inferred changes in the position of regional depocentres are associated with each stage of ramp development. This is likely the result of far-field extensional stresses, given that the age of the formation overlaps with initiation of breakup of the Rodinia supercontinent, and that extension is manifested as fault-related sedimentation in coeval basins located closer to the paleomargin of Laurentia. Our work provides sedimentary and stratigraphic contexts for intra- and interbasinal correlations; this includes an improved understanding of basin and carbonate-ramp development in the Amundsen Basin, and an improved basis for interbasinal correlation among coeval Neoproterozoic basins. 


\section{CHAPTER 3: TRANSGRESSIVE-REGRESSIVE CYCLES AND TECTONOSTRATIGRAPHY OF THE UPPER SHALER SUPERGROUP}

Thomson, D., Rainbird, R. H., Krapez, B. T-R cycles and tectonostratigraphy of the Neoproterozoic (Tonian-Cryogenian) Amundsen Basin prior to supercontinent (Rodinia) Breakup. In review, re-submitted to GSA Bulletin

\subsection{Introduction}

The Neoproterozoic was a dynamic era in Earth history, during which major changes in the isotopic composition of seawater (e.g. Halverson et al., 2007a), the evolution of early animals (e.g. Morris, 1993), low latitude glaciations (e.g. Kirschivink, 1992), and the formation and breakup of the supercontinent Rodinia occurred (e.g. Hoffman, 1991). Recognition of a late Mesoproterozoic supercontinent evolved from the correlation of sedimentary successions between northwestern Canada and Australia (Eisbacher, 1985; Bell and Jefferson, 1987); and reconfiguration of remnant Grenville terranes (1080 - $985 \mathrm{Ma})$ preserved on several continents (Moores, 1991; Gower and Krogh, 2002; Davidson, 2008). In most reconstructions of Rodinia, Laurentia is interpreted to have formed the core of the supercontinent (e.g. Hoffman 1991; Li et al. 2008). The Amundsen and Mackenzie basins are considered to have been embayments of an extensive epeiric sea that covered northwestern Laurentia during the time between amalgamation and break-up of Rodinia (Fig. 13; Young, 1981; Rainbird et al., 1996). There remains debate about the paleogeographic fit of the continental blocks that surrounded Laurentia, with numerous different models proposed (e.g., Hoffman, 1991; 
Brookfield, 1993; Borg and DePaulo, 1994; Dalziel, 1997; Burrett and Berry, 2000;

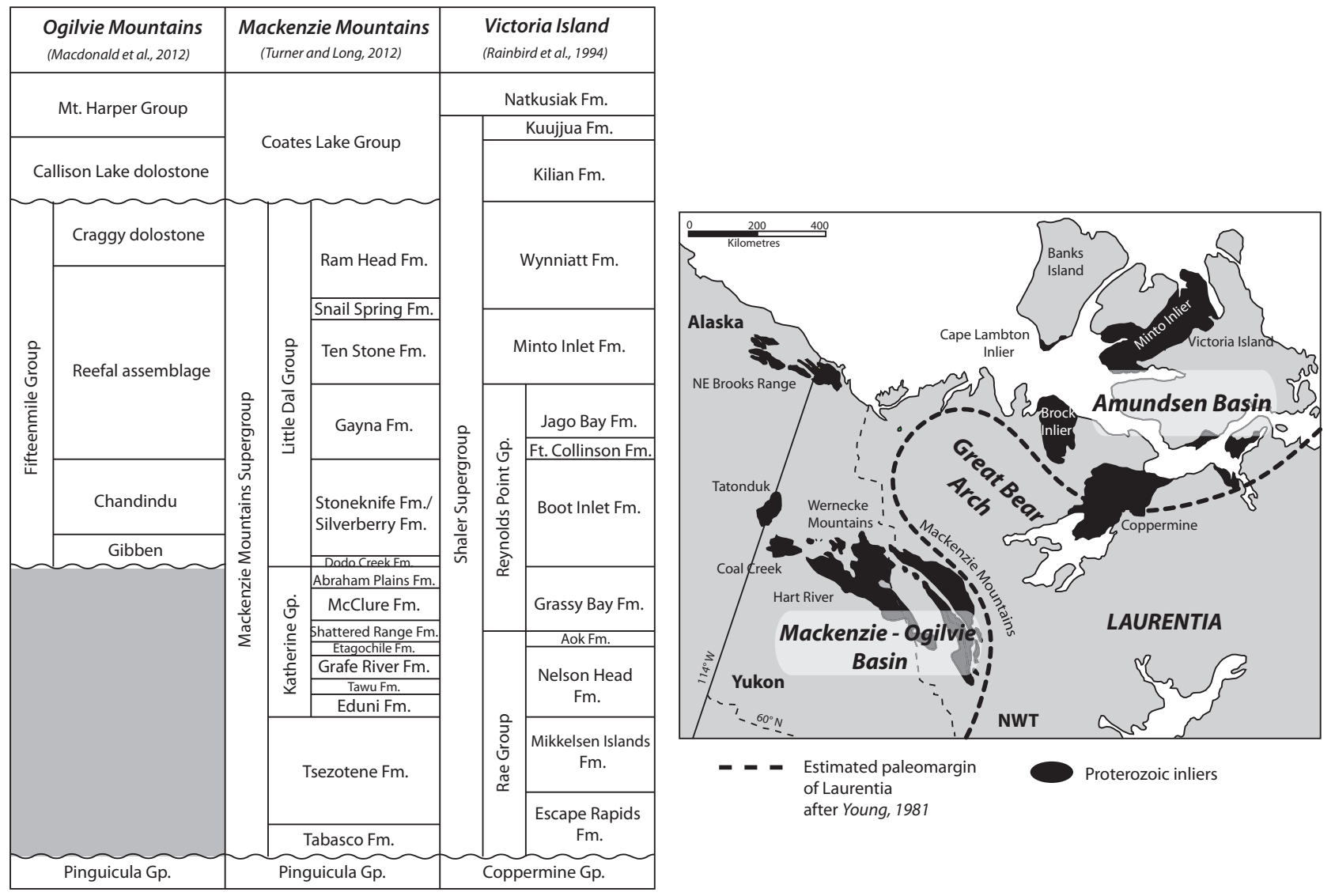

Figure 13. Correlation chart of the Shaler Supergroup (after Rainbird et al., 1994 and references therein), Mackenzie Mountains Supergroup (after Turner and Long, 2012 and references therein), and Fifteenmile Group (after Macdonald et al., 2012 and references therein), and map showing the localities of Proterozoic outcrops (shown in black) in northern Canada and Alaska and the estimated paleomargin of Laurentia (modified from Young et al., 1981).

Wingate and Giddings, 2000; Li et al., 2008; Evans, 2009; Li and Evans, 2011).

Questions also remain about the nature and timing of the break-up of Rodinia, in particular along the northwest margin of Laurentia. Studies of sedimentary rocks in the Ogilvie Mountains, Yukon (Macdonald et al., 2010; Halverson et al., 2012; Macdonald et 
al., 2012), Mackenzie Mountains, Northwest Territories (Turner and Long, 2008), and the Amundsen Basin, Northwest Territories (Rainbird et al., 1996) invoked different models for pre-720 Ma extension in a northwest-southeast orientation. Turner and Long (2008) attributed extension to simple shear, lower-plate upper-plate detachment along transfer faults for the Mackenzie Mountains Supergroup, whereas Macdonald et al. (2012) interpreted normal faults related to extension and to thermal decay of a mantle plume for the Fifteenmile Group. The interpretation of Macdonald et al. (2012) corroborates the interpretation of an intracontinental sag basin for the Shaler Supergroup (Rainbird et al., 1996).

In this paper, we identify several transgressive-regressive (T-R) cycles, which help to provide a tectonostratigraphic framework for a succession in the Amundsen Basin, Northwest Territories (Canada) that corresponds to deposition ca. 900-780 Ma, prior to the breakup of Rodinia. Stratigraphic cycles record global to intrabasinal controls, and can be used to correlate and discriminate among coeval stratigraphic sections in now geographically disparate basins. It is well established that the Shaler Supergroup of the Amundsen Basin records deposition in terrestrial and rhythmically alternating restricted to open-marine conditions (Young, 1981; Rainbird et al., 1996), but stratigraphic division that would better document the causes and responses of cyclic paleoenvironmental changes has previously been attempted only for the Kilian and Kuujjua formations (Rainbird, 1993) and Boot Inlet Formation (Narbonne et al., 2000; Fig. 1).

Pre-breakup successions of intracontinental sag basins have stratigraphic architectures that differ from those of fault-bound rift basins and of passive margins 
where the geometry and architecture of thick prograding sequences can more easily be recognized (Lindsay et al., 1993; Vescei and Duringer, 2003). Sedimentation rates in the Amundsen Basin generally kept pace with, or were briefly outmatched by subsidence, and there is little evidence for large-scale progradation, thereby resulting in a broad layercake stratigraphy. Correspondingly, shallow-water facies predominate and were deposited on gently sloping ramps with little, if any, fault-bound compartmentalization. Assignment of subsidence mechanism, or the recognition that such cycles relate to prerift extension, is difficult. Despite the Amundsen Basin being a broad ( $\sim 300 \mathrm{~km})$, shallow-water basin in which most of the sediments were deposited above storm wavebase (SWB), it is possible to identify cycles and interpret subsidence patterns prior to break-up of Rodinia, which has implications for understanding stratigraphic architecture of other intracontinental sag basins.

\subsection{Regional Geology}

The Neoproterozoic (Tonian-Cryogenian) Shaler Supergroup is over $4 \mathrm{~km}$ thick in the Amundsen Basin (Fig. 1), comprising in ascending order the Rae Group, Reynolds Point Group, and the ungrouped Minto Inlet, Wynniatt, Kilian, and Kuujjua formations. The sedimentary succession is intruded by diabase sills and dykes that fed the Natkusiak flood basalts, part of the $\sim 720$ Ma Franklin Large Igneous Province (LIP) that was related to the rifting and break-up of Rodinia. Depositional ages of sedimentary units in the Shaler Supergroup are constrained by detrital zircon geochronology of sandstones and 
Re-Os geochronology of organic-rich black shale (Fig. 1), but no tuffs have been discovered for precise $\mathrm{U}-\mathrm{Pb}$ dating.

The Shaler Supergoup is exposed in several erosional windows throughout northwestern Canada; namely the Minto, Cape Lambton, Duke of York, Brock, and Coppermine inliers. Our study is of the upper Shaler Supergroup in the Minto Inlier, which exposes a broad northeast-southwest trending, gently dipping, anticline-syncline pair on northwestern Victoria Island, Northwest Territories, Canada (Fig. 1).

Proterozoic stratigraphic successions of northwestern Canada were divided into three unconformity-bounded sequences, termed A, B, and C by Young et al. (1979). The Shaler Supergroup and correlative rocks in the Mackenzie Mountains (Mackenzie Mountain Supergroup) and Ogilvie Mountains (Fifteenmile Group), constitute Sequence B (Fig. 14), deposition of which postdates the end of the Grenvillian orogeny at $\sim 1000$ Ma and predates breakup of Rodinia at $\sim 720$ Ma in northwestern Laurentia (Heaman et al., 1992; Macdonald et al., 2010). There are long-standing lithostratigraphic and sequence stratigraphic correlations among Sequence B strata (e.g., Young et al., 1979; Rainbird et al., 1996; Long et al., 2008). In particular, Long et al. (2008) subdivided Sequence B into five sub-sequences (i.e. sB1 to sB5). In that sequence stratigraphic framework, the Jago Bay Formation belongs to sB3 and the Minto Inlet and Wynniatt formations fall within sub-sequence sB4, which correlate to the Little Dal Group of the Mackenzie Mountains and the upper Fifteenmile Group in the Ogilvie Mountains (Macdonald et al. 2012). Macdonald et al. (2012) documented eight sequences within the 


\section{Fifteenmile Group (Fig. 14), correlating S5 with the Fort Collinson and Jago Bay}
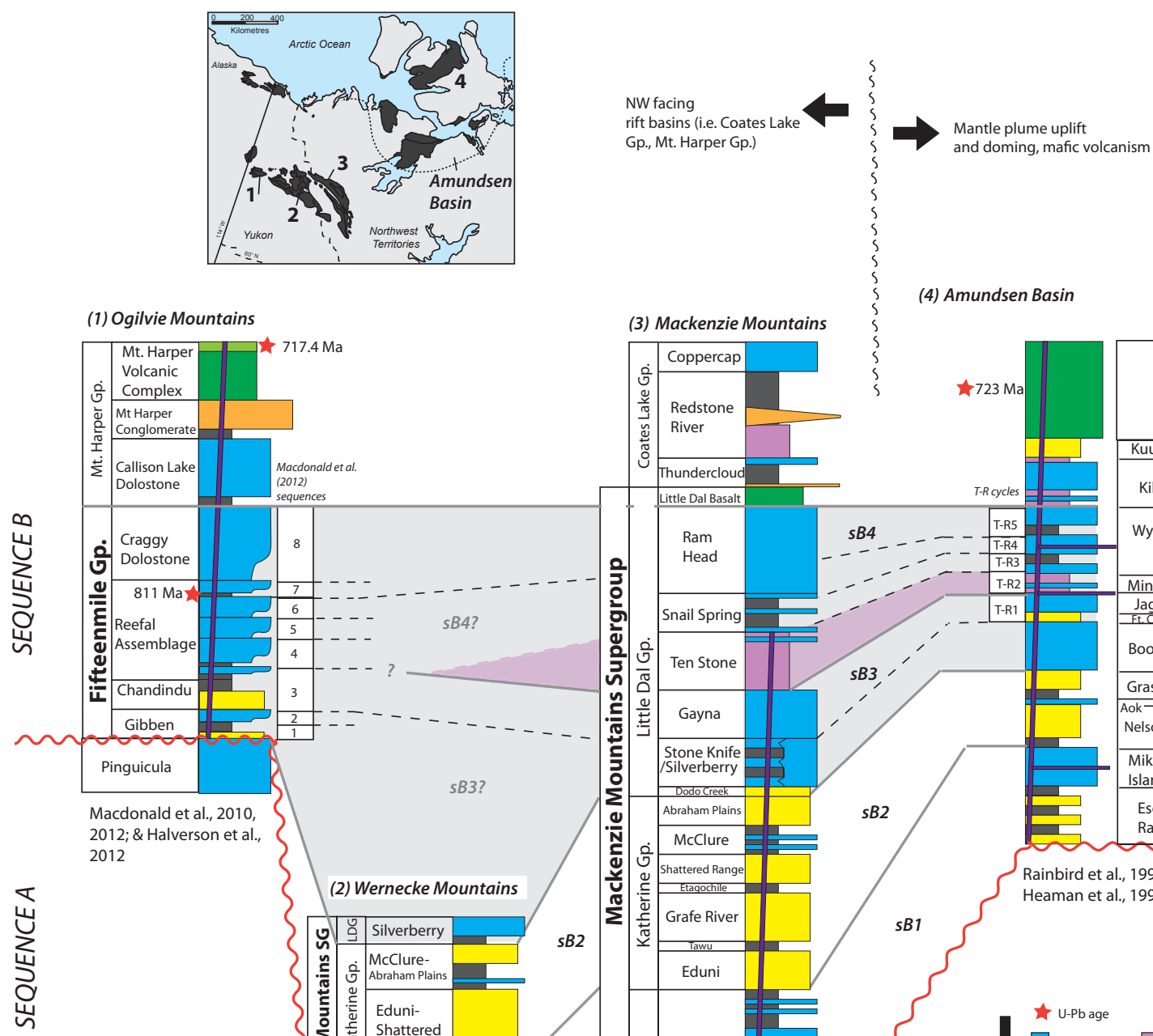

(1) Ogilvie Mountains

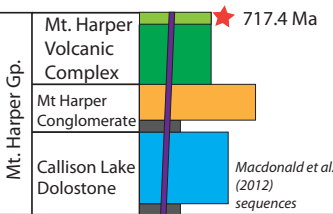

(3) Mackenzie Mountains
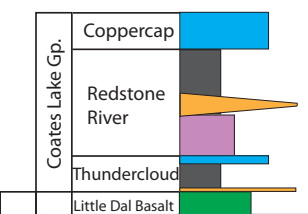

(4) Amundsen Basin

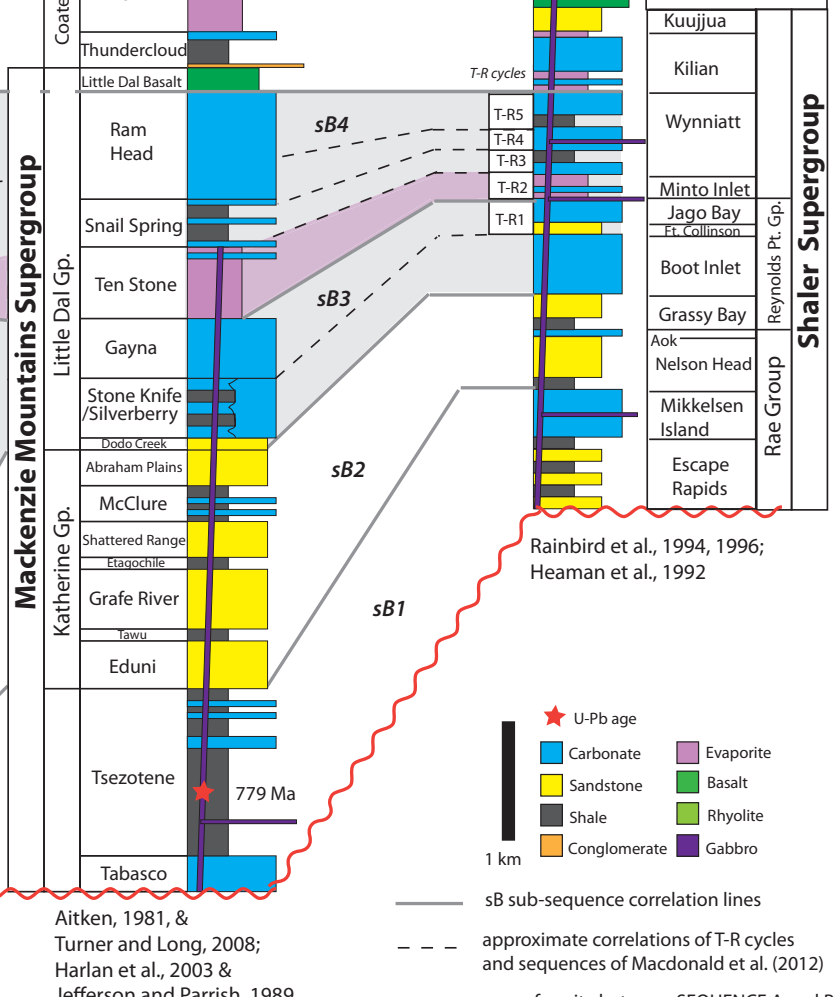

sB3?

Macdonald et al., 2010, 2012

(2) Wernecke Mountains

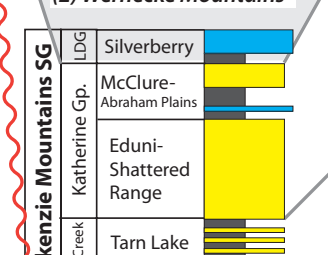

Pinguicula

Jefferson and Parrish, 1989

Figure 14. Correlation of Fifteenmile Group, Mackenzie Mountains Supergroup, and Shaler Supergroup stratigraphy, with sequences indicated. References for stratigraphy and $\mathrm{U}-\mathrm{Pb}$ dates provided on the figure underneath stratigraphic columns. Tripartite Sequence A, B, and C division modified from Young (1981) Sub-sequences sB1-5 after Long et al. (2008). Higher order sequences for Fifteenmile Group after Macdonald et al. (2012); Kilian and Kuujjuua formations after Rainbird (1993). The grey area represents stratigraphy that we consider correlative, with black dashed lines showing approximate correlations of cycles. 
formations and the upper three (S6, S7 and S8) with the Minto Inlet and Wynniatt formations on the basis of carbon isotope stratigraphy.

Sequence stratigraphy of the Kilian and Kuujjua formations was documented by Rainbird (1993), in which four transgressive-regressive (emergent-submergent) cycles were interpreted. The Kilian and Kuujjua formations display northeastward stratigraphic thinning, erosional beveling, and evidence for block faulting, consistent with pre-eruptive crustal doming and mantle-plume generated asthenospheric upwelling related to the emplacement of the Franklin LIP.

\subsection{Methodology}

Fieldwork was undertaken in the summers of 2010 and 2011 with stratigraphic analysis focused in two areas with well-exposed stratigraphic sections (Fig. 1). Twenty outcrop sections and two drill cores were measured totaling $23.3 \mathrm{~km}$ (see Appendix 1 for coordinates). Sedimentary descriptions described below incorporate previous work.

\subsection{Lithostratigraphy and sedimentology}

\subsubsection{Jago Bay Formation}

The Jago Bay Formation, the uppermost unit of the Reynolds Point Group, conformably overlies sandstones of the Fort Collinson Formation (Fig. 1), which is composed of cross-bedded quartz arenite and quartzose carbonate arenite interpreted to 
be of marine-reworked fluvial deposits (Rainbird et al., 1994). The contact between the Fort Collinson and Jago Bay formations is gradational within an upward deepening succession between fluvial to marginal-marine deposits (Fort Collinson Formation) and marine carbonate rocks (Jago Bay Formation), which in turn shallow upward into a gradational contact with the overlying evaporitic Minto Inlet Formation. The thickness of the Jago Bay Formation varies from $<65 \mathrm{~m}$ in the northeast Minto Inlier to $>200 \mathrm{~m}$ in the southwest Minto Inlier (Young et al., 1979), consistent with overall thickening of the upper Shaler Supergroup to the southwest (Thomson et al., 2014; Long et al., 2008). Rainbird et al. (1994) described it as an upward-shallowing succession of carbonate-rich sediments, from intertidal-lagoonal to supratidal and restricted intertidal. Where we observed the lower Jago Bay Formation in southwest Minto Inlier, it is composed of carbonaceous calcilutite with black shale interbeds and molartooth structure, supporting a lagoonal depositional environment (cf. James et al., 1998).

\subsubsection{Minto Inlet Formation}

The contact between the Jago Bay and Minto Inlet formations is not exposed, and is intruded by a diabase sill at the formational stratigraphic boundary in drill core, but appears to represent a gradational transition from supratidal and restricted intertidal carbonate rocks of the upper Jago Bay Formation (Rainbird et al., 1994) to supratidal maroon, gypsiferous carbonate mudstones that characterize the lower Minto Inlet 
Formation (Fig. 15). The Minto Inlet Formation ranges in thickness between $260 \mathrm{~m}$ and
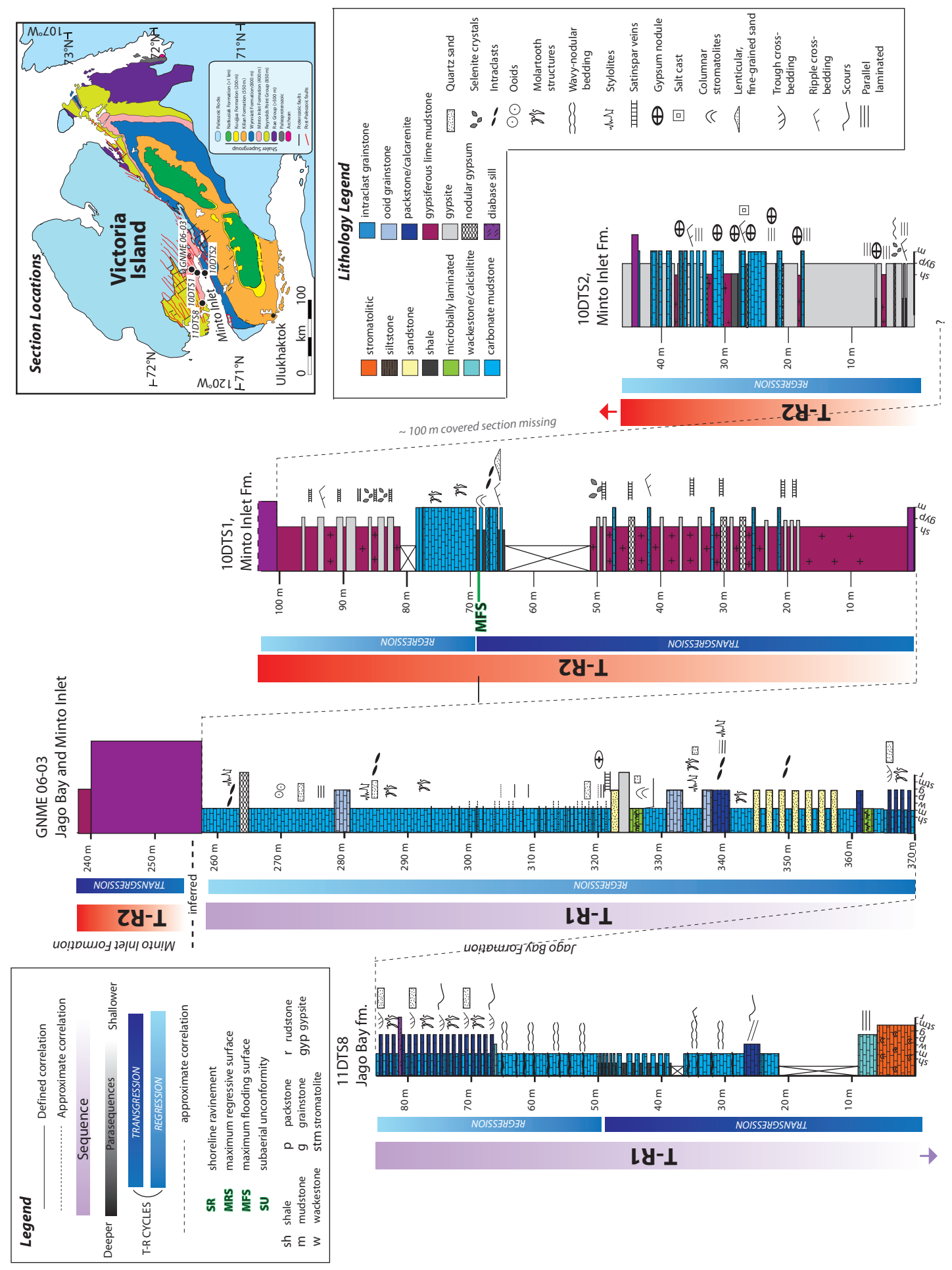

Figure 15. Measured stratigraphic sections of the Jago Bay and Minto Inlet formations. Interpretations of T$\mathrm{R}$ cycles are shown. Inset map shows locations of stratigraphic sections. 
$400 \mathrm{~m}$ (Rainbird et al., 1996), and comprises rhythmically alternating bedded gypsum, gypsiferous shale, and carbonate. An informally defined lower evaporitic unit comprises interbedded red gypsiferous and calcareous siltstones, and thinly bedded gypsum and anhydrite. Ripple cross-lamination, chickenwire texture, satinspar veinlets, selenite crystals, and nodular anhydrite are preserved, consistent with a supratidal mudflat environment (cf. Kendall, 2010). An overlying lower carbonate unit is characterized by stromatolites, hummocky cross-stratified (HCS) calcarenite, and molartooth structure in silty, carbonaceous lime mudstone. This lower carbonate unit is interpreted as a basinfreshening event with deposition occurring in a shallow subtidal environment. Bedded gypsum, chickenwire anhydrite, and satinspar veining characterize a middle evaporitic unit, and are interpreted as subaqueous evaporite deposition where gypsum was precipitated at the sediment-air interface producing cumulate gypsite deposits (Kendall, 2010). The upper evaporitic unit contains rhythmically alternating limestone, interbedded limestone- siltstone-gypsum, and nodular gypsum. This upper evaporitic unit is interpreted to record alternating basin freshening and restriction in a shallow subtidal to supratidal depositional environment.

\subsubsection{Wynniatt Formation}

The contact between the Minto Inlet and Wynniatt formations is not exposed in the Minto Inlier, but is interpreted to be gradational, based on facies stacking patterns. 
The thickness of the Wynniatt Formation in Minto Inlier varies from 1000 meters in the

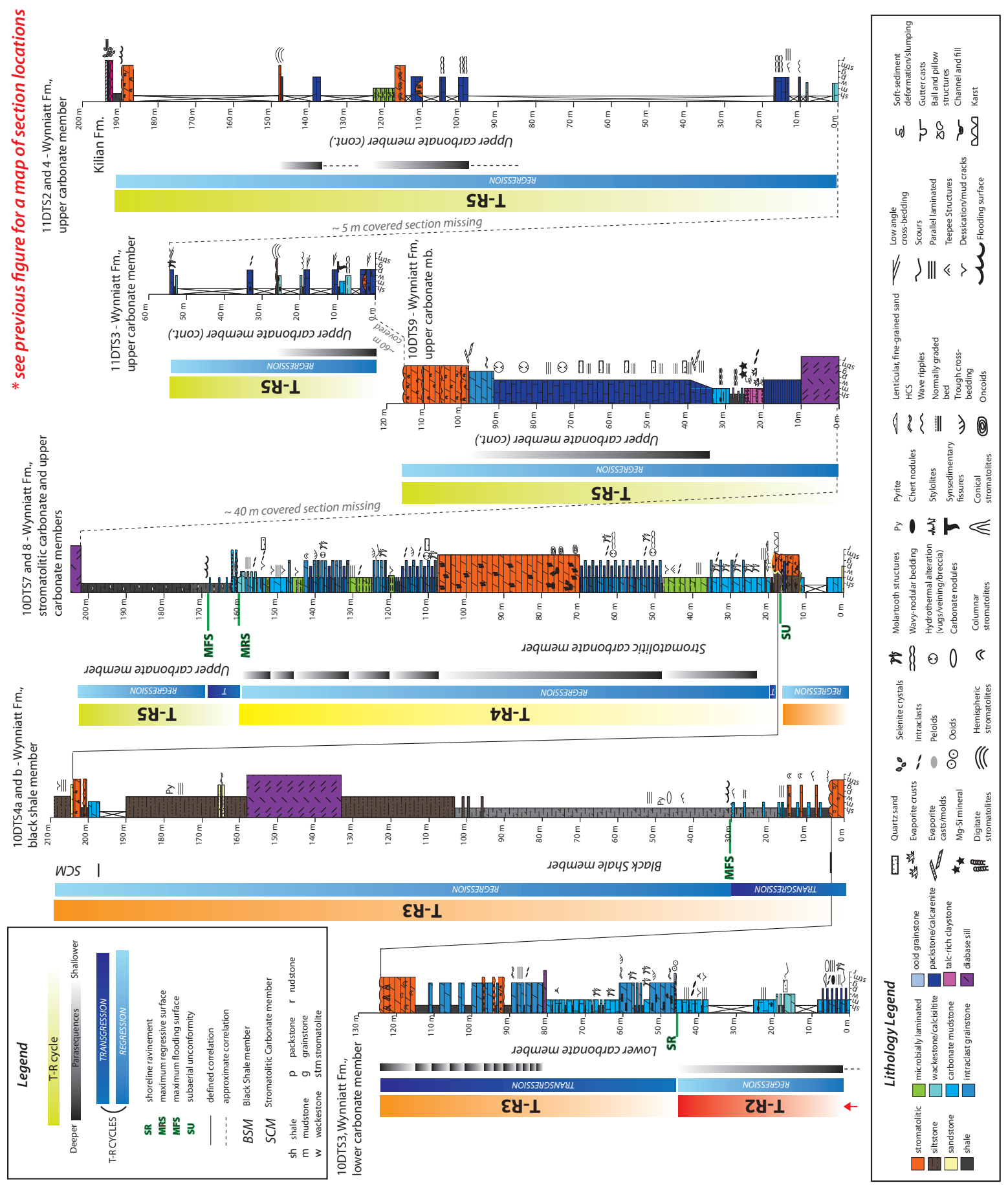

Figure 16. Measured stratigraphic sections of the Wynniatt Formation and members, with T-R cycles, parasequences, and important stratigraphic surfaces indicated. Refer to Figure 16 for a map of stratigraphic section locations. 
SW to 480 meters in the NE (Young, 1981; Rainbird et al., 2012; Thomson et al., 2014).

The Wynniatt Formation is divided into four informal members (Fig. 16), 1) Lower Carbonate member, an upward-deepening succession of supra- to sub-tidal carbonate rocks; 2) Black Shale member, a recessive interval of dark-grey siltstone and silty shale deposited in a pro-delta setting; 3) Stromatolitic Carbonate member, comprising stacked upward-shallowing cycles of subtidal to supratidal carbonate rocks and, 4) Upper Carbonate member, an upward-shallowing succession from subtidal black calcareous shale to peritidal cross-bedded intraclast grainstone and stromatolitic limestone. The Wynniatt Formation is interpreted to have been deposited along a distally steepened carbonate ramp, dominated by storm-generated depositional processes, with minor reworking by wave- and tidal currents (Thomson et al., 2014).

\subsection{T-R cycles}

A transgressive -regressive (T-R) cycle is defined as a complete cycle between one deepening event and the start of the next event of the same scale, whereby one T-R cycle may be composed of several smaller cycles or, in turn, may be a part of a largerscale cycle (Johnson et al., 1985). Best used to document and characterize basin-scale changes in stratigraphy (Embry, 1993), a T-R cycle is recognized by changes in facies stacking patterns that record upward-deepening and upward-shallowing successions, the change in which may be marked by a subaerial unconformity, regressive surface of marine erosion, shoreline ravinement surface, or flooding surface (cf. Embry, 2009). This method is a useful approach to understanding basin-fill patterns for a data set that is 
based on outcrop studies, in particular when rocks are poorly constrained in terms of geochronology, as is the case for the Amundsen Basin. Therefore, we follow stratigraphic models of Embry (1993; 2009), and interpret several T-R cycles that are nested within the previously defined sequence stratigraphic framework of Long et al. (2008) and Young et al. (1979), discussed above.

Intracontinental basins typically are shallow-water, long-lived depositories characterized by slow subsidence rates (e.g. Xie and Heller, 2009). Sedimentation rates generally are lower compared to other types of basins, and sequences can be traced laterally for long distances (Vecsei and Duringer, 2003). These shallow-marine sag basins present particular problems for documentation of cycles because base-level changes usually are subtle and their impact on facies tracts have wide lateral extent. Also, with poorly defined or very gentle slopes, changes are difficult to infer. Ramp, rather than shelf-slope geometries dominate, although some sag basins lack obvious seaward paleobathymetric changes. Documentation of accommodation cycles, and interpretation of their causes, is therefore a challenge. A sag basin generally exhibits such subtle stratigraphic changes that it is important to document and recognize the larger significance of what may be seemingly insignificant surfaces, within the context of internal facies stacking patterns.

\subsubsection{Sequence $s B 3$}

Sequence sB3 in the Amundsen Basin comprises the Boot Inlet, Fort Collinson, and Jago Bay formations (Long et al., 2008). Within sB3, we document one T-R cycle (T-R1), described below. 


\subsubsection{T-RI}

The transition from emergent, re-worked fluvial deposits of the Fort Collinson Formation, through submergent peritidal and lagoonal carbonate rocks of the Jago Bay Formation, and back to emergent supratidal mudflat deposits at the base of the Minto Inlet Formation represents a transgressive-regressive cycle that we define as T-R1 (Fig. 15). The contact between the Jago Bay and Minto Inlet formations (that is, the sB3-sB4 boundary), is not exposed, and in drill core is obscured by a diabase intrusion.

\subsubsection{Sequence $s B 4$}

As defined by Long et al. (2008), sequence sB4 is composed of the Minto Inlet and Wynniatt formations in the Amundsen Basin. Within sB4, we document four T-R cycles (T-R2 to T-R5), described below.

\subsubsection{T-R2}

T-R2 begins at the base of the Minto Inlet Formation, and extends upward through the base of the Lower Carbonate member of the Wynniatt Formation (Fig. 16). The contact between the Minto Inlet and Wynniatt formations is not exposed in the study area, but it appears to be gradational with facies variations recording an upwardshallowing trend. The lower Minto Inlet Formation comprises maroon, gypsiferous lime mudstones that we interpret as shallow-water, marginal-marine deposits. These pass upward into subtidal carbonate rocks that suggest deposition in deeper water, openmarine conditions (Fig. 15). The upper Minto Inlet Formation is composed of basincentral, sulphate crystal cumulate deposits (Kendall, 2010) that shallow upward into 
cyclically interbedded carbonate and evaporite rocks. The basal section of the overlying Lower Carbonate member of the Wynniatt Formation comprises shallow-water carbonate rocks with features that include mud-cracks, tepee structures, and halite pseudomorphs, thereby defining emergent conditions.

\subsubsection{T-R3}

The boundary between T-R2 and T-R 3 is an erosion surface about $45 \mathrm{~m}$ above the base of the Lower Carbonate member in the southwest Minto Inlier (Fig. 16). This surface can be traced $\sim 160 \mathrm{~km}$ across the Minto Inlier to a section measured in the northeast (Fig. 17), however the surface there is not as well developed. Below that surface, the uppermost carbonate rocks of T-R2 relate to base-level low during which large-parts of the platform must have been periodically exposed and eroded. Above the surface, carbonate floatstone comprising clasts of peloidal floatstone and dololutite in a grainstone matrix (Fig. 17), is interpreted to record subaerial erosion of the platform, and is defined as the basal unit of T-R3. Facies stacking above the floatstone unit is grossly upward-deepening (see below), such that the erosion surface fits the definition of a shoreline ravinement (cf. Embry, 2009), that is, an abrupt, scoured contact whose overlying sediments fine upward as a consequence of water deepening.

The remainder of the Lower Carbonate member, above the shoreline ravinement, and the Black Shale member together preserve an upward-deeping facies trend (Figs. 16 \& 17). Individual parasequences are upward deepening, commonly from columnar stromatolites to cross-bedded intraclast grainstones that are overlain by black shale. Collectively, parasequence stacking is also upward-deepening as the proportion of shale 
increases up-section. A maximum flooding surface (MFS) is interpreted to occur

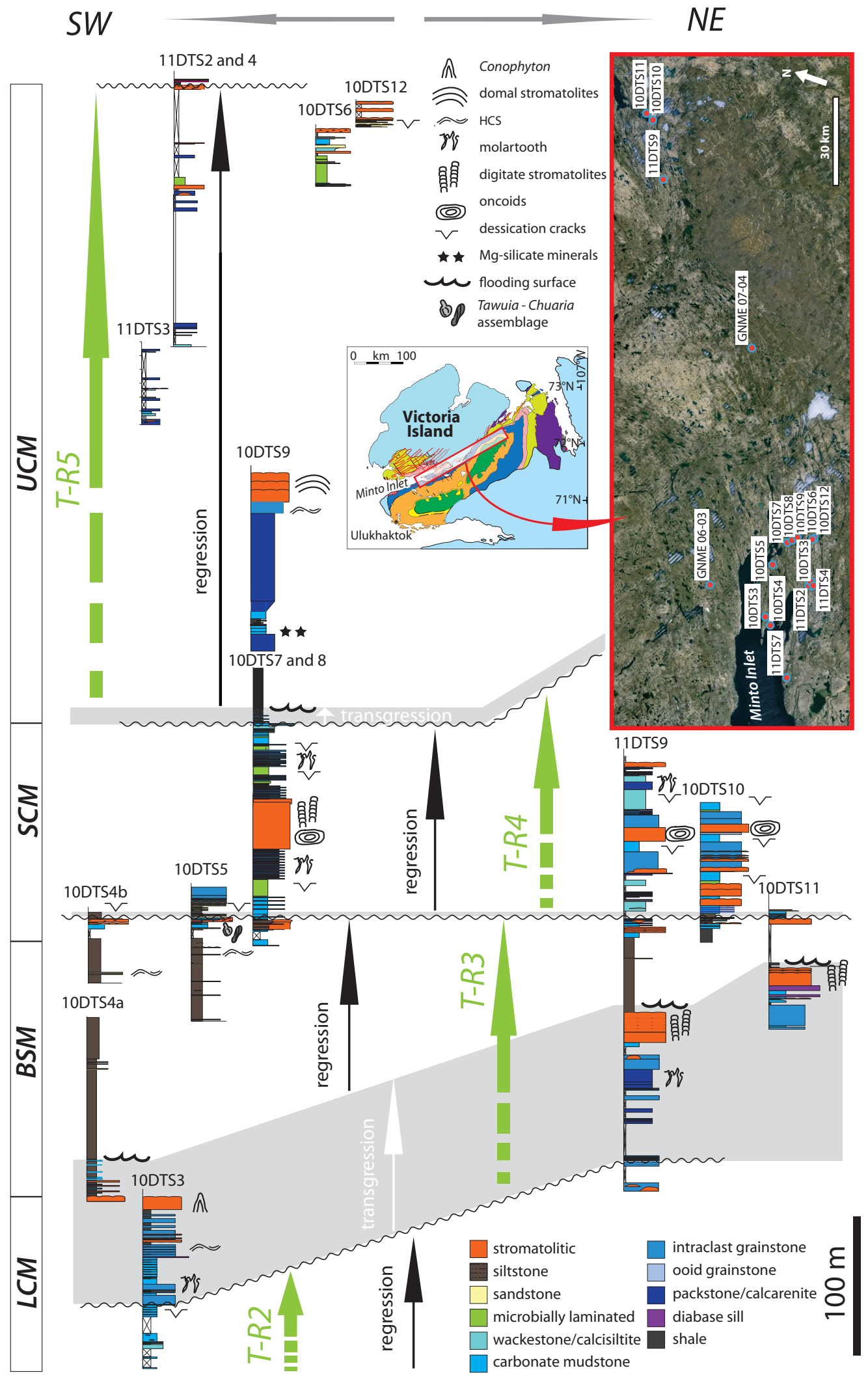


Figure 17. (previous page) Southwest to northeast cross-section of the Wynniatt Formation, showing regional T-R cycle correlations. LCM - Lower Carbonate member, BSM - Black Shale member, SCM Stromatolitic Carbonate member, UCM - Upper Carbonate member.

approximately twenty meters above the base of the Black Shale member, at the position where there is no longer any carbonate and the shale is extremely silt-poor (Fig. 16). The MFS therefore records complete submergence of the platform below fair-weather wave base (FWWB), as hemipelagic sedimentation overwhelmed carbonate production.

Above the MFS in the Black Shale member, sedimentation units coarsen upward and shallow from an interpreted distal pro-delta depositional environment to a peritidal flat and lagoonal depositional environment (Thomson et al., 2014). This upwardshallowing trend defines the onset of the regressive phase of T-R3, as sediment flux offset generation of new accommodation.

\subsubsection{T-R4}

The boundary between Sequences T-R3 and T-R4 occurs near the base of the Stromatolitic Carbonate member and is preserved across Minto Inlier, being recognized in all sections where this sequence is exposed (Fig. 17). It is a surface characterized by karstification features such as irregular pitting and undercutting of the underlying orangeweathered stromatolitic dolostone and dololutite (Fig. 18), thereby identifying it as a subaerially cut unconformity. Overlying the unconformity is a thin bed of quartz arenite that locally contains a lag of pebbles and cobbles derived from the underlying dolostone. The quartz arenite is overlain by less than a meter of dolomitic siltstone with desiccation cracks, consistent with a shallow-water marine environment and drowning of the karstic 
surface.
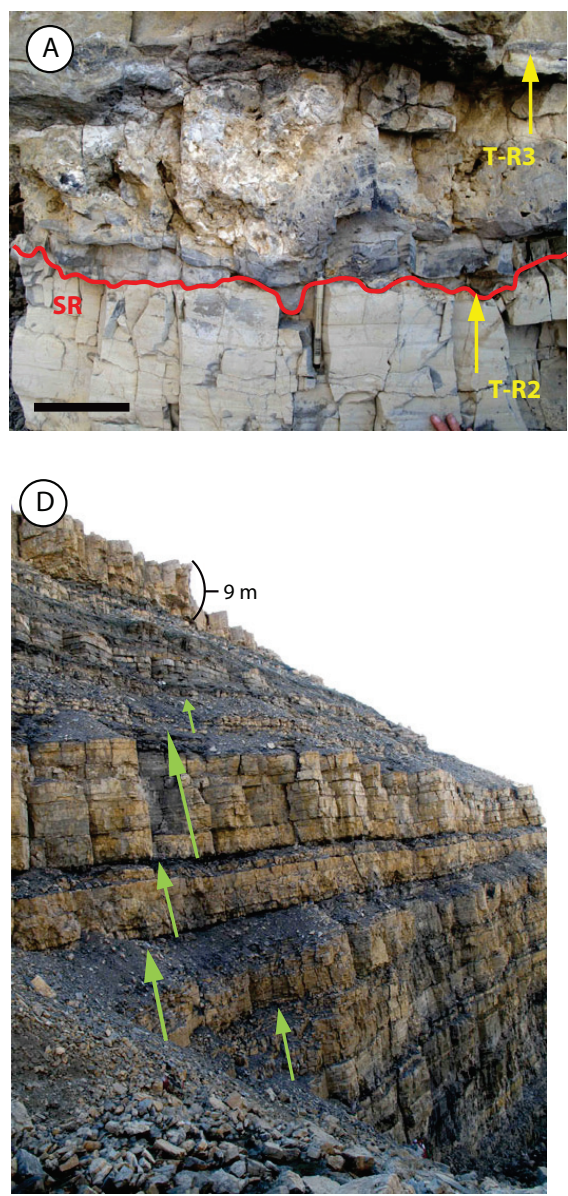

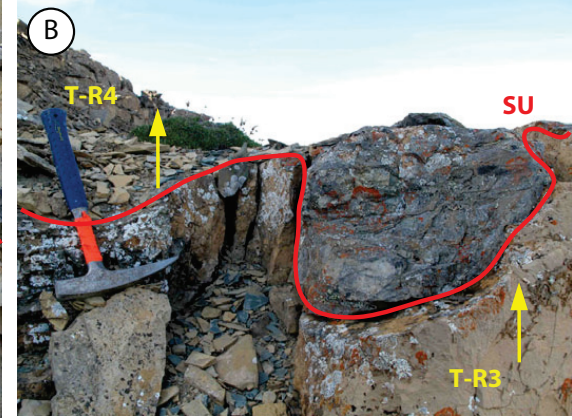

(E)

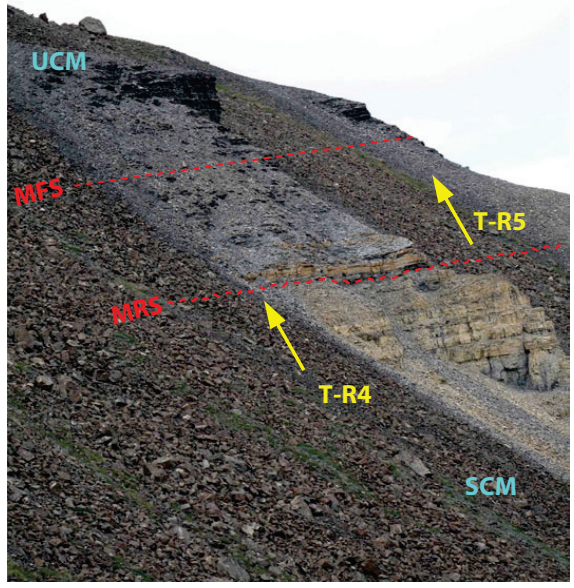

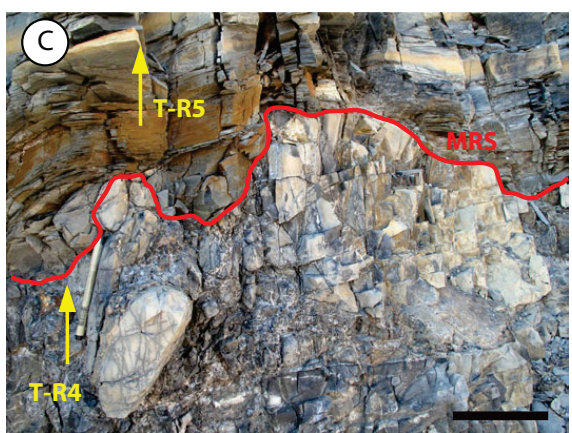

(F)

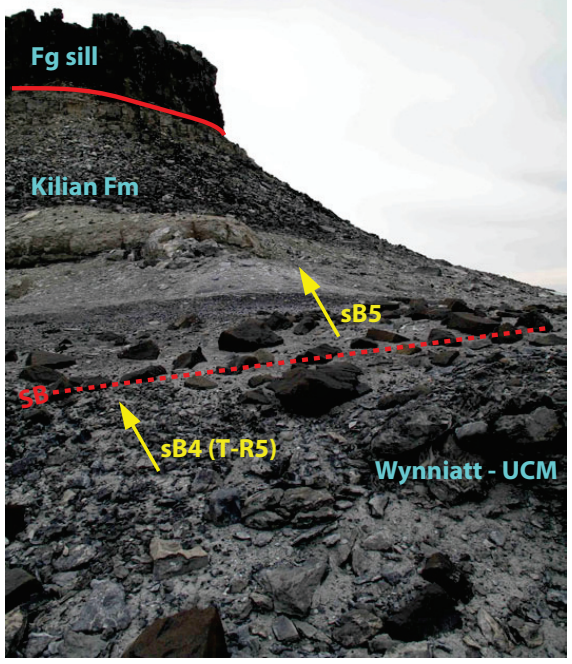

Figure 18. Photographs of sequence boundaries and T-R cycles in outcrop. (A) Shoreline ravinement (SR) and boundary surface between T-R2 and T-R3 in the Lower Carbonate member. (B) Subaerial unconformity (SU) and boundary between T-R3 and T-R4 in Stromatolitic Carbonate member. (C) Maximum surface of regression (MRS) and boundary between T-R4 and T-R5 at the contact between the Stromatolitic Carbonate member and Upper Carbonate member. (D) Cycles composed of sharp-based, orange weathering, thin-bedded dolostone grading upward into laminated black shale interpreted as upward-deepening parasequences (green arrows) near the top of Lower Carbonate member. (E) Maximum flooding surface (MFS) above the T-R4 and T-R5 contact. The boundary between the two is marked by a maximum surface of regression (MRS) that coincides with the Stromatolitic Carbonate member and Upper Carbonate member contact. (F) Excavated contact between the Wynniatt Formation and overlying Kilian Formation, which forms the sB4 - sB5 (cf. Long et al., 2008) boundary.

A set of upward-shallowing parasequences makes up the remainder of T-R4 (Fig. 16). Facies assemblages shallow upward from mid-ramp subtidal deposits, typically 
composed of interbedded molar-tooth mudstone and molar-tooth microspar packstone, to inner-ramp subtidal deposits, culminating at the top of the parasequence set with peritidal flat and lagoonal deposits, most commonly preserved as dolomitic siltstone with dessication cracks. The second parasequence identified in T-R4 (Fig. 16) is more than twice as thick ( $>50$ metres thick) as the other parasequences in T-R4, indicating that either there was a change in local subsidence rates or the identification of more parasequences is masked by the nature of the deeper depositional environment.

\subsubsection{T-R5}

There is a deeply scoured surface between the Stromatolitic Carbonate member and the overlying Upper Carbonate member. The surface separates, shallow-marine carbonate rocks at the top of an upward-shallowing parasequence set, from overlying, deep-water, black, nodular, calcareous shale at the base of an upward-deepening parasequence set. The Stromatolitic Carbonate member - Upper Carbonate member boundary is therefore interpreted to be a surface of maximum regression (MRS; Fig. 16). As a MRS marks the onset of transgression (Embry, 2009), the surface is also interpreted as the boundary between cycles T-R4 and T-R5.

The base of T-R5 is overlain by thin beds of limestone-pebble conglomerate that grade upward into calcareous shale, which in turn pass upward into black carbonaceous shale (Figs. 16-18). The package is interpreted to represent the transgression, overlying which a MFS marks the change from upward-deepening to upward-shallowing facies, indicating the subsequent regression. 
Above the MFS, a thick ( 160 m) upward-shallowing succession begins with carbonaceous, calcareous shale that pass upward into thinly bedded calcarenite turbidites. The depositional site is interpreted to have been outer-ramp. Above this succession is a parasequence set that alternates between inner-ramp deposits of interbedded cross-bedded intraclast grainstones, columnar stromatolites, and laminated dolomudstones (Fig. 16).

Stromatolitic carbonate rocks at the top of the Upper Carbonate member are sharply overlain by $\sim 3 \mathrm{~m}$ of carbonaceous shale that grade into nodular gypsum; these evaporite rocks mark the base of the Kilian Formation (Fig. 17). A hiatal surface is interpreted on the top of Upper Carbonate member, above the carbonate rocks and at the base of the shale, corresponding to a switch from open-marine carbonate rocks to a restricted, sabkha environment. An unconformity separates the Upper Carbonate member from the overlying Kilian Formation (Figs. 16 \& 17), but outcrops are not laterally extensive, and there is no obvious evidence for subaerial exposure or stratal discordance. A hiatus across this boundary is interpreted to account for the abrupt change from openmarine carbonate rocks to sabkha evaporite rocks. Other changes that coincide with this interval include variations in sulfur and carbonate isotopes (Jones et al., 2010; Prince, 2014, Thomson et al., in review), and a switch to a subsidence regime interpreted to have been influenced by thermal doming in the overlying middle Kilian Formation (Rainbird, 1993). Long et al. (2008) placed the sB4-sB5 sequence boundary at the boundary between the Wynniatt and Kilian formations and that interpretation is followed here.

\subsection{Correlation with adjacent basins}


Neither sequence nor T-R stratigraphy has been documented for the Little Dal Group in the Mackenzie Mountain Supergroup. Sequences defined for the Fifteenmile Group of the Ogilvie Mountains are difficult to correlate with the upper Shaler Supergroup because deposition of the the Fifteenmile Group was strongly influenced by local tectonism (Macdonald et al., 2012). Nevertheless, sequences within the Fifteenmile Group have been correlated across NW Laurentia using carbon isotope stratigraphy (Macdonald et al., 2012). Sequence S6 of the Fifteenmile Group in the Ogilvie Mountains is interpreted to be significantly condensed compared to sequences in the Shaler and Mackenzie Mountains supergroups. S6 is correlated with the combined Minto Inlet Formation and Lower Carbonate member, Black Shale member and Stromatolitic Carbonate member of the Wynniatt Formation in Minto Inlier, and the Ten Stone, Snail Spring, and base of the Ram Head formations in the Mackenzie Mountains Supergroup (Macdonald et al., 2012; Turner and Long 2012; Fig. 14). S6 currently is interpreted to record a steady increase in $\delta^{13} \mathrm{C}$ (VPDB) from $+2 \%$ to $+10 \%$ in the lower half of the sequence in the Fifteenmile Group, whereas in the Mackenzie Mountains the opposite trend is preserved, with a steady decline from $+6 \%$ to $0 \%$ for the lower half of the interpreted correlative sequence (Halverson, 2006; Macdonald et al., 2012). In the Shaler Supergroup, $\mathrm{C}$ isotopes show a steady decline from $\sim 4 \%$ to $-1 \%$ over the same correlated interval (Jones et al., 2010; Macdonald et al., 2012; Thomson et al., in review). We suggest that the chemostratigraphic correlations are tenuous, and that correlation of sequences from the Fifteenmile Group need to be re-evaluated because of poor chemostratigraphic correlation. 
Sequence S7 in the Fifteenmile Basin (Macdonald et al., 2012) correlates well with T-R5 in the Amundsen Basin and the Ramhead Formation in the Mackenzie Basin, and preserves a negative carbon isotope excursion in all three basins (Jones et al., 2010; Halverson et al., 2012; Macdonald et al., 2012, Thomson et al., in review). This sequence represents a basin-deepening event that is present across NW Laurentia, so sea-level rise was likely eustatic; although attendant tectonically driven subsidence in each basin probably exaggerated the sediment thickness, particularly in the Reefal assemblage of the Fifteenmile Group. This is an important correlation because the base of this sequence has been dated at $811.5 \mathrm{Ma}$ from a tuff bed in the Reefal assemblage (U-Pb zircon; Macdonald et al., 2010), and because it contains a pronounced negative carbon isotope excursion that can be correlated with the global Bitter Springs Stage (Jones et al., 2010; Macdonald et al., 2012).

Sedimentation rates for the Fifteenmile Group are interpreted to have been high due to rapid generation of accommodation by extensional faulting that also was responsible for abrupt thickness and facies changes (Macdonald et al., 2012). Gravitydriven slope deposits, such as olistoliths and talus breccias, as well as prograding stromatolite reef complexes, dominate lithofacies of the Reefal assemblage and Craggy dolostone (Macdonald et al., 2012). Extension-controlled accommodation appears to have been rapidly infilled within the Fifteenmile basin. This contrasts with the slow sedimentation rates inferred for the Shaler Supergroup, where deposition occurred on a slowly subsiding carbonate ramp dominated by shallow-marine facies, such as mudcracked dololutite, molar-tooth mudstone, and biostromal stromatolites that produced a layer-cake stratigraphy (Thomson et al., 2014). We therefore expect that the stratigraphy 
of the Shaler Supergroup should be condensed relative to the Fifteenmile Group, rather than the opposite, as was suggested by Macdonald et al. (2012). Unless there is a significant hiatus, which may be recorded in a mudcracked, weakly karstic, subaerial exposure surface reported from the top of the Gibben Formation (Halverson et al., 2012; Macdonald et al., 2012), it appears unlikely that the base of the Fifteenmile Group could be much older than $\sim 900 \mathrm{Ma}$, given the $811.5 \mathrm{Ma}$ age from an ash layer in the upper the Reefal Assemblage (Macdonald et al., 2010). The Boot Inlet Formation of the Shaler Supergroup has a Re-Os depositional age of $892 \pm 13$ Ma from drill-core samples of black shale (van Acken et al., 2013), and there is an additional $1.5 \mathrm{~km}$ of strata preserved below it. We propose that the Fifteenmile Group does not correlate with the lower Mackenzie Mountains or Shaler supergroups (Fig. 14), but instead only with the upper Mackenzie Mountains Supergroup (Little Dal Group) and the upper Shaler Supergroup (Boot Inlet to Kilian formations).

\subsection{Cause of cyclicity}

Despite the Amundsen Basin being an intracontinental sag basin prior to deposition of the Kilian and Kuujjua formations (Rainbird, 1993), subsidence does not appear to have been gradual; rather it was rhythmic and generally outpaced sediment flux. Cyclic deposition during this time period was not all symmetrical or harmonious (Figs. 15 and 16), and difficult to correlate with other basins (Fig. 14). The overall depositional trend of the studied stratigraphic interval is transgressive, although there are sections within which parasequence stacking is consistent with regression. 
Most cyclicity in the rock record is attributed to eustasy caused by climate change, oceanic ridge pulses, rhythmic basin subsidence, and the expanse or retreat of glaciers (i.e. glacioeustasy). Although the late Neoproterozoic is noted for global scale, low latitude glaciations, the studied formations were deposited between 850 and $750 \mathrm{Ma}$ (van Acken et al., 2013), before the first mid-Cryogenian glaciation (Kendall et al., 2006;

Smith, 2009). Therefore, glacioeustacy likely was not the driver for the documented cyclicity, however there may not be a record of contemporaneous glaciation. Other possible drivers for sea-level change are difficult to attribute specifically to the cyclicity documented from the Amundsen Basin. Greater understanding of causal factors may come from correlation with coeval sequences worldwide, for example with the Amadeus Basin of central Australia (Rainbird et al., 2012), however given the current lack of geochronological constraints, assigning causality to global cyclicity is difficult.

\subsection{Basin duration, subsidence patterns and tectonostratigraphy}

Lacking biostratigraphic controls and dated tuff beds, constraints from detrital zircon geochronology indicate the maximum duration for deposition of the Shaler Supergroup was approximately 400 million years (Rayner and Rainbird, 2013; Fig. 1), equivalent in Phanerozoic time from the base of the Devonian to the present day, although sedimentation was likely not continuous. This is not an unreasonable estimate if it is accepted that the upper half of the succession was deposited in approximately 180 million years (van Acken et al., 2013). Nevertheless, the Amundsen Basin appears to have been long-lived and its fill relatively thick $(\sim 4 \mathrm{~km})$ for an intracontinental basin (cf. 
Allen and Armitage, 2012). The duration of deposition of the Wynniatt Formation is also poorly constrained, but is estimated to have been 50-100 million years, and is up to $1 \mathrm{~km}$ at its thickest, in the southwest Minto Inlier. There are other examples of long-lived Paleozoic intracontinental basins, for example, the Williston Basin in Saskatchewan ( 400 m.y.; Xie and Heller, 2009), the Northeast German Basin ( 300 m.y.; Xie and Heller, 2009), and the Hudson Bay Basin (Upper Ordovician to present; Pinet et al., 2013).

Long et al. (2008) determined that there are at least five, unconformity-bound, supersequences (i.e. Sloss-style second-order cycles) in the Shaler Supergroup, implying that there were lengthy hiatuses between sequences, and that unconformities may separate discrete sub-basins or tectonic stages (cf. Krapez, 1997). Sequence sB4 (Long et al., 2008), and its component T-R cycles (T-R2 to T-R5), likely were deposited in one of these discrete, unconformity-bounded basins, separated from the underlying succession by a karstic unconformity at the top of the Boot Inlet Formation (Narbonne et al., 2000). This would imply that the surface separates different tectonic stages of the Amundsen Basin (Fig. 19), although it does not imply those tectonic stages were unique to the Amundsen Basin. Separate tectonic stages were described for the Ogilvie and Mackenzie basins (Turner and Long, 2008; Macdonald et al., 2012), but it was not established whether they were of the same rank as the unconformity-bounded sequences recognized in the Amundsen Basin. The episodic pattern of basin subsidence described is consistent with Paleozoic intracontinental basins such as the Michigan Basin, where four subsidence episodes (or tectonic stages) were identified using stratigraphic geometry, backstripping of subsidence rate, and depositional facies architecture (Howell and van der Pluijm, 
1990). This suggests there is nothing novel about dividing the Amundsen Basin into unconformity-bound sequences that each relate to a different tectonic stage. The implication is that the stratigraphic succession of the Amundsen Basin is the product of stacked tectonic stages, each with a possibly different tectonic driver and subsidence regime.

We identify three different tectonostratigraphic units for the upper Shaler Supergroup, Stages 1-3 (Fig. 19). Stage 1 comprises T-R cycles 1 to 5 (of sB3 and sB4), which document a sag phase of basin development. This stage probably also includes underlying strata not discussed in this paper. Stage 2 comprises sequence sB5 (Long et al., 2008), which is made up of T-R cycles 1 to 4 of Rainbird (1993), and documents a period of active extension in the Amundsen Basin that is expressed through synsedimentary faulting interpreted to have been caused by plume-related thermal doming (Rainbird et al., 1993). Stage 3 comprises the Kuujjua (fluvial sandstone; Rainbird, 1992) and Natkusiak (flood basalts) formations that record the rifting stage of the Amundsen Basin.

The lack of extensional faulting, lateral continuity of strata, and predominance of shallow-water facies in the Amundsen Basin, supports sagging as the subsidence mechanism during Stage 1 (Figs. 14 and 19). The question is: what did that subsidence relate to? If it related to thermal decay, then it presumes there was a prior period of lithospheric stretching or asthenospheric doming. This sag phase of basin formation in the Amundsen Basin precludes the more active extensional phase of subsidence that accommodated the overlying Kilian, Kuujua, and Natkusiak formations (Stages 2 and 3) 
in rift-controlled basins. The subsequent thermal decay and flexural subsidence phases

Fm. Lithostratigraphy

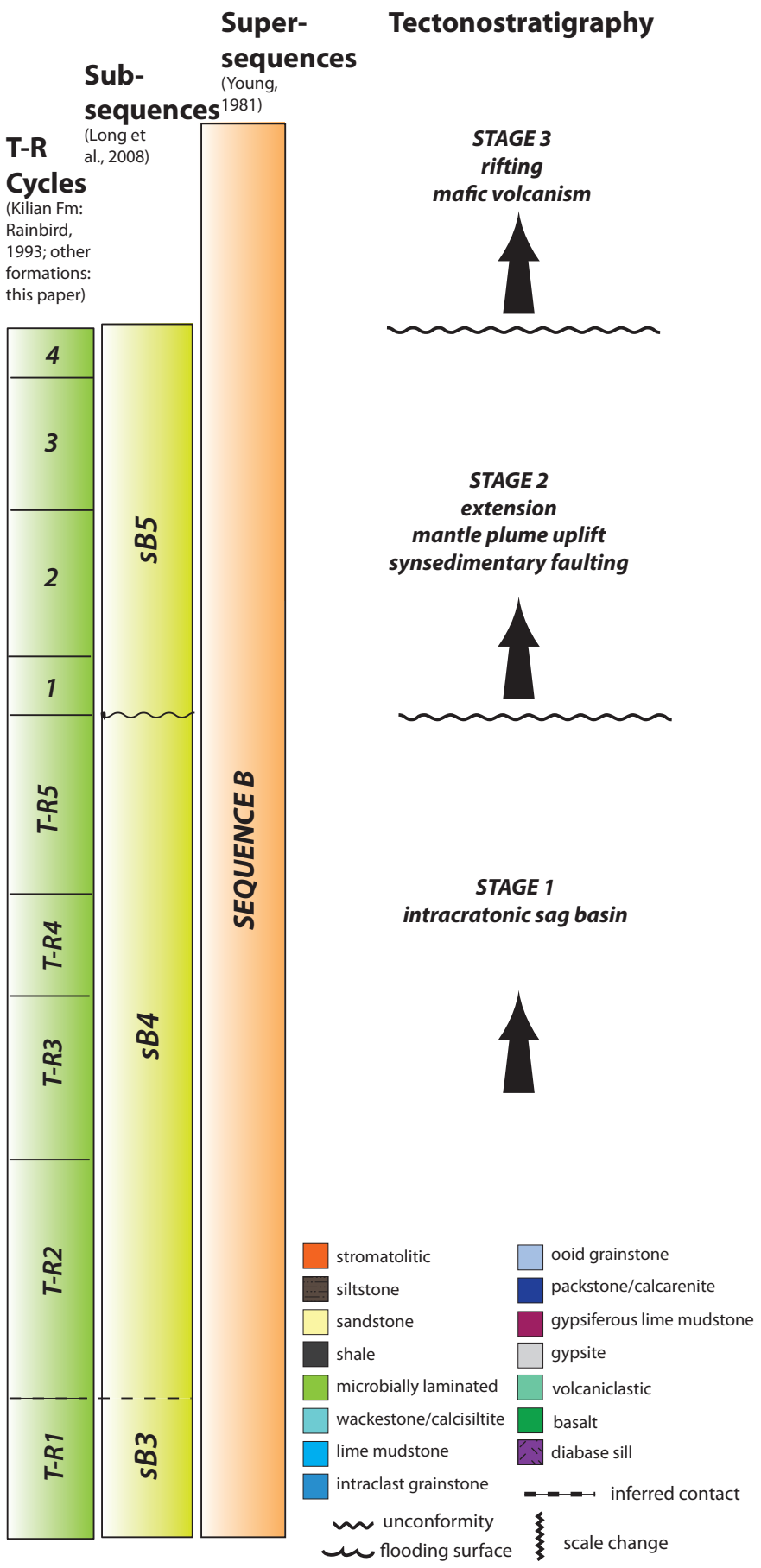

Figure 19. Composite lithostratigraphy, T-R stratigraphy, sequence stratigraphy, and tectonostratigraphy of the Jago Bay, Minto Inlet, Wynniatt, Kilian, Kuujjua, and Natkusiak formations. Lithostratigraphy and T-R stratigraphy of the Kilian Formation after Rainbird (1993). Supersequence boundaries after Young et al. (1981) and sub-sequence boundaries after Long et al. (2008). MDA - maximum depositional age. 
(i.e. drift phase), after ocean opening, is not preserved or exposed in Minto Inlier, but is preserved in the Windermere Supergroup in the Mackenzie Mountains (e.g. Ross, 1991). Therefore, the combined Jago Bay, Minto Inlet and Wynniatt formations (Stage 1, T-R1 to T-R5) relate to subsidence that preceded the breakup of Rodinia along the northnorthwest margin of Laurentia.

Macdonald et al. (2012) attributed post-830 Ma subsidence throughout NW Laurentia to extension and subsequent thermal decay associated with Rodinia passing over a mantle plume. That passage seemingly culminated at the emplacement of the 780 Ma Gunbarrel dykes and Tsezotene Sills (Harlan et al., 2003). This interpretation is based on the assumption that the conjugate margin to NW Laurentia was South China (Li et al., 1995). There was therefore a global-tectonic, mechanistic link between basin initiation in China, Australia, and Laurentia at $\sim 830 \mathrm{Ma}$, and emplacement of the Gairdner and Guibei LIPs between $~ 830$ and 810 Ma (Wingate et al., 1998; Li et al., 1999; Macdonald et al., 2012). The tectonic event correlates stratigraphically to the basin-forming event that accommodated the Reefal assemblage and Craggy dolostone (Fifteenmile Group), Little Dal Group (Mackenzie Mountains Supergroup), and possibly the Fort Collinson, Jago Bay, Minto Inlet, and Wynniatt formations (Shaler Supergroup). The maximum depositional age of the Fort Collinson Formation is $891 \pm 22 \mathrm{Ma}$ (Rayner and Rainbird, 2013) and is interpreted as high-energy, marine-reworked fluvial sandstone (Young and Long, 1977; Rainbird et al., 1996). This sandstone may record the initial transgression of this isolated basin event in the Amundsen Basin, supporting the timing of the subsidence model of Macdonald et al. (2012). The Gayna Formation of the Little Dal Group 
(Mackenzie Mountains Supergroup) is considered stratigraphically correlative with the Fort Collinson Formation, and is composed of high-energy, cross-bedded oolitic dolograinstone (Turner and Long, 2012), and therefore also represents a transgressive unit overlying the Silverberry/Stoneknife formations. It is important to note however, that there is no magmatic evidence for an $\sim 830$ Ma plume event in Laurentia, and that the 830 Ma event preceded the Franklin LIP by $>100$ million years, and the Gunbarrel LIP by 50 million years (Harlan et al., 2003). In fact, there is no evidence of an 830 Ma igneous event in Laurentia.

The tectonostratigraphic model of Macdonald et al. (2012) is nullified if the conjugate margin to northwest Laurentia was not South China. Regardless of the tectonic figuration, the most feasible interpretation of subsidence in the Amundsen Basin between $\sim 900$ to $780 \mathrm{Ma}$ is multiple cycles of intra-plate extension that complemented coeval fault-controlled subsidence, sedimentation and volcanism of the same age in the Mackenzie and Ogilvie basins.

\subsection{Inferences for the break-up of Rodinia along the northwest margin of Laurentia}

Rift basins are by definition associated with extensional faulting, and have stratigraphic architectures pinned to rift-margin faults and fault-bound compartments. Although intracontinental basins lack obvious basin compartments and extensional faults, they typically lie inboard of rifted continental margins and have the same timing, but the causal mechanism for their subsidence has been much debated (e.g. Allen and Armitage, 
2012). The Neoproterozoic successions of NW Laurentia present a similar spatial and temporal relationship between rift basins and intracontinental basins.

Sequence B strata that accumulated in NW-facing rift-basin margins are well documented from the Mackenzie Mountain Supergroup and Fifteenmile Group strata in the northern Cordillera (Figs. $1 \&$ 14; Turner and Long, 2008; Macdonald et al., 2012). In contrast, coeval strata in the Shaler Supergroup were not associated with basin-margin faults or intrabasinal fault-bound compartments. Therefore, while faulting and extension were active in the Mackenzie and Ogilvie Mountains, the Amundsen Basin was subject to a passive subsidence regime up to and including deposition of the Wynniatt Formation (Stage 1, Fig. 19). There is evidence for thermal doming and extensional faulting during deposition of the overlying Kilian and Kuujjua formations ( 780-720 Ma). Rainbird (1993) reported stratigraphic thinning, erosional beveling, and block faulting in those formations, and interpreted that this was consistent with crustal doming that accompanied mantle plume upwelling before the emplacement of the $\sim 720$ Ma Franklin LIP (Stage 2, Fig. 19). Despite the contrasts in stratigraphic architecture, these are coeval responses to regional-scale tectonic events, implying that subsidence drivers for the Amundsen Basin were somehow linked to those of the coeval rift basins in the northern Cordillera (Fig. $14)$.

That deposition of Sequence B strata south and west of Minto Inlier was already, at least in part, controlled by rift-related extensional faulting, has implications for correlation of higher-order basin events across northwestern Canada. Only deposition that responded to global (e.g. eustatic) controls may be registered in each basin, hence, the correlation of T-R5 in the Amundsen Basin with S7 in the Fifteenmile Basin (Macdonald 
et al., 2012). In post-Wynniatt strata (Stages 2 and 3), rift signals extended along the entire northwest margin of Laurentia, supporting multi-stage, diachronous, noncorrelative break-up of Rodinia.

\subsection{Conclusions}

- The Jago Bay Formation is part of Sequence sB3 and Minto Inlet and Wynniatt formations fit with Sequence sB4 of Long et al. (2008), and comprise one T-R cycle. Sequence sB4 has been further subdivided into four T-R cycles. T-R2 is composed of the Minto Inlet Formation and the basal part of the Lower Carbonate member, Wynniatt Formation. T-R3 comprises the remainder of the Lower Carbonate member, Black Shale member, and basal part of the Stromatolitic Carbonate member of the Wynniatt Formation. The boundary between T-R3 and $\mathrm{T}-\mathrm{R} 4$ is a subaerial unconformity representing a hiatus of unknown duration. TR4 comprises the remainder of the Stromatolitic Carbonate member, and the boundary between it and T-R5 lies at the base of the Upper Carbonate member of the Wynniatt Formation. T-R5 comprises the Upper Carbonate member, and its upper boundary corresponds to the formational boundary with the Kilian Formation, as well as the base of sequence sB5 (Long et al., 2008).

- T-R cycles are difficult to correlate regionally between basins because accommodation was greatly controlled by local tectonic factors (e.g. in the Fifteenmile basin). The exception appears to be sequence S7 from the Fifteenmile Group (Macdonald et al., 2012) and the coeval T-R5 defined here, which reflect a 
significant regional-scale deepening event that may relate to the onset of a globalscale marine transgression.

- We propose that the Fifteenmile Group is only correlative to the upper Shaler Supergroup (Boot Inlet to Kilian formations) and Little Dal Group (Mackenzie Mountains Supergroup).

- We recognize three tectonostratigraphic units in the upper Shaler Supergroup. Stage 1 records subsidence of a sag basin, Stage 2 preserves evidence of syndepositional faulting and thermal doming, and Stage 3 represents the rifting phase with the extrusion of continental flood basalts.

- Subsidence during deposition of the middle to upper Shaler Supergroup in the Amundsen Basin may be related to lithospheric stretching and thinning if northwest Laurentia had passed over a mantle plume at $830 \mathrm{Ma}$ as suggested by Macdonald et al., (2012), or may be related to intra-plate stresses related to some other cause of extension forming fault-bound rift basins in the Mackenzie Mountains and Fifteenmile basins.

- Analysis of pre-rift strata in the Amundsen Basin supports multi-phase, noncorrelative break-up of Rodinia along the northwest margin of Laurentia. 


\section{CHAPTER 4: CHEMOSTRATIGRAPHY AND GEOCHEMISTRY}

Thomson, D., Rainbird, R. H., Planavsky, N., Lyons, T., and Bekker, A.

Chemostratigraphy of the Shaler Supergroup, Victoria Island, NW Canada: a record of ocean composition prior to the Cryogenian glaciations. Submitted to Precambrian Research.

\subsection{Introduction}

The Neoproterozoic Era records dramatic changes in seawater chemistry that eventually led to emergence of Phanerozoic surface conditions. Various isotopic systems have been employed to interpret secular changes in Neoproterozoic ocean chemistry, most commonly carbonate and organic carbon isotopes (e.g. Halverson et al., 2005; Halverson et al., 2010; Swanson-Hysell et al., 2010; Walter et al., 2000), strontium isotopes (e.g. Halverson et al., 2007b; Thomas et al., 2004; Veizer, 1989), and sulphur isotopes (e.g. Kaufman et al., 2007; Loyd et al., 2012). Much of the work has focused on the period of the late Neoproterozoic glaciations and the Ediacaran - Cambrian transition, although attention is now being drawn to older successions and a broader array of redox proxies (e.g. Canfield et al., 2008; Johnston et al., 2010; Sperling et al., 2013).

In contrast to the Phanerozoic, the Neoproterozoic is characterized by intervals with sustained positive $\delta^{13} \mathrm{C}_{\text {carb }}$ values punctuated by abrupt shifts to negative $\delta^{13} \mathrm{C}_{\text {carb }}$ values (e.g. Halverson et al., 2010). The majority of the large, negative perturbations to the Neoproterozoic carbon cycle are associated with glaciations, but there are exceptions. One of them, the Bitter Springs stage, is defined by a negative excursion in the global carbon isotope record reported from many localities, including Australia (Walter et al., 
2000), Zambia (Bull et al., 2011), Svalbard (Halverson et al., 2007a), Scotland (Prave et al., 2009), and northern Canada (e.g. Jones et al., 2010; Macdonald et al., 2010). A U-Pb age from an interbedded tuff preserved below the base of the Bitter Springs stage in the Ogilvie Mountains, Canada, yielded an age of $811.5+/-0.25 \mathrm{Ma}$ (Macdonald et al., 2010). Although the Bitter Springs stage is not associated with a glaciation, it is interpreted to represent an interval of global change in the carbon cycle.

It is commonly assumed that the deep ocean became permanently oxygenated in the terminal Neoproterozoic and that this global redox shift was a driving force behind the diversification of multicellular life (e.g. Canfield and Teske, 1996; Des Marais et al., 1992). Many studies have sought to characterize the redox state of the deep ocean and specifically pinpoint when the oceans became fully oxygenated (e.g. Sahoo et al., 2012; Scott et al., 2008; Sperling et al., 2013). However, despite a surge of work over the past decade, there is still debate about Neoproterozoic marine redox evolution. Several independent studies suggest ocean oxygenation around $580 \mathrm{Ma}$ (Canfield et al., 2007; Fike et al., 2006; McFadden et al., 2008). More recent work suggests at least temporary pervasive ocean oxygenation earlier in the Ediacaran (ca. 635-630 Ma), in the immediate aftermath of the Marinoan 'Snowball Earth' glaciation (Sahoo et al., 2012).

Sedimentary rocks of the Shaler Supergroup were deposited in the Amundsen Basin and are exposed in the Minto Inlier, Victoria Island, Northwest Territories, Canada (Fig. 1). The upper Shaler Supergroup was deposited between $\sim 900$ and $720 \mathrm{Ma}$ and is exceptionally well preserved, providing an ideal target for marine paleoredox studies of the time interval leading up to the Sturtian glaciation. Further, this succession provides an opportunity to further explore $\delta^{13} \mathrm{C}_{\text {carb }}$ and $\delta^{13} \mathrm{C}_{\text {org }}$ trends through this important period of 
time. Herein, we present new $\mathrm{C}$ isotope, Fe-speciation, trace metal, and pyrite sulphur isotope data to interpret marine redox conditions and carbon cycle dynamics, including their global implications.

\subsection{Geologic Setting}

The Tonian (1000 - $850 \mathrm{Ma})$ to Cryogenian (850 - $635 \mathrm{Ma})$ Shaler Supergroup $(\sim 1100-723 \mathrm{Ma})$ is a $>4-\mathrm{km}$-thick sedimentary succession composed of predominantly shallow-marine carbonate rocks interstratified with mudstones, sandstones, and sulphate evaporites (Fig. 1) deposited in the Amundsen Basin, a shallow embayment within a larger epeiric sea that developed after the assembly of Rodinia (Rainbird et al., 1996; Rainbird et al., 1998; Young, 1981). The maximum age of the Shaler Supergroup is constrained by detrital zircon geochronology at $<1151 \mathrm{Ma}$ (Rayner and Rainbird, 2013). The minimum age is $723+4 /-2$ Ma based on $\mathrm{U}-\mathrm{Pb}$ geochronology of diabase sills that intrude the sedimentary succession and feed overlying flood basalts, part of the Franklin Large Igneous Province (Heaman et al., 1992). Three depositional ages of $892 \pm 13 \mathrm{Ma}$ (Boot Inlet Formation), $849 \pm 48 \mathrm{Ma}$ (Black Shale member of the Wynniatt Formation), and $761 \pm 41 \mathrm{Ma}$ (Upper Carbonate member of the Wynniatt Formation) based on Re-Os black shale geochronology provide additional chronostratigraphic constraints (Fig. 1, van Acken et al., 2013). The strata are relatively undeformed, with dips typically less than 10 degrees, and have experienced only low-grade contact metamorphism by the diabase sills (Fig. 3). 

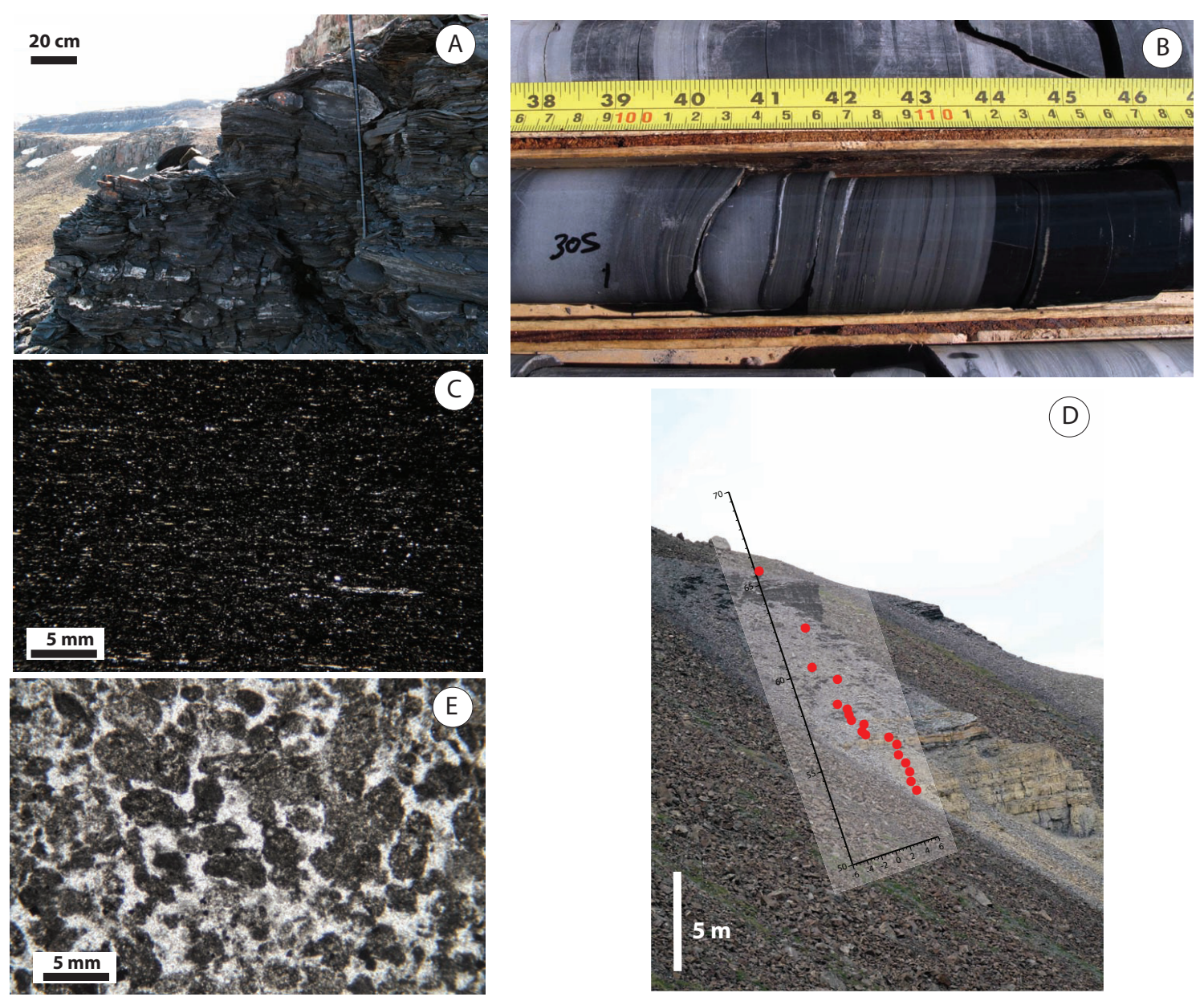

Figure 20. Photos of rocks that record the negative carbon isotope excursion in the Upper Carbonate member. A) Outcrop photo of black shale and limestone nodules enveloped by shales showing differential compaction. B) Photo from drill core GNME 07-04. Meter 305 is marked on the core, stratigraphic up is to the right. C) Thin section photo of carbonaceous, calcareous black shale, plane polarized light (PPL). D) Measured section with $\delta^{13} \mathrm{C}_{\text {carb }}$ values overlain. Note that the values suddenly drop over the sharp boundary of the limestone to shale. E) Thin section photo of a calcarenite (turbidite). The bright white is the calcite cement that has infilled pore space surrounding the carbonate sand allochems. PPL.

The Boot Inlet Formation is characterized by large stromatolitic bioherms that formed along a carbonate ramp, with interstratified inner and mid-ramp deposits (Narbonne et al., 2000). An upward-shallowing trend is preserved in the overlying Fort Collinson Formation, an interval of fluvial and marine-reworked sandstones (Rainbird et al., 1994). The overlying Jago Bay Formation is an upward-shallowing succession of 
carbonate-rich sedimentary rocks deposited in intertidal/lagoonal to supratidal and restricted intertidal depositional environments (Rainbird et al., 1994). Overlying the Jago Bay Formation, the Minto Inlet Formation consists of sedimentary rocks deposited under alternating restricted and open-marine conditions as reflected in bedded gypsum deposits and shallow subtidal limestones, respectively (Rainbird et al., 1996). The overlying Wynniatt Formation, interpreted as a storm-dominated carbonate ramp, is divided into four informal members: (1) Lower Carbonate member, an upward-deepening succession of supra- to sub-tidal carbonate rocks; (2) Black Shale member, a recessive interval of dark-grey siltstone and silty shale deposited in a pro-delta setting; (3) Stromatolitic Carbonate member, comprising stacked upward-shallowing cycles of subtidal to supratidal carbonate rocks and, (4) Upper Carbonate member, an upward-shallowing succession from subtidal black calcareous shale to peritidal, cross-bedded intraclastic grainstone and stromatolitic limestone (Thomson et al., 2014). The Kilian Formation is characterized by cyclically alternating shallow sub- to intertidal carbonate rocks and sabkha-related evaporite facies (Rainbird et al., 1996).

Asmerom et al. (1991) reported several Sr isotope values for the Shaler Supergroup, however the lack of good age control hindered robust global correlation. Jones et al. (2010) published the first detailed $\delta^{13} \mathrm{C}_{\text {carb }}$ chemostratigraphic curve for the Shaler Supergroup. A negative excursion reported from the Wynniatt Formation was correlated with the global Bitter Springs stage, and a younger negative excursion documented in the Kilian Formation was tentatively correlated to the 'Islay' excursion (Brasier and Shields, 2000; Jones et al., 2010). 


\subsection{Methods}

\subsubsection{Geochemical approach to paleoredox interpretation}

A multi-proxy approach using iron speciation, redox-sensitive trace metals, and pyrite sulphur isotope ratios is applied to estimate the paleoredox conditions in the Amundsen Basin. The Fe speciation proxy provides a fingerprint for the presence of anoxic water column conditions. It is typically accepted that in average continental and slope deposits, iron that is highly reactive toward hydrogen sulphide on short time scales $\left(\mathrm{Fe}_{\mathrm{HR}}\right)$ accounts for less than $\sim 40 \%$ of the total iron $\left(\mathrm{Fe}_{\mathrm{T}}\right)$ pool (Poulton and Raiswell, 2002; Raiswell and Canfield, 1998). In contrast, stratigraphically persistent, highly reactive iron enrichments develop when there is $\mathrm{Fe}$ scavenging under an anoxic water column (Poulton and Canfield, 2011). Therefore, typical continental margin sediments with $\mathrm{Fe}_{\mathrm{HR}} / \mathrm{Fe}_{\mathrm{T}}$ ratios greater than 0.4 are interpreted to have been deposited under an anoxic water column. However, it should be noted that sediments deposited close to large anoxic zones can also have highly reactive iron enrichments (Scholz et al., 2014), but these settings are unlikely to leave a laterally and stratigraphically persistent record.

If Fe speciation data suggests that sediments were deposited under anoxic water column conditions, one can explore further whether ferruginous $\left(\mathrm{Fe}^{2+}>\mathrm{H}_{2} \mathrm{~S}\right)$ or euxinic $\left(\mathrm{Fe}^{2+}<\mathrm{H}_{2} \mathrm{~S}\right)$ water column conditions prevailed based on the ratio of pyrite $\left(\mathrm{Fe}_{\mathrm{Py}}\right)$ to $\mathrm{Fe}_{\mathrm{HR}}$. If the $\mathrm{Fe}_{\mathrm{Py}} / \mathrm{Fe}_{\mathrm{HR}}$ ratio is $>0.7$, the anoxic shales can be attributed to iron-limited, sulphide-rich (euxinic) depositional conditions, while a $\mathrm{Fe}_{\mathrm{Py}} / \mathrm{Fe}_{\mathrm{HR}}$ ratio $<0.7$ indicates ferruginous conditions (Poulton and Canfield, 2011). 
The degree of redox-sensitive trace metal enrichment (Mo, U, V) for shales deposited under euxinic conditions, based on the Fe speciation proxies, can be used to make first-order inferences about the global marine redox state (e.g. Algeo and Lyons, 2006; Lyons et al., 2009; Partin et al., 2013; Reinhard et al., 2013; Scott et al., 2008). This idea builds from three key principles. First, because these elements are more soluble under oxic than anoxic conditions, the global ratio of oxic-to-anoxic marine conditions controls the magnitude of the marine burial fluxes and ultimately the size of the dissolved Mo, $\mathrm{V}$, and $\mathrm{U}$ reservoirs in seawater. Greater extents of anoxia and euxinia decrease the sizes of the Mo, V, and U reservoirs (Emerson and Huested, 1991). Second, after the permanent rise of atmospheric oxygen during the 'Great Oxidation Event' (around 2.32 billion years ago [Ga]; Bekker et al., 2004), the source flux of these elements (e.g. oxidation of continental crust) was decoupled from atmospheric oxygen levels and remained constant (see Partin et al., 2013; Reinhard et al., 2013). This assumption is based on the low levels of atmospheric oxygen needed to oxidize sulphide minerals and to mobilize Mo, V, and U during weathering (e.g. Anbar et al., 2007; Reinhard et al., 2009). Lastly, the sizes of the Mo, V, and U marine reservoirs control the magnitudes of enrichment in euxinic sediments and rocks (e.g., Algeo and Lyons, 2006). Furthermore, because particulate organic matter sequesters $\mathrm{Mo}, \mathrm{V}$, and $\mathrm{U}$, there is strong link between particulate organic matter fluxes and Mo, V, and U burial (Algeo and Lyons, 2006). Therefore, ratios of redox-sensitive elements to total organic carbon (TOC), in combination with traditional enrichment factors, are the most effective way of tracking the size of the Mo, V, and U marine reservoirs (Lyons et al., 2009). The utility of this approach is clearly illustrated in euxinic sections that capture the onset, the middle, and 
the end of Cretaceous Ocean Anoxic Events (OAEs) (e.g. Hetzel et al., 2009), and it has been widely used to track both Phanerozoic and Precambrian redox evolution (Gill et al., 2011; Sahoo et al., 2012; Scott et al., 2008), and the extent of euxinia in the global ocean (Reinhard et al., 2013).

Light $\left({ }^{32} \mathrm{~S}\right.$-enriched) sulphur isotope compositions for pyrite $\left(\delta^{34} \mathrm{~S}_{\mathrm{py}}\right)$ indicate marine sulphate concentrations sufficiently high enough to avoid reservoir effects that can mute the ${ }^{32} \mathrm{~S}$ preference that characterizes bacterial sulphate reduction (e.g., Leavitt et al., 2013; Scott et al., 2014). Similarly, heavy $\delta^{34} S_{\text {Py }}$ values can be linked to very low marine sulphate concentrations. Low concentrations $(<1 \mathrm{mM})$ are often a consequence of widespread marine anoxia and accompanying high globally integrated rates of marine pyrite burial (Scott et al., 2014 and references therein). Locally, high fluxes of labile particulate organic matter can fuel high rates of microbial sulphate reduction, and this factor can result in small fractionations during sulphate reduction and thus relatively heavy pyrite (see Levitt et al., 2013 and references therein).

\subsubsection{Sampling}

785 samples spanning the stratigraphic interval from the Boot Inlet Formation to the Kilian Formation (Fig. 21) were collected for stable isotope analysis from measured stratigraphic sections and logged exploration drill cores. Altered thermal contact aureoles adjacent to diabase sills were avoided. Carbonate samples were cut to expose fresh surfaces and textures and microdrilled with a diamond dental drill to produce powders. Micritic microfacies were preferentially sampled, avoiding veins. Thin sections were 
prepared from all representative lithofacies for petrographic screening and description. Shale samples were also cut to expose fresh surfaces and to avoid veins and visible alteration zones, ultrasonicated with deionized water, oven dried, and pulverized in agate.

\subsubsection{Analytical methods}

$\delta^{13} \mathrm{C}_{\text {carb }}$ and $\delta^{18} \mathrm{O}_{\text {carb }}$ analyses were preformed at the G.G. Hatch Isotope Laboratory at the University of Ottawa. Samples were weighed into exetainers followed by addition of $0.1 \mathrm{~mL}$ of $\mathrm{H}_{3} \mathrm{PO}_{4}$ to the side of the exetainer. The exetainers were then helium-flushed while horizontal. Reaction at $25^{\circ} \mathrm{C}$ for $24 \mathrm{hrs}$ (calcite) or $50^{\circ} \mathrm{C}$ for $24 \mathrm{hrs}$ (dolomite) was followed by analysis in continuous flow. The measurements were performed on a Delta XP connected to a Gasbench II, both from Thermo Finnigan ${ }^{\mathrm{TM}}$. All $\delta^{13} \mathrm{C}$ and $\delta^{18} \mathrm{O}$ values are reported in delta notation relative to international standards on the Vienna-Pee Dee Belemnite (VPDB) scale. Analytical precision (2 sigma) for both carbon and oxygen isotope analyses is $+/-0.1$ permil. Data for $\mathrm{C}$ and $\mathrm{O}$ were normalized using international standards NBS-18, NBS-19, and LSVEC (C only). Quality control duplicates were analyzed at the beginning, middle, and end of each run.

$\delta^{13} \mathrm{C}_{\text {org }}$ analyses were preformed at the Stable Isotopes for Innovative Research (SIFIR) laboratory at the University of Manitoba. The concentration of total organic carbon was determined on an Eltra IR C/S analyzer as the difference between total carbon (determined by combustion) and total inorganic carbon (determined by acidification). The concentration of total sulphur was also determined on an Eltra IR C/S analyzer. For $\delta^{13} \mathrm{C}_{\text {org }}$ analyses, sample powder was weighed in a silver cup, and ultrapure $6 \mathrm{~N} \mathrm{HCl}$ was 
added to remove inorganic carbon. To improve the efficiency of sample combustion, temperature in the oxidation column was raised to $1100^{\circ} \mathrm{C}$, and a 'macro' $\mathrm{O}_{2}$ injection loop was utilized. Tin cups were used as a catalyst to increase the combustion temperature through exothermic reaction. Analyses were performed using a $\operatorname{Costech}^{\mathrm{TM}}$ 4010 Elemental Analyzer (EA) coupled to a Thermo Finnigan ${ }^{\mathrm{TM}}$ Delta V Plus isotoperatio mass-spectrometer via an open-split interface (ConFlo III, Thermo Finnigan ${ }^{\mathrm{TM}}$ ). Sample normalization was performed using the two-point calibration described in Coplen et al. (2006). Two international standards (USGS40 and USGS41) were analyzed at the beginning, middle, and end of each run. A calibration line was calculated for each run by least-squares linear regression using the known and measured isotope values of the calibration standards. To monitor the quality of sample preparation and analysis performance, the international standard USGS Green River shale SGR-1b $\left(\delta^{13} \mathrm{C}_{\text {org }}=-29.3\right.$ $\pm 0.1 \%$ V-PDB) was treated and analyzed as an unknown. Replicate analyses of SGR-1b standard yielded the $\delta^{13} \mathrm{C}_{\text {org }}$ value of $-29.5 \pm 0.1 \%$ ( $\left.\mathrm{n}=24\right)$.

Sulphur isotope analyses were also performed at the SIFIR laboratory at the University of Manitoba. Chromium-reducible sulphur (CRS), dominantly pyrite in our samples, was extracted following the method of Canfield et al. (1986). Approximately 0.3-0.5 mg of extracted $\mathrm{Ag}_{2} \mathrm{~S}$ was weighed into $\mathrm{Sn}$ cups $(5 \times 3.5 \mathrm{~mm})$, wrapped, and analyzed for S isotopes on a $\operatorname{Costech}^{\mathrm{TM}} 4010$ Elemental Analyzer (EA) coupled to a Thermo Finnigan ${ }^{\mathrm{TM}}$ Delta V Plus isotope-ratio mass-spectrometer (IRMS) via an opensplit interface (ConFlo IV, Thermo Finnigan ${ }^{\mathrm{TM}}$ ). In the EA, the sample Sn cup was dropped in a helium flow to the $1^{\text {st }}$ reaction column, containing oxidation and reduction chemicals at $1050^{\circ} \mathrm{C}$ and a 'macro' $\mathrm{O}_{2}$ injection loop was utilized. The produced $\mathrm{SO}_{2}$ 
passed through the $2^{\text {nd }}$ reaction column at $890^{\circ} \mathrm{C}$, containing quartz chips. This was done to minimize the uncertainty in corrections related to oxygen isotopes (Fry et al., 2002). All S isotope ratios are reported in delta notation relative to international standards on the VCDT scale. Sample normalization was performed using the two-point calibration described in Coplen et al. (2006). Three international standards (IAEA-S1, IAEA-S2, and IAEA-S3) were analysed at the beginning, middle, and end of each run. A calibration line was calculated for each run by least-squares linear regression using the known and measured isotope values of the calibration standards. To monitor the quality of sample preparation and analysis performance, one internal sulphide standard (Maine Light $\left.\left(\mathrm{Ag}_{2} \mathrm{~S}\right), \delta^{34} \mathrm{~S}=-30.9 \pm 0.4 \% \mathrm{VCDT}, \mathrm{n}=24\right)$ was treated and analysed as an unknown. Replicate analyses of the quality-check standard yielded the $\delta^{34} \mathrm{~S}$ value of $-31.1 \pm 0.3 \%$ $(n=7)$.

The sequential Fe extractions were performed at the Biogeochemistry Lab at the University of California, Riverside, following well-established techniques (e.g. Reinhard et al., 2009). The pyrite $\mathrm{Fe}$ concentrations $\left(\mathrm{Fe}_{\mathrm{py}}\right)$ were calculated, assuming a pyrite stoichiometry, using the CRS concentrations determined at the SIFIR laboratory. Approximately $100 \mathrm{mg}$ of fresh sample were used following the Poulton and Canfield (2005) sequential Fe speciation technique. Iron concentrations for the solutions were measured with an Agilent 7500 inductively coupled plasma mass spectrometer (ICP-MS). Aluminum concentrations were also measured for each extract to monitor Fe contribution from less reactive silicates and it was found to be less than $0.1 \%$. ICP-MS precision and accuracy were monitored with multi-element standards and a geostandard (USGS-SDO1). Drift within a run led to less than $5 \%$ error. Duplicate measurements, within the same 
or multiple ICP-MS runs, agreed within 7\%. The sequential Fe procedure isolates the following operationally defined Fe fractions: (1) Na-acetate Fe representing carbonatebound $\mathrm{Fe}$, herein referred to as $\mathrm{Fe}_{\text {carb }}$; (2) $\mathrm{Na}$ dithionite Fe representing crystalline oxides such as goethite and hematite, herein referred to as $\mathrm{Fe}_{\mathrm{ox}}$; and (3) oxalate $\mathrm{Fe}$ representing magnetite, herein referred to as $\mathrm{Fe}_{\mathrm{mag}}$. Combined, $\mathrm{Fe}_{\mathrm{py}}, \mathrm{Fe}_{\mathrm{carb}}, \mathrm{Fe}_{\mathrm{ox}}$, and $\mathrm{Fe}_{\mathrm{mag}}$ represent the 'highly reactive' Fe pool $\left(\mathrm{Fe}_{\mathrm{HR}}\right)$.

Major and minor element concentrations were measured at ACME Analytical Laboratories Ltd using ICP-MS analysis after multi-acid digestion. Accuracy and precision were monitored with duplicate analyses and a blind shale geostandard (USGS SGR1b). ACME Analytical Laboratories uses a quality monitoring system compliant with the International Standards Organization (ISO) 9001 Model for Quality Assurance and ISO/IEC 17025 General Requirements for the Competence of Testing and Calibration Laboratories. Further details are available from ACME Analytical Laboratories, Vancouver, British Columbia.

\subsection{Results and Basic Data Interpretations}

\subsubsection{Carbon isotopes and carbonate sedimentology}

\subsubsection{Carbon isotopes}

The carbon isotope curve for the upper Shaler Supergroup (Fig. 21) represents a composite of 19 measured sections and three drill cores logged and sampled from the southwest and northeast portions of the Minto Inlier (Fig. 1); see supplementary data for a complete set of tabulated data. $\delta^{13} \mathrm{C}_{\text {carb }}$ values range from -14.3 to $+7.7 \%$, although 

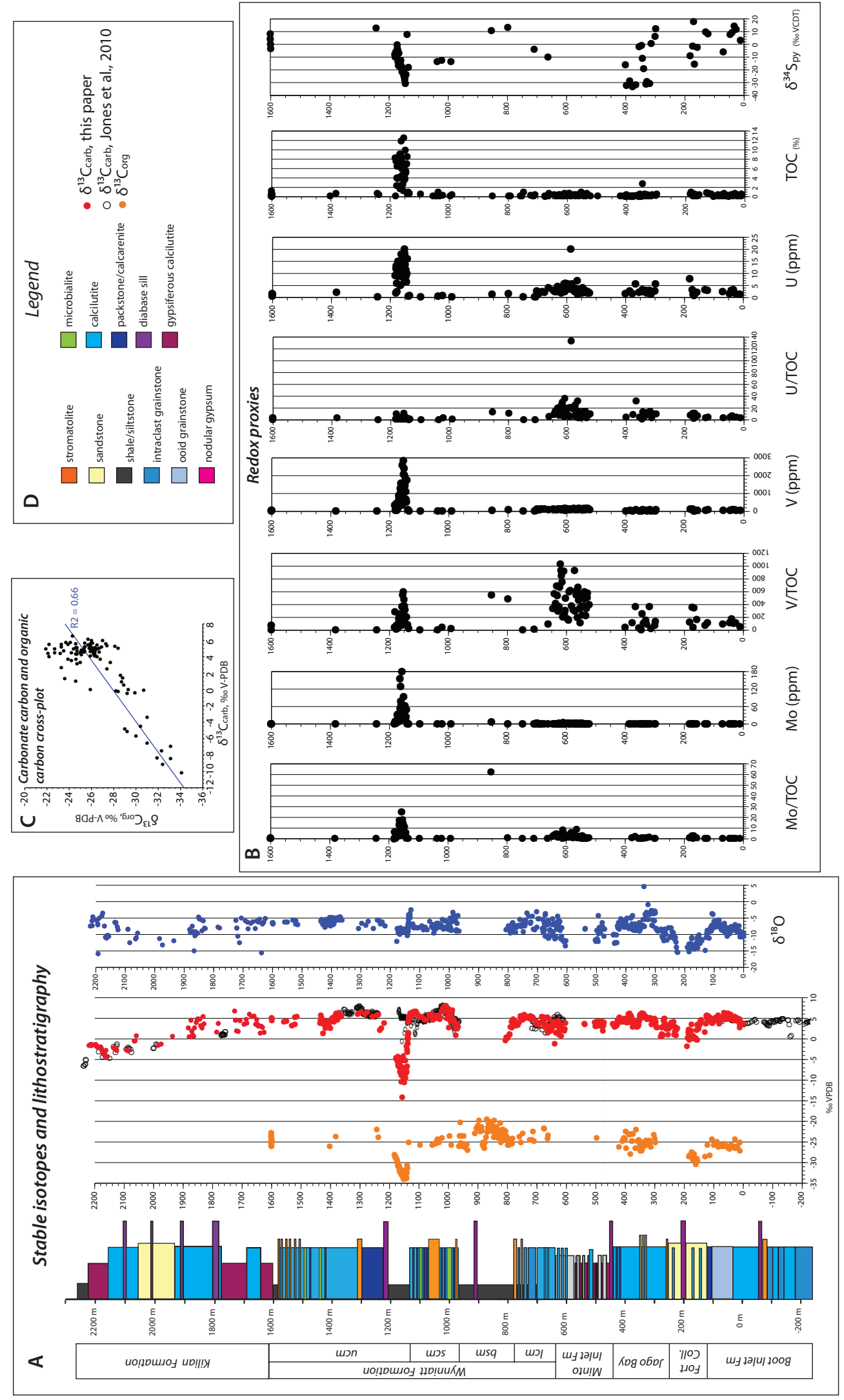

Figure 21. Composite section of the upper Shaler Supergroup. A) $\delta^{13} \mathrm{C}_{\text {carb }}, \delta^{13} \mathrm{C}_{\mathrm{org}}$, and $\delta^{18} \mathrm{O}$ values are shown. Open black circles are data from Jones et al. (2010). B) Mo, V, U (in ppm), Mo, V, and U (normalized to TOC), TOC, and $\delta^{34} \mathrm{~S}_{\mathrm{py}}$ data. C) Cross-plot of $\delta^{13} \mathrm{C}_{\text {carb }}$ and $\delta^{13} \mathrm{C}_{\text {org }}$ values. D) Legend. VPDB - Vienna Pee Dee Belemnite, VCDT - Vienna Canyon Diablo Troilite, TOC - total organic carbon.

most samples fall within a range of $\sim 0-+5 \%$, with an average value of $+3.0 \%$, which is 
a baseline for the Neoproterozoic (e.g. Halverson et al., 2010). Negative deviations occur within the Boot Inlet Formation, the Fort Collinson Formation, the Upper Carbonate member of the Wynniatt Formation, and the upper Kilian Formation (Fig. 21). The most dramatic of these is the negative excursion preserved in the Upper Carbonate member (Wynniatt Formation), where multiple $\delta^{13} \mathrm{C}_{\text {carb }}$ values ranging from $\sim-10$ to $-14 \%$ are recorded, which are well below the mantle value of -5 to $-6 \%$.

$\delta^{13} \mathrm{C}_{\text {org }}$ values average $-25.9 \%$ but range from -34.2 to $-14.4 \%$. $\delta^{13} \mathrm{C}_{\text {carb }}$ and $\delta^{13} \mathrm{C}_{\text {org }}$ values co-vary throughout the sampled intervals (Fig. 21). A cross-plot of $\delta^{13} \mathrm{C}_{\text {carb }}$ versus $\delta^{13} C_{\text {org }}$ values displays good correlation $\left(R^{2}=0.66\right.$, Fig. 21$)$, although values cluster more tightly around the line of best fit for the more negative part of the dataset, with a greater spread in data for the samples with the most positive $\delta^{13} \mathrm{C}_{\text {carb }}$ values. In the traditional framework of interpretation, this would indicate that the $\mathrm{C}_{\text {org }}$ was derived and fractionated from the same contemporaneous dissolved inorganic carbon captured in the carbonate carbon isotope values (e.g., Knoll et al., 1986; Kump et al., 2011; SwansonHysell et al., 2010).

\subsubsection{Sedimentology and stratigraphy of the negative excursion stratigraphic interval}

The stratigraphic interval marked by the large negative excursion in the Upper Carbonate member consists predominantly of laminated, carbonaceous calcareous black shale (Fig. 20b and c) representing sedimentation below storm wave-base (SWB) on the outer slope (Thomson et al., 2014). Thin beds of normally graded calcarenite, interpreted as turbidites, are interbedded within the shale. Although the carbonate beds are composed 
largely of transported material, grains are cemented in a micritic diagenetic matrix (Fig. 20e). There are also carbonate-rich nodules within the shales, which formed in situ during early diagenesis as indicated by enveloping shale, which is warped around the nodules by later differential compaction (Fig. 20a). Early seafloor dissolution and cementation is visible along bedding contacts as irregular surfaces that are buckled or micro-fractured and are draped by overlying shale. Where deformed, pore space is filled by blocky, subhedral, cloudy, non-equidimensional calcite cement. All secondary features, including nodules, fractures, and blocky cement, were avoided during sampling for chemostratigraphy.

An erosional surface separates underlying, shallow-marine carbonate rocks from the interval of deep-water, black, nodular, calcareous shale, and likely represents a sedimentary hiatus (Thomson et al., 2014). The surface is coincident with the boundary between the Stromatolitic Carbonate and Upper Carbonate members (Fig. 21), and the overlying shale represents a major marine transgression. The negative $\delta^{13} \mathrm{C}_{\text {carb }}$ excursion is preserved in this shale (Fig. 20d).

\subsubsection{Paleoredox proxies}

Most of the data collected from our composite section are too sparse and ambiguous to support confident interpretations about paleoredox conditions. A carbonaceous shale interval in the Upper Carbonate member is the stand-alone exception (Figs. 20 and 22). It is likely though that the majority of the studied interval contains sediments deposited in oxic settings, as the lithologies and sedimentary structures indicate deposition in shallow-marine to emergent conditions (Rainbird et al., 1996; Thomson et al., 2014). The only interval that preserves slightly deeper sedimentation in 
the upper Shaler Supergroup is the Black Shale member of the Wynniatt Formation, which was deposited below fair-weather wave-base, but above storm wave-base (Thomson et al., 2014), under oxic to suboxic conditions (Lafond, 2011).

Several redox proxies point to deposition of the carbonaceous shale interval in the lower part of the Upper Carbonate member under euxinic conditions (Fig. 22). $\mathrm{Fe}_{\mathrm{HR}} / \mathrm{Fe}_{\mathrm{T}}$ ratios are well above 0.4, indicating anoxic conditions, and furthermore $\mathrm{Fe}_{\mathrm{Py}} / \mathrm{Fe}_{\mathrm{HR}}$ ratios above 0.7 indicate euxinic conditions (Fig. 22). There are also significant enrichments in 


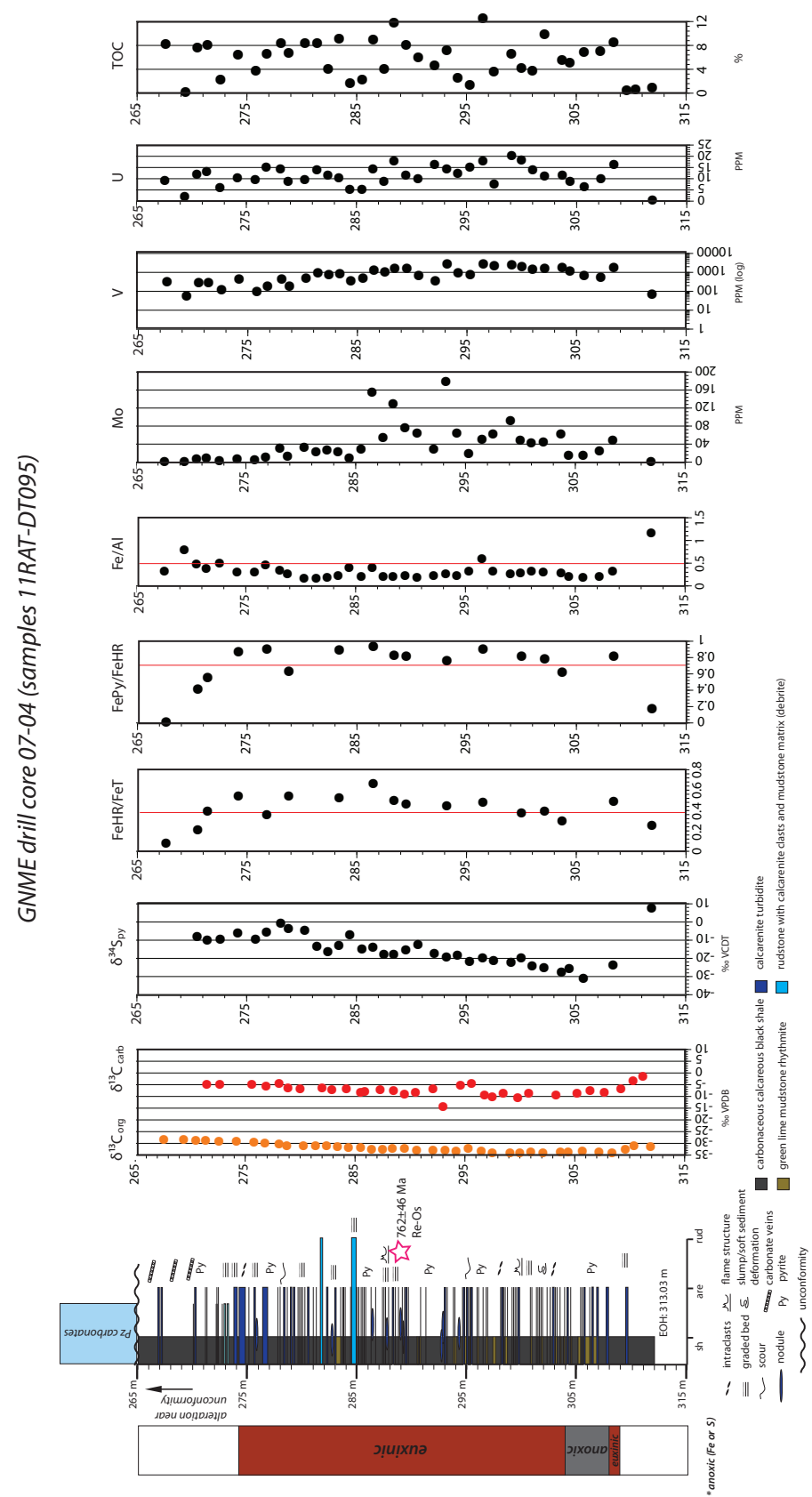

Figure 22. Geochemical data from drill core GNME 07-04 spanning the Bitter Springs stage. Interpretation of paleoredox conditions is shown beside the stratigraphic section. The typical continental margin baseline for Fe speciation parameters is indicated by the vertical red lines. Note: the location of this core is indicated on Fig. 1 by a black star, and the $\mathrm{V}$ data is presented using a log scale. Re-Os age is from van Acken et al. (2013). EOH - end of hole, sh - shale, are - arenite, rud - rudstone, VPDB - Vienna Pee Dee Belemnite, VCDT - Vienna Canyon Diablo Troilite, PPM - parts per million. 
Mo (up to $179 \mathrm{ppm}$ ), V (up to $2826 \mathrm{ppm}$ ), and U (up to $20.1 \mathrm{ppm}$ ), comparative to continental crust averages of $1.1 \mathrm{ppm}, 98 \mathrm{ppm}$, and $1.7 \mathrm{ppm}$, respectively (Wedepohl, 1995). High Mo enrichments independently corroborate the euxinic conditions suggested by the Fe proxy data (see Scott and Lyons, 2012).

Given that the Upper Carbonate member shales were deposited under euxinic conditions, the Mo, $\mathrm{V}$, and $\mathrm{U}$ enrichments can shed light on broader marine redox conditions (cf. Scott et al., 2008). The Mo enrichments in the carbonaceous shale interval of the Upper Carbonate member are elevated relative to the mean value for the midProterozoic (2.0-0.74 Ga) euxinic shale $(40.5 \pm 22.5 \mathrm{ppm}$ at the $95 \%$ confidence level), and are comparable to the mean value for Phanerozoic euxinic shale $(170.2 \pm 33.4 \mathrm{ppm}$ at the 95\% confidence level; Reinhard et al., 2013). The elevated Mo to TOC ratios from the euxinic shale interval in our study are comparable to mid-Proterozoic ratios $(<100$ ppm/wt \%) and lower than Phanerozoic ratios (>100 ppm/wt \%; see Sahoo et al., 2012). $\mathrm{U}$ enrichments and U/TOC ratios are similar to those recorded in other Mesoproterozoic and early Neoproterozoic successions (Fig. 22; cf. Partin et al., 2013). The V enrichments and V/TOC ratios, in contrast, are well above the typical Proterozoic values and similar to Phanerozoic values (cf. Sahoo et al., 2012). Additionally, the Mo, U, and V enrichments are notably higher than those measured in the younger Walcott member of the Chuar Group (Dahl et al., 2011).

There are light $\delta^{34} \mathrm{~S}$ values in the Upper Carbonate member, with the lowest $\delta^{34} \mathrm{~S}$ values below $-35 \%$. Assuming that at no point in the Cryogenian does sulphate $\delta^{34} \mathrm{~S}$ $\left(\delta^{34} \mathrm{~S}_{\mathrm{SO} 4}\right)$ drop below $+10 \%$ (Halverson et al., 2010), the $\Delta^{34} \mathrm{~S}\left(\delta^{34} \mathrm{~S}_{\mathrm{SO} 4}-\delta^{34} \mathrm{~S}_{\mathrm{pyr}}\right)$ values in the Upper Carbonate member are commonly greater than $45 \%$, which is unusually high 
for Precambrian euxinic shales (Scott et al., 2014). Given euxinic depositional conditions and the absence of macroscopic sulphides, finely-disseminated pyrite in the analysed samples (Fig. 20c) is likely to be depositional (e.g., Lyons, 1997). These highly negative

$\delta^{34} \mathrm{~S}$ values of pyrite indicate a water column where sulphate was not limiting, allowing for preferential microbial utilization of ${ }^{32} \mathrm{~S}$ during dissimilatory sulphate reduction. This relationship suggests mM-level seawater sulphate concentrations (cf. Scott et al., 2014). On a longer time scale, there is a broad trend towards more negative $\mathrm{S}$ isotope values from the Boot Inlet Formation to the Jago Bay Formation, followed by a highly variable trend towards more positive $\mathrm{S}$ isotope values through the Wynniatt Formation with a notably sharp rise in the lower part of the Upper Carbonate member, after which $\mathrm{S}$ isotope values hover at $\sim 0 \%$ (Fig. 21 ). Given that the pyrite in our samples formed under a range of redox conditions (e.g., in the water column under euxinic conditions and in pore waters beneath oxic bottom waters), it is speculative to interpret the environmental or geochemical significance of this trend.

\subsection{Discussion}

\subsubsection{Testing existing correlations with new chemostratigraphic data}

While most of the $\delta^{13} C_{\text {carb }}$ values through the sampled portion of the Shaler Supergroup are positive and range from $\sim 2$ to $+5 \%$, within the Boot Inlet Formation,

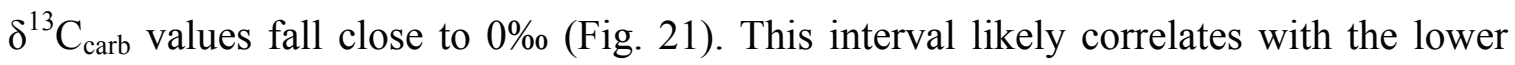
Stone Knife/Silverberry formations of the Mackenzie Mountains Supergroup, Mackenzie Mountains, and the Gibben Formation of the Fifteenmile Group, Ogilvie Mountains (Fig. 
23), where similar values were reported. While data from this stratigraphic interval in our study area is limited, this inference is consistent with previous stratigraphic correlations based on litho- and sequence stratigraphy (Long et al., 2008; Macdonald et al., 2012; Rainbird et al., 1996; Young et al., 1979).

There is a drop in $\delta^{13} \mathrm{C}_{\text {carb }}$ values in the Fort Collinson Formation extending into the lower part of the Jago Bay Formation (Fig. 23; highlighted in grey). This decrease occurs within a siliciclastic-rich stratigraphic interval composed of cross-bedded quartz arenites and dolomitic quartz arenites (Rainbird et al., 1994). Values for $\delta^{13} \mathrm{C}_{\text {carb }}$ range from $\sim-1$ to $+6 \%$ through the Jago Bay and Minto Inlet formations and the lower part of the Wynniatt Formation. The magnitude of variability in the $\mathrm{C}$ isotope curve appears to be enhanced in our study area when compared to the Fifteenmile Group and the Mackenzie Mountains Supergroup (Fig. 23), likely due to lower sedimentation rates in the Amundsen Basin (Thomson et al., in review). The $\delta^{13} \mathrm{C}_{\text {carb }}$ and $\delta^{18} \mathrm{O}_{\text {carb }}$ values co-vary through this interval (Fig. 21), which is typically interpreted as a signal of alteration (e.g., Derry, 2010b; for alternative view see Bjerrum and Canfield, 2011). Further, carbon isotope values in dolomitic quartz arenites, as for the Fort Collinson Formation, commonly do not reflect the isotopic composition of the marine DIC reservoir (Knauth and Kennedy, 2009). Given these potential concerns, the $\delta^{13} \mathrm{C}_{\text {carb }}$ trend in this stratigraphic interval cannot be confidently used to make detailed chemostratigraphic correlations with sedimentary successions in other basins.

One of the outstanding questions posed by Jones et al. (2010) was whether the negative excursion present in the Upper Carbonate member of the Wynniatt Formation 
was the result of fluid alteration at the contact with a thick diabase sill that intruded the

1. Ogilvie Mountains, Fifteenmile Group

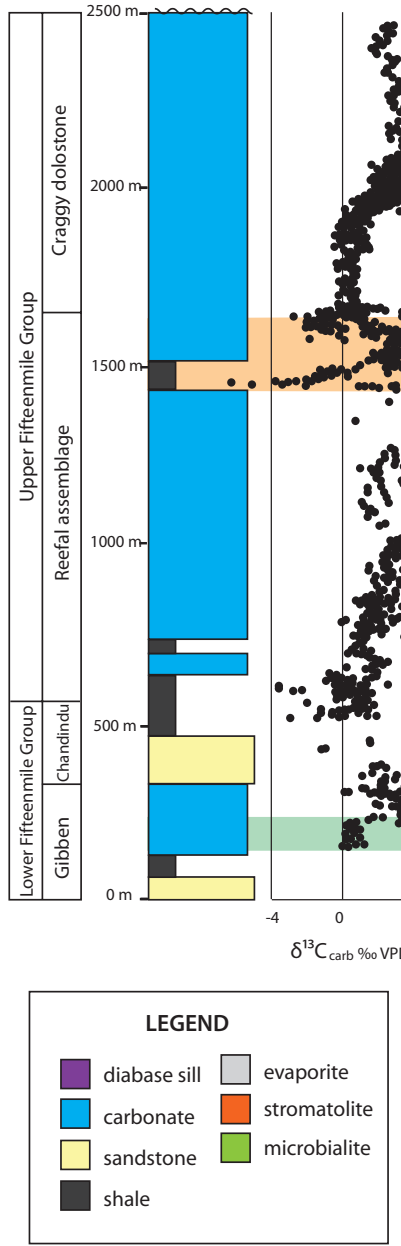

2. Mackenzie Mountains,

Mackenzie Mountains Supergroup

\section{Victoria Island, \\ Shaler Supergroup}


strata at their sampling location. Where we sampled that horizon, both in core and outcrop, 86 and $150 \mathrm{~km}$ away, respectively, from the section Jones et al. (2010) sampled (Fig. 1), a similar excursion is preserved. There are no sills in, or adjacent to, our sections, and the presence of this negative excursion in all three localities sampled confirms that negative $\delta^{13} \mathrm{C}_{\text {carb }}$ values in the Upper Carbonate member of the Wynniatt Formation are present throughout the basin. Jones et al. (2010) tentatively linked these negative $\delta^{13} \mathrm{C}_{\text {carb }}$ values to the roughly coeval Bitter Springs isotopic stage.

The Bitter Springs isotopic stage follows two positive peaks in the $\delta^{13} \mathrm{C}_{\text {carb }}$ record that occur prior to the downturn that defines the negative excursion, first recognized and thus named for the Bitter Springs Formation from the Amadeus Basin, Australia (Hill and Walter, 2000). Where this excursion has been reported in other successions, there is an abrupt shift to negative values of $\sim-4 \%$, and then the trend gradually recovers and returns to positive values, producing an asymmetric curve (e.g., Halverson, 2006; Halverson et al., 2007b; Macdonald et al., 2010; Swanson-Hysell et al., 2010). $\delta^{13} \mathrm{C}_{\text {carb }}$ and $\delta^{13} \mathrm{C}_{\text {org }}$ values co-vary where they previously were measured through the Bitter Springs excursion (e.g., Swanson-Hysell et al., 2010).

The carbon isotope trend in the Upper Carbonate member of the Wynniatt Formation is likely to represent the Bitter Springs isotopic stage. Foremost, the double positive peak preceding the Bitter Springs isotopic stage is clearly defined in the Wynniatt Formation. However, the highly negative values in the Upper Carbonate member are more difficult to interpret, given that they occur in deeper-water facies, and $\mathrm{C}$ isotope values are much lighter than those reported from other localities. Authigenic carbonate phases are likely to have $\delta^{13} \mathrm{C}_{\text {carb }}$ values that reflect pore water compositions 
rather than overlying seawater DIC values. However, beds composed largely of transported detrital carbonate still have negative $\delta^{13} \mathrm{C}_{\text {carb }}$ values, which suggests that the negative $\delta^{13} \mathrm{C}_{\text {carb }}$ values are at least partially linked to a drop in surface marine $\delta^{13} \mathrm{C}_{\text {DIC }}$ values, unless they have been completely diagenetically reset. The very negative $\delta^{13} \mathrm{C}_{\text {carb }}$ values in this interval $(<-6 \%$ ) likely reflect lithologies more strongly affected by authigenic carbonate. We return to a discussion of the origin of the negative $\delta^{13} \mathrm{C}_{\text {carb }}$ values in section 4.5.2.

Assuming that the Upper Carbonate member of the Wynniatt Formation is correlative to the Bitter Springs isotopic stage, there is an apparent discrepancy in the two available ages for this stage. An age of $811.5+/-0.25 \mathrm{Ma}$ was reported from a tuff from the Fifteenmile Group in the Ogivlie Mountains (Macdonald et al., 2010), while our study area has an age of $761 \pm 41 \mathrm{Ma}$ from Re-Os dating of black shale (Van Acken et al., 2013). This difference can easily be explained however, as the ca. 811 Ma tuff occurs $\sim 50 \mathrm{~m}$ stratigraphically below the onset of the decrease in $\delta^{13} \mathrm{C}_{\mathrm{carb}}$ values in the Fifteenmile Group (Macdonald et al., 2012; Macdonald et al., 2010), while the ca. 761 Ma age occurs within the negative excursion in the Wynniatt Formation, specifically, 25 $\mathrm{m}$ above the base of the excursion, near the inflection point where values begin to increase. Also, some of the discrepancy may relate to the observation that the ca. $761 \mathrm{Ma}$ age comes from a stratigraphic interval of black shale deposited on the outer slope where sediment accumulation rates are slow and compaction is great. In addition, at both localities, the Bitter Springs stage occurs in successions directly overlying sequence boundaries (Macdonald et al., 2012; Thomson et al, in review). In the Ogilvie Mountains, it overlies a transgressive-regressive sequence boundary that occurs above the dated tuff 
(Macdonald et al., 2012; Fig. 5), and directly overlies an unconformity in the Minto Inlier (Thomson et al., 2014). As the ca. 811 Ma age comes from the strata below an unconformity and below the Bitter Springs stage, it implies a further loss of time between the dated horizon and the strata that host the isotope excursion. One must also consider the large error on the $761 \pm 41$ Ma Re-Os age (Van Acken et al., 2013), and so the sampled interval may be as old as $802 \mathrm{Ma}$. Further complicating matters, basalts of the Johnny's Creek Member of the Bitter Springs Formation, considered to belong to the same mantle plume event as the $827 \pm 6$ Ma Gairdner Dyke Swarm (Wingate et al., 1998) based on similar trace element geochemistry (Zhao et al., 1994), directly overlie the Love's Creek Member, the type section for the Bitter Springs Stage. Clearly, additional work combining precise geochronology and chemostratigraphy is needed to resolve this issue and to test the idea that the Bitter Springs Stage is globally contemporaneous phenomena.

After recovery of $\delta^{13} C_{\text {carb }}$ values above the Bitter Springs stage, there is a steady decrease in $\delta^{13} \mathrm{C}_{\text {carb }}$ values down to $\sim-5 \%$ through the Kilian Formation. This trend was originally reported by Jones et al. (2010), who interpreted the negative excursion to be correlative with the pre-Sturtian, "Islay" excursion (Brasier and Shields, 2000) on the basis of: (1) similar trend and amplitude, (2) the relative age of the Kilian Formation, and (3) because they sampled sedimentary rocks recording the excursion in an outcrop capped by a diamictite. We have not observed this diamictite; however, the age of this excursion is consistent with the notion of equivalence to the Islay excursion, as the age of the Kilian Formation is bracketed by the Re-Os age of the underlying Wynniatt Formation $(761+/$ $41 \mathrm{Ma}$; Van Acken et al., 2013) and the $723+4 /-2 \mathrm{Ma} \mathrm{U}-\mathrm{Pb}$ age of crosscutting sills 
(Heaman et al., 1992). We agree with the correlation of Jones et al. (2010), who correlated the Kilian Formation to the Coates Lake Group, which is also considered correlative with the Callison Lake dolostone of the Mount Harper Group of the Ogilvie Mountains (Macdonald et al., 2012). Importantly, this chemostratigraphy-based correlation supports earlier correlations based on litho- and sequence stratigraphy (Aitken et al., 1978; Rainbird et al., 1996; Young et al., 1979).

\subsubsection{Negative carbon isotope anomalies: Evaluation of the different mechanisms and an interpretation for the Amundsen Basin}

Determining the significance of highly negative $\delta^{13} \mathrm{C}_{\text {carb }}$ values, below those of the mantle carbon, is essential to our understanding of the evolution of Earth surface processes during the Neoproterozoic. There are several differing interpretations of negative shifts in $\delta^{13} \mathrm{C}$ values: (1) resetting during early diagenesis; for example, during a drop in sea-level whereby meteoric waters are flushed through the carbonate platform, driving C isotope values down (Knauth and Kennedy, 2009; Swart and Kennedy, 2012);

(2) resetting during burial diagenesis as a result of rock-fluid interaction (Derry, 2010a, b); (3) that $\mathrm{C}$ isotope values record primary seawater chemistry whereby fluctuations were caused by changes in the global carbon cycle through, for example, the oxidation of a large pool of dissolved organic carbon (DOC; Jiang et al., 2007; Schrag et al., 2002; Swanson-Hysell et al., 2010) or methane released by destabilization of methane clathrates (Bjerrum and Canfield, 2011; Dickens et al., 1997; Jiang et al., 2003); and (4) fluctuations were caused by precipitation of authigenic carbonate from sediment porefluids during early diagenesis (Schrag et al., 2013). We add to this discussion by 
evaluating the applicability of each of these models to the negative $\delta^{13} \mathrm{C}$ anomaly in the Upper Carbonate member of the Wynniatt Formation, which likely records the Bitter Springs isotope stage.

\subsubsection{Early meteoric diagenesis}

The Bitter Springs stage is preserved in carbonaceous, calcareous shales that occur stratigraphically above a sequence boundary within sediments that were deposited during a transgression (see Thomson et al., 2014). If meteoric fluids were indeed responsible for the negative carbon isotope excursion, one would expect, in contrast, to see the negative values preserved in the carbonates below the sequence boundary, reflecting a time when sea-level was at its lowest, and drawdown of meteoric fluids would have flushed fluids with isotopically light carbon through the carbonate platform; not in the transgressive sediments above the sequence boundary as is the case in the Wynniatt Formation.

\subsubsection{Burial diagenesis}

The Bitter Springs stage is reported from stratigraphic sections on several continents, although its age remains poorly constrained. If deep burial diagenesis caused the Bitter Springs anomaly, then it must have affected a number of sections synchronously, which seems highly unlikely. Even in the Amundsen Basin, the negative anomaly is recorded in three sections that form a transect of $>150 \mathrm{~km}$ in length. Further, the $\delta^{13} \mathrm{C}_{\text {carb }}$ and $\delta^{13} \mathrm{C}_{\text {org }}$ trends are coupled, which would not be expected if the carbonate 
$\mathrm{C}$ isotope values were diagenetically reset at the burial stage (Jiang et al., 2012). Close co-variation between the $\delta^{13} \mathrm{C}_{\mathrm{carb}}$ and $\delta^{13} \mathrm{C}_{\text {org }}$ values is commonly used as the strongest argument against diagenetic alteration (Sansjofre et al., 2011).

\subsubsection{3a Change in primary seawater chemistry by oxidation of organic matter}

Considering that the $\delta^{13} \mathrm{C}_{\text {carb }}$ record is primary, one way to explain $\delta^{13} \mathrm{C}_{\text {carb }}$ fluctuations is by inferring change in the rate of burial of organic carbon relative to total carbon (e.g. Hayes et al., 1999), which has already been proposed as a mechanism for sustained positive $\delta^{13} \mathrm{C}_{\text {carb }}$ values through the Neoproterozoic (e.g. Holland, 1984; Knoll et al., 1986). In a deviation from this traditional view, some authors have attributed the markedly negative excursions in $\mathrm{C}$ isotope values of the Neoproterozoic carbonates to the oxidation of a large DOC pool (e.g. Fike et al., 2006; Jiang et al., 2007; Rothman et al., 2003; Schrag et al., 2002; Swanson-Hysell et al., 2010). However, this possibility has been challenged on the basis that DOC oxidation would rapidly consume all oxidants in the atmosphere-ocean system and would dramatically increase atmospheric $\mathrm{CO}_{2}$ (Bristow and Kennedy, 2008; Schrag et al., 2013). Although our data do not bear directly on this interpretation, based on the arguments presented above oxidation of DOC seems unlikely to be the sole explanation for the markedly negative $\delta^{13} \mathrm{C}_{\text {carb }}$ excursion.

\subsubsection{3b Release of methane clathrates}

Dissipation of methane clathrate reservoirs has been inferred to explain negative carbon isotope excursions in seawater composition, for example in association with 
'Snowball Earth' glaciations (Schrag et al., 2002), and fluctuations in the Neoproterozoic and younger (e.g. Paleogene) carbon cycle (Bjerrum and Canfield, 2011; Dickens, 2003). Sustained positive $\delta^{13} \mathrm{C}_{\text {carb }}$ values in the underlying carbonate rocks of the Shaler Supergroup (Fig. 21) and in the carbon isotope record leading to the Bitter Springs stage, in general indicate high relative burial rates of organic carbon globally (cf. Hayes et al., 1999 and references therein), a condition favourable to methane production during diagenesis. Some of this methane likely escaped to the ocean and atmosphere, where it was oxidized, but some may have trapped in the sediments forming methane clathrates. A subsequent dissipation of the methane clathrate reservoir could result in water column deoxygenation, as well as the source of isotopically light carbon (methane $\delta^{13} \mathrm{C} \sim-60 \%$; Kvenvolden, 1993) to produce a negative carbon isotope excursion.

\subsubsection{Precipitation of authigenic carbonate}

Carbonate can be precipitated from sedimentary pore fluids during very early diagenesis in association with reduction of iron and sulphate, primarily through the oxidation of methane or organic carbon, and provides a sink for isotopically light carbon in the carbon cycle (Schrag et al., 2013). Bacterially mediated oxidation of organic carbon produces $\delta^{13} \mathrm{C}$ values of approximately $-25 \%$, which is then incorporated into carbonate (see Irwin et al., 1977). In Proterozoic carbonates it can be difficult to identify authigenic carbonate petrographically since almost all of the carbonate has been neomorphosed to microspar, and dolomite replacement is common. Carbonate in the stratigraphic interval that records the highly negative carbon isotope values contains calcarenite layers that are interpreted to have been transported to the outer slope by 
turbidity currents (Thomson et al., 2014; Fig. 2). The allochems are encased in carbonate cement, precipitated in situ during early diagenesis (Fig. 20e). We were unable to analyze the allochems and cement separately, but assuming that the carbonate sand was sourced from shallower settings, it likely records the global seawater signature, while the cement precipitated in situ likely records local pore-water chemistry.

\subsubsection{Synthesis: Interpretation for the Amundsen Basin}

The negative carbon isotope anomaly in the Upper Carbonate member of the Wynniatt Formation far exceeds that in other sections recording the Bitter Springs stage, and therefore requires a local mechanism for amplification. We interpret the negative $\mathrm{C}$ 

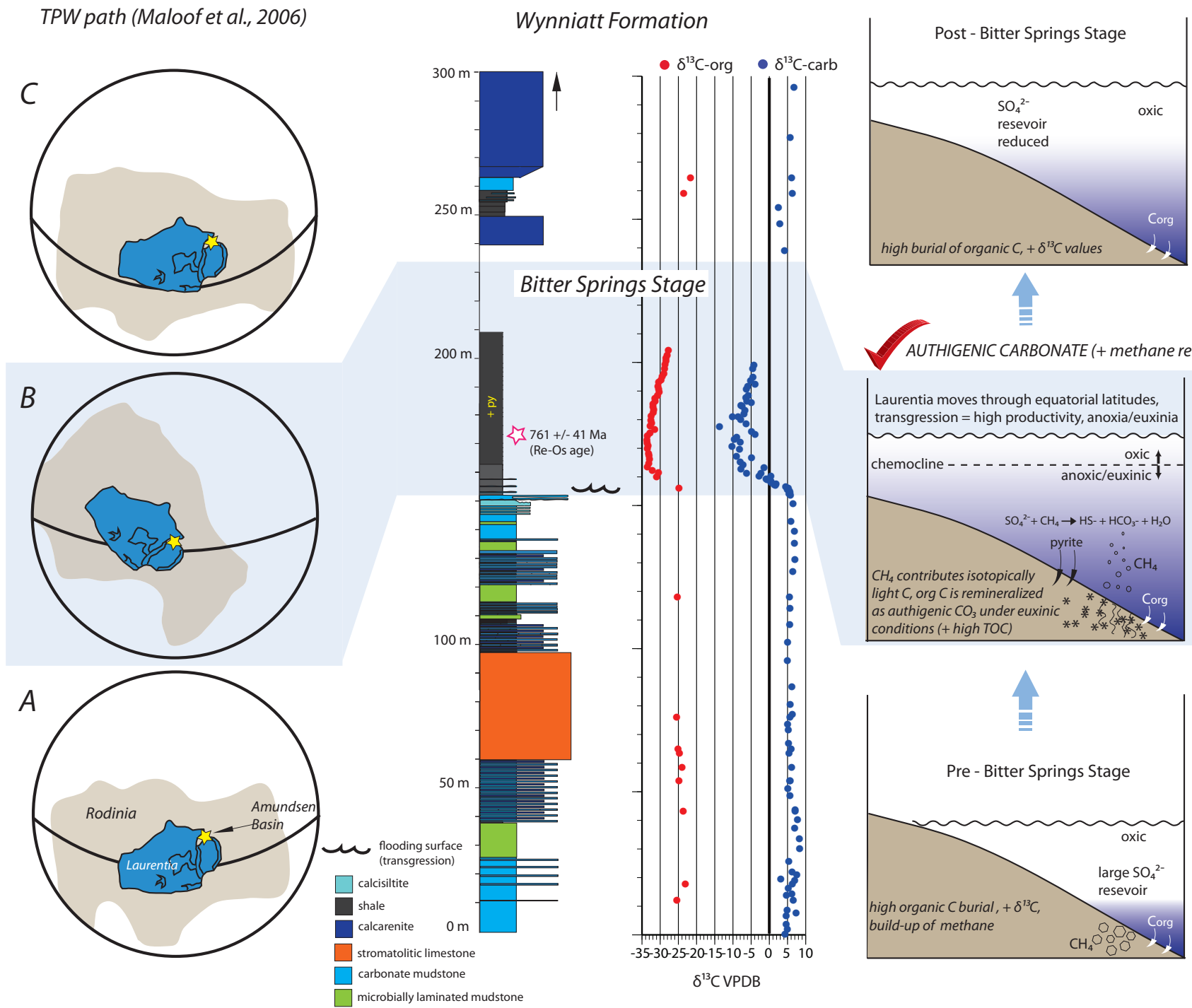

Figure 24. Schematic diagram representing our interpretation of events that led to the negative carbon isotope excursion in the Wynniatt Formation, and how they relate to global tectonics, sea-level changes, and basin-scale to global seawater composition. Before the Bitter Springs stage waters were oxygenated, there was a large seawater sulphate reservoir, and high relative rates of organic carbon burial resulted in a positive $\delta^{13} \mathrm{C}_{\text {carb }}$ excursion and buildup of methane clathrates in the sediments. During the Bitter Springs stage, a transgression occurred in the Amundsen Basin as Laurentia rotated, positioning the basin at equatorital latitudes and increasing local productivity. At the same time, basin restriction resulted in local anoxic to euxinic conditions. Methane clathrates reacted with the seawater oxidants, and contributed light carbon to DIC pool. This signal was further amplified in pore waters, where methane and organic matter were oxidized driving precipitation of authigenic carbonate cement with highly negative carbon isotope values. After the Bitter Springs stage, settings returned to previous conditions. TWP - true polar wander, py - pyrite, VPDB - Vienna Pee Dee Belemnite. 
isotope excursion as follows (see Fig. 24). During deposition of the Upper Carbonate member, the Amundsen Basin became partially restricted from the open ocean (Thomson et al., 2014). However, the well-mixed, oxygenated surface waters likely were still in open communication with the ocean, and sediments precipitated in shallow-water environments would have recorded the $\mathrm{C}$ isotope composition of the global DIC pool. High relative burial rates of organic carbon that led to the sustained positive $\delta^{13} \mathrm{C}$ values of seawater recorded in the underlying carbonate rocks of the Shaler Supergroup would also have facilitated build-up of methane in sediments. A proposed true polar wander event at ca. $800 \mathrm{Ma}$ (Maloof et al., 2006) rotated Laurentia closer to the equator, resulting in a transgression as the continent moved through the equatorial bulge, and increased productivity in the Amundsen Basin. Continents that were transported to high latitudes experienced destabilization of methane clathrates along their margins in association with relative sea-level fall (Fig. 24). The released methane would have been oxidized by a large seawater sulphate reservoir accumulated by that time (Prince, 2014), shifting marine $\delta^{13} \mathrm{C}_{\mathrm{DIC}}$ composition to negative values, and causing the significant reduction in ocean sulphate concentration that occurred between deposition of the Minto Inlet and Kilian formations (Prince, 2014). In deep-water environments (below storm wave-base), isotopically light carbon in pore waters was derived from either: reaction of methane with sulphate and iron oxyhydroxides; and/or bacterially mediated oxidation of organic matter, precipitated during early diagenesis as authigenic carbonate cement with highly negative $\delta^{13} \mathrm{C}_{\text {carb }}$ values. The authigenic cement amplified the already light $\delta^{13} \mathrm{C}_{\text {carb }}$ signature preserved in the carbonate sand, resulting in the highly negative $\delta^{13} \mathrm{C}_{\text {carb }}$ values observed. Further supporting this argument is the contrast between $\delta^{13} \mathrm{C}_{\text {carb }}$ and $\delta^{13} \mathrm{C}_{\text {org }}$ values. 
There is a $10 \%$ shift in $\delta^{13} \mathrm{C}_{\text {org }}$ values through the Bitter Springs stage, from $-25 \%$ to $35 \%$ (Fig. 21), which is the same amplitude of change observed globally in the $\delta^{13} \mathrm{C}_{\text {carb }}$ values (values drop from $\sim+5 \%$ to $\sim-5 \%$ ), and therefore what one would expect to observe in the $\delta^{13} \mathrm{C}_{\text {org }}$ values as well if they are fractionated from global DIC. However, $\delta^{13} \mathrm{C}_{\text {carb }}$ values record a $24 \%$ shift ( +5 to -14 , Fig. 21 ) in the Amundsen Basin, supporting the interpretation that $\delta{ }^{13} \mathrm{C}_{\text {carb }}$ values record local basin effects, where authigenic carbonate is precipitated during early diagenesis.

\subsubsection{Euxinia and redox-sensitive trace metal enrichments in the Amundsen Basin}

Set in an intracontinental setting, the Amundsen Basin was intermittently restricted from the open ocean, notably during deposition of the Minto Inlet and Kilian formations (Fig. 1). There is physical evidence for restriction in the Upper Carbonate member of the Wynniatt Formation, implied by the preservation of lathe-shaped gypsum crystals, dolomite pseudomorphs of evaporative crusts, and the presence of a Mg-silicate (likely talc) mineral (Thomson et al., 2014). However, despite this evidence for restricted (evaporative) conditions, the overall depositional environment of the Upper Carbonate member of the Wynniatt Formation is interpreted as deep-water and below storm-wave base (Thomson et al., 2014). Strong evidence from Fe proxies for euxinic conditions is not surprising given the partially restricted setting; euxinia would have been favoured by water mass isolation, potentially promoting estuarine-style circulation.

The Mo, V, and U enrichments in the Upper Carbonate member of the Wynniatt Formation (Figs. 21 and 22) reflect paleoredox conditions in the Amundsen Basin as well 
as the global ocean redox state. As noted above, Mo, V, and U enrichments well above crustal levels also provide evidence for locally euxinic conditions. The magnitude of Mo enrichment in euxinic facies is controlled largely by the global extent of euxinic conditions (see Reinhard et al., 2013, and reference within). Therefore, Mo/TOC values comparable to or higher than those typical of the mid-Proterozoic rule out the possibility that there was more extensive euxinia during the pre-glacial Cryogenian compared to the rest of the Proterozoic; a scenario that was previously favoured based on Mo concentrations and isotope data from the roughly coeval ( $\sim 800$ - $750 \mathrm{Ma})$ rift deposits of the Chuar Group (Dahl et al., 2011; Reinhard et al., 2013), containing euxinic shales with lower Mo enrichments ( $<12 \mathrm{ppm})$. Indeed, our Mo/TOC ratios fall between mean values for the mid-Proterozoic and Phanerozoic, suggesting that the time interval leading up to the onset of widespread Neoproterozoic glaciations was a transitional period in Earth's redox evolution, during which oceans were likely less reducing than during the preceding billion years. The possibility that the large Mo enrichments have local rather than global significance and are due to basin restriction can be ruled out, as it is well established that basin restriction reduces Mo enrichment (Algeo and Lyons, 2006; Lyons et al., 2009). However, Mo drawdown in a restricted, isolated rift basin can explain the contrast between the Shaler Supergroup and the Chuar Group Mo records.

The $\mathrm{U}$ and $\mathrm{V}$ enrichments (Fig. 21) provide additional support for the idea that the pre-glacial Cryogenian represents a transitional period in Earth's redox evolution. Low U enrichments and U/TOC ratios relative to the Phanerozoic anoxic shale mean (Partin et al., 2013), but high V and V/TOC ratios relative to the Phanerozoic anoxic shale mean (Sahoo et al., 2012) are unusual. These elements respond similarly to anoxic marine 
conditions, but the modern marine residence and response times for $\mathrm{U}$ are much longer than for V (see mass balance modelling in Sahoo et al., 2012, and Partin et al., 2013). Therefore, we would expect that in a semi-restricted basin, like the Amundsen Basin, V reservoir drawdown would precede $\mathrm{U}$ drawdown, resulting in substantial $\mathrm{U}$ enrichment relative to $\mathrm{V}$ in anoxic shales, the opposite of what we observe in the Upper Carbonate member of the Wynniatt Formation. A potential explanation for these U-V enrichment trends may lie in the fact that suboxic marine sediments can be a source of $\mathrm{V}$ to oceans (Hastings et al., 1996). Suboxic sediments, for this case, are defined as those where oxygen is depleted in the uppermost $1 \mathrm{~cm}$ of the substrate and there is no surface solid phase Mn maximum. These sediments are likely be overlain by a weakly oxic water column. The $\mathrm{V}$ in these sediments is sourced from particulates, primarily metal oxides (see Hasting et al., 1996 for discussion). In a weakly oxidizing ocean, this could have lead to a global-scale build-up of the dissolved $\mathrm{V}$ reservoir, and thus the potential for large sedimentary $\mathrm{V}$ enrichment. Building from this framework, we propose that there may have been a shift in the pre-glacial Cryogenian to an ocean with an expansive, weakly oxic water column.

Persistently light $\delta^{34} S_{\text {pyrite }}$ values in the euxinic section of the Upper Carbonate member of the Wynniatt Formation suggest that the pre-glacial Cryogenian was marked by a growth in marine sulphate reservoir. Although there is a large dataset of sulphur isotope values for Proterozoic sedimentary pyrite (e.g. Canfield and Raiswell, 1999), euxinic shales do not typically show large ranges of $\Delta^{34} \mathrm{~S}$ values $\left(\Delta^{34} \mathrm{~S}<30 \%\right.$ ) prior to $635 \mathrm{Ma}$ (Sahoo et al., 2012; Scott et al., 2014). Scott et al. (2014) linked this shift in shale sulphur isotope systematics to growth of the marine sulphur reservoir. Thick sulphate 
evaporites in the Minto Inlet Formation and elsewhere globally, for example the Ten Stone Formation, Mackenzie Mountains (Turner and Long, 2012), and the Gillen Member of the Bitter Springs Formation, Amadeus Basin (Lindsay, 1987), occur immediately below sediments recording the Bitter Springs Stage, adding support to the notion that there was a significant seawater sulphate reservoir at that time (Prince, 2014). This is consistent with lower pyrite burial rates under generally more oxidizing conditions in the global ocean.

\subsection{Conclusions}

- A composite carbon isotope curve with paired $\delta^{13} \mathrm{C}_{\text {carb }}$ and $\delta^{13} \mathrm{C}_{\text {org }}$ values is presented for the upper Shaler Supergroup. $\delta^{13} \mathrm{C}_{\text {carb }}$ values range from -14.3 to $+7.7 \%$, with the average of $+3.0 \%$, while $\delta^{13} \mathrm{C}_{\text {org }}$ values range from -34.2 to $14.4 \%$, with the average of $-25.9 \%$.

- Basin-scale variations in $\delta^{13} \mathrm{C}_{\text {carb }}$ values for the upper Shaler Supergroup $(\sim 900-$ $720 \mathrm{Ma})$ make detailed chemostratigraphic correlation with stratigraphic sections in the northern Cordillera difficult. The Boot Inlet Formation may correlate with the lower Stone Knife/Silverberry formations of the Mackenzie Mountains Supergroup and the Gibben Formation of the Fifteenmile Group, supporting previous litho- and sequence stratigraphic correlations. Our data also supports previous correlations of the Kilian Formation with the Coates Lake Group, also considered correlative to the Callison Lake dolostone. The $\mathrm{C}$ isotope curve appears to be compressed in our study area when compared to those for the 
Fifteenmile Group and Mackenzie Mountains Supergroup, likely due to lower sedimentation rates in the Amundsen Basin.

- The Bitter Springs stage is present in the Wynniatt Formation of the Shaler Supergroup; however, $\delta^{13} \mathrm{C}$ values are much lighter than those described from coeval sedimentary successions. Therefore, these values require a local amplification, perhaps reflecting precipitation of isotopically light carbon in pore waters derived from reactions of methane and organic carbon with sulphate and ferric iron, resulting in precipitation of authigenic carbonate cement with highly negative $\delta^{13} \mathrm{C}_{\text {carb }}$ values.

- The majority of the studied interval includes sediments likely to have been deposited in oxic settings; however, redox proxies of a carbonaceous shale interval at the base of the Upper Carbonate member of the Wynniatt Formation indicate deposition under both euxinic and anoxic (ferruginous) conditions, with high concentrations of $\mathrm{Mo}, \mathrm{V}$, and $\mathrm{U}$. In these settings, Mo and $\mathrm{V}$ were sequestered and buried, but the global ocean must have been oxygenated before the Bitter Springs stage to allow for buildup of the large dissolved Mo and V reservoirs. This new data suggests that a shift to more oxygenated marine conditions preceded the oldest Cryogenian glaciation. 


\section{CHAPTER 5: CONCLUSIONS}

\subsection{Conclusions}

The main conclusions of this study are:

1. The Wynniatt Formation can be subdivided into four new members, which are recognized and described.

2. The Wynniatt Formation is interpreted to represent a succession of three highenergy, distally steepened carbonate ramps. Sedimentation was predominantly controlled by storm-generated processes, with minor reworking by wave and tidal currents. Isopach maps provide support that the Wynniatt Formation accumulated in a circular basin. Inferred changes in the position of regional depocentres are associated with each stage of ramp development.

3. Five unconformity-bounded, transgressive-regressive (T-R) cycles are recognized through a succession that includes, in ascending stratigraphic order, the Jago Bay, Minto Inlet, and Wynniatt formations. T-R cycles are difficult to correlate regionally because accommodation was affected by local tectonically controlled subsidence (e.g. Fifteenmile basin). The exception is sequence S7 from the Fifteenmile Group and the coeval T-R5 defined here from the Shaler Supergroup, which reflects a significant regional basin-deepening event that may relate to the onset of a global marine transgression. 
4. The upper Shaler Supergroup (Boot Inlet to Kilian formations) and Little Dal Group (Mackenzie Mountains Supergroup) are correlative with the Fifteenmile Group in its entirety.

5. Three tectonostratigraphic units are recognized in the upper Shaler Supergroup. Stage 1 records subsidence of a sag basin, Stage 2 preserves evidence of syndepositional faulting and thermal doming, and Stage 3 represents the rifting phase that concluded with extrusion of a thick succession of continental flood basalts.

6. Subsidence during deposition of the middle to upper Shaler Supergroup in the Amundsen Basin may have been influenced by lithospheric stretching and thinning, if northwest Laurentia had passed over a mantle plume at $830 \mathrm{Ma}$, or by intra-plate stresses related to some other cause of extension, which formed faultbound rift basins in the Mackenzie Mountains and Fifteenmile basins. Inferred changes in subsidence patterns in the Amundsen Basin are likely the result of farfield extensional stresses, which were related to more pronounced extension that manifested as fault-related sedimentation in coeval basins located closer to the paleomargin of Laurentia.

7. $\delta{ }^{13} \mathrm{C}_{\text {carb }}$ and $\delta{ }^{13} \mathrm{C}_{\text {org }}$ composite secular curves for the upper Shaler Supergroup $(\sim 900-720 \mathrm{Ma})$ are presented. Detailed chemostratigraphic correlation with adjacent successions is tenuous, complicated by lower sedimentation rates in the Amundsen Basin, resulting in condensation of the $\mathrm{C}$ isotope curve.

8. The global Bitter Springs stage negative $\delta{ }^{13} \mathrm{C}$ anomaly is recorded in the Wynniatt Formation; however, $\delta 13 \mathrm{C}$ values are much lighter than those 
measured from coeval sedimentary successions. The more negative values in the Wynniatt Formation are interpreted to reflect precipitation of isotopically light carbon in pore waters derived from reaction of methane and organic carbon with sulphate and ferric Fe. This resulted in precipitation of authigenic carbonate cement with highly negative $\delta{ }^{13} \mathrm{C}_{\text {carb }}$ values, locally amplifying negative values.

9. The majority of the upper Shaler Supergroup includes sediments likely to have been deposited in oxic settings; however, redox proxies in the Upper Carbonate member of the Wynniatt Formation indicate deposition under both euxinic and anoxic (ferruginous) conditions, with high concentrations of Mo, V, and $\mathrm{U}$. The global ocean must have been oxygenated in phase with the Bitter Springs stage to allow for build-up of the large dissolved Mo and V reservoirs, suggesting there was a shift to more oxygenated marine conditions in the interval preceding the oldest Cryogenian glaciation.

\subsection{Future Research}

There are many questions that could still be addressed, including:

- Characterization of sequence or T-R stratigraphy of the correlative Little Dal Group in the Mackenzie Mountains, to see if sequences there can be correlated with the ones defined in this study.

- If subsidence in the upper Shaler Supergroup is related to lithospheric thinning signaling the onset of Rodinia breakup, what are the subsidence 
mechanisms that created accommodation for deposition of the lower Shaler Supergroup?

- Additional C-isotope study of the turbidite layers within the shale that preserves the negative carbon excursion in the Upper Carbonate member of the Wynniatt Formation. This study predicts that the isotopic values of the cement compared to the allochems would be significantly different.

- Further micropaleontological studies are suggested. There are other known localities of scale and vase-shaped microfossils in successions of the same age globally, however the previous study of microfossils from the Shaler Supergroup was limited to the uppermost Black Shale member. This study predicts that there is good potential for diversification of life at this time, if it is linked to oxygenation of the oceans, as is observed here. 


\section{REFERENCES}

Aitken, J.D., 1981. Stratigraphy and sedimentology of the upper Proterozoic Little Dal Group, Mackenzie Mountains, Northwest Territories. In: F.H.A. Campbell (Ed.), Proterozoic basins of Canada. Geological Survey of Canada, Paper 81-10, pp. 47-71.

Aitken, J.D., Long, D.G.F., 1978. Mackenzie tectonic arc - Reflection of early basin configuration? Geology, 6: 626-629.

Aitken, J.D., Long, D.G.F., Semikhatov, M.A., 1978. Progress in Helikian stratigraphy, Mackenzie Mountains. Geological Survey of Canada Current Research 78-1A, 481-484.

Aitken, J.D., Pugh, D.C., 1984. The Fort Norman and Leith Ridge structures: Major, buried Precambrian features underlying Franklin Mountains and Great Bear and Mackenzie Plains. Bulletin of Canadian Petroleum Geology, 32: 139-146.

Algeo, T.J., Lyons, T.W., 2006. Mo - total organic carbon covariation in modern anoxic marine environments: Implications for analysis of paleoredox and paleohydrographic conditions. Paleoceanography 2, 1-23.

Allen, P.A., Allen, J.R., 2005. Basin analysis: Principles and applications. Blackwell, Oxford.

Allen, P. A., and Armitage, J. J., 2012, Cratonic basins, in Busby, C., and Azor, A., eds., Tectonics of sedimentary basins: Recent advances, Blackwell Publishing Ltd., p. 602620.

Anbar, A., Duan, Y., Lyons, T.W., Arnold, G.L., Kendall, B., Creaser, R.A., Kaufman, A.J., Gordan, G.W., Scott, C., Garvin, J., Buick, R., 2007. A whiff of oxygen before the Great Oxidation Event? Science 317.

Asmerom, Y., Jacobsen, S.B., Knoll, A.H., Butterfield, N.J., Swett, K., 1991. Strontium isotope variations of Neoproterozoic seawater: Implications for crustal evolution. Geochemica et Cosmochimica Acta 55, 2883-2894.

Aspler, L.B., Pilkington, M., and Miles, W.F., 2003, Interpretations of Precambrian basement based on recent aeromagnetic data, Mackenzie Valley: Geological Survey of Canada, Current Research 2003-C2, p. 1-11. 
Balazs, R.J., Klein, G., 1972. Roundess-mineralogical relations of some intertidal sands. Journal of Sedimentary Petrology, 42(2): 425-433

Batten, K.L., Narbonne, G.M., James, N.P., 2004. Paleoenvironments and growth of early Neoproterozoic calcimicrobial reefs: platformal Little Dal Group, northwestern Canada. Precambrian Research, 133: 249-269.

Bekker, A., Holland, H.D., Wang, P., Rumble, D., Stein, H.J., Hannah, J.L., Coetzee, L.L., Beukes, N.J., 2004. Dating the rise of atmospheric oxygen. Nature 427, 117-120

Bell, R.T., Jefferson, C.W., 1987. An hypothesis for an Australian-Canadian connection in the late Proterozoic and the birth of the Pacific Ocean. In: E. Brennan (Ed.), Pacific Rim Congress 87; an international congress on the geology, structure, mineralisation and economics of the Pacific Rim, Gold Coast, Queensland, Australia, pp. 39-50.

Bertrand-Sarfati, J., Moussine-Pouchkine, A., 1985. Evolution and environmental conditions of Conophyton-Jacutophyton associations in the Atar Dolomite (Upper Proterozoic, Mauritania). Precambrian Research, 29: 207-234

Bjerrum, C.J., Canfield, D., 2011. Towards a quantitative understanding of the late Neoproterozoic carbon cycle. Proceedings of the National Academy of Sciences 108, 5542-5547.

Borg, S. G., and DePaulo, D. J., 1994, Laurentia, Australia, and Antarctica as a Late Proterozoic supercontinent: Constraints from isotopic mapping: Geology, v. 22, p. 307310.

Brasier, M.D., Shields, G., 2000. Neoproterozoic chemostratigraphy and correlation of the Port Askaig glaciation, Dalradian Supergroup of Scotland. Journal of the Geological Society, London 157, 909-914.

Bristow, T.F., Kennedy, M.J., 2008. Carbon isotope excursions and the oxidant budget of the Ediacaran atmosphere and ocean. Geology 36, 863-866.

Brookfield, M. E., 1993, Neoproterozoic Laurentia-Australia fit: Geology, v. 21, p. 683686.

Bull, S., Selley, D., Broughton, D., Hitzman, M., Cailteux, J., Large, R., McGoldrick, P., 2011. Sequence and carbon isotopic stratigraphy of the Neoproterozoic Roan Group strata of the Zambian copperbelt. Precambrian Research 190, 70-89.

Burchette, T.P., Wright, V.P., 1992. Carbonate ramp depositional systems. Sedimentary Geology, 79: 3-57. 
Burrett, C., and Berry, R., 2000, Proterozoic Australia-Western United States (AUSWUS) fit between Laurentia and Australia: Geology, v. 28, no. 2, p. 103-106.

Butterfield, N.J., 2005. Reconstructing a complex early Neoproterozoic eukaryote, Wynniatt Formation, arctic Canada. Lethaia, 38: 155-169.

Butterfield, N.J., Rainbird, R.H., 1998. Diverse organic-walled fossils, including "possible dinoflagellates" from the early Neoproterozoic of arctic Canada. Geology, 26(11): 963-966.

Canfield, D., Poulton, S.W., Knoll, A.H., Narbonne, G.M., Ross, G.M., Goldberd, T., Strauss, H., 2008. Ferruginous conditions dominated later Neoproterozoic deep-water chemistry. Science 321, 949-952.

Canfield, D., Poulton, S.W., Narbonne, G.M., 2007. Late-Neoproterozoic deepoxygenation and the rise of animal life. Science 315, 92-95.

Canfield, D., Raiswell, R., 1999. The evolution of the sulfur cycle. American Journal of Science 299, 697-723.

Canfield, D., Raiswell, R., Westrich, J.T., Reaves, C.M., Berner, R.A., 1986. The use of chromium reduction in the analysis of reduced inorganic sulfur in sediments and shales. Chemical Geology 54, 149-155.

Canfield, D., Teske, A., 1996. Late Proterozoic rise in atmospheric oxygen concentration inferred from phylogenetic and sulphur-isotope studies. Nature 382, 127-132.

Clough, J.G., Goldhammer, R.K., 2000. Evolution of the Neoproterozoic Katakturuk dolomite ramp complex, NE Brooks Ranges, Alaska. In: J.P. Grotzinger, N.P. James (Eds.), Carbonate sedimentation and diagenesis in the evolving Precambrian world. Society for Sedimentary Geology, pp. 209-241.

Cook, H.E., Mullins, H.T., 1983. Basin margin environment. In: P.A. Scholle, D.G. Bebout, C.H. Moore (Eds.), Carbonate depositional environments. The American Association of Petroleum Geologists, Tulsa, pp. 539-617.

Coplen, T.B., Brand, W.A., Gehre, M., Groning, M., Meijer, H.A.J., Toman, B., Verkouteren, R.M., 2006. New guidelines for delta13C measurements. Analytical Chemistry 78 .

Dahl, T.W., Canfield, D., Rosing, M.T., Frei, R.E., Gordan, G.W., Knoll, A.H., Anbar, A., 2011. Molybdenum evidence for expansive sulfidic water masses in 750 Ma oceans. Earth and Planetary Science Letters 311, 264-274.

Dalziel, I. W. D., 1997, Neoproterozoic-Paleozoic geography and tectonics: Review, hypothesis, environmental speculation: GSA Bulletin, v. 109, no. 1, p. 16-42. 
Davidson, A., 2008, Late Paleoproterozoic to mid-Neoproterozoic history of northern Laurentia: An overview of central Rodinia: Precambrian Research, v. 160, p. 5-22.

Derry, L.A., 2010a. A burial diagenesis origin for the Ediacaran Shuram-Wonoka carbon isotope anomaly. Earth and Planetary Science Letters 294, 152-162.

Derry, L.A., 2010b. On the significance of delta13C correlations in ancient sediments. Earth and Planetary Science Letters 296, 497-501.

Des Marais, D.J., Strauss, H., Summons, R.E., Hayes, J.M., 1992. Carbon isotope evidence for the stepwise oxidation of the Proterozoic environment. Nature 359, 605-609.

Dickens, G.R., 2003. Rethinking the global carbon cycle with a large, dynamic and microbially mediated gas hydrate capacitator. Earth and Planetary Science Letters 213, 169-183.

Dickens, G.R., Castillo, M.M., Walker, J.C.G., 1997. A blast of gas in the latest Paleocene: Simulating first-order effects of massive dissociation of oceanic methane hydrate. Geology 25, 259-262.

Dumas, S., Arnott, R.W.C., Southard, J.B., 2005. Experiments on oscillatory-flow and combined-flow bed forms: Implications for interpreting parts of the shallow-marine sedimentary record. Journal of Sedimentary Research, 75(3): 501-513.

Eisbacher, G. H., 1985, Late Proterozoic rifting, glacial sedimentation, and sedimentary cycles in the light of Windermere deposition, western Canada: Palaeogeography, Palaeoclimatology, Palaeoecology, v. 51, p. 231-254.

Emerson, S.R., Huested, S.S., 1991. Ocean anoxia and the concentations of molybdenum and vanadium in seawater. Marine Chemistry 34, 177-196.

Embry, A. F., 1993, Transgressive - regressive (T-R) sequence analysis of the Jurassic succession of the Sverdrup Basin, Canadian Arctic Archipelago: Canadian Journal of Earth Sciences, v. 30, p. 301-320.

Embry, A. F., 2009, Practical sequence stratigraphy: Canadian Society of Petroleum Geologists, v. online at www.cspg.org, p. 79.

Evans, D., 2009. The palaeomagnetically viable, long-lived and all-inclusive Rodinia supercontinent reconstruction. Geological Society, London, Special Publications, 327: 371-404.

Fike, D.A., Grotzinger, J.P., Pratt, L.M., Summons, R.E., 2006. Oxidation of the Ediacaran Ocean. Nature Letters 444, 744-747. 
Fry, B., Silva, S.R., Kendall, C., Anderson, R.K., 2002. Oxygen isotope corrections for online delta34S analyses. Rapid Communications in Mass Spectrometry 16, 854-858.

Furniss, G., Rittel, J.F., Winston, D., 1998. Gas bubble and expansion crack origin of "molar-tooth" calcite structures in the middle Proterozoic Belt Supergroup, western Montana. Journal of Sedimentary Research, 68(1): 104-114.

Gill, B.C., Lyons, T.W., Young, S.A., Kump, L.R., Knoll, A.H., Saltzman, M.R., 2011. Geochemical evidence for widespread euxinia in the Later Cambrian ocean. Nature Letters $469,80-83$.

Gower, C. F., and Krogh, T. E., 2002, A U-Pb geochronological review of the Proterozoic history of the eastern Grenville Province: Canadian Journal of Earth Sciences, v. 39, p. 795-829.

Halverson, G. P., 2006, A Neoproterozoic chronology, in Xiao, S., and Kaufman, A. J., eds., Neoproterozoic geobiology and paleobiology, Springer, p. 231-271.

Halverson, G.P., Hoffman, P.F., Schrag, D.P., Maloof, A.C., Rice, A.H.N., 2005. Toward a Neoproterozoic composite carbon-isotope record. Bulletin of the Geological Society of America, 117: 1181-1207.

Halverson, G.P., Maloof, A.C., Schrag, D.P., Dudas, F.O., and Hurtgen, M.T., 2007a, Stratigraphy and geochemistry of a ca 800 Ma negative carbon isotope interval in northeastern Svalbard: Chemical Geology, v. 237, p. 5-27.

Halverson, G.P., Dudas, F.O., Maloof, A.C., Bowring, S.A., 2007b. Evolution of the $87 \mathrm{Sr} / 86 \mathrm{Sr}$ composition of Neoproterozoic seawater. Palaeogeography, Palaeoclimatology, Palaeoecology 256, 103-129.

Halverson, G.P., Wade, B.P., Hurtgen, M.T., and Barovich, K.M., 2010, Neoproterozoic chemostratigraphy: Precambrian Research, v. 182, p. 337-350.

Halverson, G. P., Macdonald, F. A., Strauss, J. V., Smith, E. F., Cox, G. M., and HubertTheou, L., 2012, Updated definition and correlation of the lower Fifteenmile Group in the central and eastern Ogilvie Mountains, in MacFarlane, K. E., and Sack, P. J., eds., Yukon Exploration and Geology 2011, Yukon Geological Survey, p. 75-90.

Harlan, S.S., Heaman, L.M., LeCheminant, A.N., Premo, W.R., 2003. Gunbarrel mafic magmatic event: A key 780 Ma time marker for Rodinia plate reconstructions. Geology, 31(12): 1053-1056.

Hastings, D.W., Emerson, S.R., Mix, A.C., 1996. Vanadium in foraminiferal calcite as a tracer for changes in the areal extent of reducing sediments. Paleoceanography 11, 665678. 
Hayes, J.M., Strauss, H., Kaufman, A.J., 1999. The abundance of 13C in marine organic matter and isotopic fractionation in the global biogeochemical cycle of carbon during the past $800 \mathrm{Ma}$. Chemical Geology 161, 103-125.

Heaman, L.M., LeCheminant, A.N., Rainbird, R.H., 1992. Nature and timing of Franklin igneous events, Canada: Implications for a Late Proterozoic mantle plume and the breakup of Laurentia. Earth and Planetary Science Letters, 109: 117-131.

Hetzel, A., Bottcher, M.E., Wortmann, U.G., Brumsack, H.-J., 2009. Paleo-redox conditions during OAE 2 reflected in Demerara Rise sediment geochemistry (ODP Leg 207). Palaeogeography, Palaeoclimatology, Palaeoecology 273, 302-328.

Hill, A.C., Cotter, K.L., Grey, K., 2000. Mid-Neoproterozoic biostratigraphy and isotope stratigraphy in Australia. Precambrian Research, 100: 281-298.

Hill, A.C., and Walter, M.R., 2000, Mid-Neoproterozoic ( 830-750 Ma) isotope stratigraphy of Australia and global correlation: Precambrian Research, v. 100, p. 181211.

Hoffman, P., 1976. Environmental diversity of middle Precambrian stromatolites. In: M.R. Walter (Ed.), Stromatolites. Elsevier pp. 599-611.

Hoffman, P. F., 1991, Did the breakout of Laurentia turn Gondwanaland inside-out?: Science, v. 252, p. 1409-1411.

Hofmann, H.J., 1985, The Mid-Proterozoic Little Dal Microbiota, Mackenzie Mountains, Northwest Canada: Palaeontology, v. 28, p. 331-354.

Hofmann, H.J., Aitken, J.D., 1979. Precambrian biota from the Little Dal Group, Mackenzie Mountains, northwestern Canada. Canadian Journal of Earth Sciences, 16: 150-166.

Hofmann, H.J., Rainbird, R.H., 1995. Carbonaceous megafossils from the Neoproterozoic Shaler Supergroup of Arctic Canada. Palaeontology, 37(4): 721-731.

Holland, H.D., 1984. The chemical evolution of the atmosphere and oceans. Princeton University Press.

Howell, P.D., van der Pluijm, B.A., 1990. Early history of the Michigan basin:

Subsidence and Appalachian tectonics. Geology, 18: 1195-1198.

Hynes, A., and Rivers, T., 2010, Protracted continental collision - evidence from the Grenville Orogen: Canadian Journal of Earth Sciences, v. 47, p. 591-620.

Irwin, H., Curtis, C., Coleman, M., 1977. Isotopic evidence for source of diagenetic carbonates formed during burial of organic-rich sediments. Nature 269. 
James, N.P., Narbonne, G.M., Sherman, A.G., 1998. Molar-tooth carbonates: Shallow subtidal facies of the Mid- to Late Proterozoic. Journal of Sedimentary Research, 68(5): 716-722.

James, N.P., Kendall, A.C., and Pufahl, P.K., 2010, Introduction to Biological and Chemical Sedimentary Facies Models, in James, N.P., and Dalrymple, R.W., eds., Facies Models 4, Geological Association of Canada, p. 323-340.

Jiang, G., Kaufman, A.J., Christie-Blick, N., Zhang, S., Wu, H., 2007. Carbon isotope variability across the Ediacaran Yangtze platform in South China: Implications for a large surface-to-deep ocean delta (super 13) C gradient. Earth and Planetary Science Letters 261, 303-320.

Jiang, G., Kennedy, M.J., Christie-Blick, N., 2003. Stable isotopic evidence for methane seeps in Neoproterozoic postglacial cap carbonates. Letters to Nature 426, 822-825.

Jiang, G., Wang, X., Shi, X., Xiao, S., Zhang, S., Dong, J., 2012. The origin of decoupled carbonate and organic carbon isotope signatures in the early Cambrian (ca. 542-540 Ma) Yangtze platform. Earth and Planetary Science Letters 317-318, 96-110.

Johnson, J.G., Klapper, G., Sandberg, C.A., 1985. Devonian eustatic fluctuations in Euramerica. Geological Society of America Bulletin, 96: 567-587.

Johnston, D.T., Poulton, S.W., Dehler, C., Porter, S., Husson, J., Canfield, D., Knoll, A.H., 2010. An emerging picture of Neoproterozoic ocean chemistry: Insights from the Chuar Group, Grand Canyon, USA. Earth and Planetary Science Letters 290, 64-73.

Jones, D.S., Maloof, A.C., Hurtgen, M.T., Rainbird, R.H., Schrag, D.P., 2010. Regional and global chemostratigraphic correlation of the Early Neoproterozoic Shaler Supergroup, Victoria Island, Northwestern Canada. Precambrian Research, 181: 43-63.

Kah, L.C., Bartley, J.K., Stagner, A.F., 2009. Reinterpreting a Proterozoic enigma: Conophyton-Jacutophyton stromatolites of the Mesoproterozoic Atar Group, Mauritania. In: P.K. Swart, G. Eberli, J.A. McKenzie (Eds.), Perspectives in carbonate geology: A tribute to the career of Robert Nathan Ginsberg Wiley-Blackwell.

Kaufman, A.J., Corsetti, F.A., Varni, M.A., 2007. The effect of rising atmospheric oxygen on carbon and sulfur isotope anomalies in the Neoproterozoic Johnnie Formation, Death Valley, USA. Chemical Geology 237, 47-63.

Kendall, A. C., 2010, Marine Evaporites, in James, N. P., and Dalrymple, R. W., eds., Facies Models 4: St. John's, Geological Association of Canada, p. 505-540. 
Kendall, B., Creaser, R. A., and Selby, D., 2006, Re-Os geochronology of postglacial black shales in Australia: Constraints on the timing of "Sturtian" glaciation: Geology, v. 34, no. 9, p. 729-732.

Kirschivink, J. L., 1992, Late Proterozoic low-latitude global glaciation: the Snowball Earth in Schopf, J. W., and Klein, C., eds., The Proterozoic Biosphere: A Multidisciplinary Study, Cambridge University Press.

Knauth, L.P., Kennedy, M.J., 2009. The late Precambrian greening of the Earth. Nature Letters $460,728-732$.

Knoll, A.H., Hayes, J.M., Kaufman, A.J., Swett, K., Lambert, I.B., 1986. Secular variation in carbon isotope ratios from Upper Proterozoic successions of Svalbard and East Greenland. Nature 321, 832-838.

Krapez, B., 1997, Sequence-stratigraphic concepts applied to the indentification of depositional basins and global tectonic cycles: Australian Journal of Earth Sciences, v. 44, no. 1, p. 1-36.

Kump, L.R., Junium, C., Arthur, M.A., Brasier, A., Fallick, A., Melezhik, V., Lepland, A., Crne, A.E., Luo, G., 2011. Isotopic evidence for massive oxidation of organic matter following the Great Oxidation Event. Science 334, 1694-1696.

Kvenvolden, K.A., 1993. Gas hydrates - geological perspective and global change. Reviews of Geophysics 31, 173-187.

Lafond, G., 2011. Understanding the redox state of Neoproterozoic oceans: a geochemical study of shales from the second member of the Wynniatt Formation, Minto Inlier, Northwest Territories, Canada, Department of Geological Sciences. University of Manitoba, Winnipeg, pp. 1-139.

Leavitt, W.D., Halevy, I., Bradley, A.S., Johnston, D.T., 2013. Influence of sulfate reduction rates on the Phanerozoic sulfur isotope record. Proceedings of the National Academy of Sciences, 1-6.

Li, Z.X., Evans, D.A.D., 2011. Late Neoproterozoic 40 degree intraplate rotation within Australia allows for a tighter-fitting and longer-lasting Rodinia. Geology, 39(1): 39-42.

Li, Z.X., Bogdanova, S.V., Collins, A.S., Davidson, A., De Waele, B., Ernst, R.E., Fitzsimons, I.C.W., Fuck, R.A., Gladkochub, D.P., Jacobs, J., Karlstrom, K.E., Lu, S., Natapov, L.M., Pease, V., Pisarevsky, S.A., Thrane, K., and Vernikovsky, V. 2008. Assembly, configuration, and break-up history of Rodinia: A synthesis. Precambrian Research, 160: 179-210. 
Li, Z. X., Li, X. H., Kinny, P. D., and Wang, J., 1999, The breakup of Rodinia: did it start with a mantle plume beneath South China?: Earth and Planetary Science Letters, v. 173, p. 171-181.

Li, Z. X., Zhang, L., and Powell, C. M., 1995, South china in Rodinia: part of the missing link between Australia-East Antarctica and Laurentia?: Geology, v. 23, p. 407-410.

Lindsay, J.F., 1987. Upper Proterozoic evaporites in the Amadeus basin, central Australia, and their role in basin tectonics. Geological Society of America Bulletin 99, 852-865.

Lindsay, J. F., Kennard, J. M., and Southgate, P. N., 1993, Applications of sequence stratigraphy in an intracratonic setting, Amadeus Basin, central Australia, in Posamentier, H. W., Summerhayes, C. P., Haq, B. U., and Allen, G. P., eds., Sequence Stratigraphy and Facies Associations: Special Publication Number 18 of the International Association of Sedimentologists, Blackwell Scientific Publications.

Lloyd, R.M., Perkins, R.D., Kerr, S.D., 1987. Beach and shoreface ooid deposition on shallow interior banks, Turks and Caicos Islands, British West Indies. Journal of Sedimentary Petrology, 57(6): 976-982.

Logan, B.W., Rezak, R., Ginsburg, R.N., 1964. Classification and environmental significance of algal stromatolites. The Journal of Geology, 72(1): 68-83.

Logan, B.W., Hoffman, P., Gebelein, C.D., 1974. Algal mats, cryptalgal fabrics, and structures, Hamelin Pool, Western Australia. American Association of Petroleum Geologists, 22: 140-194.

Long, D.G.F., Rainbird, R.H., Turner, E.C., MacNaughton, R.B., 2008. Early Neoproterozoic strata (Sequence B) of mainland northern Canada and Victoria and Banks islands: a contribution to the Geological Atlas of the Northern Canadian Mainland Sedimentary Basin. Geological Survey of Canada, Open File 5700: 1-24.

Loyd, S.J., Marenco, P.J., Hagadorn, J.W., Lyons, T.W., Kaufman, A.J., Sour-Tovar, F., Corsetti, F.A., 2012. Sustained low marine sulfate concentrations from the Neoproterozoic to the Cambrian: Insights from carbonates of northwestern Mexico and eastern California. Earth and Planetary Science Letters 339-340, 79-94.

Lyons, T.W., 1997. Sulfur isotopic trends and pathways of iron sulfide formation in upper Holocene sediments of the anoxic Black Sea. Geochemica et Cosmochimica Acta 61, 3367-3382.

Lyons, T.W., Anbar, A., Severmann, S., Scott, C., Gill, B.C., 2009. Tracking euxinia in the ancient ocean: A multi-proxy perspective and Proterozoic case study. Annual Review of Earth and Planetary Sciences 37, 507-534. 
Macdonald, F.A., Schmitz, M.D., Crowley, J.L., Roots, C.F., Jones, D.S., Maloof, A.C., Strauss, J.V., Cohen, P.A., Johnston, D.T., and Schrag, D.P. 2010. Calibrating the Cryogenian. Science, 327: 1241-1243.

Macdonald, F.A., Halverson, G.P., Strauss, J.V., Smith, E.F., Cox, G.M., Sperling, E.A., and Roots, C.F. 2012. Early Neoproterozoic basin formation in Yukon, Canada: Implications for the make-up and break-up of Rodinia. Geoscience Canada, 39: 77-99.

Marshall, D., Anglin, C.D., 2004. CO2-clathrate destabilization: a new model of formation for molar tooth structures. Precambrian Research, 129: 325-341.

Maloof, A.C., Halverson, G.P., Kirschivink, J.L., Schrag, D.P., Weiss, B.P., Hoffman, P., 2006. Combined paleomagnetic, isotopic, and stratigraphic evidence for true polar wander from the Neoproterozoic Akademikerbreen Group, Svalbard, Norway. GSA Bulletin 118, 1099-1124.

McFadden, K.A., Huang, J., Chu, X., Jiang, G., Kaufman, A.J., Zhou, C., Yuan, X., Xiao, S., 2008. Pulsed oxidation and biological evolution in the Ediacaran Doushantuo Formation. Proceedings of the National Academy of Sciences 105, 3197-3202.

Moores, E. M., 1991, Southwest U.S.-East Antarctic (SWEAT) connection: A hypothesis: Geology v. 19, p. 425-428.

Morin, J., Rainbird, R.H., 1993. Sedimentology and sequence stratigraphy of the Neoproterozoic Reynolds Point Formation, Minto Inlier, Victoria Island, N.W.T. Current Research, Part C: Geological Survey of Canada Paper 93-1C: 7-18.

Morris, S. C., 1993, The fossil record and the early evolution of the Metazoa: Nature Review Article, v. 361, no. 219-225.

Narbonne, G.M., James, N.P., Rainbird, R.H., Morin, J., 2000. Early Neoproterozoic (Tonian) patch reef complexes, Victoria Island, Arctic Canada. In: J.P. Grotzinger, N.P. James (Eds.), Carbonate sedimentation and diagenesis in the evolving Precambrian world. Society for Sedimentary Geology, pp. 163-177.

Partin, C.A., Bekker, A., Planavsky, N., Scott, C., Gill, B.C., Li, C., Podkovyrov, V., Maslov, A., Konhauser, K.O., Lalonde, S.V., Love, G.D., Poulton, S.W., Lyons, T.W., 2013. Large-scale fluctuations in Precambrian atmospheric and oceanic oxygen levels from the record of U in shales. Earth and Planetary Science Letters 369-370, 284-293.

Pinet, N., Lavoie, D., Dietrich, J., Hu, K., and Keating, P., 2013, Architecture and subsidence history of the intracratonic Hudson Bay Basin, northern Canada: EarthScience Reviews, v. 125, p. 1-23. 
Planavsky, N., Grey, K., 2008. Stromatolite branching in the Neoproterozoic of the Centralian Superbasin, Australia: and investigation into sedimentary and microbial control of stromatolite morphology. Geobiology, 6: 33-45.

Poulton, S.W., Canfield, D., 2005. Development of a sequential extraction procedure for iron: Implications for iron partitioning in continentally derived particulates. Chemical Geology 214, 209-221.

Poulton, S.W., Canfield, D., 2011. Ferruginous conditions: a dominant feature of the ocean through Earth's history. Elements 7, 107-112.

Poulton, S.W., Raiswell, R., 2002. The low-temperature geochemical cycle of iron: from continental fluxes to marine sediment deposition. American Journal of Science 302, 774805.

Pratt, B.R., 1998. Molar-tooth structure in Proterozoic carbonate rocks: Origin from synsedimentary earthquakes, and implications for the nature and evolution of basins and marine sediment. GSA Bulletin, 110(8): 1028-1045.

Pratt, B.R., 2010. Peritidal carbonates. In: N.P. James, R.W. Dalrymple (Eds.), Facies Models 4. Geological Association of Canada, St. John's, pp. 401-420.

Prave, A.R., Fallick, A., Thomas, C.W., Graham, C.M., 2009. A composite C-isotope profile for the Neoproterozoic Dalradian Supergroup of Scotland and Ireland. Journal of the Geological Society, London 166, 845-857.

Prince, J. K. G., 2014, Sequence stratigraphic, lithostratigraphic, and stable isotope analysis of the Minto Inlet Formation and Kilian Formation, of the Shaler Supergroup, Northwest Territories M.Sc.: Carleton University, 139 p.

Rainbird, R. H., 1993, The sedimentary record of mantle plume uplift preceeding eruption of the Neoproterozoic Natkusiak flood basalt: Journal of Geology, v. 101, p. 305-318.

Rainbird, R.H., Heaman, L.M., Young, G.M., 1992. Sampling Laurentia: Detrital zircon geochronology offers evidence for an extensie Neoproterozoic river system originating from the Grenville orogen. Geology, 20: 351-354.

Rainbird, R.H., Jefferson, C.W., Hildebrand, R.S., Worth, J.K., 1994. The Shaler Supergroup and revision of Neoproterozoic stratigraphy in Amundsen Basin, Northwest Territories. Geological Survey of Canada, Current Research, Part C, Paper 92-01C: 6170.

Rainbird, R.H., Jefferson, C.W., Young, G.M., 1996. The early Neoproterozoic sedimentary Succession B of northwestern Laurentia: Correlations and paleogeographic significance. GSA Bulletin, 108(4): 454-470. 
Rainbird, R.H., McNicoll, V.J., Theriault, L.M., Abbott, J.G., Long, D.G.F., and Thorkelson, D.J., 1997. Pan-continental river system draining Grenville Oroogen recorded by $\mathrm{U}-\mathrm{Pb}$ and $\mathrm{Sm}-\mathrm{Nd}$ geochronology of Neoproterozoic quartzarenites and mudrocks, Northwestern Canada. Journal of Geology, 105: 1-17.

Rainbird, R.H., Stern, R.A., Khudoley, A.K., Kropachev, A.P., Heaman, L.M., and Sukhorukov, V.I., 1998. U-Pb geochronology of Riphean sandstone and gabbro from southeast Siberia and its bearing on the Laurentia-Siberia connection. Earth and Planetary Science Letters, 164: 409-420.

Rainbird, R. H., Krapez, B., Thomson, D., and Prince, J., 2012, Amundsen Basin of northern Canada with comparison to the Amadeus Basin of central Australia; remnants of supercontinent Rodinia's epeiric sea, 34th International Geological Congress: Brisbane, Australia.

Rainbird, R.H., Bedard, J.H., Dewing, K., Hadlari, T., Thomson, D., 2013. Geology, Qiqittiivik, Victoria Island, Northwest Territories. Geological Survey of Canada, Canadian Geosciences Map 59, 1 sheet.

Raiswell, R., Canfield, D., 1998. Sources of iron for pyrite formation in marine sediments. American Journal of Science 298, 219-245.

Rayner, N., Rainbird, R.H., 2013. U-Pb geochronology of the Shaler Supergroup, Victoria Island, northwest Canada: 2009-2013. Geological Survey of Canada: Open File 7419: 1-62.

Reineck, H.-E., Wunderlich, F., 1968. Classification and origin of flaser and lenticular bedding. Sedimentology, 11: 99-104.

Reinhard, C.T., Planavsky, N., Robbins, L.J., Partin, C.A., Gill, B.C., Lalonde, S.V., Bekker, A., Konhauser, K.O., Lyons, T.W., 2013. Proterozoic ocean redox and biogeochemical stasis. Proceedings of the National Academy of Sciences, 1-9.

Reinhard, C.T., Raiswell, R., Scott, C., Anbar, A., Lyons, T.W., 2009. A Late Archean sulfidic sea stimulated by early oxidative weathering of the continents. Science 326, 713716.

Ross, G. M., 1991, Tectonic setting of the Windermere Supergroup revisited: Geology, v. 19 , p. $1125-1128$.

Rothman, D.A., Hayes, J.M., Summons, R.E., 2003. Dynamics of the Neoproterozoic carbon cycle. Proceedings of the National Academy of Sciences 100, 8124-8129. 
Sahoo, S.K., Planavsky, N., Kendall, B., Wang, X., Shi, X., Scott, C., Anbar, A., Lyons, T.W., Jiang, G., 2012. Ocean oxygenation in the wake of the Marinoan glaciation. Nature Letters 489.

Sansjofre, P., Ader, M., Trindade, R.I.F., Elie, M., Lyons, J., Cartigny, P., Nogueira, A.C.R., 2011. A carbon isotope challenge to the snowball Earth. Nature Letters 478, 9397.

Scholz, F., Severmann, S., McManus, J., Hensen, C., 2014. Beyond the Black Sea paradigm: The sedimentary fingerprint of an open-marine iron shuttle. Geochemica et Cosmochimica Acta 127, 368-380.

Schrag, D.P., Higgins, J.A., Macdonald, F.A., Johnston, D.T., 2013. Authigenic carbonate and the history of the global carbon cycle. Science 339, 540-543.

Schrag, D.P., Berner, R.A., Hoffman, P., Halverson, G.P., 2002. On the initiation of a snowball Earth. Geochemistry, Geophysics, Geosystems 3, 1-21.

Scott, C., Lyons, T.W., 2012. Contrasting molybdenum cycling and isotopic properties in euxinic versus non-euxinic sediments and sedimentary rocks: Refining the paleoproxies. Chemical Geology 324-325, 19-27.

Scott, C., Lyons, T.W., Bekker, A., Shen, Y., Poulton, S.W., Chu, X., Anbar, A., 2008. Stepwise oxygenation of the Proterozoic ocean. Nature Letters 452, 456-459.

Scott, C., Wing, B.A., Bekker, A., Planavsky, N., Medvedev, P., Bates, S.M., Yun, M., Lyons, T.W., 2014. Pyrite multiple-sulfur isotope evidence for rapid expansion and contraction of the early Paleoproterozoic seawater sulfate reservoir. Earth and Planetary Science Letters 389, 95-104.

Sherman, A.G., James, N.P., Narbonne, G.M., 2000. Sedimentology of a Late Mesoproterozoic muddy carbonate ramp, northern Baffin Island, Arctic Canada. In: J.P. Grotzinger, N.P. James (Eds.), Carbonate sedimentation and diagenesis in the evolving Precambrian world. Society for Sedimentary Geology, pp. 275-294.

Smith, A. G., 2009, Neoproterozoic timescales and stratigraphy: Geological Society, London, Special Publications, v. 326, p. 27-54.

Sperling, E.A., Halverson, G.P., Knoll, A.H., Macdonald, F.A., Johnston, D.T., 2013. A basin redox transect at the dawn of animal life. Earth and Planetary Science Letters 371 $372,143-155$.

Swanson-Hysell, N.L. et al., 2010. Cryogenian glaciation and the onset of carbon-isotope decoupling. Science, 328: 608-610. 
Swart, P.K., Kennedy, M.J., 2012. Does the global stratigraphic reproducibility of delta13C in Neoproterozoic carbonates require a marine origin? A Pliocene-Pleistocene comparison. Geology 40, 87-90.

Thomas, C.W., Graham, C.M., Ellam, R.M., Fallick, A.E., 2004. 87Sr/86Sr chemostratigraphy of Neoproterozoic Dalradian limestones of Scotland and Ireland: constraints of depositional ages and time scales. Journal of the Geological Society 161, 229-242.

Thomson, D., Rainbird, R.H., Prince, J., Krapez, B., 2012. Reconstruction of an early Neoproterozoic carbonate-evaporite ramp from Northwest Territories, Canada, International Geological Congress, Brisbane, Australia.

Thomson, D., Rainbird, R.H., Dix, G., 2014. Architecture of a Neoproterozoic intracratonic carbonate ramp succession: Wynniatt Formation, Amundsen Basin, Arctic Canada. Sedimentary Geology, 299: 119-138.

Thorsteinsson, R., Tozer, E.T., 1962. Banks, Victoria and Stefansson Islands, Arctic Archipelago. Geological Survey of Canada, Memoir 330: 1-85.

Tosca, N.J., Macdonald, F.A., Strauss, J.V., Johnston, D.T., Knoll, A.H., 2011. Sedimentary talc in Neoproterozoic carbonate successions. Earth and Planetary Science Letters, 306: 11-22.

Turner, E.C., Long, D.G.F., 2008. Basin architecture and syndepositional fault activity during deposition of the Neoproterozoic Mackenzie Mountains supergroup, Northwest Territories, Canada. Canadian Journal of Earth Sciences, 45: 1159-1184.

Turner, E.C., Long, D.G.F., 2012. Formal definition of the Neoproterozoic Mackenzie Mountains Supergroup (Northwest Territories), and formal stratigraphic nomenclature for its carbonate and evaporite formations. Geological Survey of Canada, Open File 7112: 157.

van Acken, D., Thomson, D., Rainbird, R.H., Creaser, R.A., 2013. Constraining the depositional history of the Neoproterozoic Shaler Supergroup, Amundsen Basin, NW Canada: Rhenium-osmium dating of black shales from the Wynniatt and Boot Inlet Formations. Precambrian Research, 236: 124-131.

Vecsei, A., and Duringer, P., 2003, Sequence stratigraphy of Middle Triassic carbonates and terrigenous deposits (Muschelkalk and Lower Keuper) in the SW Germanic Basin: maximum flooding versus maximum depth in cratonic basins: Sedimentary Geology, v. 160, p. 81-105.

Veizer, J., 1989. Strontium isotopes in seawater through time. Annual Review of Earth and Planetary Sciences 17, 141-167. 
Walker, R.G., Plint, A.G., 1992. Wave- and storm-dominated shallow marine systems. In: R.G. Walker, N.P. James (Eds.), Facies Models: Response to sea level change. Geological Association of Canada, pp. 219-238.

Walter, M.R., 1972. Stromatolites and the biostratigraphy of the Australian Precambrian and Cambrian. Special Papers in Palaeontology No.11. Palaeontological Association of London.

Walter, M.R., Veevers, J.J., Calver, C.R., Gorjan, P., Hill, A.C., 2000. Dating the 840$544 \mathrm{Ma}$ Neoproterozoic interval by isotopes of strontium, carbon, and sulfur in seawater, and some interpretative models. Precambrian Research, 100: 371-433.

Wang, X.-C., Li, X.H., Li, W.X., Li, Z.X., Liu, Y., Yang, Y.H., Liang, X.R., and Tu, X.L., 2008. The Bikou basalts in the northwestern Yangtze block, South China: Remnants of 820-810 Ma continental flood basalts? Geological Society of America Bulletin, 120(11-12): 1478-1492.

Wedepohl, K.H., 1995. The composition of the continental crust. Geochemica et Cosmochimica Acta 59, 1217-1232.

Williams, G.D., Stelck, C.R., 1975. Speculations on the Cretaceous paleogeography of North America. In: W.G.E. Caldwell (Ed.), The Cretaceous system in the Western Interior of North America. Geological Association of Canada, Special Paper Number 13, pp. $1-20$.

Wingate, M.T.D., Campbell, I.H., Compston, W., Gibson, G.M., 1998. Ion microprobe $\mathrm{U}-\mathrm{Pb}$ ages for Neoproterozoic basaltic magmatism in south-central Australia and implications for the break-up of Rodinia. Precambrian Research, 87: 135-159.

Wingate, M. T. D., and Giddings, J. W., 2000, Age and palaeomagnetism of the Mundine Well dyke swarm, Western Australia: implications for an Australia-Laurentia connection at 755 Ma: Precambrian Research, v. 100, no. 335-357.

Xie, X., and Heller, P., 2009, Plate tectonics and basin subsidence history: GSA Bulletin, v. 121 , no. $1 / 2$, p. 55-64.

Young, G.M., 1977. Stratigraphic correlation of upper Proterozoic rocks of northwestern Canada. Canadian Journal of Earth Sciences, 14: 1771-1787.

Young, G.M., 1981. The Amundsen embayment, Northwest Territories; Relevance to the Upper Proterozoic evolution of North America. Geological Survey of Canada, Paper 8110: 203-218.

Young, G.M., and Jefferson, C.W., 1975, Late Precambrian shallow water deposits, Banks and Victoria Islands, Arctic Archipelago: Canadian Journal of Earth Sciences, v. 12, p. 1734-1748. 
Young, G.M., and Long, D.G.F., 1977, Carbonate sedimentation in a late Precambrian shelf sea, Victoria Island, Canadian Arctic Archipelago: Journal of Sedimentary Petrology, v. 47, p. 943-955.

Young, G.M., Jefferson, C.W., Delaney, G.D., Yeo, G.M., 1979. Middle and late Proterozoic evolution of the northern Canadian Cordillera and Shield. Geology, 7: 125128.

Zhao, J., McCulloch, M.T., Korsch, R.J., 1994. Characterization of a plume-related $\sim 800$ Ma magmatic event and its implications for basin formation in central-southern Australia. Earth and Planetary Science Letters 121, 349-367. 


\section{Appendixes}




\begin{tabular}{|c|c|c|c|c|}
\hline Section & Latitude & Longitute & Notes & $\begin{array}{l}\text { GSC station } \\
\text { number }\end{array}$ \\
\hline \multicolumn{5}{|c|}{ Outcrop Sections } \\
\hline 10DTS1 & 71.322 & -115.5826 & Minto Inlet Fm. & 10RAT-DT022 \\
\hline 10DTS2 & 71.2602 & -116.0748 & Minto Inlet Fm. & 10RAT-DT024 \\
\hline 10DTS3 & 71.4418 & -116.0118 & lower carbonate member & 10RAT-DT027 \\
\hline 10DTS4 & 71.4219 & -116.0693 & black shale member & 10RAT-DT030 \\
\hline 10DTS5 & 71.4761 & -115.5157 & $\begin{array}{l}\text { stromatolitic carbonate } \\
\text { member }\end{array}$ & 10RAT-DT055 \\
\hline 10DTS6 & 71.3795 & -115.1603 & upper carbonate member & 10RAT-DT057 \\
\hline 10DTS7 & 71.4453 & -115.2464 & $\begin{array}{l}\text { stromatolitic carbonate } \\
\text { member }\end{array}$ & 10RAT-DT058 \\
\hline 10DTS8 & 71.4374 & -115.2262 & $\begin{array}{l}\text { upper carbonate member, } \\
\text { west side of river }\end{array}$ & 10RAT-DT060 \\
\hline 10DTS9 & 71.4265 & -115.1988 & $\begin{array}{l}\text { upper carbonate member, } \\
\text { east side of river }\end{array}$ & 10RAT-DT062 \\
\hline 10DTS10 & 72.1982 & -111.7301 & $\begin{array}{l}\text { stromatolitic carbonate } \\
\text { member }\end{array}$ & 10RAT-DT074 \\
\hline 10DTS11 & 72.2209 & -111.6861 & $\begin{array}{l}\text { lower carbonate and } \\
\text { black shale members }\end{array}$ & 10RAT-DT076 \\
\hline 10DTS12 & 71.3772 & -115.1588 & upper carbonate member & 10RAT-DT105 \\
\hline 11DTS2 & 71.3431 & -115.5731 & $\begin{array}{l}\text { upper carbonate member, } \\
\text { SW side of hill }\end{array}$ & 11RAT-DT029 \\
\hline 11DTS3 & 71.3376 & -115.5552 & $\begin{array}{l}\text { upper carbonate member, } \\
\text { SE side of hill }\end{array}$ & 11RAT-DT034 \\
\hline 11DTS4 & 71.3376 & -115.5552 & $\begin{array}{l}\text { upper carbonate member, } \\
\text { south side of hill }\end{array}$ & 11RAT-DT034 \\
\hline 11DTS5 & 71.1725 & -117.1078 & upper carbonate member & 11RAT-DT102 \\
\hline 11DTS6 & 71.4515 & -117.1434 & Fort Collinson Fm. & 11RAT-DT127 \\
\hline 11DTS7 & 71.3241 & -116.4923 & upper carbonate member & 11RAT-DT129 \\
\hline 11DTS8 & 71.4521 & -117.1236 & Jago Bay Fm. & 11RAT-DT147 \\
\hline
\end{tabular}

\begin{tabular}{|l|r|r|l|l|}
\hline 11DTS9 & 72.1222 & -112.2748 & $\begin{array}{l}\text { lower carbonate, black } \\
\text { shale, and stromatolitic } \\
\text { carbonate members }\end{array}$ & 11RAT-DT168 \\
\hline Drill core & 71.6282 & -115.8962 & $\begin{array}{l}\text { Minto Inlet Fm. and } \\
\text { lower carbonate member, } \\
\text { Wynniatt Fm. }\end{array}$ & 10RAT-DT111 \\
\hline GNME 06-03 & 71.7286 & -113.6019 & $\begin{array}{l}\text { upper carbonate Member } \\
\text { unME 07-04 }\end{array}$ & 11RAT-DT095 \\
\hline
\end{tabular}

Appendix 1. Locations and descriptions of measured outcrop sections and drill core. 
Appendix 2. Stable isotope data

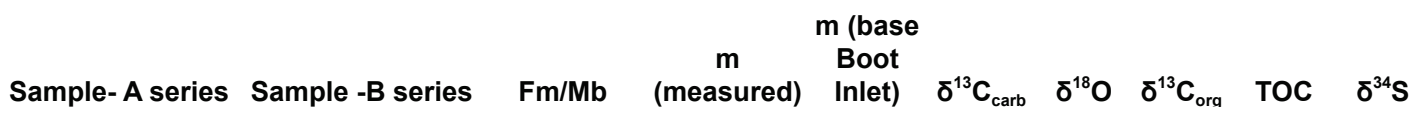

\begin{tabular}{|c|c|c|c|c|c|c|c|c|}
\hline 10RAT-DT022A1 & Minto & 1 & 472.7 & & & & & \\
\hline 10RAT-DT022A2 & Minto & 19 & 490.7 & & & & & \\
\hline 10RAT-DT022A3 & Minto & 20 & 491.7 & & & & & \\
\hline 10RAT-DT022A4 & Minto & 22 & 493.7 & 3.94 & -4.52 & & & \\
\hline 10RAT-DT022A5 & Minto & 26.5 & 498.2 & 3.90 & -9.02 & & & \\
\hline 10RAT-DT022A6 & Minto & 66 & 537.7 & 3.23 & -8.50 & & & \\
\hline 10RAT-DT022A7 & Minto & 67.2 & 538.9 & 3.40 & -8.71 & & & \\
\hline 10RAT-DT024A1 & Minto & 2.8 & 599.5 & & & & & \\
\hline 10RAT-DT024A2 & Minto & 5 & 601.7 & & & & & \\
\hline 10RAT-DT024A3 & Minto & 17.5 & 614.2 & & & & & \\
\hline 10RAT-DT024A4 & Minto & 21.1 & 617.8 & 0.45 & -8.18 & & & \\
\hline 10RAT-DT024A5 & Minto & 26.4 & 623.1 & 1.67 & -9.13 & & & \\
\hline 10RAT-DT024A6 & Minto & 27 & 623.7 & & & & & \\
\hline 10RAT-DT024A7 & Minto & 27.4 & 624.1 & 2.32 & -8.08 & & & \\
\hline 10RAT-DT024A8 & Minto & 28 & 624.7 & 0.72 & -8.74 & & & \\
\hline 10RAT-DT024A9 & Minto & 30.4 & 627.1 & 4.14 & -6.66 & & & \\
\hline 10RAT-DT024A10 & Minto & 31.9 & 628.6 & 3.48 & -6.05 & & & \\
\hline 10RAT-DT024A11 & Minto & 32.9 & 629.6 & 2.93 & -7.73 & & & \\
\hline 10RAT-DT024A12 & Minto & 34 & 630.7 & 3.22 & -6.27 & & & \\
\hline 10RAT-DT024A13 & Minto & 34.9 & 631.6 & 3.49 & -4.67 & & & \\
\hline 10RAT-DT024A14 & Minto & 36.1 & 632.8 & 3.53 & -7.45 & & & \\
\hline 10RAT-DT024A15 & Minto & 36.7 & 633.4 & 3.14 & -8.53 & & & \\
\hline 10RAT-DT024A16 & Minto & 37.7 & 634.4 & 1.31 & -8.67 & & & \\
\hline 10RAT-DT024A17 & Minto & 38.6 & 635.3 & 1.28 & -8.13 & & & \\
\hline 10RAT-DT024A18 & Minto & 40.9 & 637.6 & & & & & \\
\hline 10RAT-DT024A19 & Minto & 43 & 639.7 & -1.33 & -11.30 & & & \\
\hline 10RAT-DT027A1 & $\mathrm{Icm}$ & 1 & 657.7 & 4.51 & -8.89 & & & \\
\hline 10RAT-DT027A2 & $\mathrm{Icm}$ & 7.4 & 664.1 & 4.94 & -6.01 & -24.40 & 0.20 & \\
\hline 10RAT-DT027A3 & $\mathrm{Icm}$ & 16 & 672.7 & 3.27 & -3.97 & & & \\
\hline 10RAT-DT027A4 & $\mathrm{Icm}$ & 17 & 673.7 & 2.66 & -4.28 & & & \\
\hline 10RAT-DT027A5 & $\mathrm{Icm}$ & 20 & 676.7 & 4.62 & -6.65 & & & \\
\hline 10RAT-DT027A6 & $\mathrm{Icm}$ & 25.3 & 682 & 3.72 & -5.60 & & & \\
\hline 10RAT-DT027A7 & $\mathrm{Icm}$ & 37.5 & 694.2 & 3.23 & -5.53 & & & \\
\hline 10RAT-DT027A8 & $\mathrm{Icm}$ & 41 & 697.7 & 3.24 & -5.53 & & & \\
\hline 10RAT-DT027A9 & $\mathrm{Icm}$ & 45.5 & 702.2 & 3.99 & -8.00 & & & \\
\hline 10RAT-DT027A10 & $\mathrm{Icm}$ & 46.5 & 703.2 & 3.38 & -3.36 & & & \\
\hline 10RAT-DT027A11 & $\mathrm{Icm}$ & 53 & 709.7 & 4.48 & -8.93 & -25.00 & 0.43 & -4.00 \\
\hline 10RAT-DT027A12 & $\mathrm{Icm}$ & 57.1 & 713.8 & 4.94 & -8.61 & -22.70 & 0.13 & \\
\hline 10RAT-DT027A13 & $\mathrm{Icm}$ & 61.1 & 717.8 & 5.12 & -4.77 & -24.70 & 0.22 & \\
\hline 10RAT-DT027A14 & $\mathrm{Icm}$ & 66.1 & 722.8 & 5.33 & -6.47 & & & \\
\hline 10RAT-DT027A15 & $\mathrm{Icm}$ & 67.8 & 724.5 & 4.66 & -6.93 & -24.70 & 0.27 & \\
\hline 10RAT-DT027A16 & $\mathrm{Icm}$ & 72.7 & 729.4 & 4.84 & -4.68 & & & \\
\hline 10RAT-DT027A17 & $\mathrm{Icm}$ & 79.4 & 736.1 & 4.84 & -3.65 & & & \\
\hline 10RAT-DT027A19 & $\mathrm{Icm}$ & 91.6 & 748.3 & 4.40 & -9.41 & -23.20 & 1.02 & \\
\hline 10RAT-DT027A20 & $\mathrm{Icm}$ & 99.15 & 755.85 & 5.34 & -7.37 & & & \\
\hline 10RAT-DT027A21 & $\mathrm{Icm}$ & 107.5 & 764.2 & 3.14 & -7.43 & & & \\
\hline 10RAT-DT027A22 & $\mathrm{Icm}$ & 113.2 & 769.9 & 2.98 & -8.13 & & & \\
\hline 10RAT-DT027A23 & $\mathrm{Icm}$ & 118 & 774.7 & 4.11 & -9.56 & & & \\
\hline 10RAT-DT027A24 & $\mathrm{Icm}$ & 124 & 780.7 & 4.62 & -8.23 & & & \\
\hline 10RAT-DT030A1 & bsm & 0.5 & 781.2 & 4.29 & -9.60 & & & \\
\hline
\end{tabular}




\begin{tabular}{|c|c|c|c|c|c|c|c|c|}
\hline Sample- A series & Sample -B series & m & (base) & $\delta^{13} C_{\text {carb }}$ & $\delta^{18} O$ & $\delta^{13} C_{\text {ora }}$ & TOC & $\delta^{34} S$ \\
\hline 10RAT-DT030A4 & bsm & 8.8 & 789.5 & 2.65 & -8.72 & & & \\
\hline 10RAT-DT030A5 & bsm & 11.4 & 792.1 & 0.84 & -9.82 & & & \\
\hline 10RAT-DT030A6 & bsm & 12.4 & 793.1 & 0.99 & -8.89 & -24.60 & 0.15 & \\
\hline 10RAT-DT030A7 & bsm & 18 & 798.7 & -0.01 & -7.71 & -25.90 & 0.14 & 13.20 \\
\hline 10RAT-DT030A8 & bsm & 23 & 803.7 & 0.12 & -8.63 & & & \\
\hline 10RAT-DT030A9 & bsm & 26.1 & 806.8 & -0.56 & -8.89 & & & \\
\hline 10RAT-DT030A10 & bsm & 54 & 834.7 & & & & & \\
\hline 10RAT-DT030A11 & bsm & 62.5 & 843.2 & -3.48 & -9.69 & & & \\
\hline 10RAT-DT030A12 & bsm & 73.5 & 854.2 & & & -21.70 & 0.11 & 10.60 \\
\hline 10RAT-DT030A13 & bsm & 89 & 869.7 & & & & & \\
\hline 10RAT-DT030A14 & bsm & 93 & 873.7 & & & & & \\
\hline 10RAT-DT052A1 & bsm & 5.7 & 932.4 & & & & & \\
\hline 10RAT-DT052A2 & bsm & 40.2 & 966.9 & 2.64 & -9.22 & & & \\
\hline 10RAT-DT052A3 & bsm & 43.6 & 970.3 & 3.25 & -4.54 & & & \\
\hline 10RAT-DT052A4 & bsm & 45.9 & 972.6 & & & & & \\
\hline 10RAT-DT052A5 & bsm & 46.8 & 973.5 & 2.56 & -6.90 & & & \\
\hline 10RAT-DT055A1 & bsm & 1 & 908.4 & & & & & \\
\hline 10RAT-DT055A2 & bsm & 53 & 960.4 & & & & & \\
\hline 10RAT-DT055A3 & bsm & 68 & 975.4 & 2.18 & -8.78 & & & \\
\hline 10RAT-DT055A4 & bsm & 67.5 & 974.9 & & & & & \\
\hline 10RAT-DT055A5 & $\mathrm{scm}$ & 71.8 & 979.2 & 3.72 & -5.63 & & & \\
\hline 10RAT-DT055A6 & $\mathrm{scm}$ & 73.5 & 980.9 & 4.34 & -4.97 & & & \\
\hline 10RAT-DT055A7 & $\mathrm{scm}$ & 75.2 & 982.6 & 4.03 & -4.58 & & & \\
\hline 10RAT-DT055A8 & $\mathrm{scm}$ & 75.3 & 982.7 & & & & & \\
\hline 10RAT-DT055A9 & $\mathrm{scm}$ & 77 & 984.4 & & & & & \\
\hline 10RAT-DT055A10 & $\mathrm{scm}$ & 80 & 987.4 & 4.29 & -3.49 & & & \\
\hline 10RAT-DT055A11 & $\mathrm{scm}$ & 85.4 & 992.8 & 4.13 & -8.98 & & & \\
\hline 10RAT-DT055A12 & $\mathrm{scm}$ & 87.2 & 994.6 & & & & & \\
\hline 10RAT-DT055A13 & $\mathrm{scm}$ & 87.7 & 995.1 & 4.60 & -8.33 & & & \\
\hline 10RAT-DT055A14 & $\mathrm{scm}$ & 90.9 & 998.3 & 2.54 & -8.88 & & & \\
\hline 10RAT-DT055A15 & $\mathrm{scm}$ & 92.5 & 999.9 & 6.97 & -7.60 & & & \\
\hline 10RAT-DT055A16 & $\mathrm{scm}$ & 97.1 & 1004.5 & 4.77 & -8.65 & & & \\
\hline 10RAT-DT057A1 & ucm & 0.5 & 1375.4 & & & & & \\
\hline 10RAT-DT057A2 & $\mathrm{ucm}$ & 1.6 & 1376.5 & 4.40 & -5.02 & & & \\
\hline 10RAT-DT057A3 & $\mathrm{ucm}$ & 7.8 & 1382.7 & 5.52 & -5.26 & -23.94 & 0.67 & \\
\hline 10RAT-DT057A4 & $\mathrm{ucm}$ & 9.8 & 1384.7 & 5.13 & -5.32 & & & \\
\hline 10RAT-DT057A5 & $\mathrm{ucm}$ & 16.6 & 1391.5 & 4.28 & -6.98 & & & \\
\hline 10RAT-DT057A6 & $\mathrm{ucm}$ & 17 & 1391.9 & & & & & \\
\hline 10RAT-DT057A8 & ucm & 25.6 & 1400.5 & 3.96 & -6.15 & & & \\
\hline 10RAT-DT057A9 & $\mathrm{ucm}$ & 25.75 & 1400.65 & 2.41 & -6.09 & & & \\
\hline 10RAT-DT057A10 & $\mathrm{ucm}$ & 27.9 & 1402.8 & 4.07 & -7.70 & -26.29 & 0.19 & \\
\hline 10RAT-DT057A11 & ucm & 29.5 & 1404.4 & & & & & \\
\hline 10RAT-DT057A12 & $\mathrm{ucm}$ & 30.6 & 1405.5 & 3.25 & -5.02 & & & \\
\hline 10RAT-DT057A13 & $\mathrm{ucm}$ & 35.9 & 1410.8 & 3.00 & -6.22 & & & \\
\hline 10RAT-DT057A14 & $\mathrm{ucm}$ & 41.8 & 1416.7 & 2.83 & -7.50 & & & \\
\hline 10RAT-DT058A1 & $\mathrm{scm}$ & 1 & 975.9 & 2.38 & -9.30 & & & \\
\hline 10RAT-DT058A2 & $\mathrm{scm}$ & 10.6 & 985.5 & 4.04 & -4.73 & & & \\
\hline 10RAT-DT058A3 & $\mathrm{scm}$ & 15.1 & 990 & & & & & \\
\hline 10RAT-DT058A4 & $\mathrm{scm}$ & 18.3 & 993.2 & 5.60 & -8.83 & & & \\
\hline 10RAT-DT058A5 & $\mathrm{scm}$ & 23 & 997.9 & 6.36 & -7.31 & & & \\
\hline 10RAT-DT058A6 & $\mathrm{scm}$ & 26 & 1000.9 & 5.64 & -7.33 & & & \\
\hline 10RAT-DT058A7 & $\mathrm{scm}$ & 37.6 & 1012.5 & 7.67 & -8.03 & & & \\
\hline 10RAT-DT058A8 & $\mathrm{scm}$ & 44.1 & 1019 & 7.16 & -8.71 & & & \\
\hline 10RAT-DT058A9 & $\mathrm{scm}$ & 47.2 & 1022.1 & 6.49 & -8.10 & -24.27 & 0.27 & -12.60 \\
\hline 10RAT-DT058A10 & $\mathrm{scm}$ & 55 & 1029.9 & 4.51 & -7.69 & & & \\
\hline 10RAT-DT058A11 & $\mathrm{scm}$ & 57.8 & 1032.7 & 4.99 & -7.97 & & & \\
\hline
\end{tabular}




\begin{tabular}{|c|c|c|}
\hline Sample-A series & Sample -B series & $\mathrm{Fm} / \mathrm{Mb}$ \\
\hline 10RAT-DT058A13 & & $\mathrm{scm}$ \\
\hline 10RAT-DT058A14 & & $\mathrm{scm}$ \\
\hline 10RAT-DT058A15 & & $\mathrm{scm}$ \\
\hline 10RAT-DT060A1 & & $\mathrm{scm}$ \\
\hline 10RAT-DT060A2 & & $\mathrm{scm}$ \\
\hline 10RAT-DT060A3 & & $\mathrm{scm}$ \\
\hline 10RAT-DT060A4 & & $\mathrm{scm}$ \\
\hline 10RAT-DT060A5 & & $\mathrm{scm}$ \\
\hline 10RAT-DT060A6 & & $\mathrm{scm}$ \\
\hline 10RAT-DT060A7 & & $\mathrm{scm}$ \\
\hline 10RAT-DT060A8 & & $\mathrm{scm}$ \\
\hline 10RAT-DT060A9 & & $\mathrm{scm}$ \\
\hline 10RAT-DT060A10 & & $\mathrm{scm}$ \\
\hline 10RAT-DT060A11 & & $\mathrm{scm}$ \\
\hline 10RAT-DT060A19 & & $\mathrm{scm}$ \\
\hline 10RAT-DT060A20 & & $\mathrm{scm}$ \\
\hline 10RAT-DT060A21 & & $\mathrm{scm}$ \\
\hline 10RAT-DT060A22 & & $\mathrm{scm}$ \\
\hline 10RAT-DT060A23 & & $\mathrm{scm}$ \\
\hline 10RAT-DT060A24 & & $\mathrm{scm}$ \\
\hline 10RAT-DT060A25 & & $\mathrm{scm}$ \\
\hline 10RAT-DT060A26 & & $\mathrm{ucm}$ \\
\hline 10RAT-DT060A27 & & $\mathrm{ucm}$ \\
\hline 10RAT-DT060A12 & & $\mathrm{ucm}$ \\
\hline 10RAT-DT060A28 & & $\mathrm{ucm}$ \\
\hline 10RAT-DT060A29 & & ucm \\
\hline 10RAT-DT060A30 & & $\mathrm{ucm}$ \\
\hline 10RAT-DT060A31 & & $\mathrm{ucm}$ \\
\hline 10RAT-DT060A33 & & $\mathrm{ucm}$ \\
\hline 10RAT-DT060A34 & & $\mathrm{ucm}$ \\
\hline 10RAT-DT060A13 & & $\mathrm{ucm}$ \\
\hline 10RAT-DT060A14 & & $\mathrm{ucm}$ \\
\hline 10RAT-DT060A15 & & ucm \\
\hline 10RAT-DT060A16 & & $\mathrm{ucm}$ \\
\hline 10RAT-DT060A17 & & $\mathrm{ucm}$ \\
\hline 10RAT-DT060A18 & & $\mathrm{ucm}$ \\
\hline 10RAT-DT062A1 & & $\mathrm{ucm}$ \\
\hline 10RAT-DT062A2 & & $\mathrm{ucm}$ \\
\hline 10RAT-DT062A3 & & $\mathrm{ucm}$ \\
\hline 10RAT-DT062A4 & & $\mathrm{ucm}$ \\
\hline 10RAT-DT062A5 & & $\mathrm{ucm}$ \\
\hline 10RAT-DT062A6 & & $\mathrm{ucm}$ \\
\hline 10RAT-DT062A7 & & $\mathrm{ucm}$ \\
\hline 10RAT-DT062A8 & & $\mathrm{ucm}$ \\
\hline 10RAT-DT062A9 & & $\mathrm{ucm}$ \\
\hline 10RAT-DT062A10 & & $\mathrm{ucm}$ \\
\hline 10RAT-DT062A11 & & $\mathrm{ucm}$ \\
\hline 10RAT-DT062A12 & & $\mathrm{ucm}$ \\
\hline 10RAT-DT062A13 & & $\mathrm{ucm}$ \\
\hline 10RAT-DT074A1 & & $\mathrm{scm}$ \\
\hline 10RAT-DT074A2 & & $\mathrm{scm}$ \\
\hline 10RAT-DT074A3 & & $\mathrm{scm}$ \\
\hline 10RAT-DT074A4 & & $\mathrm{scm}$ \\
\hline 10RAT-DT074A5 & & $\mathrm{scm}$ \\
\hline 10RAT-DT074A6 & & $\mathrm{scm}$ \\
\hline 10RAT-DT074A7 & & $\mathrm{scm}$ \\
\hline
\end{tabular}

\begin{tabular}{|c|c|c|c|c|c|c|}
\hline m & (base) & $\delta^{13} C_{\text {carb }}$ & $\delta^{18} \mathrm{O}$ & $\delta^{13} C_{\text {ora }}$ & TOC & $\delta^{34} S$ \\
\hline 70.9 & 1045.8 & 4.70 & -8.59 & & & \\
\hline 80.9 & 1055.8 & 5.75 & -7.27 & & & \\
\hline 99.9 & 1074.8 & 4.37 & -8.76 & & & \\
\hline 1.3 & 1081.2 & 4.42 & -8.14 & & & \\
\hline 7.5 & 1087.4 & 5.01 & -8.88 & & & \\
\hline 13 & 1092.9 & 5.10 & -7.60 & & & \\
\hline 17 & 1096.9 & 4.98 & -8.06 & -25.85 & 0.53 & \\
\hline 25.8 & 1105.7 & 5.86 & -8.26 & & & \\
\hline 30 & 1109.9 & 6.44 & -8.22 & & & \\
\hline 35.9 & 1115.8 & 6.34 & -8.00 & & & \\
\hline 40 & 1119.9 & 6.29 & -8.28 & & & \\
\hline 43.5 & 1123.4 & 5.37 & -7.10 & & & \\
\hline 49.5 & 1129.4 & 5.92 & -2.74 & & & \\
\hline 52.6 & 1132.5 & 5.20 & -5.06 & & & \\
\hline 53.1 & 1133 & 4.85 & -3.99 & & & \\
\hline 53.6 & 1133.5 & 5.12 & -4.16 & & & \\
\hline 54.1 & 1134 & 4.98 & -4.46 & & & \\
\hline 54.6 & 1134.5 & 4.39 & -5.38 & & & \\
\hline 55.1 & 1135 & 4.62 & -5.40 & -25.38 & 0.75 & -18.40 \\
\hline 55.6 & 1135.5 & 3.94 & -4.35 & & & \\
\hline 56.1 & 1136 & 1.10 & -5.13 & & & \\
\hline 56.3 & 1136.2 & 0.77 & -7.37 & & & \\
\hline 56.6 & 1136.5 & 1.29 & -7.97 & & & \\
\hline 57 & 1136.9 & -0.12 & -5.14 & & & \\
\hline 57.3 & 1137.2 & -0.18 & -4.23 & & & \\
\hline 57.6 & 1137.5 & -0.16 & -5.78 & & & \\
\hline 58 & 1137.9 & -1.19 & -6.71 & & & \\
\hline 58.2 & 1138.1 & & & & & \\
\hline 60.2 & 1140.1 & -2.85 & -7.94 & & & \\
\hline 62.2 & 1142.1 & -2.06 & -9.16 & & & \\
\hline 65.7 & 1145.60 & -5.50 & -9.38 & & & \\
\hline 79 & 1158.9 & & & & & \\
\hline 80 & 1159.9 & & & & & \\
\hline 85 & 1164.9 & -5.56 & -8.32 & & & \\
\hline 97.1 & 1177 & & & & & \\
\hline 97.1 & 1177 & & & & & \\
\hline 3 & 1217.9 & 3.62 & -7.66 & & & \\
\hline 10.8 & 1225.7 & & & & & \\
\hline 11.35 & 1226.25 & & & & & \\
\hline 10.2 & 1225.1 & & & & & \\
\hline 12.4 & 1227.3 & 2.30 & -6.50 & & & \\
\hline 18 & 1232.9 & 1.94 & -7.03 & & & \\
\hline 23 & 1237.9 & 5.71 & -6.12 & -24.12 & 0.37 & \\
\hline 28.5 & 1243.4 & 5.51 & -5.92 & -22.21 & 0.74 & 12.5 \\
\hline 42.5 & 1257.4 & 5.14 & -8.39 & & & \\
\hline 60 & 1274.9 & 6.22 & -6.33 & & & \\
\hline 68 & 1282.9 & 5.83 & -7.48 & & & \\
\hline 82 & 1296.9 & 6.21 & -6.84 & & & \\
\hline 93 & 1307.9 & 5.72 & -8.35 & & & \\
\hline 9 & 973.6 & & & & & \\
\hline 10.3 & 974.9 & 0.58 & -9.28 & & & \\
\hline 15 & 979.6 & & & & & \\
\hline 17.6 & 982.2 & & & & & \\
\hline 22 & 986.6 & 6.76 & -6.29 & & & \\
\hline 26.4 & 991 & 5.98 & -6.31 & -25.99 & 0.42 & -13.5 \\
\hline 32.1 & 996.7 & 5.75 & -5.38 & -23.69 & 0.16 & \\
\hline
\end{tabular}




\begin{tabular}{|c|c|c|c|c|c|c|c|c|c|}
\hline Sample-A series & Sample -B series & $\mathrm{Fm} / \mathrm{Mb}$ & m & (base) & $\delta^{13} C_{\text {carb }}$ & $\delta^{18} O$ & $\delta^{13} \mathrm{C}_{\text {ora }}$ & TOC & $\delta^{34} S$ \\
\hline 10RAT-DT074A9 & & $\mathrm{scm}$ & 51.5 & 1016.1 & 6.36 & -6.03 & & & \\
\hline 10RAT-DT074A10 & & $\mathrm{scm}$ & 58 & 1022.6 & 6.48 & -5.62 & & & \\
\hline 10RAT-DT074A11 & & $\mathrm{scm}$ & 63 & 1027.6 & 5.08 & -7.42 & & & \\
\hline 10RAT-DT074A12 & & $\mathrm{scm}$ & 68 & 1032.6 & 5.14 & -6.98 & -25.43 & 0.20 & \\
\hline 10RAT-DT074A13 & & $\mathrm{scm}$ & 72.8 & 1037.4 & 5.55 & -6.86 & -24.57 & 0.87 & -13.5 \\
\hline 10RAT-DT074A14 & & $\mathrm{scm}$ & 77.8 & 1042.4 & 4.84 & -6.80 & -25.31 & 0.14 & \\
\hline 10RAT-DT074A15 & & $\mathrm{scm}$ & 85.9 & 1050.5 & 4.64 & -8.73 & & & \\
\hline 10RAT-DT074A16 & & $\mathrm{scm}$ & 87.8 & 1052.4 & 4.46 & -9.75 & & & \\
\hline 10RAT-DT074A17 & & $\mathrm{scm}$ & 90.3 & 1054.9 & 5.08 & -8.16 & -26.03 & 0.22 & \\
\hline 10RAT-DT074A18 & & $\mathrm{scm}$ & 94.8 & 1059.4 & 5.16 & -7.88 & & & \\
\hline 10RAT-DT074A19 & & $\mathrm{scm}$ & 101 & 1065.6 & 5.62 & -6.33 & & & \\
\hline 10RAT-DT076A1 & & $\mathrm{Icm}$ & 0.3 & 740 & 5.55 & -5.87 & & & \\
\hline 10RAT-DT076A2 & & $\mathrm{Icm}$ & 1.1 & 740.8 & 4.94 & -6.93 & & & \\
\hline 10RAT-DT076A3 & & $\mathrm{Icm}$ & 5 & 744.7 & 4.64 & -6.13 & & & \\
\hline 10RAT-DT076A4 & & $\mathrm{Icm}$ & 10.5 & 750.2 & 4.90 & -6.98 & & & \\
\hline 10RAT-DT076A5 & & $\mathrm{Icm}$ & 15 & 754.7 & 4.82 & -7.86 & -25.33 & 0.07 & \\
\hline 10RAT-DT076A6 & & $\mathrm{Icm}$ & 20 & 759.7 & 3.71 & -5.73 & -23.88 & 0.06 & \\
\hline 10RAT-DT076A7 & & $\mathrm{Icm}$ & 36.4 & 776.1 & 3.86 & -7.60 & & & \\
\hline 10RAT-DT076A9 & & $\mathrm{Icm}$ & 44.7 & 784.4 & 2.58 & -9.17 & & & \\
\hline 10RAT-DT105A1 & & $\mathrm{ucm}$ & 0.3 & 1417 & 2.31 & -5.83 & & & \\
\hline 10RAT-DT105A2 & & $\mathrm{ucm}$ & 4.7 & 1421.4 & 3.71 & -8.04 & & & \\
\hline 10RAT-DT105A3 & & $\mathrm{ucm}$ & 6.2 & 1422.9 & & & & & \\
\hline 10RAT-DT105A4 & & $\mathrm{ucm}$ & 11.4 & 1428.1 & 4.40 & -7.25 & & & \\
\hline 10RAT-DT105A5 & & $\mathrm{ucm}$ & 17 & 1433.7 & 4.37 & -6.51 & & & \\
\hline 10RAT-DT105A6 & & $\mathrm{ucm}$ & 18.8 & 1435.5 & 3.55 & -6.07 & & & \\
\hline 10RAT-DT111A1 & & Minto & 15.8 & 683.4 & 5.14 & -8.44 & & & \\
\hline 10RAT-DT111A2 & & Minto & 17.9 & 681.3 & 4.86 & -9.41 & & & \\
\hline 10RAT-DT111A3 & & Minto & 20.1 & 679.1 & 4.96 & -9.61 & & & \\
\hline 10RAT-DT111A4 & & Minto & 22.1 & 677.1 & 5.01 & -8.52 & & & \\
\hline 10RAT-DT111A5 & 10RAT-DT111B1 & Minto & 22.5 & 676.7 & 4.94 & -8.93 & -21.90 & 0.13 & \\
\hline 10RAT-DT111A6 & 10RAT-DT111B2 & Minto & 23.2 & 676 & 4.37 & -6.89 & -22.10 & 0.01 & \\
\hline 10RAT-DT111A7 & & Minto & 24.1 & 675.1 & 4.51 & -7.58 & & & \\
\hline 10RAT-DT111A8 & & Minto & 25.8 & 673.4 & 2.96 & -10.80 & & & \\
\hline 10RAT-DT111A9 & & Minto & 34.6 & 664.6 & 3.04 & -7.26 & & & \\
\hline 10RAT-DT111A10 & & Minto & 36.4 & 662.8 & 1.51 & -10.70 & & & \\
\hline 10RAT-DT111A11 & 10RAT-DT111B3 & Minto & 36.6 & 662.6 & 1.31 & -11.33 & -23.60 & 0.72 & -9.9 \\
\hline 10RAT-DT111A12 & & Minto & 37 & 662.2 & 1.59 & -11.39 & & & \\
\hline 10RAT-DT111A13 & & Minto & 38.9 & 660.3 & 2.04 & -6.90 & & & \\
\hline 10RAT-DT111A14 & & Minto & 40.9 & 658.3 & 1.60 & -8.97 & & & \\
\hline 10RAT-DT111A15 & & Minto & 46.5 & 652.7 & 1.70 & -10.55 & & & \\
\hline 10RAT-DT111A16 & & Minto & 48.5 & 650.7 & 2.53 & -7.30 & & & \\
\hline 10RAT-DT111A17 & & Minto & 50.4 & 648.8 & 3.34 & -5.56 & & & \\
\hline 10RAT-DT111A18 & & Minto & 52.6 & 646.6 & 2.55 & -9.33 & & & \\
\hline 10RAT-DT111A19 & & Minto & 54.4 & 644.8 & 3.28 & -7.29 & & & \\
\hline 10RAT-DT111A20 & & Minto & 56.3 & 642.9 & 3.92 & -6.94 & & & \\
\hline 10RAT-DT111A21 & & Minto & 58.5 & 640.7 & 3.18 & -11.52 & & & \\
\hline 10RAT-DT111A22 & & Minto & 60.6 & 638.6 & 3.30 & -10.72 & & & \\
\hline 10RAT-DT111A23 & & Minto & 62.4 & 636.8 & 3.85 & -6.90 & & & \\
\hline 10RAT-DT111A24 & & Minto & 64.3 & 634.9 & 3.62 & -7.60 & & & \\
\hline 10RAT-DT111A25 & & Minto & 67.5 & 631.7 & 3.29 & -8.47 & & & \\
\hline 10RAT-DT111A26 & & Minto & 69.5 & 629.7 & 4.06 & -6.49 & & & \\
\hline 10RAT-DT111A27 & & Minto & 70.9 & 628.3 & 3.57 & -6.58 & & & \\
\hline 10RAT-DT111A28 & & Minto & 72.9 & 626.3 & 3.54 & -6.25 & & & \\
\hline 10RAT-DT111A29 & & Minto & 75 & 624.2 & 3.41 & -6.29 & & & \\
\hline 10RAT-DT111A30 & & Minto & 77.1 & 622.1 & 2.00 & -11.39 & & & \\
\hline 10RAT-DT111A31 & & Minto & 79.1 & 620.1 & 2.35 & -11.57 & & & \\
\hline
\end{tabular}




\begin{tabular}{|c|c|c|}
\hline Sample- A series & Sample -B series & $\mathrm{Fm} / \mathrm{Mb}$ \\
\hline 10RAT-DT111A33 & & Minto \\
\hline 10RAT-DT111A34 & & Minto \\
\hline 10RAT-DT111A35 & & Minto \\
\hline 10RAT-DT111A36 & & Minto \\
\hline 10RAT-DT111A37 & & Minto \\
\hline 10RAT-DT111A38 & & Minto \\
\hline 10RAT-DT111A39 & & Minto \\
\hline 10RAT-DT111A40 & & Minto \\
\hline 10RAT-DT111A42 & & Minto \\
\hline 10RAT-DT111A43 & 10RAT-DT111B4 & Minto \\
\hline 10RAT-DT111A44 & & Minto \\
\hline 10RAT-DT111A45 & & Minto \\
\hline 10RAT-DT111A46 & & Minto \\
\hline 10RAT-DT111A47 & & Minto \\
\hline 10RAT-DT111A48 & & Minto \\
\hline 10RAT-DT111A49 & & Minto \\
\hline 10RAT-DT111A50 & & Minto \\
\hline 10RAT-DT111A51 & & Minto \\
\hline 10RAT-DT111A52 & & Minto \\
\hline 10RAT-DT111A53 & & Minto \\
\hline 10RAT-DT111A54 & & Minto \\
\hline 10RAT-DT111A55 & & Minto \\
\hline 10RAT-DT111A56 & & Minto \\
\hline 10RAT-DT111A57 & & Jago \\
\hline 10RAT-DT111A58 & & Jago \\
\hline 10RAT-DT111A59 & & Jago \\
\hline 10RAT-DT111A60 & & Jago \\
\hline 10RAT-DT111A61 & & Jago \\
\hline 10RAT-DT111A62 & & Jago \\
\hline 10RAT-DT111A63 & & Jago \\
\hline 10RAT-DT111A64 & & Jago \\
\hline 10RAT-DT111A65 & & Jago \\
\hline 10RAT-DT111A66 & & Jago \\
\hline 10RAT-DT111A67 & & Jago \\
\hline 10RAT-DT111A68 & & Jago \\
\hline 10RAT-DT111A69 & & Jago \\
\hline 10RAT-DT111A70 & & Jago \\
\hline 10RAT-DT111A71 & & Jago \\
\hline 10RAT-DT111A72 & & Jago \\
\hline 10RAT-DT111A73 & 10RAT-DT111B5 & Jago \\
\hline 10RAT-DT111A74 & & Jago \\
\hline 10RAT-DT111A75 & & Jago \\
\hline 10RAT-DT111A76 & & Jago \\
\hline 10RAT-DT111A77 & & Jago \\
\hline 10RAT-DT111A78 & & Jago \\
\hline 10RAT-DT111A79 & & Jago \\
\hline 10RAT-DT111A80 & 10RAT-DT111B6 & Jago \\
\hline 10RAT-DT111A81 & 10RAT-DT111B7 & Jago \\
\hline 10RAT-DT111A82 & & Jago \\
\hline 10RAT-DT111A83 & & Jago \\
\hline 10RAT-DT111A84 & & Jago \\
\hline 10RAT-DT111A85 & 10RAT-DT111B8 & Jago \\
\hline 10RAT-DT111A86 & & Jago \\
\hline 10RAT-DT111A87 & 10RAT-DT111B9 & Jago \\
\hline 10RAT-DT111A88 & & Jago \\
\hline
\end{tabular}

\begin{tabular}{|c|c|c|c|c|c|c|}
\hline m & $\underset{\text { (base) }}{\mathrm{m}}$ & $\delta^{13} C_{\text {carb }}$ & $\delta^{18} \mathrm{O}$ & $\delta^{13} C_{\text {ora }}$ & TOC & $\delta^{34} S$ \\
\hline 84.5 & 614.7 & 2.29 & -11.98 & & & \\
\hline 86.4 & 612.8 & & & & & \\
\hline 88.4 & 610.8 & 2.10 & -12.36 & & & \\
\hline 90.4 & 608.8 & & & & & \\
\hline 92.3 & 606.9 & 1.68 & -12.51 & & & \\
\hline 94.1 & 605.1 & 2.26 & -13.74 & & & \\
\hline 95.85 & 603.35 & 3.66 & -12.09 & & & \\
\hline 195.4 & 503.8 & 3.71 & -11.97 & & & \\
\hline 201.1 & 498.1 & 2.78 & -12.24 & & & \\
\hline 201.4 & 497.8 & 3.50 & -11.55 & -24.22 & 0.10 & \\
\hline 203 & 496.2 & 3.46 & -11.98 & & & \\
\hline 204.85 & 494.35 & 3.23 & -12.36 & & & \\
\hline 206.9 & 492.3 & 3.74 & -10.01 & & & \\
\hline 209 & 490.2 & 3.19 & -8.21 & & & \\
\hline 211 & 488.2 & 3.62 & -7.97 & & & \\
\hline 212.9 & 486.3 & 2.97 & -9.77 & & & \\
\hline 215.2 & 484 & 4.11 & -8.26 & & & \\
\hline 217.1 & 482.1 & 3.64 & -8.03 & & & \\
\hline 218.9 & 480.3 & 4.04 & -6.73 & & & \\
\hline 221 & 478.2 & 2.66 & -8.04 & & & \\
\hline 223.1 & 476.1 & 1.75 & -8.62 & & & \\
\hline 224.9 & 474.3 & 2.91 & -10.77 & & & \\
\hline 226.8 & 472.4 & 3.78 & -8.64 & & & \\
\hline 256.8 & 442.4 & 3.46 & -10.49 & & & \\
\hline 258.7 & 440.5 & 3.14 & -10.13 & & & \\
\hline 261 & 438.2 & 3.06 & -12.88 & & & \\
\hline 263 & 436.2 & 2.72 & -12.79 & & & \\
\hline 265.1 & 434.1 & 3.14 & -12.83 & & & \\
\hline 267.1 & 432.1 & 2.75 & -10.32 & & & \\
\hline 269.1 & 430.1 & 3.00 & -12.71 & & & \\
\hline 271.2 & 428 & 3.17 & -7.69 & & & \\
\hline 272.6 & 426.6 & 4.25 & -8.22 & & & \\
\hline 273.7 & 425.5 & 4.44 & -8.27 & & & \\
\hline 274.9 & 424.3 & 3.96 & -6.64 & & & \\
\hline 276.9 & 422.3 & 3.76 & -8.61 & & & \\
\hline 277.7 & 421.5 & 4.02 & -7.25 & -26.50 & 0.12 & \\
\hline 278.2 & 421 & 4.78 & -7.94 & & & \\
\hline 278.8 & 420.4 & 5.00 & -7.84 & & & \\
\hline 282.1 & 417.1 & 4.41 & -5.58 & & & \\
\hline 281.1 & 418.1 & 4.37 & -6.94 & & & \\
\hline 281.1 & 418.1 & 4.06 & -6.92 & & & \\
\hline 283.7 & 415.5 & 4.44 & -7.28 & & & \\
\hline 285.7 & 413.5 & 4.12 & -7.42 & & & \\
\hline 287.4 & 411.8 & 3.96 & -5.98 & & & \\
\hline 289.3 & 409.9 & & & -25.00 & 0.23 & \\
\hline 291.4 & 407.8 & 3.92 & -6.34 & & & \\
\hline 291.8 & 407.4 & 4.33 & -7.78 & -24.71 & 0.17 & \\
\hline 294.2 & 405 & 4.47 & -7.97 & -24.24 & -0.03 & \\
\hline 293.3 & 405.9 & 4.26 & -7.92 & & & \\
\hline 295.4 & 403.8 & 4.68 & -7.61 & & & \\
\hline 296.4 & 402.8 & 4.33 & -7.12 & & & \\
\hline 298.2 & 401 & 4.27 & -6.72 & -24.58 & 0.36 & -16 \\
\hline 299.2 & 400 & 4.19 & -6.36 & & & \\
\hline 300.3 & 398.9 & 4.47 & -7.93 & -22.73 & -0.04 & \\
\hline 301.3 & 397.9 & & & -26.66 & 0.21 & -32.5 \\
\hline
\end{tabular}




\begin{tabular}{|c|c|c|}
\hline Sample- A series & Sample -B series & $\mathrm{Fm} / \mathrm{Mb}$ \\
\hline 10RAT-DT111A91 & & Jago \\
\hline 10RAT-DT111A92 & & Jago \\
\hline 10RAT-DT111A93 & & Jago \\
\hline 10RAT-DT111A94 & & Jago \\
\hline 10RAT-DT111A95 & 10RAT-DT111B11 & Jago \\
\hline 10RAT-DT111A96 & & Jago \\
\hline 10RAT-DT111A97 & 10RAT-DT111B12 & Jago \\
\hline 10RAT-DT111A98 & & Jago \\
\hline 10RAT-DT111A99 & & Jago \\
\hline 10RAT-DT111A100 & 10RAT-DT111B13 & Jago \\
\hline 10RAT-DT111A101 & & Jago \\
\hline 10RAT-DT111A102 & & Jago \\
\hline 10RAT-DT111A103 & 10RAT-DT111B14 & Jago \\
\hline 10RAT-DT111A104 & & Jago \\
\hline 10RAT-DT111A105 & 10RAT-DT111B15 & Jago \\
\hline 10RAT-DT111A106 & & Jago \\
\hline 10RAT-DT111A107 & 10RAT-DT111B16 & Jago \\
\hline 10RAT-DT111A108 & & Jago \\
\hline 10RAT-DT111A109 & 10RAT-DT111B17 & Jago \\
\hline 10RAT-DT111A110 & & Jago \\
\hline 10RAT-DT111A111 & & Jago \\
\hline 10RAT-DT111A112 & & Jago \\
\hline 10RAT-DT111A113 & 10RAT-DT111B18 & Jago \\
\hline 10RAT-DT111A114 & & Jago \\
\hline 10RAT-DT111A115 & 10RAT-DT111B19 & Jago \\
\hline 10RAT-DT111A116 & & Jago \\
\hline 10RAT-DT111A117 & & Jago \\
\hline 10RAT-DT111A118 & & Jago \\
\hline 10RAT-DT111A119 & 10RAT-DT111B20 & Jago \\
\hline 10RAT-DT111A120 & & Jago \\
\hline 10RAT-DT111A121 & & Jago \\
\hline 10RAT-DT111A122 & & Jago \\
\hline 10RAT-DT111A123 & 10RAT-DT111B21 & Jago \\
\hline 10RAT-DT111A124 & & Jago \\
\hline 10RAT-DT111A125 & & Jago \\
\hline 10RAT-DT111A126 & 10RAT-DT111B22 & Jago \\
\hline 10RAT-DT111A127 & & Jago \\
\hline 10RAT-DT111A128 & 10RAT-DT111B23 & Jago \\
\hline 10RAT-DT111A129 & & Jago \\
\hline 10RAT-DT111A130 & & Jago \\
\hline 10RAT-DT111A131 & 10RAT-DT111B24 & Jago \\
\hline 10RAT-DT111A132 & 10RAT-DT111B25 & Jago \\
\hline 10RAT-DT111A133 & & Jago \\
\hline 10RAT-DT111A134 & 10RAT-DT111B26 & Jago \\
\hline 10RAT-DT111A135 & & Jago \\
\hline 10RAT-DT111A136 & 10RAT-DT111B27 & Jago \\
\hline 10RAT-DT111A138 & 10RAT-DT111B28 & Jago \\
\hline 10RAT-DT111A139 & & Jago \\
\hline 10RAT-DT111A140 & 10RAT-DT111B29 & Jago \\
\hline 10RAT-DT111A141 & & Jago \\
\hline 10RAT-DT111A142 & 10RAT-DT111B30 & Jago \\
\hline 10RAT-DT111A143 & & Jago \\
\hline 10RAT-DT111A144 & 10RAT-DT111B31 & Jago \\
\hline 10RAT-DT111A145 & & Jago \\
\hline 10RAT-DT111A146 & 10RAT-DT111B32 & Jago \\
\hline 10RAT-DT111A147 & 10RAT-DT111B33 & Jago \\
\hline
\end{tabular}

\begin{tabular}{|c|c|c|c|c|c|c|}
\hline m & $\begin{array}{c}\mathrm{m} \\
\text { (base) }\end{array}$ & $\delta^{13} \mathrm{C}_{\mathrm{carb}}$ & $\delta^{18} \mathrm{O}$ & $\delta^{13} C_{\text {ora }}$ & TOC & $\delta^{34} S$ \\
\hline 304.4 & 394.8 & 3.79 & -7.97 & & & \\
\hline 305.8 & 393.4 & 3.77 & -7.58 & & & \\
\hline 307.7 & 391.5 & 3.78 & -7.91 & & & \\
\hline 309.5 & 389.7 & 5.73 & -8.46 & & & \\
\hline 310.5 & 388.7 & 5.45 & -8.13 & -23.32 & 0.11 & \\
\hline 311.5 & 387.7 & 4.80 & -8.46 & & & \\
\hline 312.8 & 386.4 & 4.70 & -8.17 & -23.54 & -0.02 & -29 \\
\hline 313.5 & 385.7 & 5.94 & -8.22 & & & \\
\hline 315.5 & 383.7 & 4.98 & -7.58 & & & \\
\hline 316.1 & 383.1 & 5.23 & -5.29 & -28.12 & 0.23 & \\
\hline 316.5 & 382.7 & 5.54 & -7.91 & & & \\
\hline 317.5 & 381.7 & 5.54 & -7.99 & & & \\
\hline 319.3 & 379.9 & 5.20 & -4.95 & -23.34 & 0.11 & \\
\hline 319.5 & 379.7 & 4.94 & -7.06 & & & \\
\hline 320.6 & 378.6 & 4.64 & -7.66 & -25.09 & -0.01 & \\
\hline 321.4 & 377.8 & 4.73 & -8.42 & & & \\
\hline 321.8 & 377.4 & 4.22 & -4.60 & -25.09 & 0.19 & -33.6 \\
\hline 323.6 & 375.6 & 3.48 & -8.79 & & & \\
\hline 324.6 & 374.6 & 2.61 & -8.85 & -23.35 & 0.23 & \\
\hline 328.1 & 371.1 & 3.24 & -9.09 & & & \\
\hline 330.3 & 368.9 & 2.93 & -7.03 & & & \\
\hline 332.2 & 367 & 3.02 & -8.41 & & & \\
\hline 332.8 & 366.4 & 3.65 & -8.59 & -26.76 & 0.18 & -31.9 \\
\hline 334.2 & 365 & 3.79 & -8.02 & & & \\
\hline 334.9 & 364.3 & 3.97 & -9.02 & -22.19 & 0.28 & \\
\hline 336.3 & 362.9 & 3.77 & -8.60 & & & \\
\hline 338.2 & 361 & 2.71 & -8.85 & & & \\
\hline 339.3 & 359.9 & 2.82 & -8.21 & & & \\
\hline 340.1 & 359.1 & 3.25 & -8.27 & -24.97 & -0.02 & \\
\hline 341.2 & 358 & 3.30 & -8.62 & & & \\
\hline 342.4 & 356.8 & 2.74 & -7.68 & & & \\
\hline 343.7 & 355.5 & 3.74 & -8.90 & & & \\
\hline 344.4 & 354.8 & 3.15 & -6.63 & -24.72 & 0.48 & -1.8 \\
\hline 345.4 & 353.8 & 3.92 & -9.13 & & & \\
\hline 346.2 & 353 & 4.27 & -9.02 & & & \\
\hline 348.4 & 350.8 & 5.04 & -8.63 & -26.10 & 0.01 & \\
\hline 348.7 & 350.5 & 5.36 & -8.05 & & & \\
\hline 349.3 & 349.9 & 5.57 & -7.55 & -27.28 & 0.12 & \\
\hline 350.5 & 348.7 & 4.71 & -7.35 & & & \\
\hline 352.4 & 346.8 & 5.61 & -7.56 & & & \\
\hline 352.7 & 346.5 & 5.17 & -7.61 & -25.38 & 2.81 & -1.2 \\
\hline 354.2 & 345 & 5.32 & -7.82 & -27.42 & 0.31 & \\
\hline 354.5 & 344.7 & 5.89 & -7.50 & & & \\
\hline 355.7 & 343.5 & 5.94 & -7.46 & -26.99 & 0.26 & -11.3 \\
\hline 356.8 & 342.4 & 5.75 & -7.87 & & & \\
\hline 358.1 & 341.1 & 5.63 & -7.69 & -26.09 & 0.14 & \\
\hline 360 & 339.2 & 5.66 & -7.67 & -25.44 & 0.50 & -19.2 \\
\hline 361 & 338.2 & 5.76 & -7.76 & & & \\
\hline 362 & 337.2 & 5.80 & -7.87 & & & \\
\hline 363.2 & 336 & & & & & \\
\hline 364.2 & 335 & & & -25.33 & 0.06 & \\
\hline 365.2 & 334 & & & & & \\
\hline 366.2 & 333 & & & -26.08 & 0.13 & \\
\hline 367.3 & 331.9 & & & & & \\
\hline 367.9 & 331.3 & & & -25.28 & 0.34 & -31.5 \\
\hline 368.9 & 330.3 & & & -24.83 & 0.39 & \\
\hline
\end{tabular}




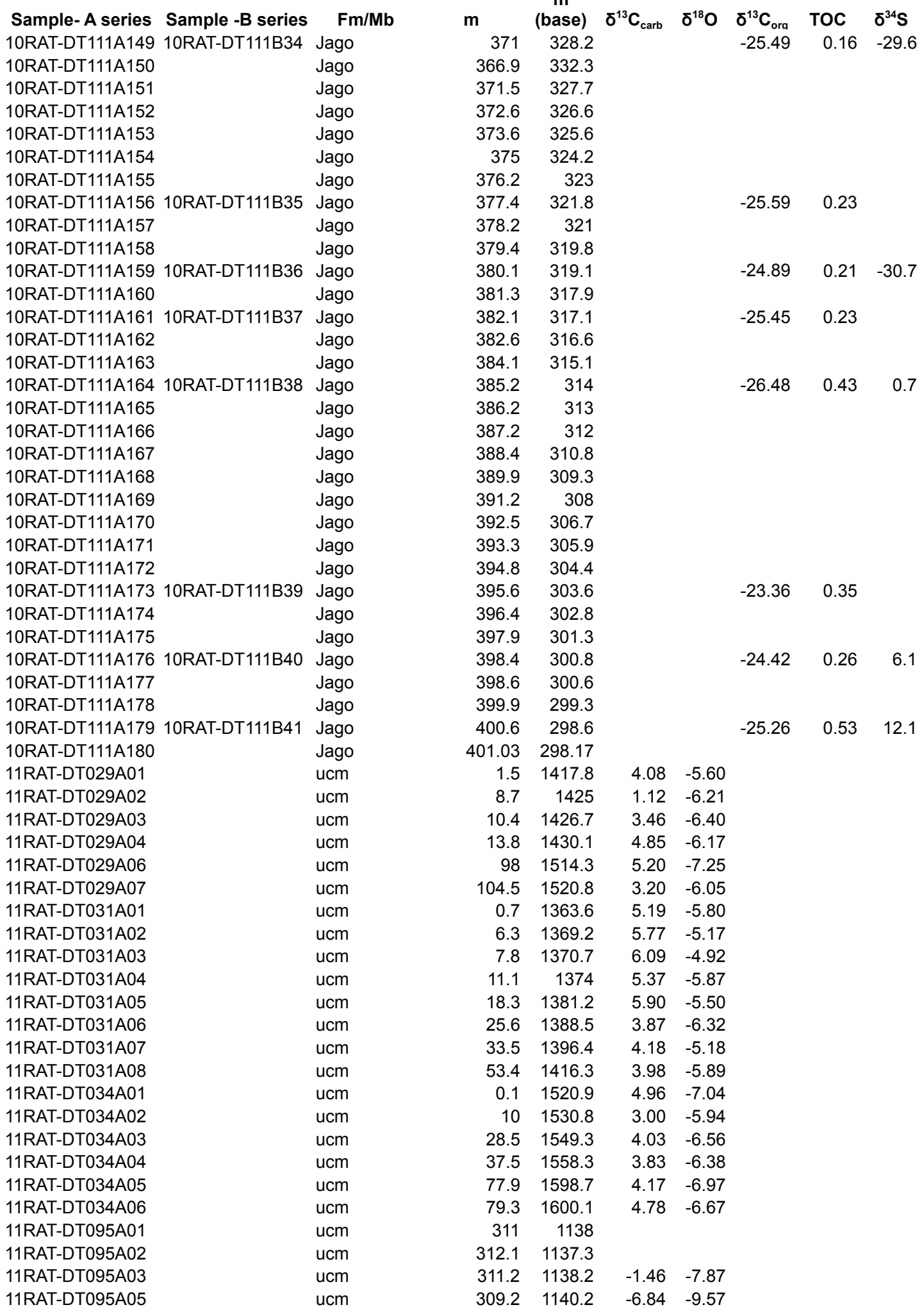




\begin{tabular}{|c|c|c|}
\hline Sample- A series & Sample -B series & $\mathrm{Fm} / \mathrm{Mb}$ \\
\hline 11RAT-DT095A07 & & $\mathrm{ucm}$ \\
\hline 11RAT-DT095A08 & & $\mathrm{ucm}$ \\
\hline 11RAT-DT095A09 & & $\mathrm{ucm}$ \\
\hline 11RAT-DT095A10 & & $\mathrm{ucm}$ \\
\hline 11RAT-DT095A11 & & $\mathrm{ucm}$ \\
\hline 11RAT-DT095A12 & & $\mathrm{ucm}$ \\
\hline 11RAT-DT095A13 & & $\mathrm{ucm}$ \\
\hline 11RAT-DT095A14 & & $\mathrm{ucm}$ \\
\hline 11RAT-DT095A15 & & $\mathrm{ucm}$ \\
\hline 11RAT-DT095A16 & & $\mathrm{ucm}$ \\
\hline 11RAT-DT095A17 & & $\mathrm{ucm}$ \\
\hline 11RAT-DT095A18 & & $\mathrm{ucm}$ \\
\hline 11RAT-DT095A19 & & $\mathrm{ucm}$ \\
\hline 11RAT-DT095A20 & & $\mathrm{ucm}$ \\
\hline 11RAT-DT095A21 & & $\mathrm{ucm}$ \\
\hline 11RAT-DT095A22 & & $\mathrm{ucm}$ \\
\hline 11RAT-DT095A23 & & $\mathrm{ucm}$ \\
\hline 11RAT-DT095A24 & & $\mathrm{ucm}$ \\
\hline 11RAT-DT095A25 & & $\mathrm{ucm}$ \\
\hline 11RAT-DT095A26 & & $\mathrm{ucm}$ \\
\hline 11RAT-DT095A27 & & $\mathrm{ucm}$ \\
\hline 11RAT-DT095A28 & & $\mathrm{ucm}$ \\
\hline 11RAT-DT095A29 & & $\mathrm{ucm}$ \\
\hline 11RAT-DT095A30 & & $\mathrm{ucm}$ \\
\hline 11RAT-DT095A31 & & $\mathrm{ucm}$ \\
\hline 11RAT-DT095A33 & & $\mathrm{ucm}$ \\
\hline 11RAT-DT095A34 & & $\mathrm{ucm}$ \\
\hline 11RAT-DT095A35 & & $\mathrm{ucm}$ \\
\hline 11RAT-DT095A36 & & $\mathrm{ucm}$ \\
\hline 11RAT-DT095A37 & & $\mathrm{ucm}$ \\
\hline 11RAT-DT095A38 & & $\mathrm{ucm}$ \\
\hline 11RAT-DT095A39 & & $\mathrm{ucm}$ \\
\hline 11RAT-DT095A40 & & $\mathrm{ucm}$ \\
\hline \multirow[t]{23}{*}{ 11RAT-DT095A41 } & & $\mathrm{ucm}$ \\
\hline & 11RAT-DT095B01 & $\mathrm{ucm}$ \\
\hline & 11RAT-DT095B02 & $\mathrm{ucm}$ \\
\hline & 11RAT-DT095B03 & $\mathrm{ucm}$ \\
\hline & 11RAT-DT095B04 & $\mathrm{ucm}$ \\
\hline & 11RAT-DT095B05 & $\mathrm{ucm}$ \\
\hline & 11RAT-DT095B06 & $\mathrm{ucm}$ \\
\hline & 11RAT-DT095B07 & $\mathrm{ucm}$ \\
\hline & 11RAT-DT095B08 & $\mathrm{ucm}$ \\
\hline & 11RAT-DT095B09 & $\mathrm{ucm}$ \\
\hline & 11RAT-DT095B10 & $\mathrm{ucm}$ \\
\hline & 11RAT-DT095B11 & $\mathrm{ucm}$ \\
\hline & 11RAT-DT095B12 & $\mathrm{ucm}$ \\
\hline & 11RAT-DT095B13 & $\mathrm{ucm}$ \\
\hline & 11RAT-DT095B14 & $\mathrm{ucm}$ \\
\hline & 11RAT-DT095B15 & $\mathrm{ucm}$ \\
\hline & 11RAT-DT095B16 & $\mathrm{ucm}$ \\
\hline & 11RAT-DT095B17 & $\mathrm{ucm}$ \\
\hline & 11RAT-DT095B18 & $\mathrm{ucm}$ \\
\hline & 11RAT-DT095B19 & $\mathrm{ucm}$ \\
\hline & 11RAT-DT095B20 & $\mathrm{ucm}$ \\
\hline & 11RAT-DT095B21 & $\mathrm{ucm}$ \\
\hline & 11RAT-DT095B22 & $\mathrm{ucm}$ \\
\hline
\end{tabular}

\begin{tabular}{|c|c|c|c|c|c|c|}
\hline m & (base) & $\delta^{13} C_{\text {carb }}$ & $\delta^{18} \mathrm{O}$ & $\delta^{13} C_{\text {ora }}$ & TOC & $\delta^{34} S$ \\
\hline 306.4 & 1143 & -7.78 & -9.02 & & & \\
\hline 305.2 & 1144.2 & -8.59 & -9.36 & & & \\
\hline 304.2 & 1145.2 & & & & & \\
\hline 303.3 & 1146.1 & -9.64 & -9.11 & & & \\
\hline 302.2 & 1147.2 & & & & & \\
\hline 300.8 & 1148.6 & -8.76 & -8.86 & & & \\
\hline 299.8 & 1149.6 & -10.82 & -8.89 & & & \\
\hline 298.5 & 1150.9 & -8.56 & -9.25 & & & \\
\hline 297.5 & 1151.9 & -10.17 & -9.37 & & & \\
\hline 296.8 & 1152.6 & -9.55 & -9.47 & & & \\
\hline 295.6 & 1153.8 & -4.50 & -8.66 & & & \\
\hline 294.6 & 1154.8 & -5.47 & -8.82 & & & \\
\hline 293 & 1156.4 & -14.31 & -8.89 & & & \\
\hline 292.1 & 1157.3 & -6.99 & -9.02 & & & \\
\hline 290.5 & 1158.9 & -8.47 & -9.45 & & & \\
\hline 289.5 & 1159.9 & -9.15 & -9.23 & & & \\
\hline 288.5 & 1160.9 & -7.52 & -8.85 & & & \\
\hline 287.3 & 1162.1 & -7.28 & -8.91 & & & \\
\hline 285.9 & 1163.5 & -8.03 & -9.04 & & & \\
\hline 285.5 & 1163.9 & -8.35 & -9.02 & & & \\
\hline 284.2 & 1165.2 & -6.75 & -9.37 & & & \\
\hline 282.9 & 1166.5 & -7.05 & -9.44 & & & \\
\hline 282 & 1167.4 & -6.38 & -10.14 & & & \\
\hline 281 & 1168.4 & & & & & \\
\hline 280 & 1169.4 & -6.88 & -9.17 & & & \\
\hline 278.1 & 1171.3 & -4.49 & -9.02 & & & \\
\hline 276.9 & 1172.5 & -5.73 & -9.88 & & & \\
\hline 275.6 & 1173.8 & -5.05 & -9.03 & & & \\
\hline 274.1 & 1175.3 & & & & & \\
\hline 272.7 & 1176.7 & -5.12 & -8.51 & & & \\
\hline 271.5 & 1177.9 & -4.80 & -12.35 & & & \\
\hline 270.6 & 1178.8 & & & & & \\
\hline 269.5 & 1179.9 & & & & & \\
\hline 267.5 & 1181.9 & & & & & \\
\hline 311.9 & 1138.9 & & & -31.57 & 0.89 & 7.6 \\
\hline 310.4 & 1140.4 & & & -31.01 & 0.63 & \\
\hline 309.6 & 1141.2 & & & -32.70 & 0.52 & \\
\hline 308.4 & 1142.4 & & & -34.11 & 8.48 & -23.82 \\
\hline 307.2 & 1143.6 & & & -33.72 & 6.96 & \\
\hline 305.7 & 1145.1 & & & -33.52 & 6.87 & -31.10 \\
\hline 304.4 & 1146.4 & & & -33.60 & 5.12 & -25.75 \\
\hline 303.7 & 1147.1 & & & -33.76 & 5.53 & -27.57 \\
\hline 302.1 & 1148.7 & & & -34.11 & 9.95 & -25.09 \\
\hline 301 & 1149.8 & & & -33.88 & 3.67 & -24.34 \\
\hline 300 & 1150.8 & & & -34.15 & 4.21 & -20.08 \\
\hline 299.1 & 1151.7 & & & -34.21 & 6.55 & -22.51 \\
\hline 297.5 & 1153.3 & & & -34.06 & 3.49 & -21.25 \\
\hline 296.5 & 1154.3 & & & -33.36 & 12.53 & -19.69 \\
\hline 295.3 & 1155.5 & & & -32.05 & 1.34 & -22.03 \\
\hline 294.2 & 1156.6 & & & -33.33 & 2.62 & -18.16 \\
\hline 293.2 & 1157.6 & & & -32.93 & 7.15 & -19.39 \\
\hline 292.1 & 1158.7 & & & -33.10 & 4.55 & -17.25 \\
\hline 290.6 & 1160.2 & & & -33.08 & 5.87 & -12.45 \\
\hline 289.5 & 1161.3 & & & -32.44 & 8.00 & -15.70 \\
\hline 288.4 & 1162.4 & & & -32.31 & 11.83 & -17.66 \\
\hline 287.5 & 1163.3 & & & -32.52 & 4.01 & -17.70 \\
\hline
\end{tabular}




\begin{tabular}{|c|c|c|c|c|c|c|c|c|c|}
\hline \multirow[t]{16}{*}{ Sample- A series } & Sample -B series & $\mathrm{Fm} / \mathrm{Mb}$ & m & $\begin{array}{c}m \\
\text { (base) }\end{array}$ & $\delta^{13} C_{\text {carb }}$ & $\delta^{18} O$ & $\delta^{13} C_{\text {ora }}$ & TOC & $\delta^{34} S$ \\
\hline & 11RAT-DT095B24 & $\mathrm{ucm}$ & 285.5 & 1165.3 & & & -31.94 & 2.30 & -14.91 \\
\hline & 11RAT-DT095B25 & $\mathrm{ucm}$ & 284.4 & 1166.4 & & & -32.03 & 1.59 & -7.18 \\
\hline & 11RAT-DT095B26 & $\mathrm{ucm}$ & 283.4 & 1167.4 & & & -31.32 & 9.15 & -12.95 \\
\hline & 11RAT-DT095B27 & $\mathrm{ucm}$ & 282.4 & 1168.4 & & & -30.87 & 4.12 & -16.49 \\
\hline & 11RAT-DT095B28 & $\mathrm{ucm}$ & 281.4 & 1169.4 & & & -30.99 & 8.38 & -13.66 \\
\hline & 11RAT-DT095B29 & $\mathrm{ucm}$ & 280.3 & 1170.5 & & & -31.18 & 8.32 & -4.87 \\
\hline & 11RAT-DT095B30 & $\mathrm{ucm}$ & 278.8 & 1172 & & & -30.98 & 6.69 & -3.57 \\
\hline & 11RAT-DT095B31 & $\mathrm{ucm}$ & 278.1 & 1172.7 & & & -30.35 & 8.40 & -0.59 \\
\hline & 11RAT-DT095B32 & $\mathrm{ucm}$ & 276.8 & 1174 & & & -30.05 & 6.47 & -5.47 \\
\hline & 11RAT-DT095B33 & $\mathrm{ucm}$ & 275.8 & 1175 & & & -29.58 & 3.81 & -9.46 \\
\hline & 11RAT-DT095B34 & $\mathrm{ucm}$ & 274.2 & 1176.6 & & & -29.34 & 6.36 & -6.32 \\
\hline & 11RAT-DT095B35 & $\mathrm{ucm}$ & 272.6 & 1178.2 & & & -29.20 & 2.29 & -9.40 \\
\hline & 11RAT-DT095B36 & $\mathrm{ucm}$ & 271.4 & 1179.4 & & & -29.01 & 8.12 & -10.35 \\
\hline & 11RAT-DT095B37 & $\mathrm{ucm}$ & 270.5 & 1180.3 & & & -28.99 & 7.64 & -7.88 \\
\hline & 11RAT-DT095B38 & ucm & 269.4 & 1181.4 & & & -28.64 & 0.20 & \\
\hline 11RAT-DT127A02 & & Jago & 10 & 260.7 & 2.26 & -11.96 & & & \\
\hline 11RAT-DT127A03 & & Jago & 14.5 & 264.2 & 3.38 & -10.23 & & & \\
\hline 11RAT-DT130A01 & & $\mathrm{ucm}$ & 0 & 1600.1 & & & -24.71 & 0.57 & -3.3 \\
\hline 11RAT-DT130A02 & & $\mathrm{ucm}$ & 0.1 & 1600.2 & & & -24.51 & 0.24 & \\
\hline 11RAT-DT130A03 & & $\mathrm{ucm}$ & 0.3 & 1600.4 & & & -24.85 & -0.04 & \\
\hline 11RAT-DT130A04 & & $\mathrm{ucm}$ & 0.45 & 1600.55 & & & -25.11 & 0.40 & \\
\hline 11RAT-DT130A05 & & $\mathrm{ucm}$ & 0.55 & 1600.65 & & & -25.51 & 0.33 & \\
\hline 11RAT-DT130A06 & & $\mathrm{ucm}$ & 0.7 & 1600.8 & & & -24.92 & 0.18 & \\
\hline 11RAT-DT130A07 & & $\mathrm{ucm}$ & 0.8 & 1600.9 & & & -25.12 & 0.08 & \\
\hline 11RAT-DT130A08 & & $\mathrm{ucm}$ & 0.9 & 1601 & & & -26.18 & 0.45 & 0 \\
\hline 11RAT-DT130A09 & & $\mathrm{ucm}$ & 0.9 & 1601 & & & -25.33 & 0.07 & \\
\hline 11RAT-DT130A10 & & $\mathrm{ucm}$ & 1 & 1601.1 & & & -25.68 & 0.25 & \\
\hline 11RAT-DT130A11 & & $\mathrm{ucm}$ & 1.05 & 1601.15 & & & -26.00 & 0.50 & 4.3 \\
\hline 11RAT-DT130A12 & & $\mathrm{ucm}$ & 1.25 & 1601.35 & & & -26.07 & 1.20 & 8.1 \\
\hline 11RAT-DT130A13 & & $\mathrm{ucm}$ & 1.3 & 1601.4 & & & -23.51 & 0.22 & \\
\hline 11RAT-DT130A14 & & $\mathrm{ucm}$ & 1.4 & 1601.5 & & & -23.95 & 0.28 & \\
\hline 11RAT-DT130A15 & & $\mathrm{ucm}$ & 1.5 & 1601.6 & & & -23.87 & 0.14 & \\
\hline 11RAT-DT130A16 & & $\mathrm{ucm}$ & 1.7 & 1601.8 & & & -22.99 & 0.08 & \\
\hline 11RAT-DT130A17 & & $\mathrm{ucm}$ & 1.75 & 1601.85 & & & & & \\
\hline 11RAT-DT130A18 & & $\mathrm{ucm}$ & 2 & 1602.1 & & & & & \\
\hline 11RAT-DT130A19 & & $\mathrm{ucm}$ & 2.15 & 1602.25 & & & & & \\
\hline 11RAT-DT130A20 & & $\mathrm{ucm}$ & 0 & 1600.1 & & & & & \\
\hline 11RAT-DT130A21 & & $\mathrm{ucm}$ & 0 & 1600.1 & & & & & \\
\hline 11RAT-DT130A22 & & $\mathrm{ucm}$ & 1.25 & 1601.35 & & & & & \\
\hline 11RAT-DT147A01 & & Jago & 1.5 & 270.7 & 4.15 & -9.19 & & & \\
\hline 11RAT-DT147A02 & & Jago & 6.7 & 275.9 & 2.50 & -9.03 & & & \\
\hline 11RAT-DT147A03 & & Jago & 22.1 & 291.3 & 2.68 & -9.14 & & & \\
\hline 11RAT-DT147A04 & & Jago & 23.8 & 293 & 2.54 & -9.07 & & & \\
\hline 11RAT-DT147A05 & & Jago & 26 & 295.2 & 2.60 & -8.55 & & & \\
\hline 11RAT-DT147A06 & & Jago & 27.5 & 296.7 & 3.90 & -8.39 & & & \\
\hline 11RAT-DT147A07 & & Jago & 28.6 & 297.8 & 3.75 & -8.46 & & & \\
\hline 11RAT-DT147A08 & & Jago & 30.6 & 299.8 & 4.54 & -3.68 & & & \\
\hline 11RAT-DT147A09 & & Jago & 32.1 & 301.3 & 4.72 & -3.21 & & & \\
\hline 11RAT-DT147A10 & & Jago & 33.8 & 303 & 4.53 & -6.09 & & & \\
\hline 11RAT-DT147A11 & & Jago & 35.1 & 304.3 & 4.13 & -3.10 & & & \\
\hline 11RAT-DT147A12 & & Jago & 36.1 & 305.3 & 3.65 & -3.93 & & & \\
\hline 11RAT-DT147A13 & & Jago & 38.1 & 307.3 & 4.03 & -5.87 & & & \\
\hline 11RAT-DT147A14 & & Jago & 39.6 & 308.8 & 4.35 & -7.65 & & & \\
\hline 11RAT-DT147A15 & & Jago & 42.2 & 311.4 & 3.34 & -7.40 & & & \\
\hline 11RAT-DT147A16 & & Jago & 44 & 313.2 & 4.56 & -2.95 & & & \\
\hline 11RAT-DT147A17 & & Jago & 45.8 & 315 & 4.78 & -3.64 & & & \\
\hline
\end{tabular}




\begin{tabular}{|c|c|c|c|c|c|c|c|c|}
\hline Sample- A series & Sample -B series & $\mathrm{Fm} / \mathrm{Mb}$ & m & (base) & $\delta^{13} C_{\text {carb }}$ & $\delta^{18} O$ & $\delta^{13} C_{\text {ora }}$ & TOC \\
\hline 11RAT-DT147A19 & & Jago & 52.5 & 321.7 & 4.82 & -3.69 & & \\
\hline 11RAT-DT147A20 & & Jago & 54.1 & 323.3 & 4.66 & -5.62 & & \\
\hline 11RAT-DT147A21 & & Jago & 55.6 & 324.8 & 4.46 & -1.08 & & \\
\hline 11RAT-DT147A22 & & Jago & 57.1 & 326.3 & 4.49 & -5.76 & & \\
\hline 11RAT-DT147A23 & & Jago & 60.7 & 329.9 & 5.22 & -3.49 & & \\
\hline 11RAT-DT147A25 & & Jago & 64.6 & 333.8 & 4.99 & -4.08 & & \\
\hline 11RAT-DT147A26 & & Jago & 67.6 & 336.8 & 5.04 & -5.71 & & \\
\hline 11RAT-DT147A27 & & Jago & 69.1 & 338.3 & & & & \\
\hline 11RAT-DT147A28 & & Jago & 72.1 & 341.3 & 5.19 & -5.61 & & \\
\hline 10RAT-GL028A1 & & bsm & 2 & 782.7 & & & -24.40 & \\
\hline 10RAT-GL028A2 & & bsm & 4 & 784.7 & & & -25.70 & \\
\hline 10RAT-GL028A3 & & bsm & 7.8 & 788.5 & & & -25.70 & \\
\hline 10RAT-GL028A4 & & bsm & 8.7 & 789.4 & & & -25.30 & \\
\hline 10RAT-GL028A5 & & bsm & 10.3 & 791 & & & -25.10 & \\
\hline 10RAT-GL028A6 & & bsm & 11.9 & 792.6 & & & -25.50 & \\
\hline 10RAT-GL028A7 & & bsm & 14 & 794.7 & & & -26.00 & \\
\hline 10RAT-GL028A8 & & bsm & 16.5 & 797.2 & & & -25.80 & \\
\hline 10RAT-GL028A9 & & bsm & 18.4 & 799.1 & & & -24.50 & \\
\hline 10RAT-GL028A10 & & bsm & 21 & 801.7 & & & -24.50 & \\
\hline 10RAT-GL028A11 & & bsm & 22 & 802.7 & & & -24.00 & \\
\hline 10RAT-GL028A12 & & bsm & 24 & 804.7 & & & -24.50 & \\
\hline 10RAT-GL028A13 & & bsm & 25.7 & 806.4 & & & -22.60 & \\
\hline 10RAT-GL028A14 & & bsm & 28 & 808.7 & & & -22.50 & \\
\hline 10RAT-GL028A15 & & bsm & 30 & 810.7 & & & -23.60 & \\
\hline 10RAT-GL028A16 & & bsm & 32 & 812.7 & & & -24.40 & \\
\hline 10RAT-GL028A17 & & bsm & 33 & 813.7 & & & -23.30 & \\
\hline 10RAT-GL028A18 & & bsm & 34.4 & 815.1 & & & -22.20 & \\
\hline 10RAT-GL028A19 & & bsm & 36.2 & 816.9 & & & -23.90 & \\
\hline 10RAT-GL028A20 & & bsm & 38 & 818.7 & & & -23.30 & \\
\hline 10RAT-GL028A21 & & bsm & 40 & 820.7 & & & -23.20 & \\
\hline 10RAT-GL028A22 & & bsm & 41.6 & 822.3 & & & -25.40 & \\
\hline 10RAT-GL028A23 & & bsm & 42 & 822.7 & & & -22.40 & \\
\hline 10RAT-GL028A24 & & bsm & 44 & 824.7 & & & -20.70 & \\
\hline 10RAT-GL028A25 & & bsm & 46 & 826.7 & & & -23.90 & \\
\hline 10RAT-GL028A26 & & bsm & 48 & 828.7 & & & -22.50 & \\
\hline 10RAT-GL028A27 & & bsm & 50 & 830.7 & & & -23.40 & \\
\hline 10RAT-GL028A28 & & bsm & 52 & 832.7 & & & -24.20 & \\
\hline 10RAT-GL028A29 & & bsm & 56 & 836.7 & & & -21.50 & \\
\hline 10RAT-GL028A30 & & bsm & 58 & 838.7 & & & -23.40 & \\
\hline 10RAT-GL028A31 & & bsm & 60 & 840.7 & & & -23.20 & \\
\hline 10RAT-GL028A32 & & bsm & 62 & 842.7 & & & -21.60 & \\
\hline 10RAT-GL028A33 & & bsm & 64 & 844.7 & & & -20.00 & \\
\hline 10RAT-GL028A34 & & bsm & 66 & 846.7 & & & -24.10 & \\
\hline 10RAT-GL028A35 & & bsm & 68 & 848.7 & & & -22.50 & \\
\hline 10RAT-GL028A36 & & bsm & 70 & 850.7 & & & -22.70 & \\
\hline 10RAT-GL028A37 & & bsm & 72 & 852.7 & & & -21.60 & \\
\hline 10RAT-GL028A38 & & bsm & 74 & 854.7 & & & -21.00 & \\
\hline 10RAT-GL028A39 & & bsm & 76 & 856.7 & & & -20.50 & \\
\hline 10RAT-GL028A40 & & bsm & 78 & 858.7 & & & -20.30 & \\
\hline 10RAT-GL028A41 & & bsm & 80 & 860.7 & & & -20.70 & \\
\hline 10RAT-GL028A42 & & bsm & 82.4 & 863.1 & & & -21.80 & \\
\hline 10RAT-GL028A44 & & bsm & 86 & 866.7 & & & -21.80 & \\
\hline 10RAT-GL028A45 & & bsm & 88 & 868.7 & & & -22.90 & \\
\hline 10RAT-GL028A47 & & bsm & 92 & 872.7 & & & -24.10 & \\
\hline 10RAT-GL028A48 & & bsm & 96 & 876.7 & & & -25.30 & \\
\hline 10RAT-GL028A49 & & bsm & 98 & 878.7 & & & -26.70 & \\
\hline
\end{tabular}




\begin{tabular}{|c|c|c|c|c|c|c|c|c|}
\hline Sample- A series & Sample -B series $\quad \mathrm{Fm} / \mathrm{Mb}$ & m & $\begin{array}{c}\mathrm{m} \\
\text { (base) }\end{array}$ & $\delta^{13} \mathrm{C}_{\text {carb }}$ & $\delta^{18} \mathrm{O}$ & $\delta^{13} \mathrm{C}_{\text {ora }}$ & TOC & $\delta^{34} \mathrm{~S}$ \\
\hline 10RAT-GL028A51 & bsm & 102 & 882.7 & & & -25.40 & & \\
\hline 10RAT-GL028A52 & bsm & 104 & 884.7 & & & -25.90 & & \\
\hline 10RAT-GL028A53 & bsm & 106 & 886.7 & & & -22.50 & & \\
\hline 10RAT-GL028A54 & bsm & 108 & 888.7 & & & -21.50 & & \\
\hline 10RAT-GL028A55 & bsm & 110 & 890.7 & & & -22.10 & & \\
\hline 10RAT-GL028A56 & bsm & 112 & 892.7 & & & -22.60 & & \\
\hline 10RAT-GL028A57 & bsm & 116 & 896.7 & & & -20.00 & & \\
\hline 10RAT-GL028A58 & bsm & 120 & 900.7 & & & -21.30 & & \\
\hline 10RAT-GL028A59 & bsm & 125 & 905.7 & & & -21.90 & & \\
\hline 10RAT-GL028A60 & bsm & 130 & 910.7 & & & -23.10 & & \\
\hline 10RAT-GL044A1 & bsm & 155 & 935.7 & & & -27.20 & & \\
\hline 10RAT-GL044A2 & bsm & 158 & 938.7 & & & -25.80 & & \\
\hline 10RAT-GL044A3 & bsm & 162 & 942.7 & & & -26.60 & & \\
\hline 10RAT-GL044A4 & bsm & 166 & 946.7 & & & -26.30 & & \\
\hline 10RAT-GL044A5 & bsm & 168 & 948.7 & & & -23.80 & & \\
\hline 10RAT-GL044A6 & bsm & 170 & 950.7 & & & -26.10 & & \\
\hline 10RAT-GL044A7 & bsm & 172 & 952.7 & & & -26.30 & & \\
\hline 10RAT-GL044A8 & bsm & 174 & 954.7 & & & -25.60 & & \\
\hline 10RAT-GL044A9 & bsm & 176 & 956.7 & & & -23.80 & & \\
\hline 10RAT-GL044A10 & bsm & 178 & 958.7 & & & -25.50 & & \\
\hline 10RAT-GL044A11 & bsm & 180 & 960.7 & & & -20.40 & & \\
\hline 10RAT-GL044A12 & bsm & 182 & 962.7 & & & -23.80 & & \\
\hline 10RAT-GL044A13 & bsm & 184 & 964.7 & & & -26.30 & & \\
\hline 10RAT-DT110-B01 & Ft. Collinson & 151.5 & 173.7 & & & -28.36 & 0.31 & -1.5 \\
\hline 10RAT-DT110-B02 & Ft. Collinson & 154.5 & 170.7 & & & -29.50 & 0.63 & 17.70 \\
\hline 10RAT-DT110-B03 & Ft. Collinson & 155.7 & 169.5 & 0.45 & -13.86 & -28.94 & 0.24 & \\
\hline 10RAT-DT110-B04 & Ft. Collinson & 157.5 & 167.7 & -0.25 & -14.73 & -28.23 & 0.07 & -15.9 \\
\hline 10RAT-DT110-B05 & Ft. Collinson & 162.4 & 162.8 & -0.04 & -14.33 & -29.30 & 0.20 & \\
\hline 10RAT-DT110-B06 & Ft. Collinson & 163.7 & 161.5 & -0.07 & -13.00 & -30.69 & 0.21 & \\
\hline 10RAT-DT110-B07 & Ft. Collinson & 167 & 158.2 & -0.52 & -14.13 & -29.19 & 0.30 & -2.4 \\
\hline 10RAT-DT110-B07 & Ft. Collinson & 169.6 & 155.6 & -0.35 & -14.34 & -29.94 & 0.42 & \\
\hline 10RAT-DT110-B09 & Ft. Collinson & 140.4 & 184.8 & 0.87 & -15.50 & -28.66 & 0.48 & \\
\hline 10RAT-DT110-B10 & Ft. Collinson & 142.9 & 182.3 & -0.31 & -13.56 & -28.41 & 0.96 & -9 \\
\hline 10RAT-DT110-B11 & Ft. Collinson & 148.6 & 176.6 & 1.70 & -11.58 & -28.64 & 0.13 & \\
\hline 10RAT-DT110-B12 & Ft. Collinson & 149.9 & 175.3 & 3.29 & -11.05 & -27.73 & 0.25 & \\
\hline 10RAT-DT110-B13 & Ft. Collinson & 195.1 & 130.1 & 1.45 & -15.14 & -28.83 & 0.89 & 9.7 \\
\hline 10RAT-DT110-B14 & Ft. Collinson & 203.1 & 122.1 & 5.31 & -9.38 & -25.86 & 0.66 & 7.9 \\
\hline 10RAT-DT110-B15 & Boot Inlet & 211.3 & 113.9 & 5.05 & -8.58 & -28.36 & 0.50 & \\
\hline 10RAT-DT110-B16 & Boot Inlet & 218.5 & 106.7 & 3.66 & -4.00 & -24.58 & 0.03 & \\
\hline 10RAT-DT110-B18 & Boot Inlet & 234.2 & 91.0 & 4.99 & -6.07 & -25.77 & 0.38 & \\
\hline 10RAT-DT110-B19 & Boot Inlet & 235.5 & 89.7 & 4.79 & -6.14 & -25.10 & 0.24 & \\
\hline 10RAT-DT110-B20 & Boot Inlet & 240.2 & 85.0 & 5.42 & -5.96 & -26.53 & 0.13 & \\
\hline 10RAT-DT110-B21 & Boot Inlet & 246.9 & 78.3 & 4.86 & -7.50 & -26.08 & 0.42 & \\
\hline 10RAT-DT110-B22 & Boot Inlet & 249.8 & 75.4 & 4.61 & -8.95 & -26.15 & 0.17 & \\
\hline 10RAT-DT110-B23 & Boot Inlet & 254.6 & 70.6 & 4.62 & -9.00 & -26.16 & 0.69 & -6.2 \\
\hline 10RAT-DT110-B24 & Boot Inlet & 259.9 & 65.3 & 6.14 & -6.78 & -25.75 & 0.21 & \\
\hline 10RAT-DT110-B25 & Boot Inlet & 262.1 & 63.1 & 5.13 & -9.67 & -26.33 & 0.20 & \\
\hline 10RAT-DT110-B26 & Boot Inlet & 264.4 & 60.8 & 4.62 & -9.80 & -25.93 & 0.26 & \\
\hline 10RAT-DT110-B27 & Boot Inlet & 269.2 & 56.0 & 4.49 & -10.84 & -26.23 & 0.01 & \\
\hline 10RAT-DT110-B28 & Boot Inlet & 274.8 & 50.4 & 4.99 & -8.84 & -26.67 & 0.34 & \\
\hline 10RAT-DT110-B29 & Boot Inlet & 278.1 & 47.1 & 5.19 & -10.02 & -26.90 & 0.41 & 7.50 \\
\hline 10RAT-DT110-B30 & Boot Inlet & 283.3 & 41.9 & 5.64 & -7.91 & -25.89 & 0.14 & \\
\hline 10RAT-DT110-B31 & Boot Inlet & 284.5 & 40.7 & 4.79 & -8.77 & -26.26 & 0.44 & 9.30 \\
\hline 10RAT-DT110-B32 & Boot Inlet & 288.4 & 36.8 & 4.87 & -9.14 & -26.48 & 0.50 & \\
\hline 10RAT-DT110-B33 & Boot Inlet & 291.6 & 33.6 & 4.65 & -8.79 & -26.30 & 0.73 & 14.2 \\
\hline 10RAT-DT110-B34 & Boot Inlet & 254.5 & 70.7 & 4.66 & -8.54 & -26.30 & 0.53 & \\
\hline
\end{tabular}




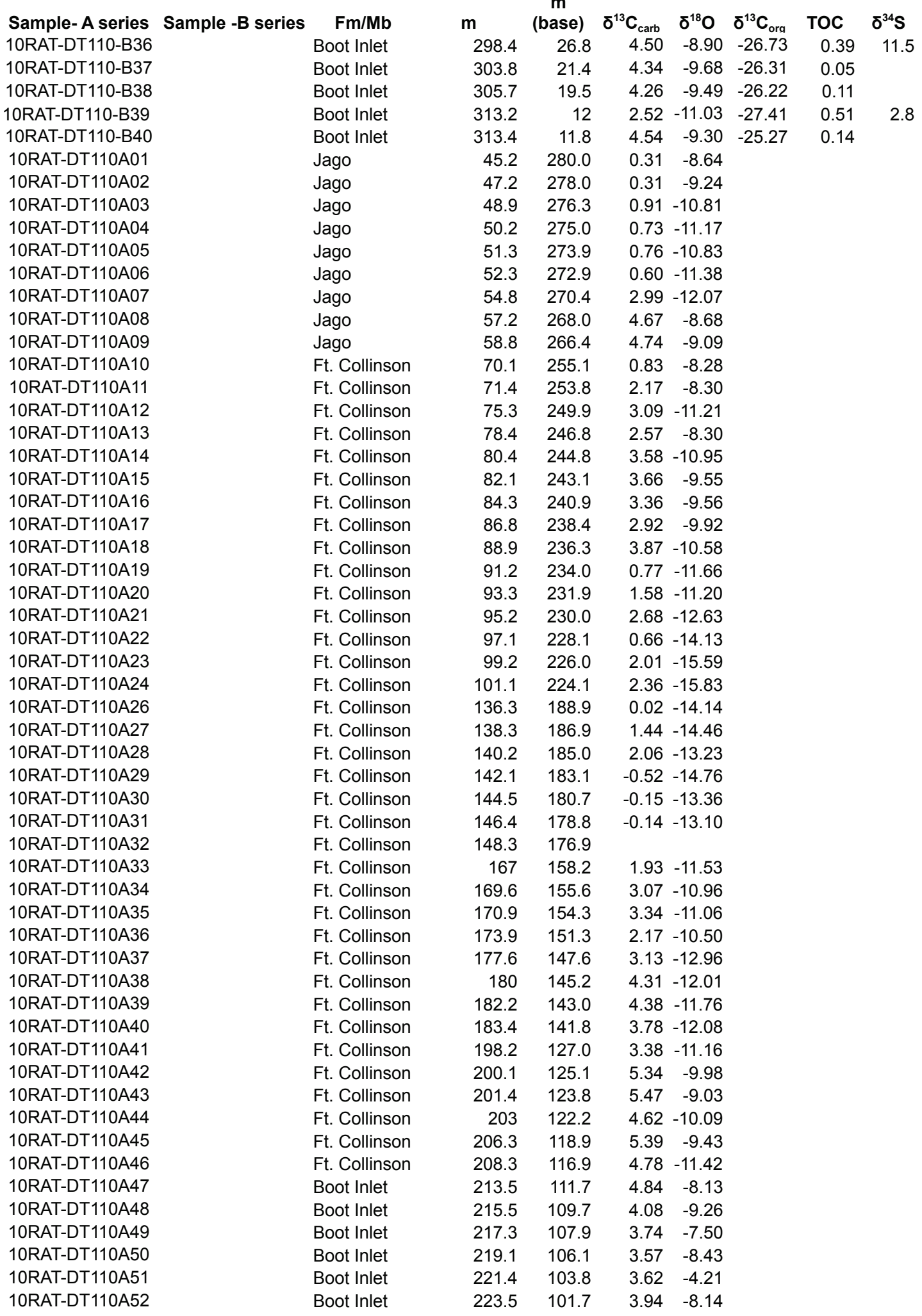




\begin{tabular}{|c|c|c|c|c|c|c|c|c|}
\hline Sample- A series & Sample -B series & Fm/Mb & m & (base) & $\delta^{13} C_{\text {carb }}$ & $\delta^{18} O$ & $\delta^{13} \mathrm{C}_{\text {ora }}$ & TOC \\
\hline 10RAT-DT110A54 & & Boot Inlet & 227.5 & 97.7 & 4.49 & -8.06 & & \\
\hline 10RAT-DT110A55 & & Boot Inlet & 229.5 & 95.7 & 4.75 & -7.55 & & \\
\hline 10RAT-DT110A56 & & Boot Inlet & 231.4 & 93.8 & 4.48 & -7.63 & & \\
\hline 10RAT-DT110A57 & & Boot Inlet & 233.4 & 91.8 & 4.63 & -7.83 & & \\
\hline 10RAT-DT110A58 & & Boot Inlet & 235.6 & 89.6 & 4.27 & -7.53 & & \\
\hline 10RAT-DT110A59 & & Boot Inlet & 237.5 & 87.7 & 4.30 & -7.57 & & \\
\hline 10RAT-DT110A60 & & Boot Inlet & 238.5 & 86.7 & & & & \\
\hline 10RAT-DT110A61 & & Boot Inlet & 239.5 & 85.7 & 4.86 & -6.32 & & \\
\hline 10RAT-DT110A62 & & Boot Inlet & 241.6 & 83.6 & 5.23 & -5.92 & & \\
\hline 10RAT-DT110A63 & & Boot Inlet & 243.6 & 81.6 & 3.53 & -8.11 & & \\
\hline 10RAT-DT110A64 & & Boot Inlet & 245.5 & 79.7 & 4.79 & -7.57 & & \\
\hline 10RAT-DT110A65 & & Boot Inlet & 247.8 & 77.4 & 4.94 & -7.89 & & \\
\hline 10RAT-DT110A66 & & Boot Inlet & 249.9 & 75.3 & 4.77 & -7.30 & & \\
\hline 10RAT-DT110A67 & & Boot Inlet & 252.2 & 73.0 & 4.58 & -8.78 & & \\
\hline 10RAT-DT110A68 & & Boot Inlet & 254.3 & 70.9 & 4.86 & -7.83 & & \\
\hline 10RAT-DT110A69 & & Boot Inlet & 256.3 & 68.9 & 5.07 & -8.26 & & \\
\hline 10RAT-DT110A70 & & Boot Inlet & 258 & 67.2 & 4.99 & -8.21 & & \\
\hline 10RAT-DT110A71 & & Boot Inlet & 260.3 & 64.9 & 5.04 & -7.93 & & \\
\hline 10RAT-DT110A74 & & Boot Inlet & 266.1 & 59.1 & 5.22 & -8.32 & & \\
\hline 10RAT-DT110A75 & & Boot Inlet & 268 & 57.2 & 5.42 & -8.35 & & \\
\hline 10RAT-DT110A76 & & Boot Inlet & 270.1 & 55.1 & 5.76 & -8.34 & & \\
\hline 10RAT-DT110A77 & & Boot Inlet & 272 & 53.2 & 5.85 & -8.61 & & \\
\hline 10RAT-DT110A78 & & Boot Inlet & 273.5 & 51.7 & 6.03 & -8.47 & & \\
\hline 10RAT-DT110A79 & & Boot Inlet & 275.2 & 50.0 & 4.89 & -8.52 & & \\
\hline 10RAT-DT110A80 & & Boot Inlet & 279.1 & 46.1 & 5.18 & -8.16 & & \\
\hline 10RAT-DT110A81 & & Boot Inlet & 281.1 & 44.1 & 5.56 & -8.40 & & \\
\hline 10RAT-DT110A82 & & Boot Inlet & 283.2 & 42.0 & 5.00 & -8.10 & & \\
\hline 10RAT-DT110A83 & & Boot Inlet & 285.1 & 40.1 & 4.52 & -8.83 & & \\
\hline 10RAT-DT110A84 & & Boot Inlet & 287.1 & 38.1 & 4.88 & -8.74 & & \\
\hline 10RAT-DT110A85 & & Boot Inlet & 289.1 & 36.1 & 4.51 & -8.68 & & \\
\hline 10RAT-DT110A86 & & Boot Inlet & 291.2 & 34.0 & 5.05 & -8.59 & & \\
\hline 10RAT-DT110A87 & & Boot Inlet & 293.1 & 32.1 & 4.20 & -8.76 & & \\
\hline 10RAT-DT110A88 & & Boot Inlet & 295.1 & 30.1 & 4.75 & -8.35 & & \\
\hline 10RAT-DT110A89 & & Boot Inlet & 297.2 & 28.0 & 4.60 & -8.73 & & \\
\hline 10RAT-DT110A90 & & Boot Inlet & 299.2 & 26.0 & 4.87 & -8.33 & & \\
\hline 10RAT-DT110A91 & & Boot Inlet & 301.2 & 24.0 & 4.34 & -8.36 & & \\
\hline 10RAT-DT110A92 & & Boot Inlet & 303.3 & 21.9 & 4.95 & -8.41 & & \\
\hline 10RAT-DT110A93 & & Boot Inlet & 305.2 & 20.0 & 4.24 & -9.32 & & \\
\hline 10RAT-DT110A94 & & Boot Inlet & 309.2 & 16.0 & 4.50 & -7.57 & & \\
\hline 10RAT-DT110A95 & & Boot Inlet & 311.3 & 13.9 & 3.78 & -9.56 & & \\
\hline 10RAT-DT110A96 & & Boot Inlet & 313.4 & 11.8 & 3.33 & -9.98 & & \\
\hline 10RAT-DT110A97 & & Boot Inlet & 315.3 & 9.9 & 3.52 & -9.74 & & \\
\hline 10RAT-DT110A98 & & Boot Inlet & 316.4 & 8.8 & 3.58 & -9.83 & & \\
\hline 10RAT-DT110A99 & & Boot Inlet & 318.3 & 6.9 & 3.65 & -9.83 & & \\
\hline 10RAT-DT110A100 & & Boot Inlet & 320.3 & 4.9 & 3.52 & -10.15 & & \\
\hline 10RAT-DT110A101 & & Boot Inlet & 322.2 & 3.0 & 3.44 & -11.07 & & \\
\hline 10RAT-DT110A102 & & Boot Inlet & 324.3 & 0.9 & 3.44 & -10.74 & & \\
\hline 10RAT-DT110A103 & & Boot Inlet & 325.2 & 0 & 3.36 & -10.80 & & \\
\hline 10RAT-DT110A104 & & Boot Inlet & 325.2 & 0 & 3.44 & -9.76 & & \\
\hline
\end{tabular}


Appendix 3. Trace element data. MDL - maximum detection limit.

\begin{tabular}{|c|c|c|c|c|c|c|c|c|c|c|c|}
\hline Sample- A series & $\mathrm{Fm} / \mathrm{Mb}$ & $\begin{array}{l}\quad \text { m } \\
\text { (measu } \\
\text { red) }\end{array}$ & $\begin{array}{l}\quad \text { m } \\
\text { Boot } \\
\text { Inlet) }\end{array}$ & $\begin{array}{l}\text { Unit } \\
\text { MDL }\end{array}$ & $\begin{array}{l}\text { Mo } \\
\text { PPM } \\
0.05\end{array}$ & $\begin{array}{l}\text { V } \\
\text { PPM } \\
\\
\\
\end{array}$ & $\begin{array}{l}\text { U } \\
\text { PPM } \\
0.1\end{array}$ & $\begin{array}{l}\text { Mn } \\
\text { PPM } \\
2\end{array}$ & $\begin{array}{l}\mathrm{Fe} \\
\% \\
0.0\end{array}$ & $\begin{array}{l}\mathrm{Mg} \\
\% \\
0\end{array}$ & $\begin{array}{l}\text { Al } \\
\% \\
0\end{array}$ \\
\hline 10RAT-DT027A11 & $\mathrm{Icm}$ & 53 & 709.7 & & 0.1 & 4 & 0.2 & 832 & 1.0 & 11 & 0.3 \\
\hline 10RAT-DT027A19 & $\mathrm{Icm}$ & 91.6 & 748.3 & & 0.1 & 7 & 0.2 & 771 & 0.8 & 12 & 0.3 \\
\hline 10RAT-DT030A7 & bsm & 18 & 798.7 & & 0.1 & 69 & 1.6 & 920 & 4.8 & 4.2 & 5.6 \\
\hline 10RAT-DT030A12 & bsm & 73.5 & 854.2 & & 6.8 & 60 & 1.4 & 657 & 15.8 & 0.6 & 3.5 \\
\hline 10RAT-DT057A3 & $\mathrm{ucm}$ & 7.8 & 1382.7 & & 0.1 & 3 & 2.1 & 48 & 0.1 & 0.3 & 0.3 \\
\hline 10RAT-DT058A9 & $\mathrm{scm}$ & 47.2 & 1022.1 & & 0.1 & 12 & 0.9 & 480 & 1.1 & 10 & 1.7 \\
\hline 10RAT-DT060A4 & $\mathrm{scm}$ & 17 & 1096.9 & & 0.1 & 2 & 0.2 & 285 & 0.3 & 12 & 0.2 \\
\hline 10RAT-DT060A23 & $\mathrm{scm}$ & 55.1 & 1135 & & 0.4 & 20 & 0.8 & 287 & 1.0 & 10 & 0.7 \\
\hline 10RAT-DT062A8 & $\mathrm{ucm}$ & 28.5 & 1243.4 & & 0.08 & 4 & 0.2 & 91 & 0.4 & 1.1 & 0.4 \\
\hline 10RAT-DT074A6 & $\mathrm{scm}$ & 26.4 & 991 & & 0.08 & 10 & 0.3 & 215 & 0.6 & 1 & 1.1 \\
\hline 10RAT-DT074A13 & $\mathrm{scm}$ & 72.8 & 1037.4 & & 0.05 & 5 & 0.4 & 107 & 0.3 & 2.7 & 0.6 \\
\hline 10RAT-DT111A11 & Minto & 36.6 & 662.6 & & 0.26 & 71 & 3.9 & 89 & 1.1 & 5.9 & 6.1 \\
\hline 10RAT-DT111A85 & Jago & 298.2 & 401 & & $<0.05$ & 15 & 1.6 & 206 & 0.7 & 3.3 & 1.8 \\
\hline 10RAT-DT111A97 & Jago & 312.8 & 386.4 & & 0.15 & 31 & 2.6 & 208 & 1.4 & 2.7 & 2.9 \\
\hline 10RAT-DT111A107 & Jago & 321.8 & 377.4 & & 0.2 & 22 & 1.7 & 483 & 1.7 & 2 & 2.3 \\
\hline 10RAT-DT111A113 & Jago & 332.8 & 366.4 & & 0.3 & 67 & 5.7 & 295 & 2.2 & 3.9 & 6.1 \\
\hline 10RAT-DT111A123 & Jago & 344.4 & 354.8 & & 0.09 & 17 & 2.2 & 311 & 0.8 & 2.8 & 1.5 \\
\hline 10RAT-DT111A131 & Jago & 352.7 & 346.5 & & 0.16 & 17 & 2.4 & 310 & 0.8 & 2.5 & 1.4 \\
\hline 10RAT-DT111A134 & Jago & 355.7 & 343.5 & & 0.3 & 67 & 3.3 & 258 & 3.1 & 2.9 & 5.8 \\
\hline 10RAT-DT111A138 & Jago & 360 & 339.2 & & 0.19 & 52 & 2.3 & 349 & 2.5 & 3 & 5.4 \\
\hline 10RAT-DT111A146 & Jago & 367.9 & 331.3 & & 0.23 & 53 & 2.9 & 298 & 2.1 & 2.6 & 4.9 \\
\hline 10RAT-DT111A149 & Jago & 371 & 328.2 & & 0.1 & 15 & 1.9 & 298 & 0.7 & 2.6 & 1.3 \\
\hline 10RAT-DT111A150 & Jago & 366.9 & 332.3 & & sample I & I.S. & I.S. & I.S. & I.S. & I.S. & I.S. \\
\hline 10RAT-DT & Jago & 380.1 & 319.1 & & 0.3 & 76 & 3 & 303 & 2.9 & 2.8 & 6.9 \\
\hline 10RAT-DT111A164 & Jago & 385.2 & 314 & & $<0.05$ & 8 & 1.2 & 198 & 0.2 & 0.6 & 0.5 \\
\hline 10RAT-DT111A176 & Jago & 398.4 & 300.8 & & 0.08 & 20 & 2.6 & 227 & 0.9 & 1.4 & 1.9 \\
\hline 10RAT-DT111A179 & Jago & 400.6 & 298.6 & & 0.17 & 72 & 5.5 & 186 & 1.8 & 2.5 & 6.9 \\
\hline 11RAT-DT095B01 & $\mathrm{ucm}$ & 311.9 & 1138.9 & & 0.2 & 70 & 0.4 & 353 & 3.0 & 12 & 2.6 \\
\hline 11RAT-DT095B04 & $\mathrm{ucm}$ & 308.4 & 1142.4 & & 47.6 & 1732 & 16 & 49 & 1.7 & 1.4 & 5.7 \\
\hline 11RAT-DT095B05 & $\mathrm{ucm}$ & 307.2 & 1143.6 & & 24.7 & 514 & 9.9 & 69 & 1.3 & 1.4 & 6.3 \\
\hline 11RAT-DT095B06 & $\mathrm{ucm}$ & 305.7 & 1145.1 & & 14.0 & 673 & 6.5 & 127 & 0.9 & 1.1 & 5.1 \\
\hline 11RAT-DT095B07 & $\mathrm{ucm}$ & 304.4 & 1146.4 & & 15.2 & 1084 & 8.7 & 63 & 1.7 & 1.4 & 8.2 \\
\hline 11RAT-DT095B08 & $\mathrm{ucm}$ & 303.7 & 1147.1 & & 61.3 & 1732 & 12 & 65 & 2.0 & 1.4 & 6.9 \\
\hline 11RAT-DT095B09 & $\mathrm{ucm}$ & 302.1 & 1148.7 & & 43.6 & 1511 & 11 & 42 & 1.7 & 1.4 & 5.6 \\
\hline 11RAT-DT095B10 & $\mathrm{ucm}$ & 301 & 1149.8 & & 41.8 & 1368 & 14 & 111 & 2.2 & 4.1 & 6.8 \\
\hline 11RAT-DT095B11 & $\mathrm{ucm}$ & 300 & 1150.8 & & 48.5 & 1991 & 18 & 123 & 2.0 & 2.5 & 7 \\
\hline 11RAT-DT095B12 & $\mathrm{ucm}$ & 299.1 & 1151.7 & & 92.5 & 2407 & 20 & 99 & 1.8 & 2.7 & 6.7 \\
\hline 11RAT-DT095B13 & $\mathrm{ucm}$ & 297.5 & 1153.3 & & 61.6 & 2087 & 7.7 & 193 & 1.9 & 3.5 & 5.9 \\
\hline 11RAT-DT095B14 & $\mathrm{ucm}$ & 296.5 & 1154.3 & & 51.0 & 2826 & 18 & 67 & 3.5 & 1.2 & 5.8 \\
\hline 11RAT-DT095B15 & $\mathrm{ucm}$ & 295.3 & 1155.5 & & 18.0 & 730 & 15 & 141 & 2.1 & 4.4 & 6.4 \\
\hline 11RAT-DT095B16 & $\mathrm{ucm}$ & 294.2 & 1156.6 & & 64.7 & 964 & 12 & 172 & 1.0 & 1.7 & 4.6 \\
\hline 11RAT-DT095B17 & $\mathrm{ucm}$ & 293.2 & 1157.6 & & 179.2 & 2578 & 14 & 89 & 1.8 & 3.1 & 6.9 \\
\hline 11RAT-DT095B18 & $\mathrm{ucm}$ & 292.1 & 1158.7 & & 27.7 & 346 & 16 & 142 & 1.1 & 1 & 5.1 \\
\hline 11RAT-DT095B19 & $\mathrm{ucm}$ & 290.6 & 1160.2 & & 63.9 & 695 & 9.9 & 88 & 1.1 & 1.2 & 5.8 \\
\hline 11RAT-DT095B20 & $\mathrm{ucm}$ & 289.5 & 1161.3 & & 76.5 & 1515 & 11 & 114 & 1.2 & 1.5 & 5.3 \\
\hline 11RAT-DT095B21 & $\mathrm{ucm}$ & 288.4 & 1162.4 & & 129.2 & 1572 & 18 & 46 & 1.2 & 1.1 & 5.4 \\
\hline 11RAT-DT095B22 & $\mathrm{ucm}$ & 287.5 & 1163.3 & & 54.1 & 1004 & 8.8 & 131 & 1.3 & 2.9 & 6.4 \\
\hline 11RAT-DT095B23 & $\mathrm{ucm}$ & 286.5 & 1164.3 & & 155.7 & 1272 & 14 & 102 & 2.4 & 1.9 & 6.1 \\
\hline 11RAT-DT095B24 & $\mathrm{ucm}$ & 285.5 & 1165.3 & & 29.5 & 491 & 5 & 165 & 1.1 & 3.5 & 5.3 \\
\hline 11RAT-DT095B25 & $\mathrm{ucm}$ & 284.4 & 1166.4 & & 8.9 & 335 & 5.2 & 239 & 1.8 & 4.5 & 4.5 \\
\hline 11RAT-DT095B26 & $\mathrm{ucm}$ & 283.4 & 1167.4 & & 21.7 & 799 & 10 & 69 & 1.4 & 1.5 & 6 \\
\hline 11RAT-DT095B27 & $\mathrm{ucm}$ & 282.4 & 1168.4 & & 27.1 & 701 & 12 & 143 & 1.2 & 4.1 & 6.5 \\
\hline 11RAT-DT095B28 & $\mathrm{ucm}$ & 281.4 & 1169.4 & & 22.3 & 873 & 14 & 109 & 1.1 & 2.1 & 6.3 \\
\hline 11RAT-DT095B29 & $\mathrm{ucm}$ & 280.3 & 1170.5 & & 33.2 & 496 & 9.4 & 124 & 0.9 & 1.4 & 5.4 \\
\hline 11RAT-DT095B30 & $\mathrm{ucm}$ & 278.8 & 1172 & & 11.9 & 189 & 8.8 & 211 & 1.5 & 3.1 & 5.6 \\
\hline
\end{tabular}




\begin{tabular}{|c|c|c|c|c|c|c|c|c|c|c|}
\hline Sample-A series & $\mathrm{Fm} / \mathrm{Mb}$ & m & m & Mo & $\mathbf{v}$ & U & Mn & $\mathrm{Fe}$ & $\mathrm{Mg}$ & Al \\
\hline 11RAT-DT095B32 & $\mathrm{ucm}$ & 276.8 & 1174 & 11.2 & 177 & 15 & 182 & 2.8 & 3 & 6 \\
\hline 11RAT-DT095B33 & $\mathrm{ucm}$ & 275.8 & 1175 & 5.2 & 97 & 9.7 & 169 & 1.2 & 2.3 & 4.2 \\
\hline 11RAT-DT095B34 & $\mathrm{ucm}$ & 274.2 & 1176.6 & 7.7 & 443 & 10 & 100 & 1.9 & 4.4 & 6.4 \\
\hline 11RAT-DT095B35 & ucm & 272.6 & 1178.2 & 2.6 & 123 & 6 & 220 & 1.5 & 7.2 & 3 \\
\hline 11RAT-DT095B36 & $\mathrm{ucm}$ & 271.4 & 1179.4 & 9.7 & 267 & 13 & 154 & 1.5 & 5.7 & 3.9 \\
\hline 11RAT-DT095B37 & $\mathrm{ucm}$ & 270.5 & 1180.3 & 5.9 & 275 & 12 & 167 & 2.8 & 7.2 & 5.9 \\
\hline 11RAT-DT095B38 & $\mathrm{ucm}$ & 269.4 & 1181.4 & 1.29 & 56 & 1.9 & 281 & 2.0 & 8.1 & 2.6 \\
\hline 11RAT-DT095B39 & $\mathrm{ucm}$ & 267.6 & 1183.2 & 0.31 & 318 & 9.2 & 97 & 2.2 & 6.4 & 6.7 \\
\hline 11RAT-DT130A01 & $\mathrm{ucm}$ & 0 & 1600.1 & 0.1 & $<1$ & $<0.1$ & 128 & 0.2 & 0.6 & 0.1 \\
\hline 11RAT-DT130A08 & $\mathrm{ucm}$ & 0.9 & 1601 & 0.3 & 35 & 1.4 & 108 & 1.1 & 11 & 2.6 \\
\hline 11RAT-DT130A11 & $\mathrm{ucm}$ & 1.05 & 1601.15 & 0.2 & 39 & 1.5 & 201 & 1.0 & 13 & 2.3 \\
\hline 11RAT-DT130A12 & $\mathrm{ucm}$ & 1.25 & 1601.35 & 0.1 & 9 & 0.6 & 206 & 0.6 & 11 & 0.8 \\
\hline 10RAT-DT110-B01 & Ft. Collinson & 151.5 & 173.7 & 0.9 & 109 & 3.2 & 69 & 2.9 & 1.8 & 7.3 \\
\hline 10RAT-DT110-B02 & Ft. Collinson & 154.5 & 170.7 & 0.1 & 25 & 1.2 & 114 & 0.5 & 0.7 & 2.4 \\
\hline 10RAT-DT110-B04 & Ft. Collinson & 157.5 & 167.7 & 0.2 & 26 & 0.8 & 120 & 3.4 & 1.5 & 4.9 \\
\hline 10RAT-DT110-B07 & Ft. Collinson & 167 & 158.2 & 0.3 & 49 & 2.1 & 134 & 1.9 & 1.3 & 5.8 \\
\hline 10RAT-DT110-B10 & Ft. Collinson & 142.9 & 182.3 & 0.7 & 118 & 7.8 & 150 & 2.2 & 1.5 & 8.1 \\
\hline 10RAT-DT110-B13 & Ft. Collinson & 195.1 & 130.1 & 0.3 & 61 & 3.1 & 150 & 2.9 & 0.9 & 5.5 \\
\hline 10RAT-DT110-B14 & Ft. Collinson & 203.1 & 122.1 & 0.3 & 74 & 2.8 & 83 & 1.7 & 1.5 & 7 \\
\hline 10RAT-DT110-B23 & Boot Inlet & 254.6 & 70.6 & 0.3 & 63 & 2.3 & 138 & 1.8 & 1.8 & 6 \\
\hline 10RAT-DT110-B29 & Boot Inlet & 278.1 & 47.1 & 0.1 & 47 & 1.7 & 130 & 1.4 & 1.3 & 4.4 \\
\hline 10RAT-DT110-B31 & Boot Inlet & 284.5 & 40.7 & 0.3 & 75 & 3 & 131 & 1.6 & 1.4 & 6.6 \\
\hline 10RAT-DT110-B33 & Boot Inlet & 291.6 & 33.6 & 0.3 & 75 & 3.1 & 133 & 2.1 & 1.9 & 6.9 \\
\hline 10RAT-DT110-B36 & Boot Inlet & 298.4 & 26.8 & 0.2 & 45 & 1.7 & 101 & 1.7 & 1 & 5.1 \\
\hline 10RAT-DT110-B39 & Boot Inlet & 313.2 & 12 & 0.14 & 29 & 1.4 & 159 & 0.9 & 1 & 3 \\
\hline GL028-01 & bsm & 2.0 & 523.0 & 0.23 & 82 & 2.0 & & & & \\
\hline GL028-02 & bsm & 6.9 & 527.9 & 0.28 & 121 & 2.2 & & & & \\
\hline GL028-03 & bsm & 7.8 & 528.8 & 0.28 & 149 & 2.3 & & & & \\
\hline GL028-04 & bsm & 8.7 & 529.7 & 0.11 & 116 & 1.8 & & & & \\
\hline GL028-06 & bsm & 11.9 & 532.9 & 0.19 & 114 & 2.2 & & & & \\
\hline GL028-07 & bsm & 14.0 & 535.0 & 0.39 & 148 & 2.2 & & & & \\
\hline GL028-08 & bsm & 16.5 & 537.5 & 0.33 & 133 & 2.9 & & & & \\
\hline GL028-09 & bsm & 18.0 & 539.0 & 0.18 & 73 & 2.1 & & & & \\
\hline GL028-10 & bsm & 18.4 & 539.4 & 0.23 & 96 & 2.2 & & & & \\
\hline GL028-11 & bsm & 21.0 & 542.0 & 0.15 & 143 & 2.3 & & & & \\
\hline GL028-13 & bsm & 24.0 & 545.0 & 0.39 & 90 & 2.2 & & & & \\
\hline GL028-14 & bsm & 25.7 & 546.7 & 1.66 & 134 & 4.1 & & & & \\
\hline GL028-15 & bsm & 28.0 & 549.0 & 0.14 & 95 & 1.9 & & & & \\
\hline GL028-18 & bsm & 33.0 & 554.0 & 1.98 & 110 & 3.3 & & & & \\
\hline GL028-19 & bsm & 34.4 & 555.4 & 0.32 & 126 & 2.4 & & & & \\
\hline GL028-20B & bsm & 36.9 & 557.9 & 0.53 & 147 & 2.4 & & & & \\
\hline GL028-21 & bsm & 38.0 & 559.0 & 0.37 & 145 & 2.6 & & & & \\
\hline GL028-22F & bsm & 40.0 & 561.0 & 0.25 & 141 & 2.8 & & & & \\
\hline GL028-24 & bsm & 42.0 & 563.0 & 0.45 & 83 & 1.3 & & & & \\
\hline GL028-25 & bsm & 44.0 & 565.0 & 1.92 & 135 & 6.9 & & & & \\
\hline GL028-26 & bsm & 46.0 & 567.0 & 0.49 & 126 & 3.6 & & & & \\
\hline GL028-28 & bsm & 50.0 & 571.0 & 1.87 & 132 & 3.7 & & & & \\
\hline GL028-29 & bsm & 52.0 & 573.0 & 0.16 & 84 & 2.3 & & & & \\
\hline GL028-31 & bsm & 56.0 & 577.0 & 0.39 & 142 & 3.0 & & & & \\
\hline GL028-34 & bsm & 62.0 & 583.0 & 1.67 & 114 & 5.6 & & & & \\
\hline GL028-36 & bsm & 66.0 & 587.0 & 0.23 & 92 & \#\# & & & & \\
\hline GL028-38 & bsm & 70.0 & 591.0 & 0.29 & 113 & 4.0 & & & & \\
\hline GL028-39 & bsm & 72.0 & 593.0 & 0.99 & 97 & 3.6 & & & & \\
\hline GL028-41 & bsm & 76.0 & 597.0 & 1.76 & 119 & 5.6 & & & & \\
\hline GL028-44F & bsm & 82.4 & 603.4 & 0.20 & 95 & 3.7 & & & & \\
\hline GL028-45 & bsm & 84.0 & 605.0 & 0.61 & 139 & 5.8 & & & & \\
\hline GL028-46 & bsm & 86.0 & 607.0 & 0.41 & 54 & 2.3 & & & & \\
\hline GL028-47 & bsm & 88.0 & 609.0 & 0.90 & 147 & 5.7 & & & & \\
\hline
\end{tabular}




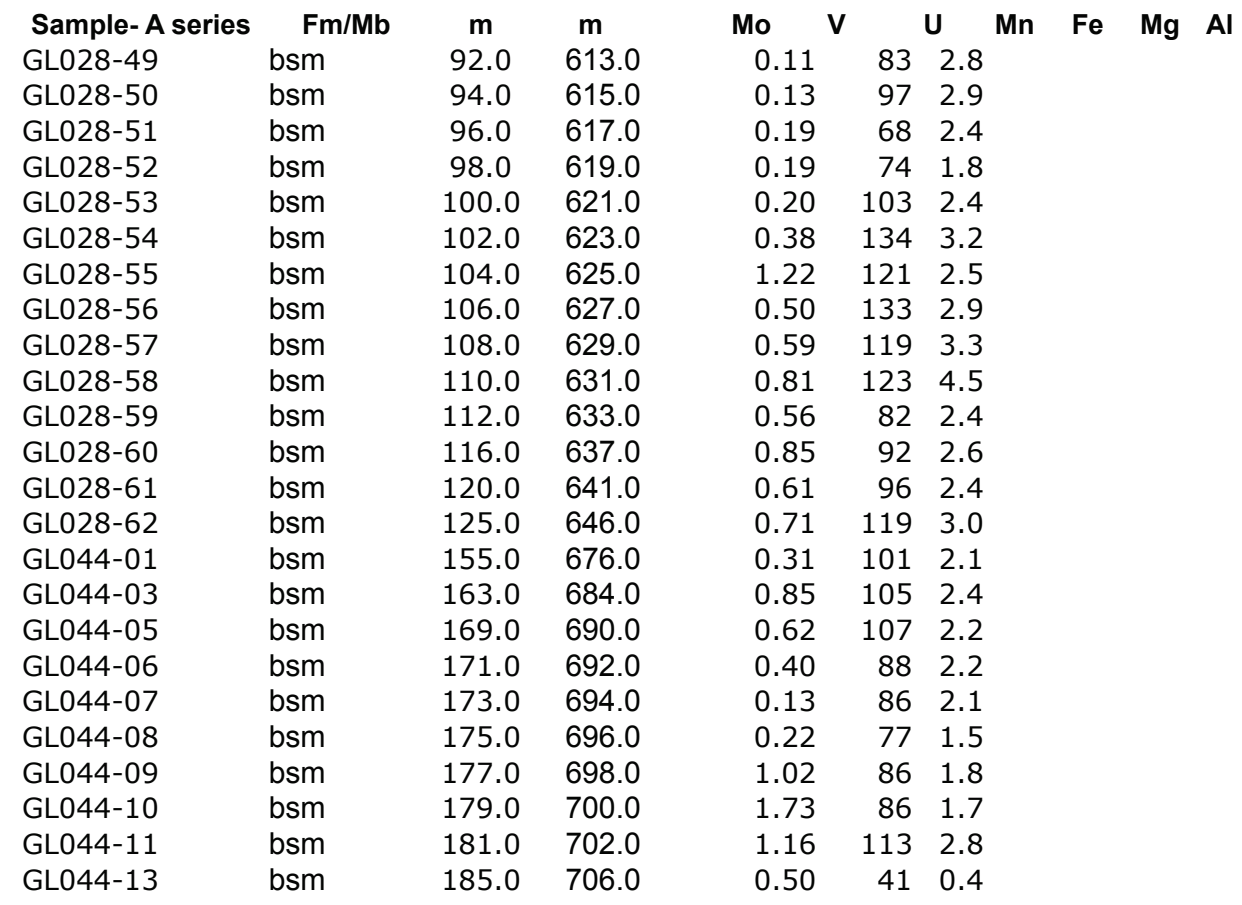




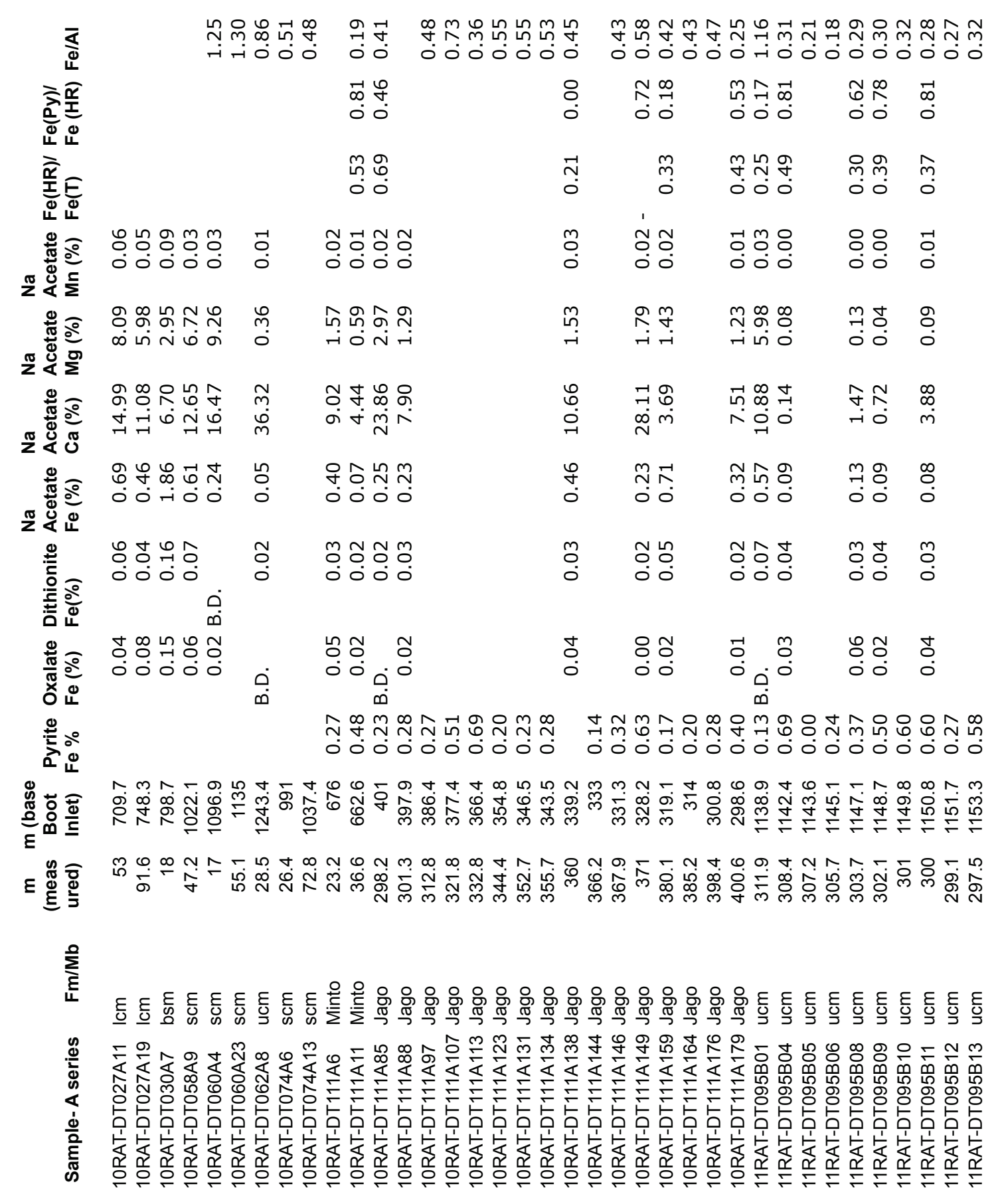




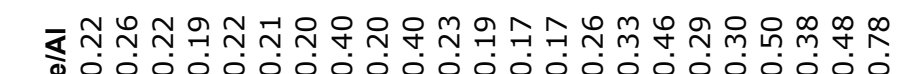

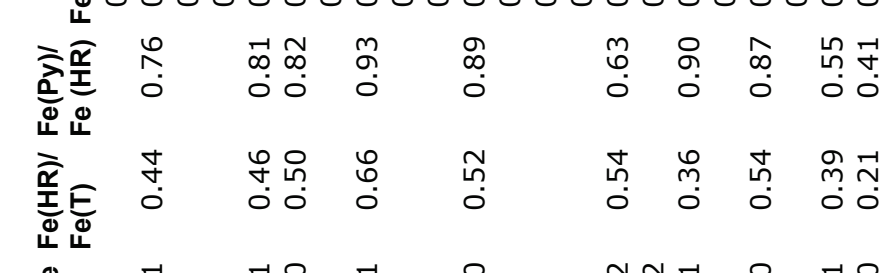

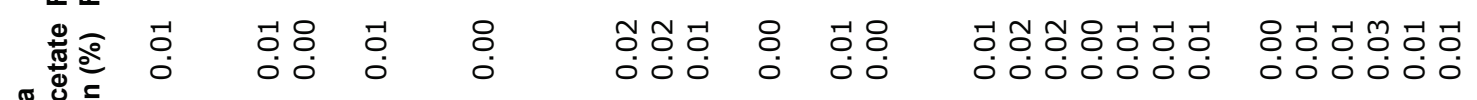

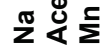

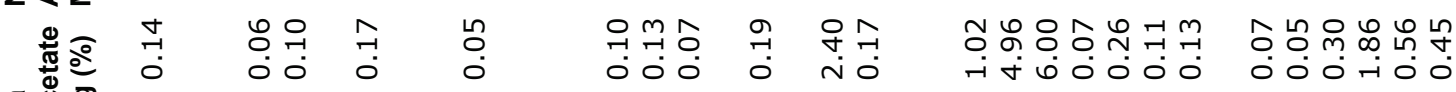

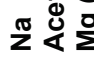

㫕 रष⿺ 丶

声

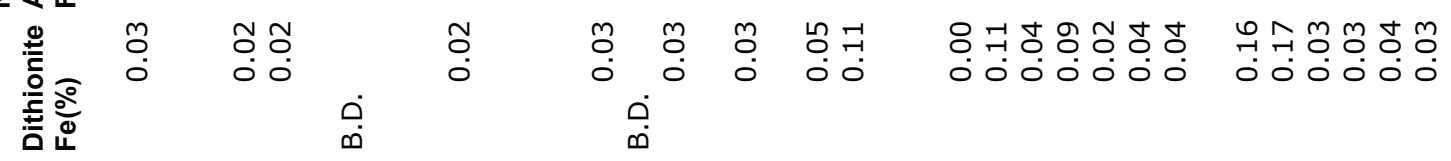

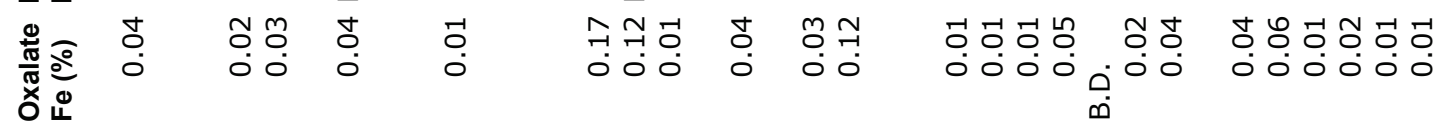

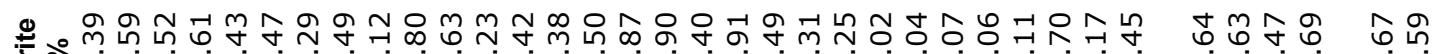

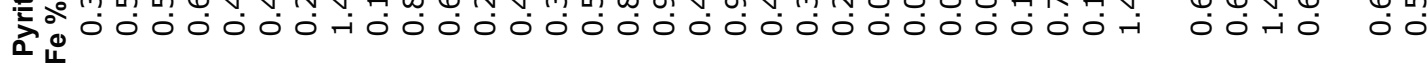

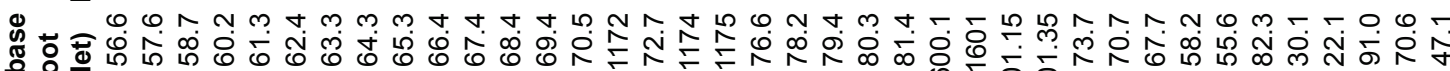

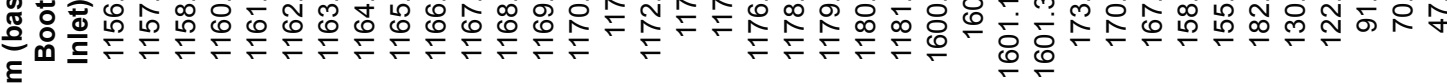

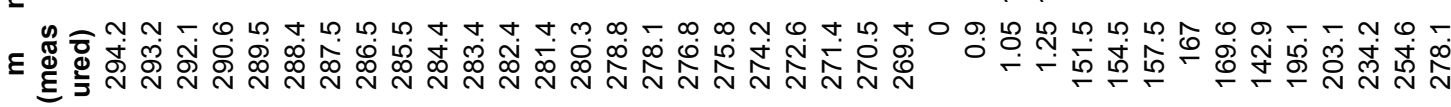

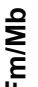

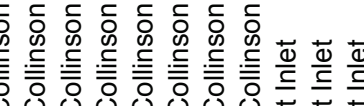

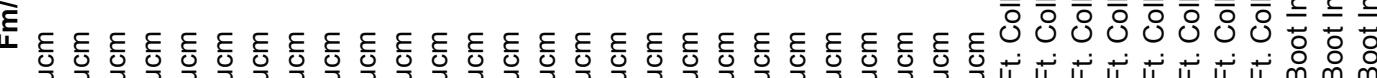

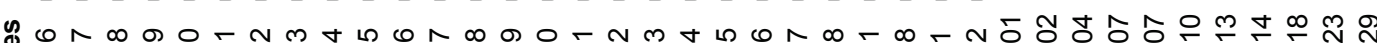

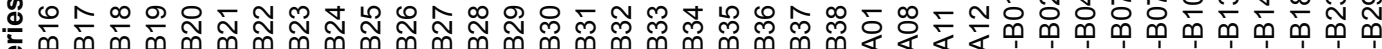

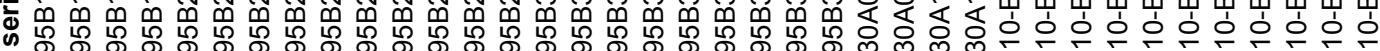
《 0 은 00000 d 5

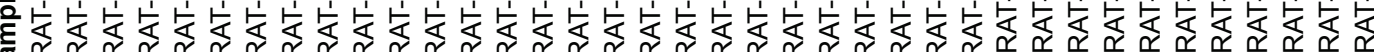
心 


$$
\begin{aligned}
& \text { r. } \\
& \text { 网的 } \\
& \text { 荧 } \\
& \text { 更这去 }
\end{aligned}
$$

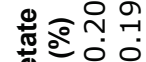

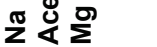

$$
\begin{aligned}
& \text { 密 } \\
& \text { 푷ㅇํㅇ영 } \\
& \text { 든 }
\end{aligned}
$$

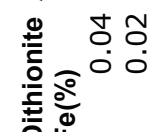

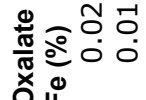

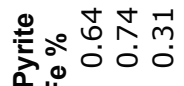

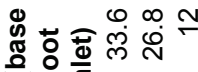

$$
\begin{aligned}
& \varepsilon
\end{aligned}
$$

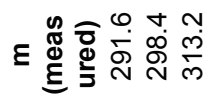

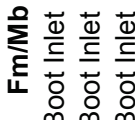

$$
\begin{aligned}
& \text { " ले } \\
& \text { ब ल } \\
& \text { 은은 응 } \\
& \text { 《돌단 } \\
& \text { d。 } \\
& \text { 类这客 }
\end{aligned}
$$




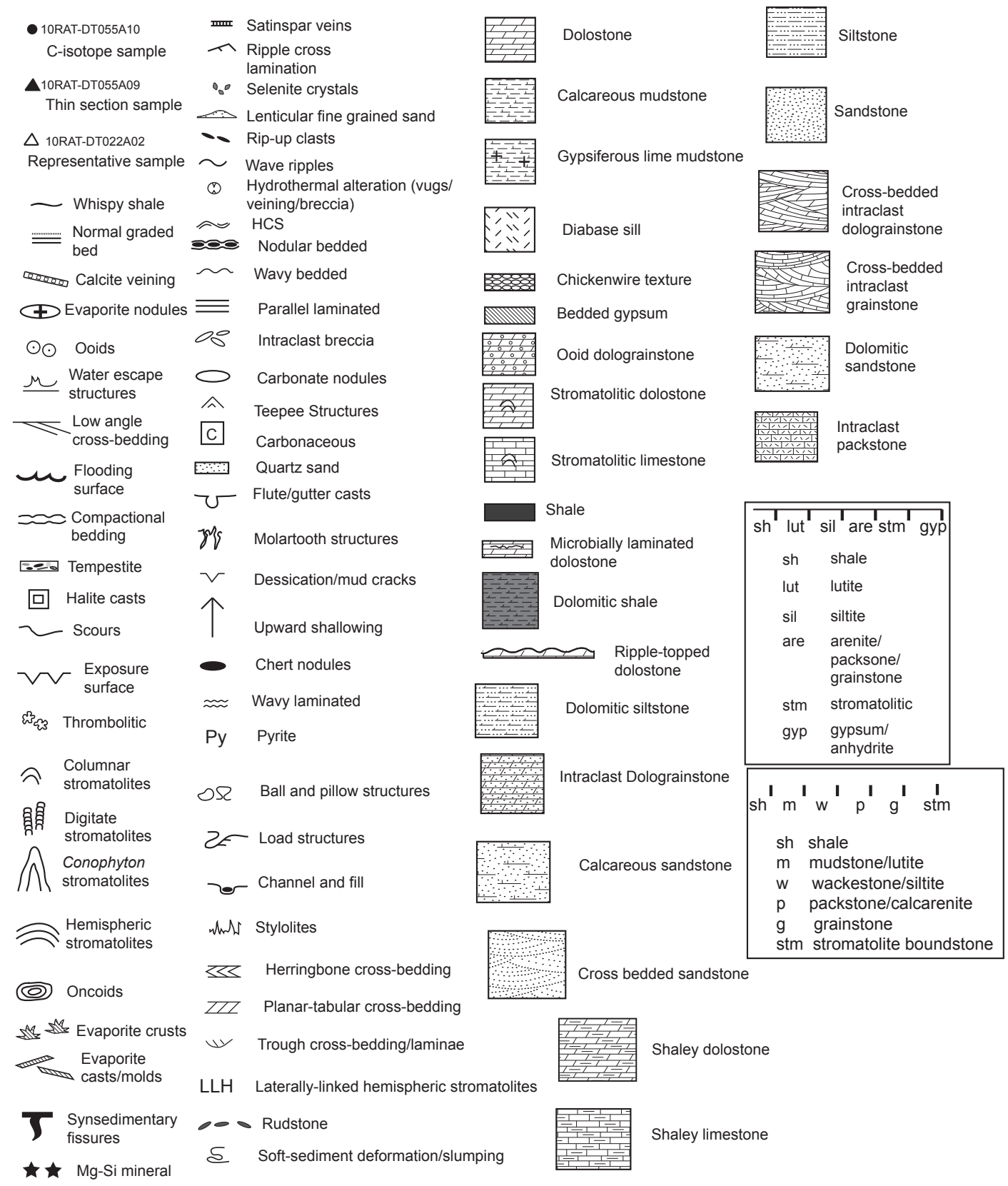

\section{Appendix 5 Legend for measured stratigraphic sections}



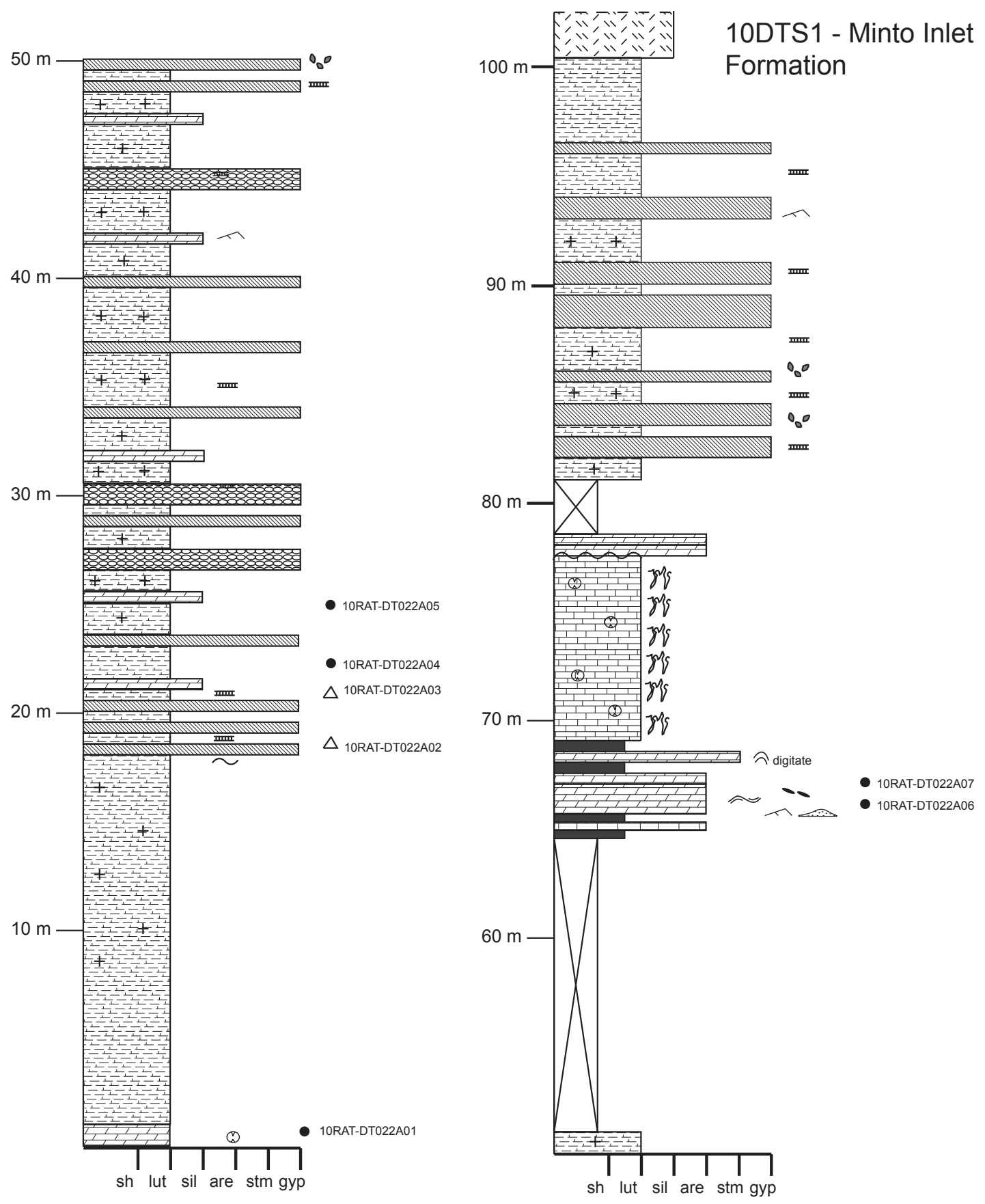

Appendix 6 10DTS1, Minto Inlet Formation 


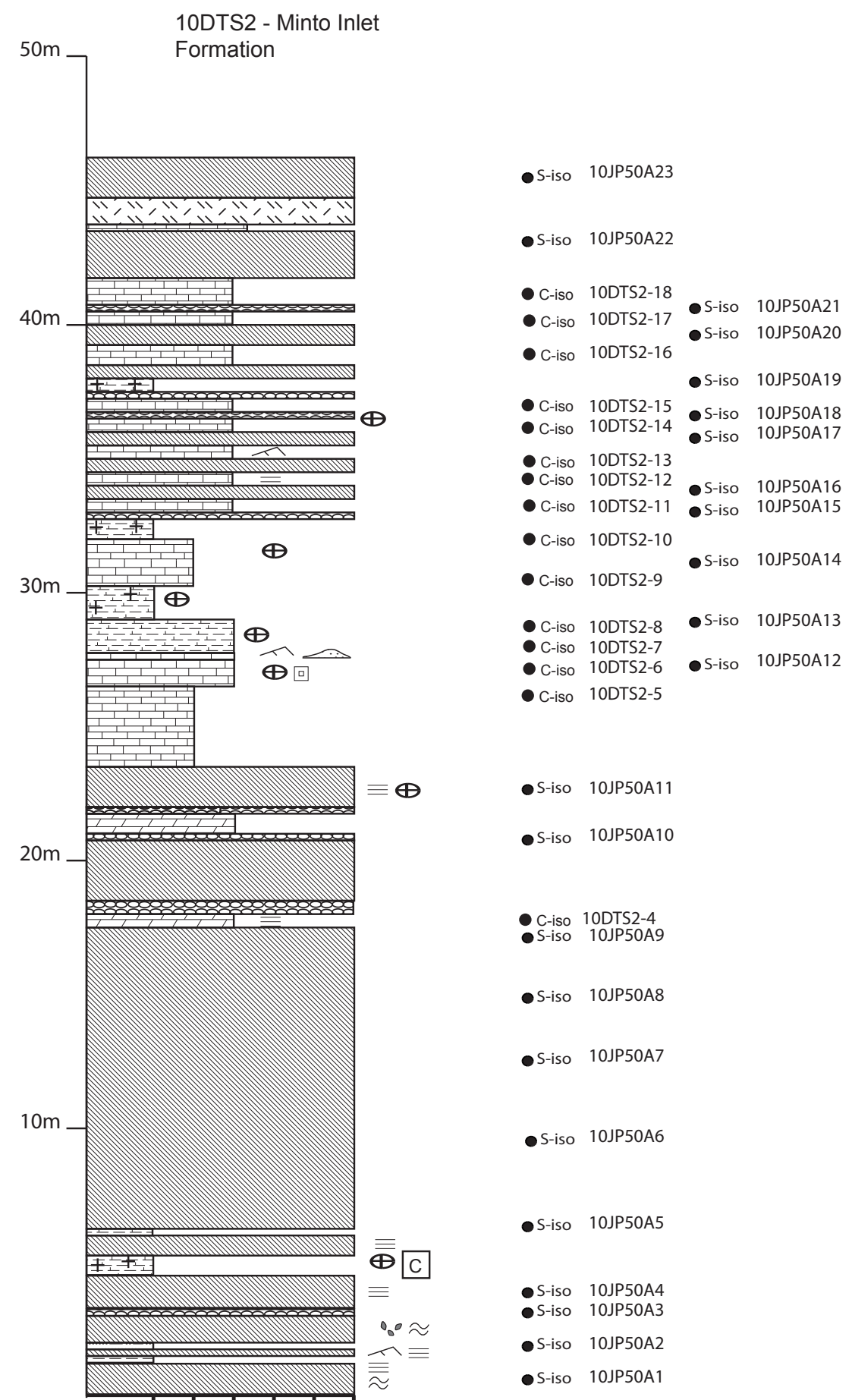

sh lut sil are stm gyp

Appendix 7 10DTS2, Minto Inlet Formation 


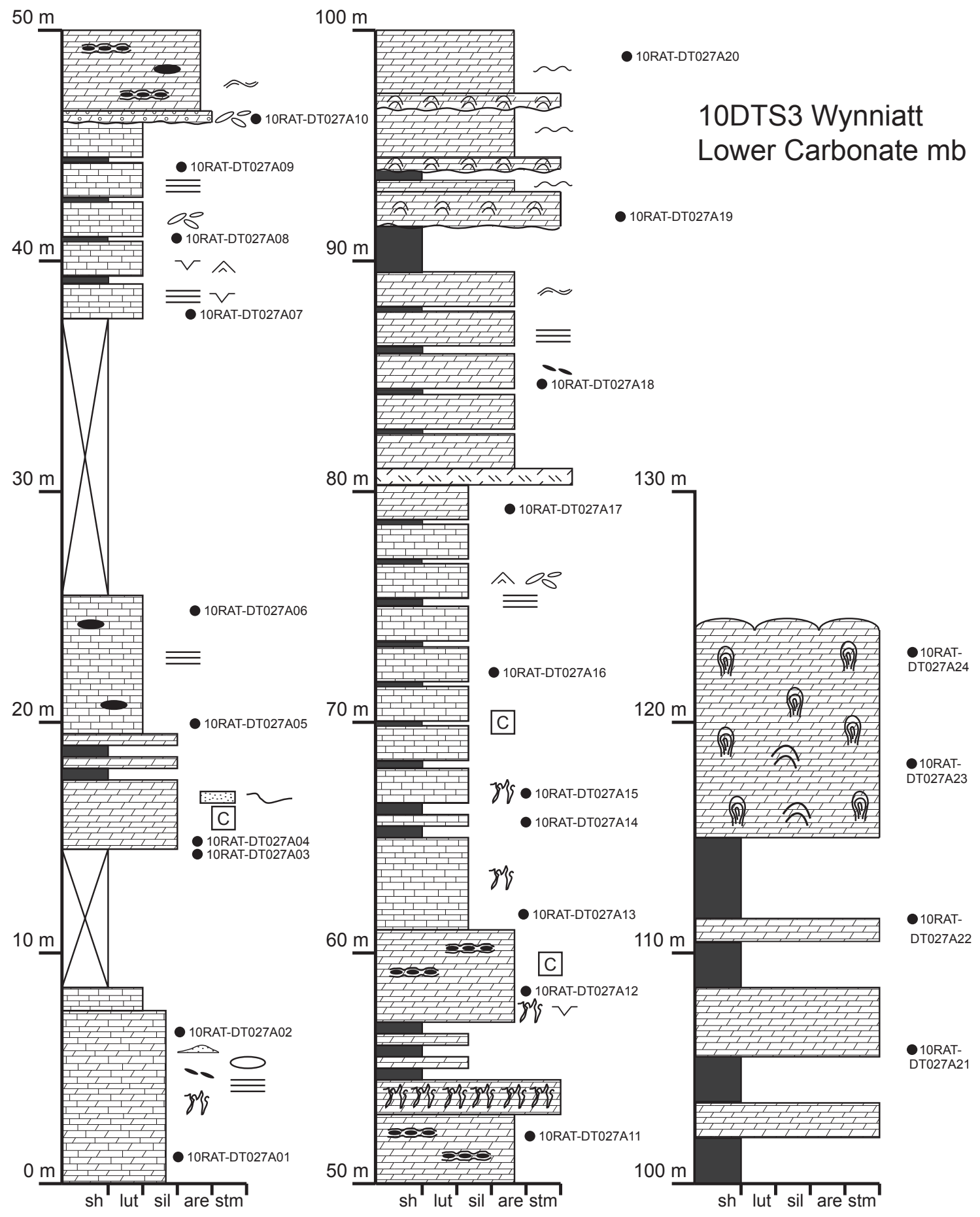

Appendix 8 10DTS3, Lower Carbonate member 


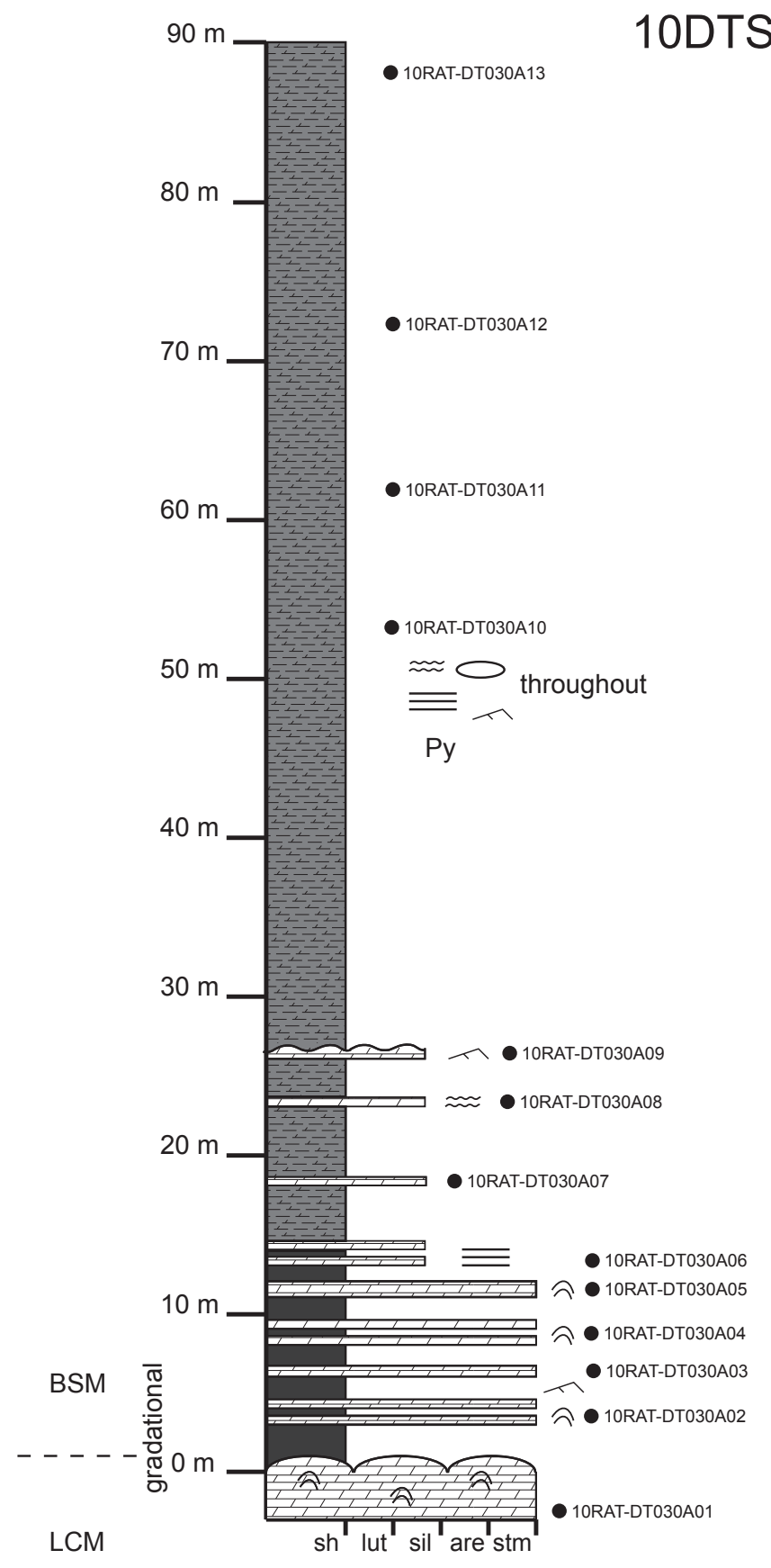

\section{DTS4a - Wynniatt, Black Shale member}

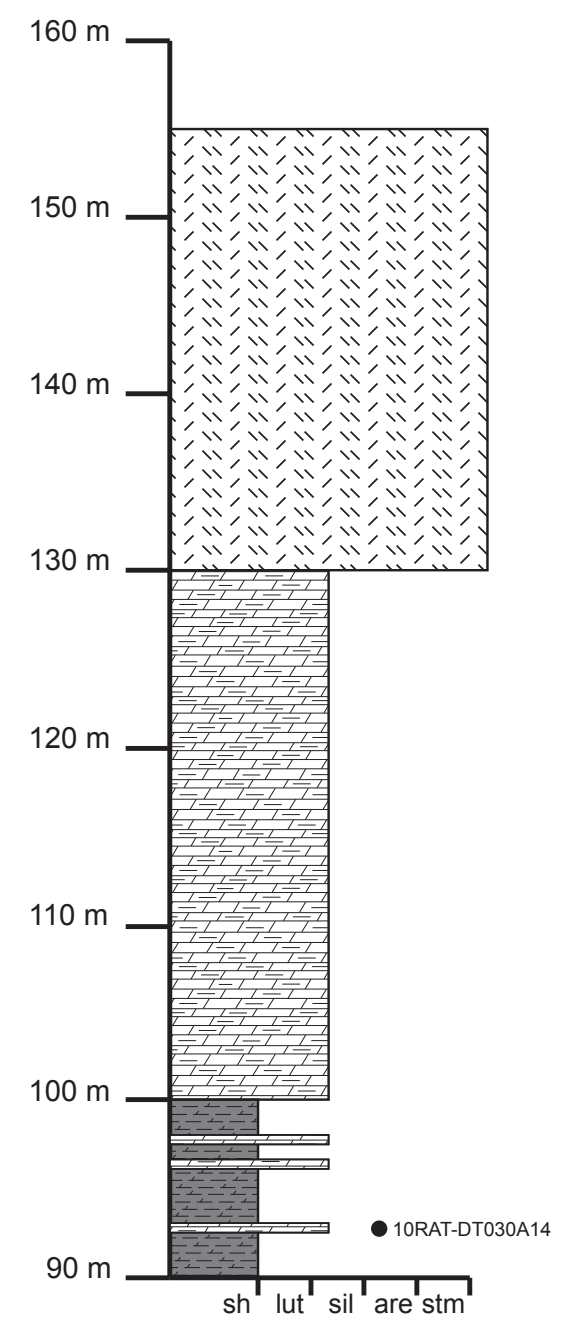

Appendix 9 10DTS4a, Black Shale member 


\section{DTS4b - Wynniatt, black shale member}

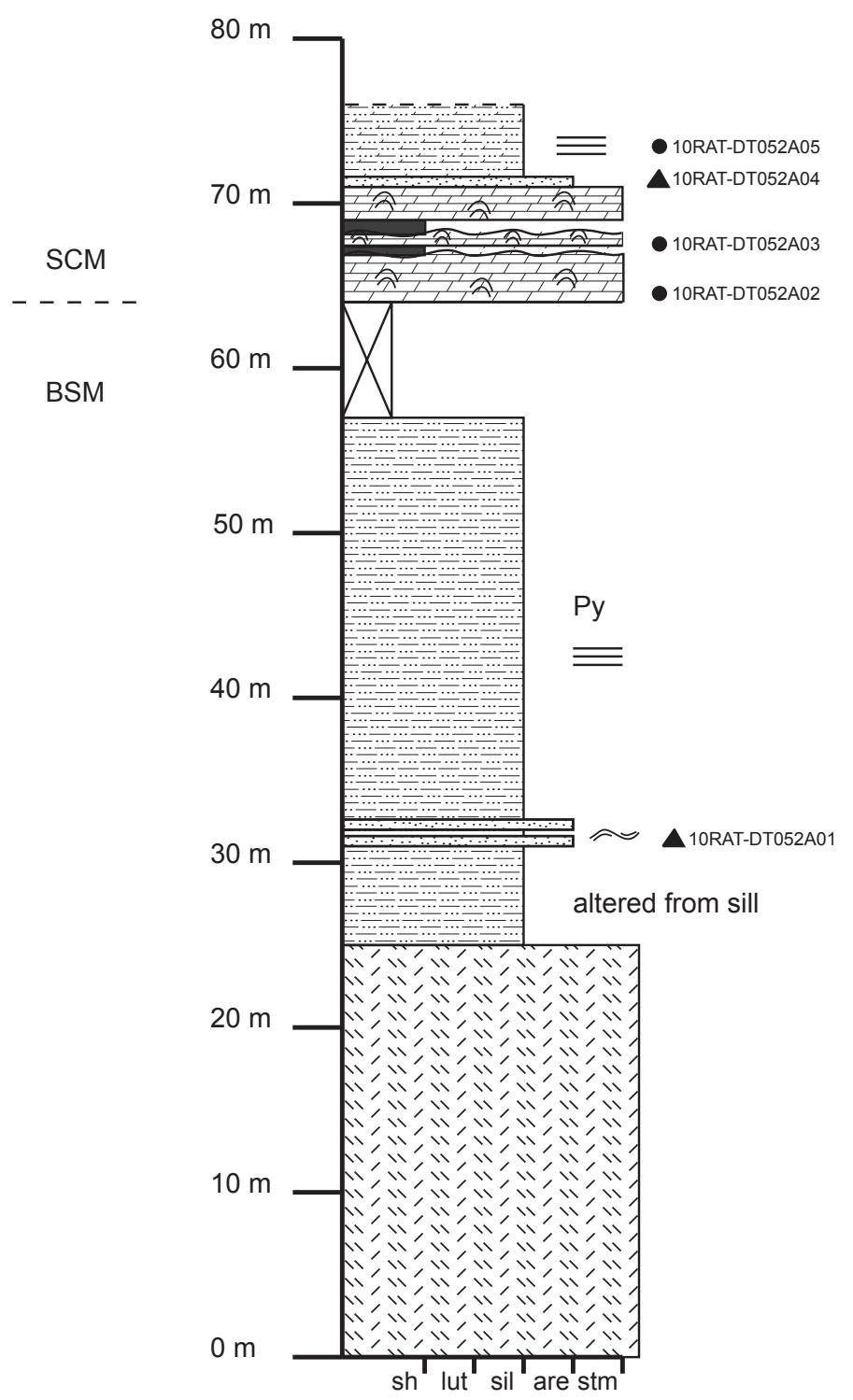

Appendix 10 10DTS4b, Black Shale member 


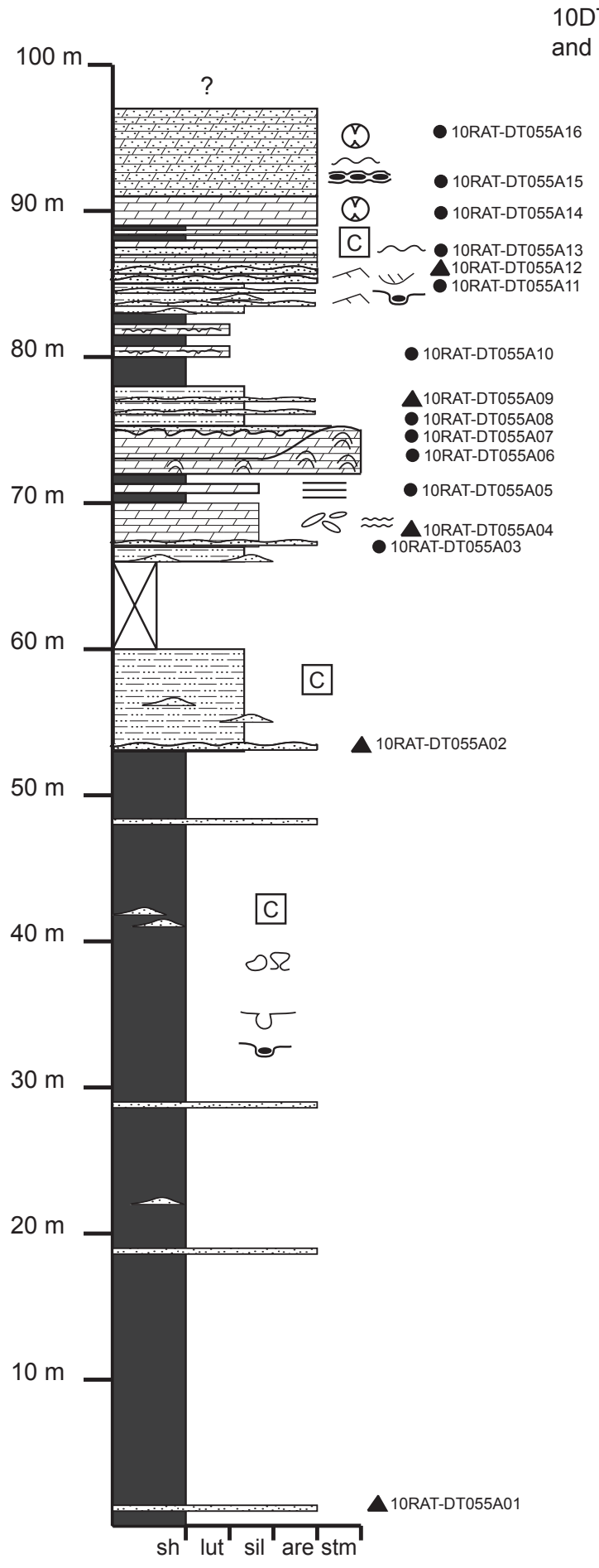

Appendix 11 10DTS5, Black Shale and Stromatolitic Carbonate members 


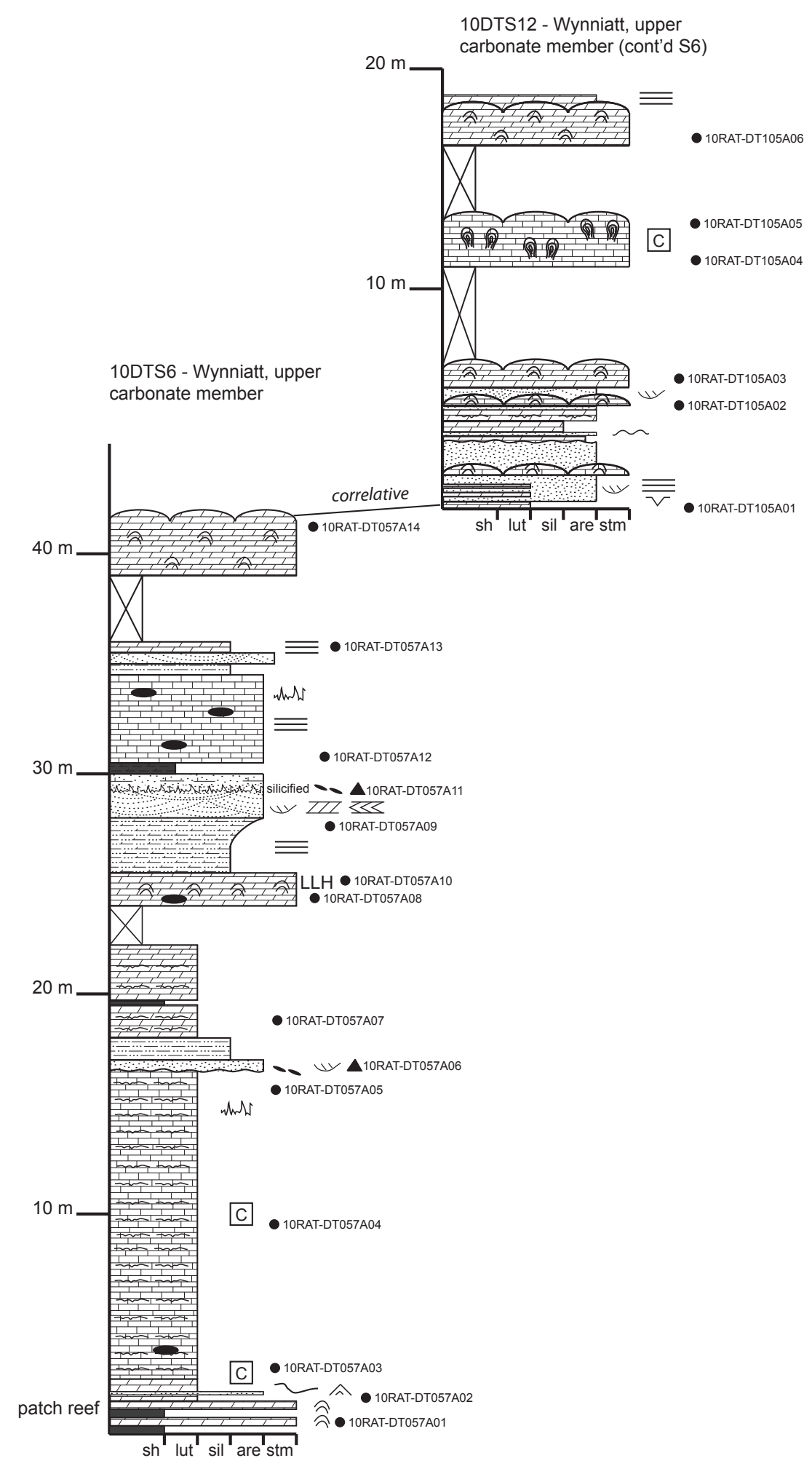

Appendix 12 10DTS6 and 10DTS12, Upper Carbonate member 
10DTS7 - Wynnaitt, stromatolitic carbonate member

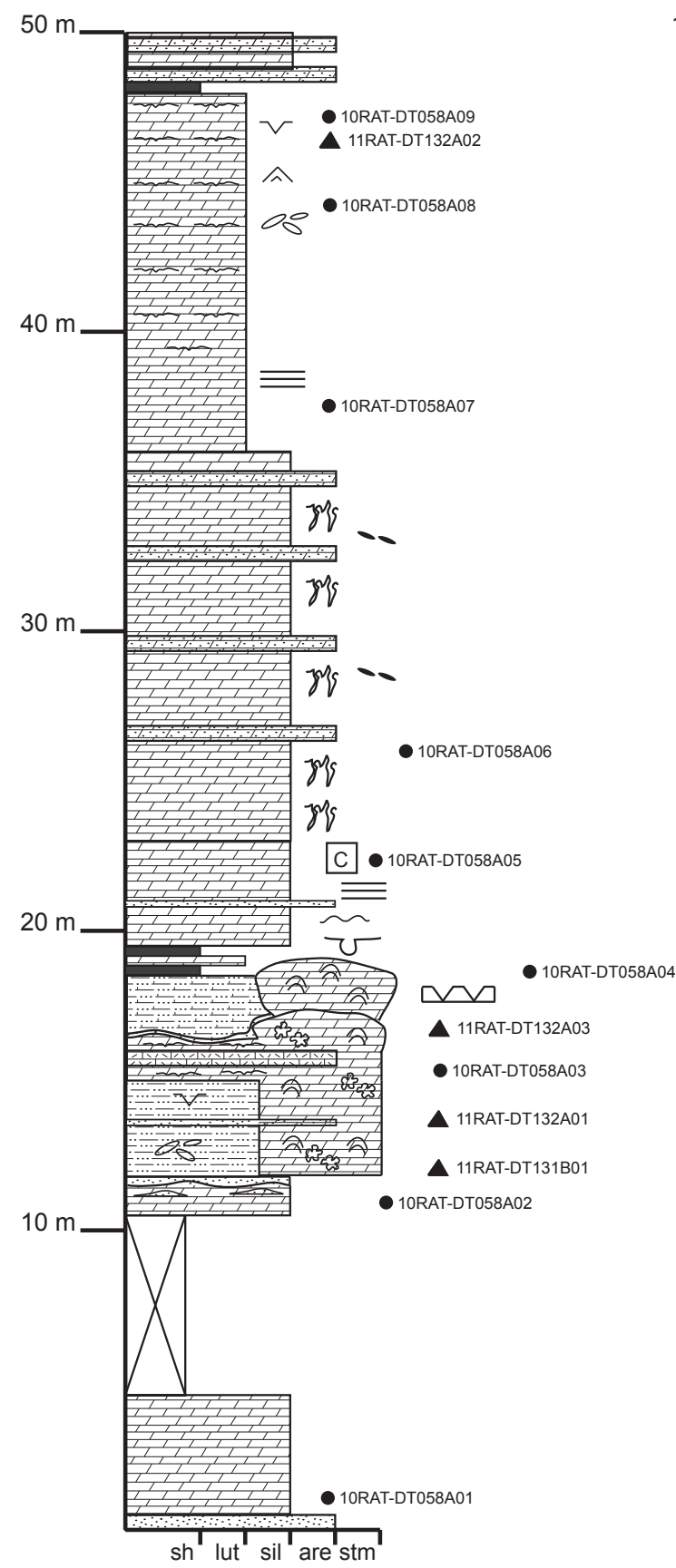

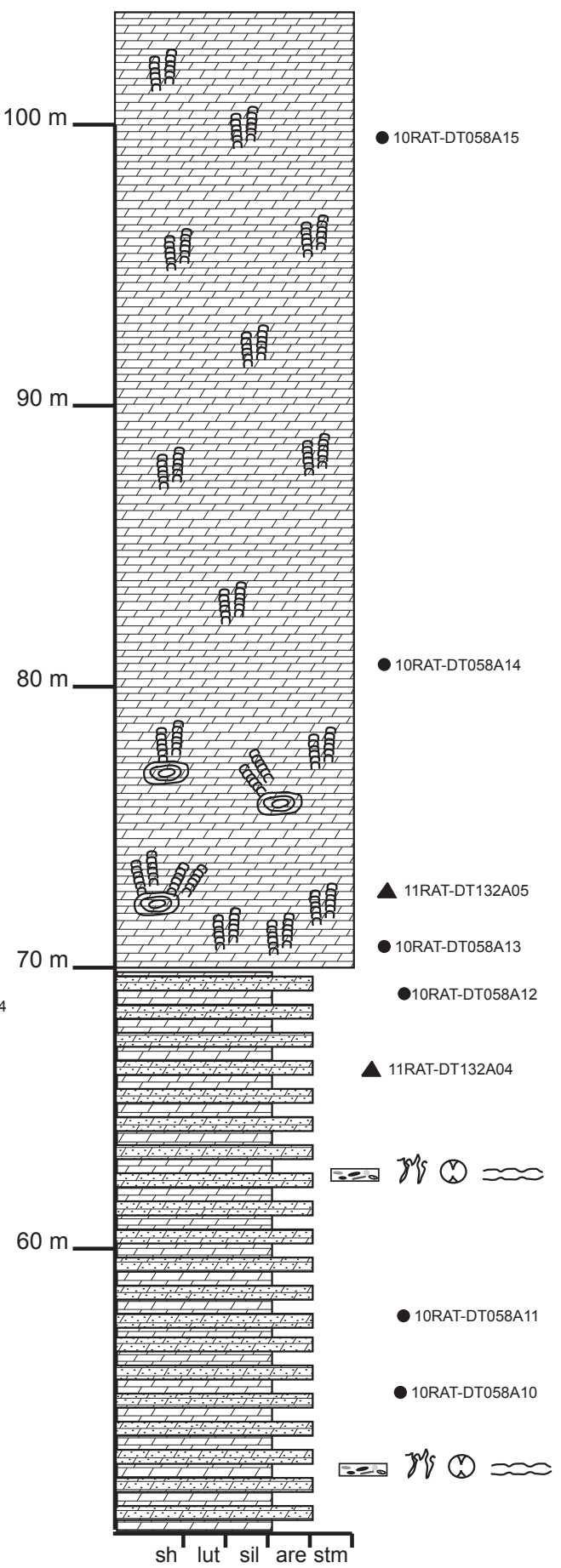

Appendix 13 10DTS7, Stromatolitic Carbonate member 


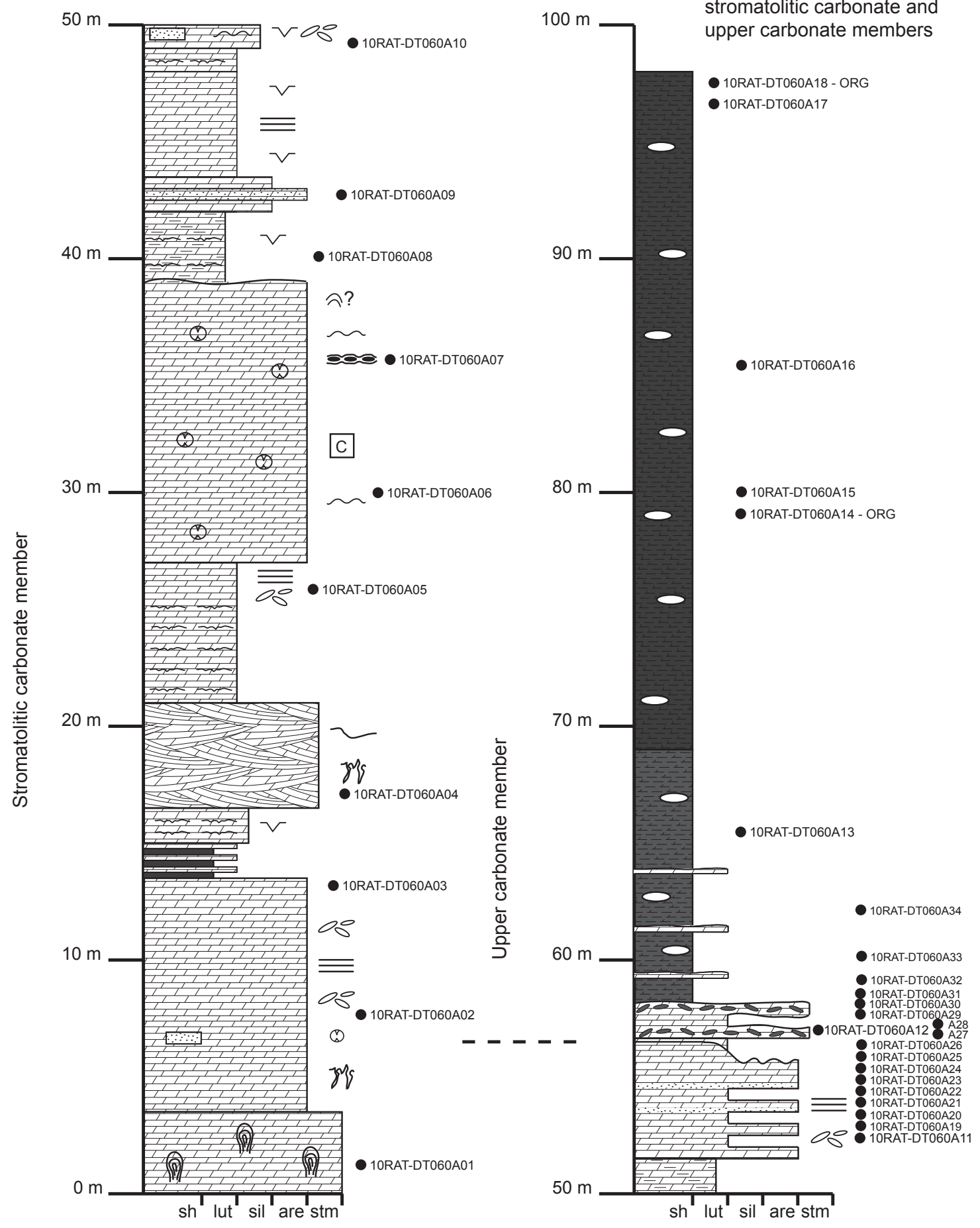

Appendix 14 10DTS8, Stromatolitic Carbonate and Upper Carbonate members 


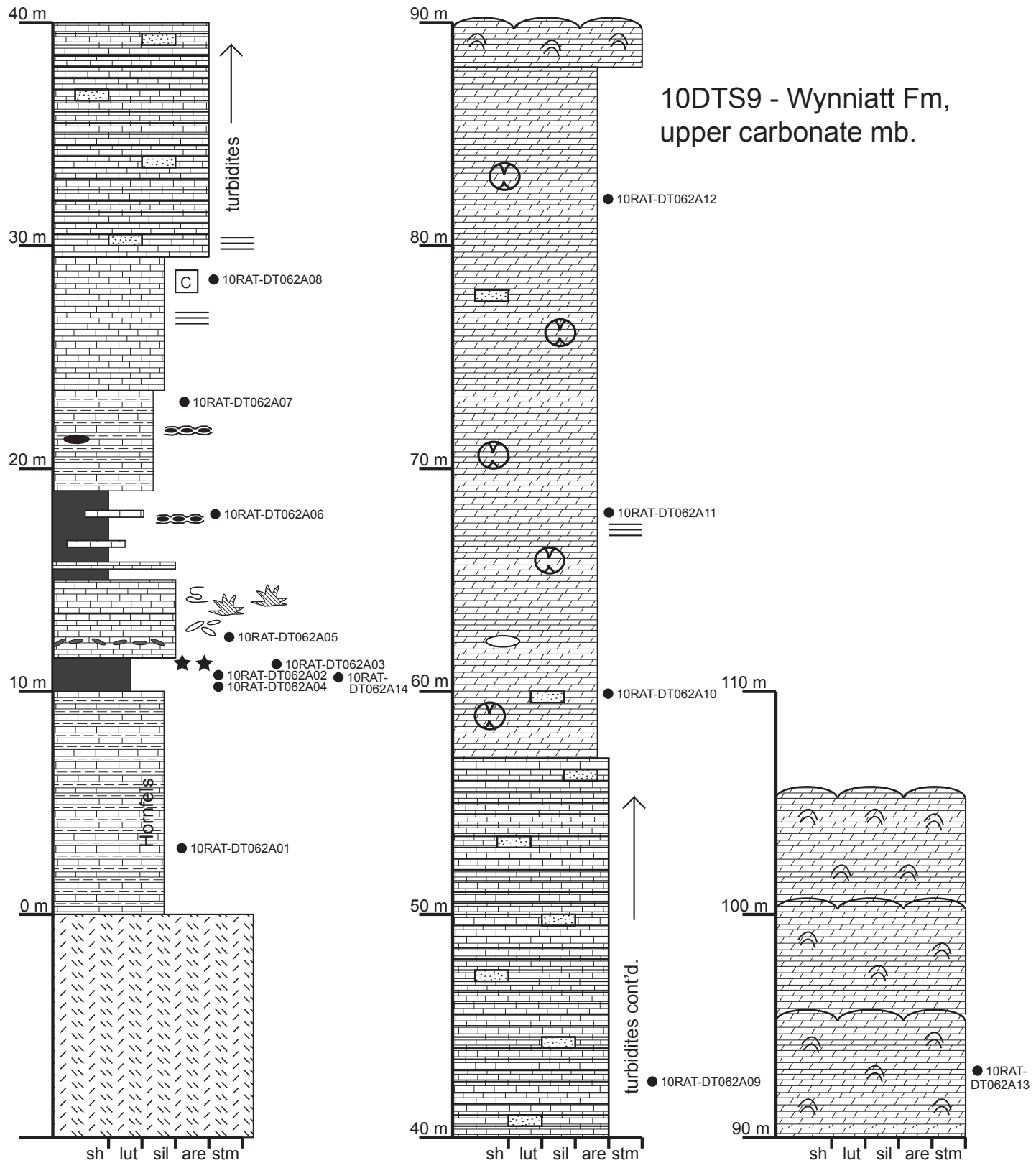

Appendix 15 10DTS9, Upper Carbonate member 


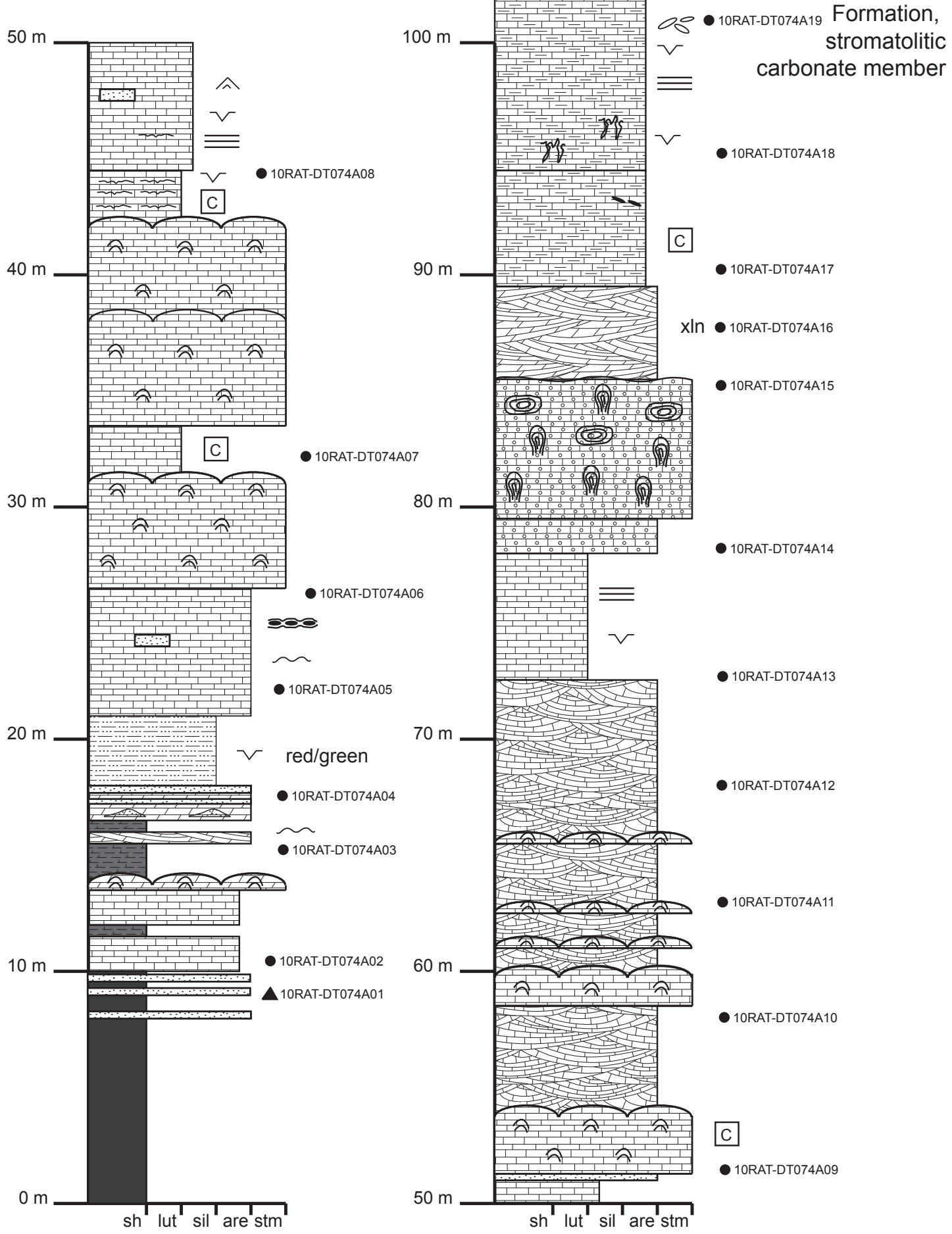

Appendix 16 10DTS10, Stromatolitic Carbonate member 


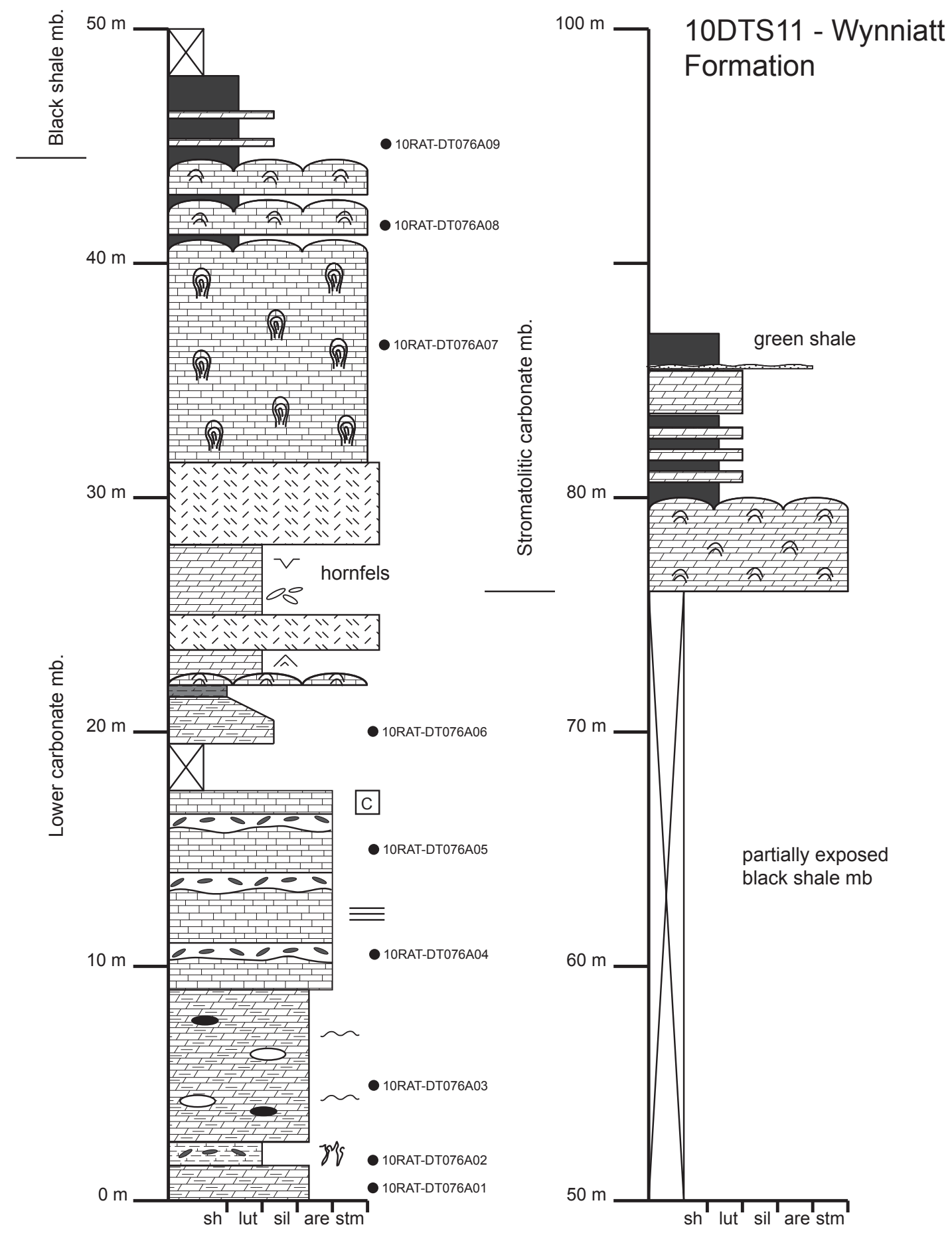

Appendix 17 10DTS11, Lower Carbonate and Black Shale members 


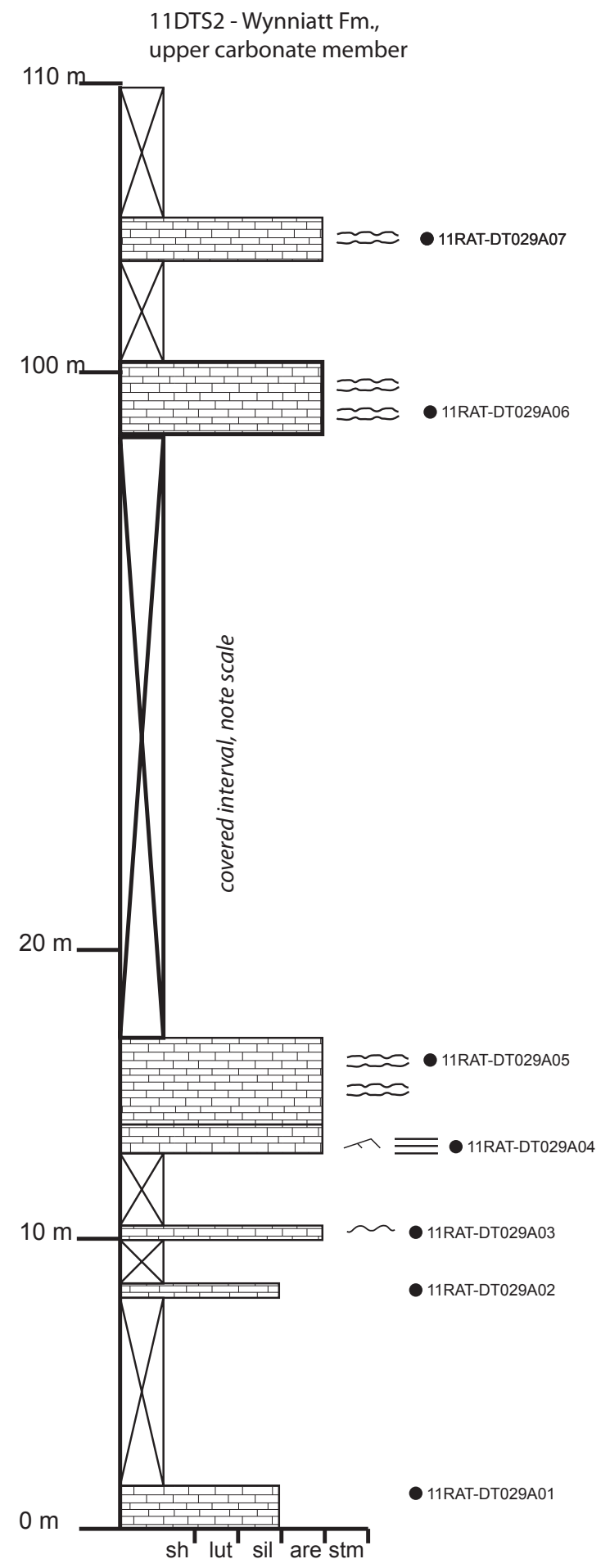

Appendix 18 11DTS2, Upper Carbonate member 


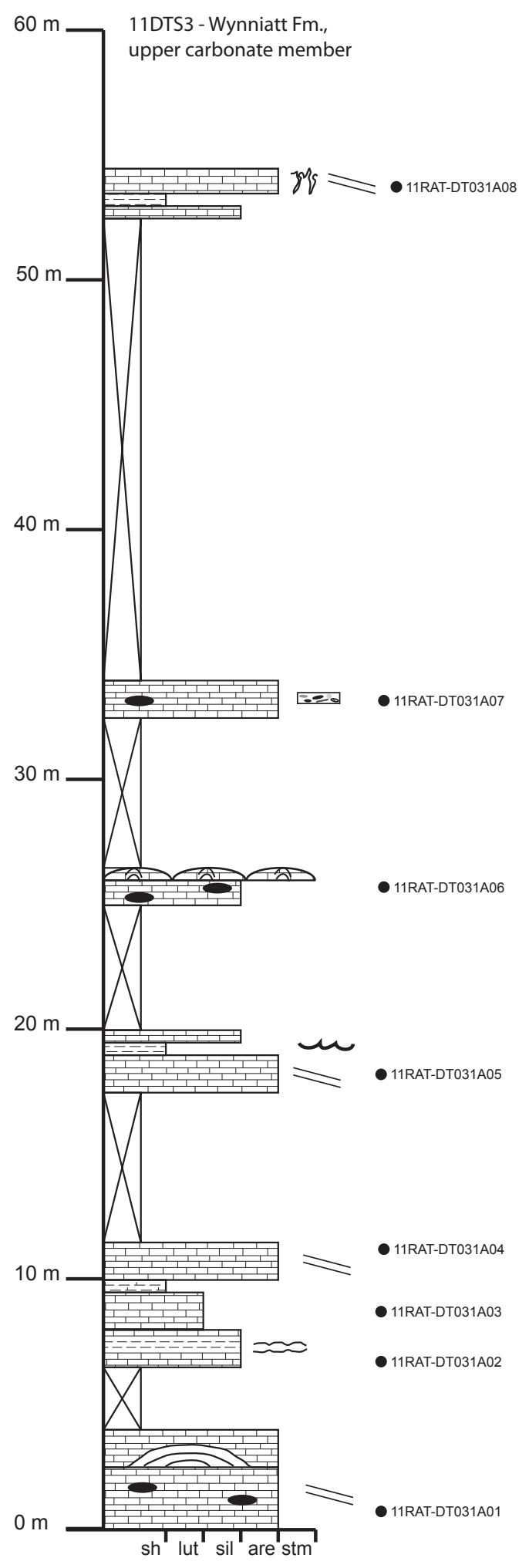

Appendix 19 10DTS3, Upper Carbonate member 


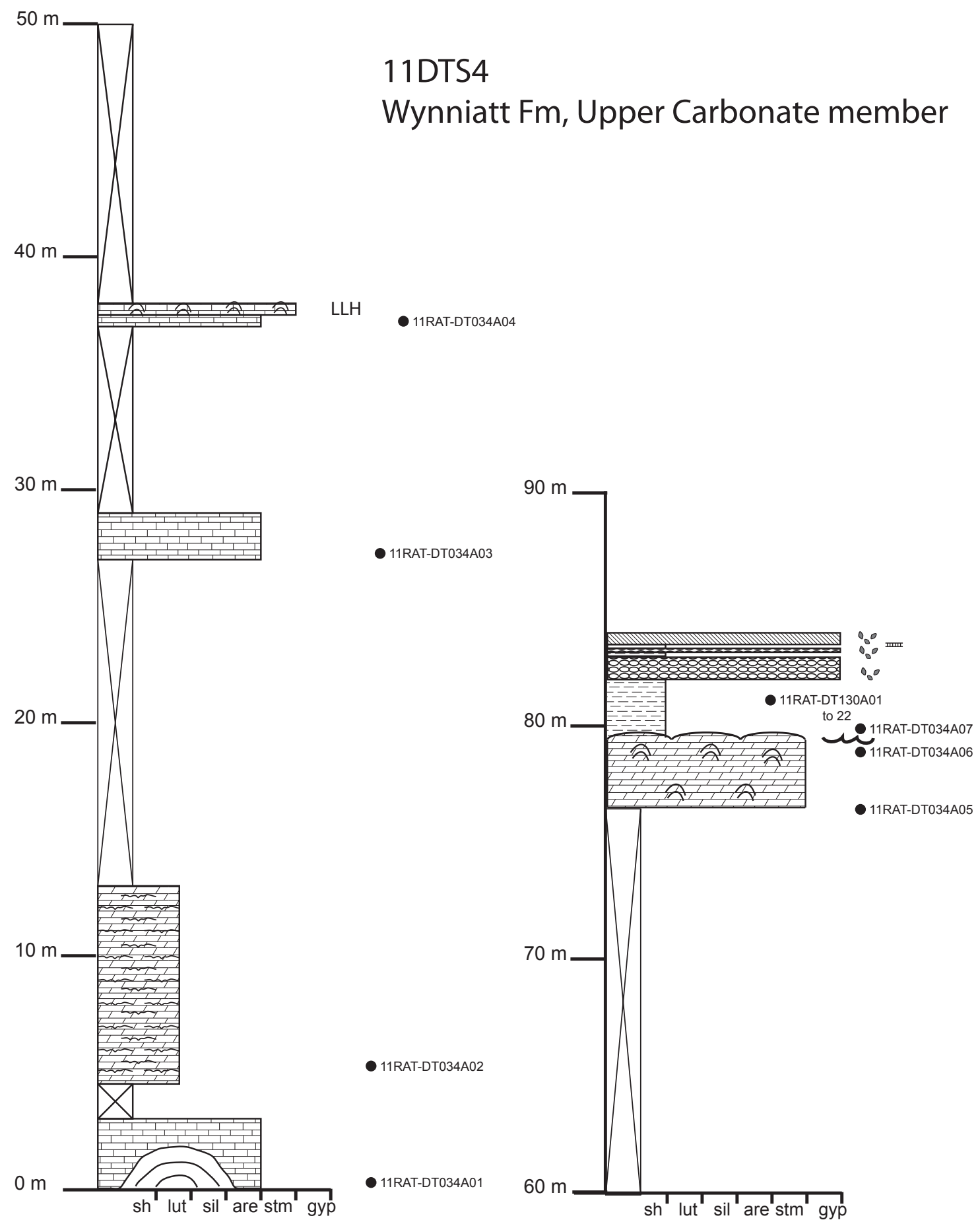

Appendix 20 11DTS4, Upper Carbonate member 


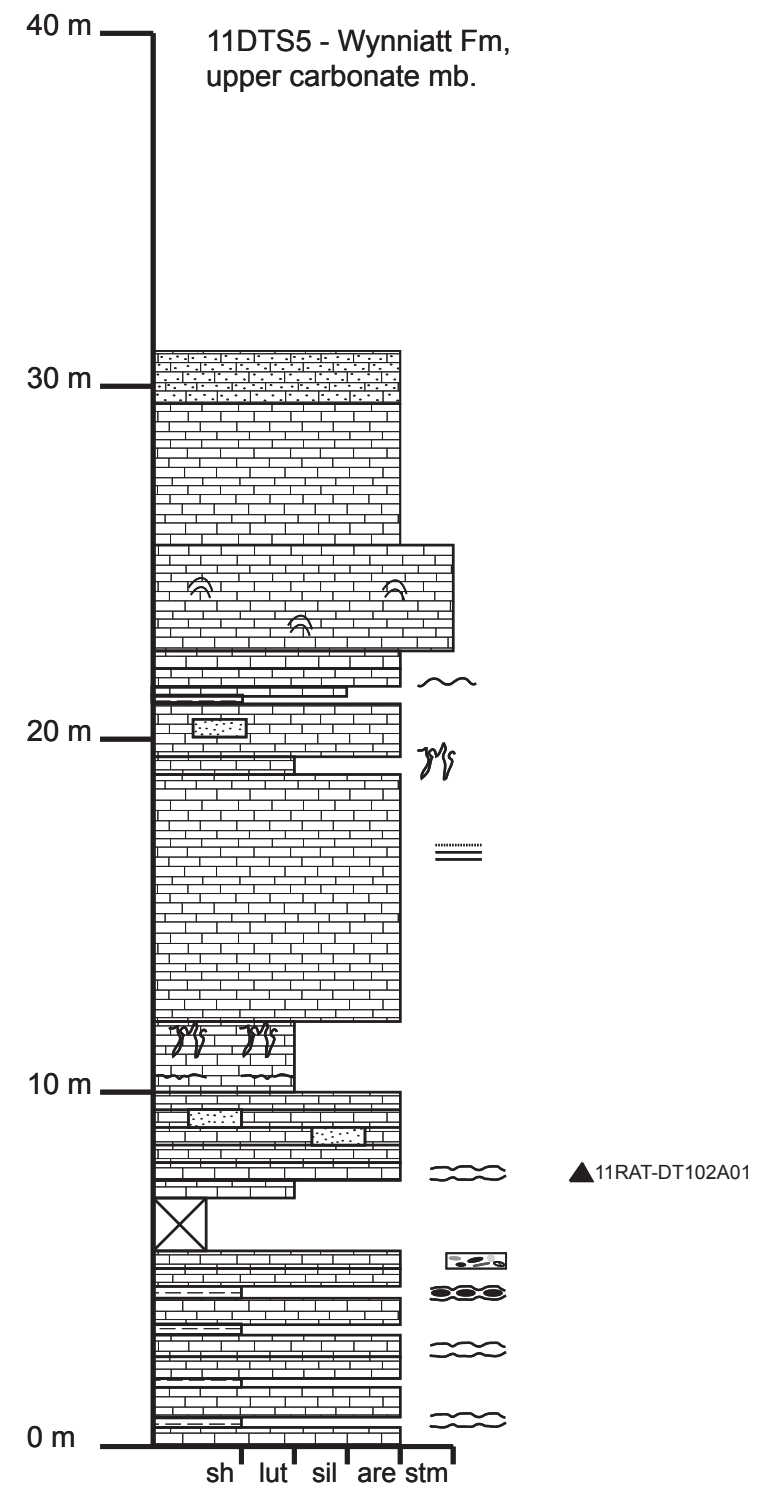

Appendix 21 11DTS5, Upper Carbonate member 


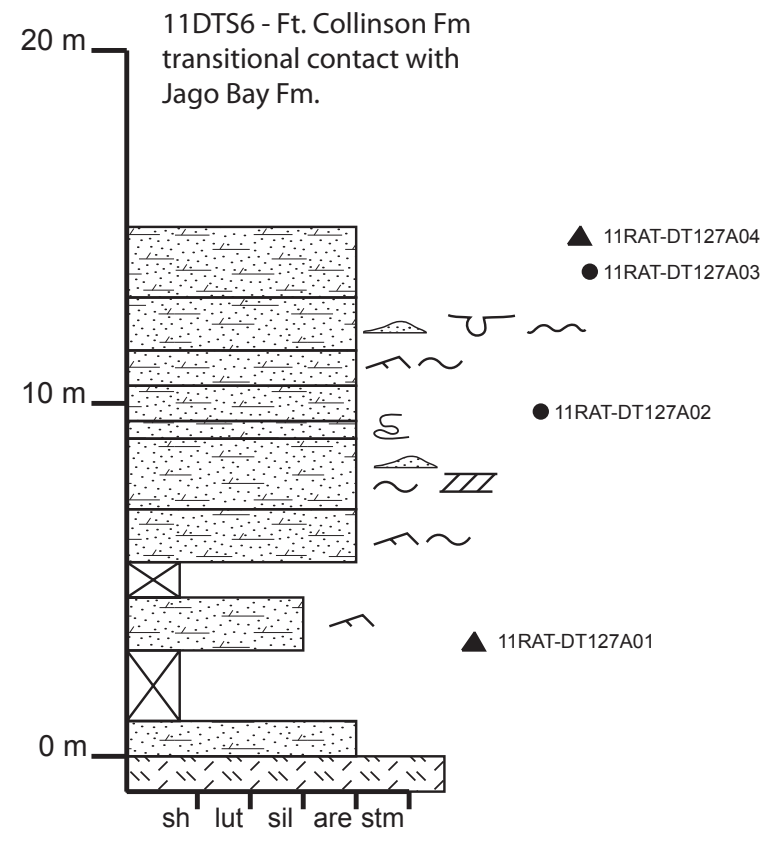

Appendix 22 11DTS6, Fort Collinson Formation 


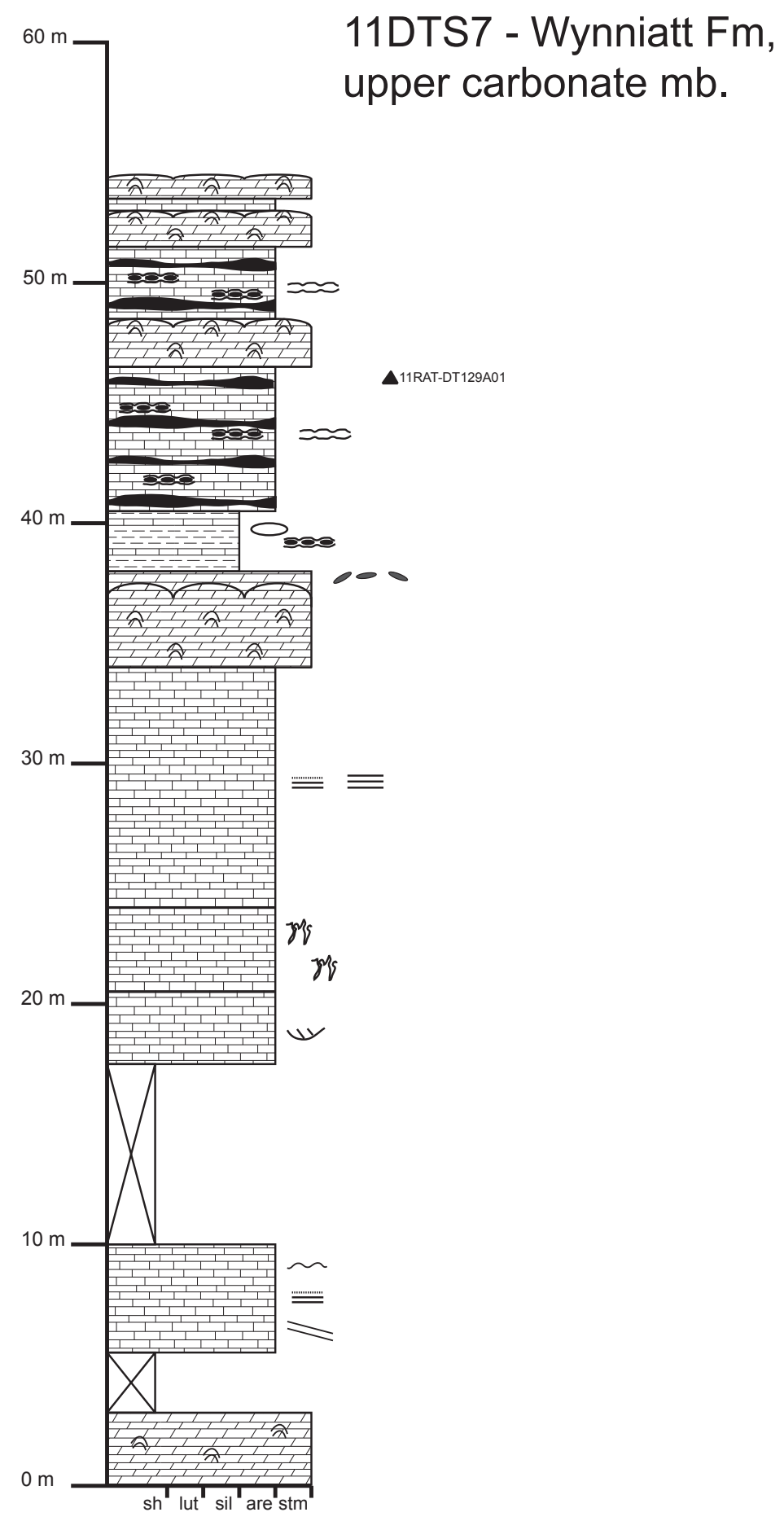

Appendix 23 11DTS7, Upper Carbonate member 


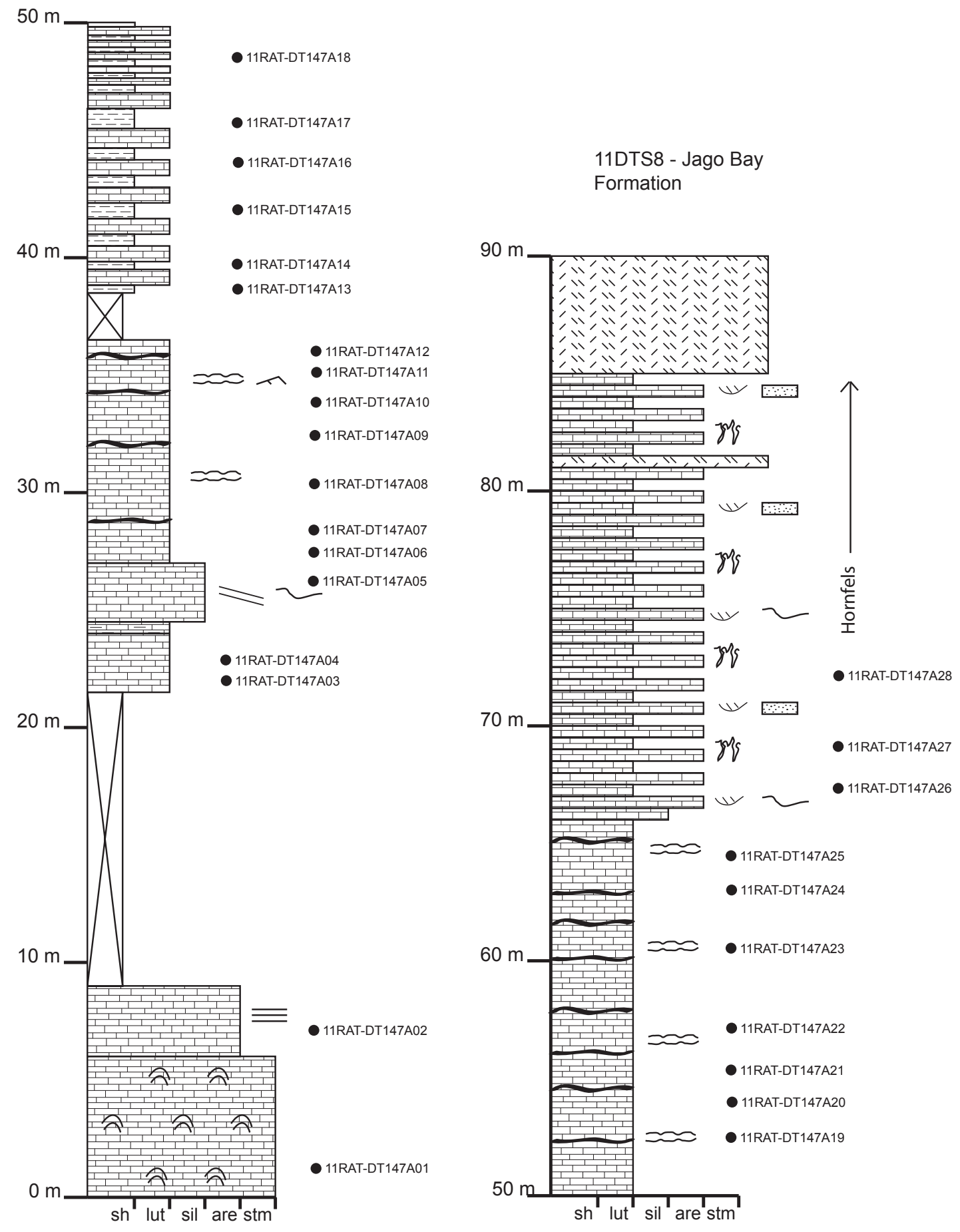

Appendix 24 11DTS8, Jago Bay Formation 

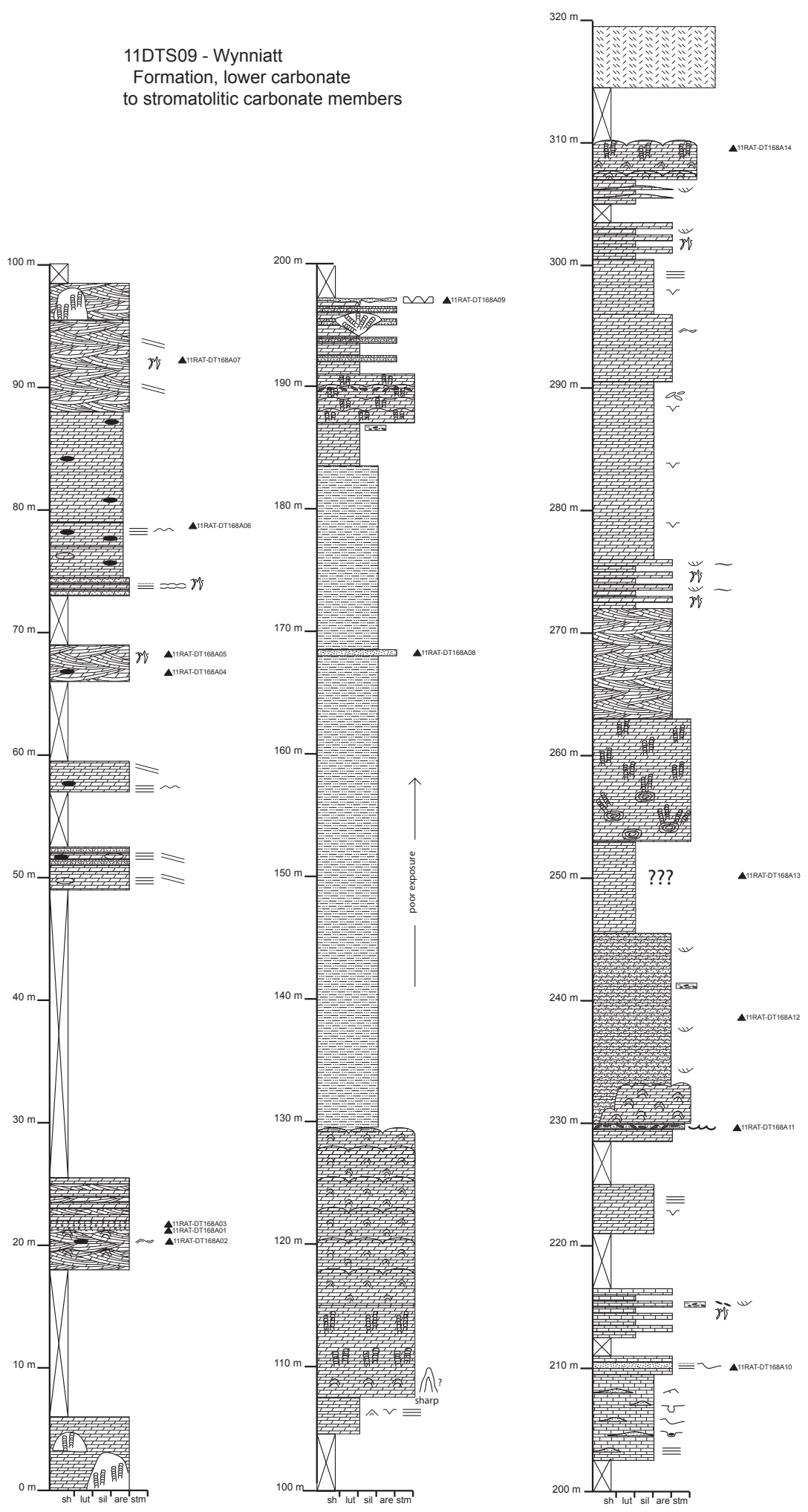

Appendix 25 11DTS9; Lower Carbonate, Black Shale, and Stromatolitic Carbonate members 


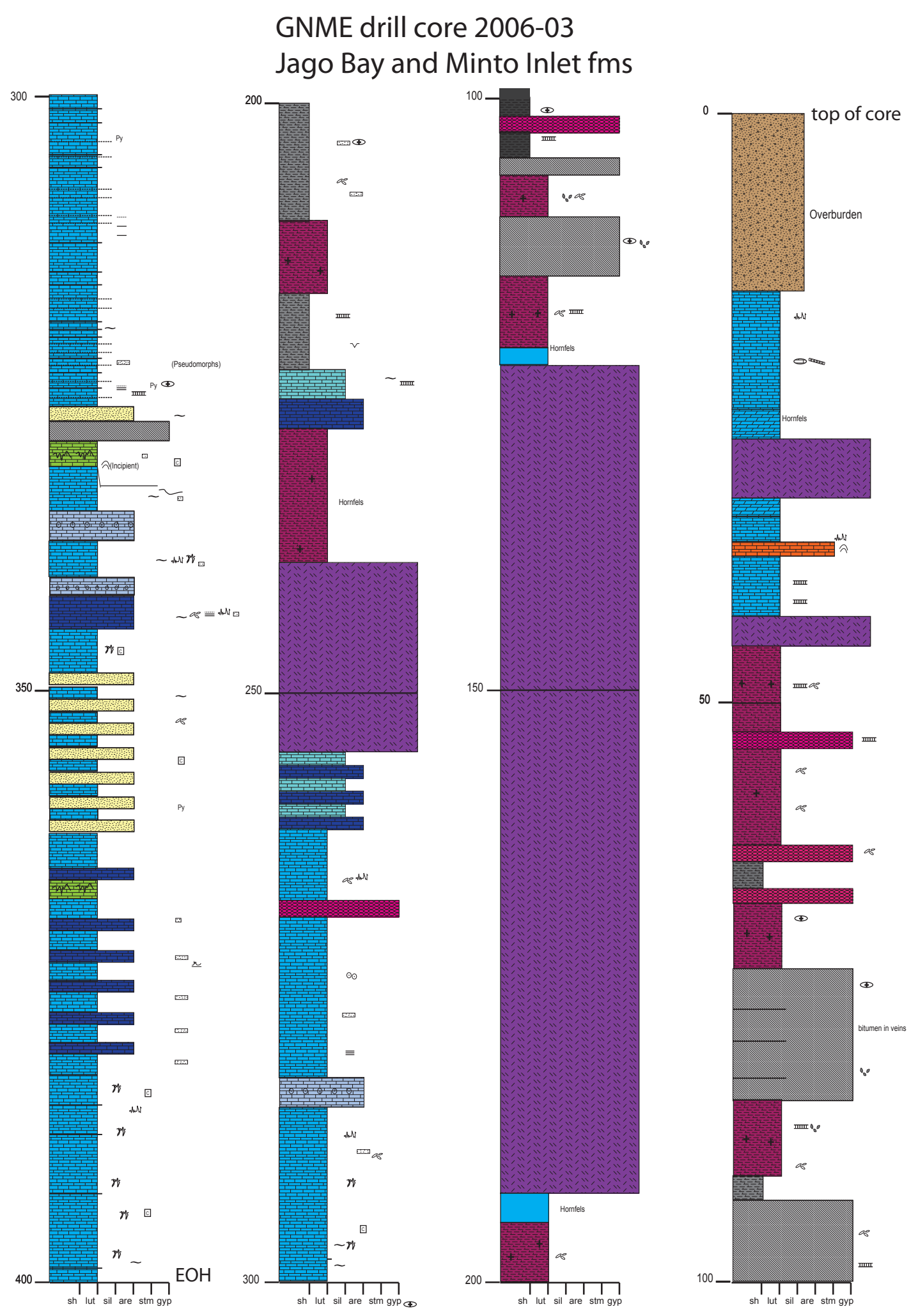

Appendix 26 GNME drill core 06-03, Jago Bay and Minto Inlet formations 


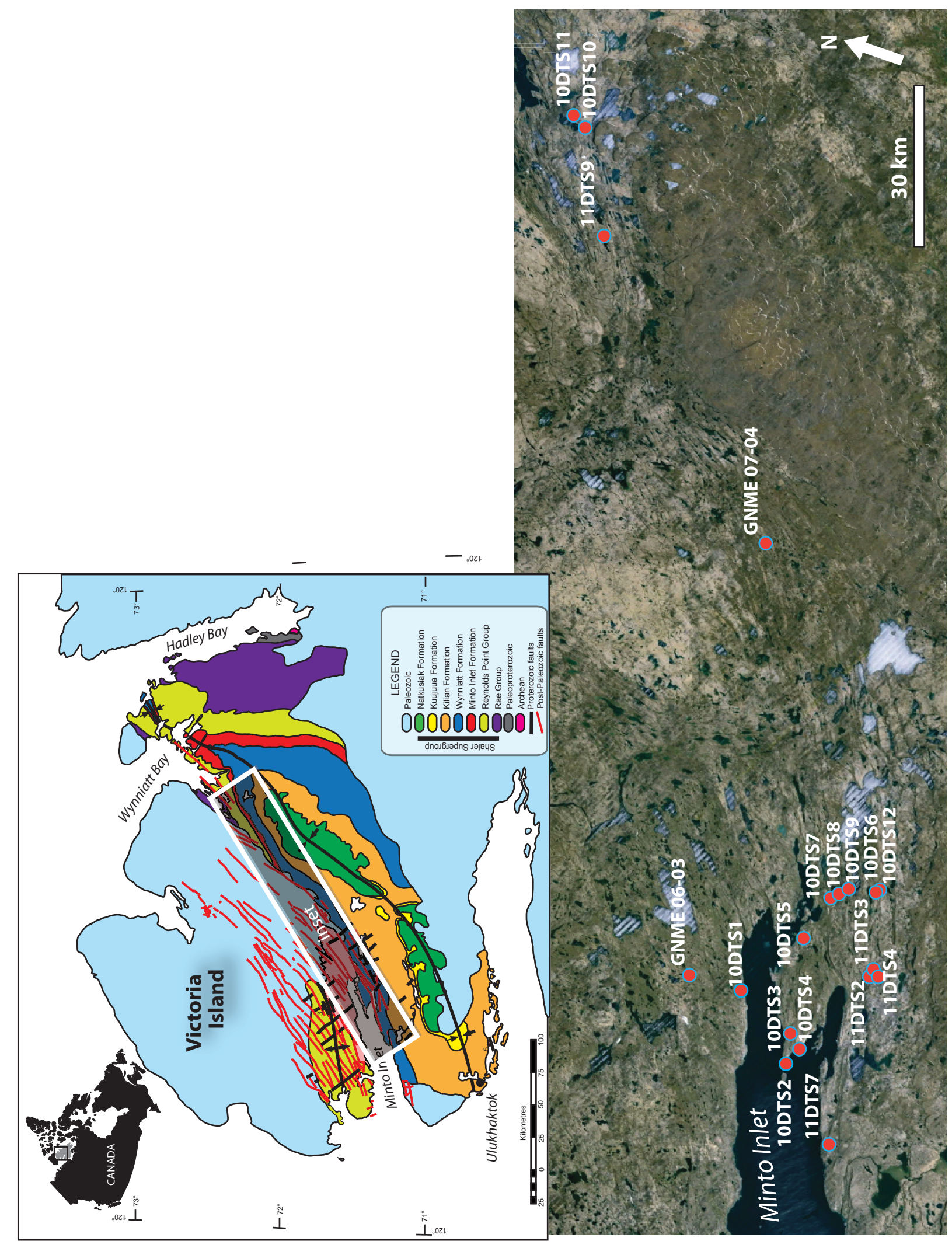

Appendix 27 Section location map 